\title{
ESTUDO COMPARADO DOS SISTEMAS DE SEGURIDADE SOCIAL DO JAPÃO E DO BRASIL: A PROTEÇÃO AOS TRABALHADORES DE AMBOS OS PAÍSES
}

\author{
Dissertação de Mestrado
}

Orientador: Professor Doutor Masato Ninomiya

Faculdade de Direito da Universidade de São Paulo

São Paulo

2014 


\title{
ESTUDO COMPARADO DOS SISTEMAS DE SEGURIDADE SOCIAL DO JAPÃO E DO BRASIL: A PROTEÇÃO AOS TRABALHADORES DE AMBOS OS PAÍSES
}

\author{
Dissertação apresentada à Faculdade de Direito \\ da Universidade de São Paulo para obtenção do \\ título de Mestre em Direito Internacional e \\ Comparado, sob a orientação do Professor \\ Doutor Masato Ninomiya.
}

Candidata: Melissa Chyun Yea Tseng

Faculdade de Direito da Universidade de São Paulo

São Paulo

2014 
BANCA EXAMINADORA 
Aos meus pais. 


\section{AGRADECIMENTOS}

Gostaria de expressar aqui minha gratidão ao Prof. Masato Ninomiya, pela oportunidade de ter recebido sua orientação. Muito admiro a sua longa dedicação aos temas envolvendo as relações entre o Brasil e o Japão, com destaque aos trabalhadores migrantes, objeto da atuação exaustiva do CIATE.

Agradeço à Profa. Akiyo Shimamura, por permitir meu acesso aos seus estudos sobre tema correlato na Faculdade de Direito da Universidade de Tóquio.

Finalmente, gostaria de registrar também meu agradecimento a Belara Giraldelo, uma profissional visivelmente dedicada e apaixonada pelo tema, pelo precioso tempo disponibilizado. 


\section{RESUMO}

O presente trabalho tem por intuito analisar o contexto de proteção social em que estão inseridos os trabalhadores brasileiros que emigraram ao Japão no passado e ainda permanecem naquele país ou que tenham retornado ao Brasil, comparando-se os sistemas de seguridade social japonês e brasileiro.

A comparação em questão visa expor as medidas colocadas em prática não apenas para eliminar a dupla tributação, mas também para garantir os direitos sociais desses trabalhadores migrantes por meio da aplicação do Acordo Previdenciário Brasil-Japão.

O resultado desta pesquisa pretende, por fim, contribuir para o conhecimento dos pesquisadores brasileiros de Direito sobre o tema e, oportunamente, proporcionar reflexões sobre as questões eventualmente suscitadas.

PALAVRAS-CHAVE: SEGURIDADE SOCIAL, PROTEÇÃO SOCIAL, TRABALHADORES MIGRANTES, JAPÃO, DECASSÉGUIS, APOSENTADORIA, SAÚDE, ASSISTÊNCIA SOCIAL, ACORDO PREVIDENCIÁRIO. 


\begin{abstract}
This study aims at analyzing the social protection context in which participate the Brazilian migrant workers who migrated to Japan and there are settled down or are back to Brazil, by comparing the Japanese and the Brazilian social security systems.

This comparison is driven to introduce the measures which have been taken, not only for the purposes of avoiding double taxation, but also to ensure the social rights of these migrant workers, by means of applying the Brazil-Japan Social Security Agreement.

Finally, the results of this research intend to contribute to the knowledge of the Brazilian legal researchers on this subject and, timely, to yield considerations on the possibly arisen issues.
\end{abstract}

KEYWORDS: SOCIAL SECURITY, SOCIAL PROTECTION, MIGRANT WORKERS, JAPAN, DEKASEGIS, RETIREMENT, HEALTHCARE, SOCIAL ASSISTANCE, SOCIAL SECURITY AGREEMENT. 


\section{LISTA DE SIGLAS E ABREVIAÇÕES}

APSAI/SP - Agência da Previdência Social de Atendimento de Acordos Internacionais de São Paulo

BPC-LOAS - Benefício de Prestação Continuada da Assistência Social

CF/88 - Constituição Federal Brasileira de 1988

CIATE - Centro de Informação e Apoio ao Trabalhador no Exterior

CLT - Consolidação das Leis do Trabalho

CNIS - Cadastro Nacional de Informações Sociais

FMI - Fundo Monetário Internacional

IBGE - Instituto Brasileiro de Geografia e Estatística

INSS - Instituto Nacional do Seguro Social

IPSS - Instituto Nacional de Pesquisas sobre a População e Seguridade Social do Japão JPS - Serviço Japonês de Aposentadoria

MHLW - Ministério da Saúde, do Trabalho e do Bem-Estar Social do Japão

MRE - Ministério das Relações Exteriores do Brasil

OCDE - Organização para a Cooperação e Desenvolvimento Econômico

OIT - Organização Internacional do Trabalho

ONU - Organização das Nações Unidas

PIB - Produto Interno Bruto

RGPS - Regime Geral da Previdência Social 


\section{SUMÁRIO}

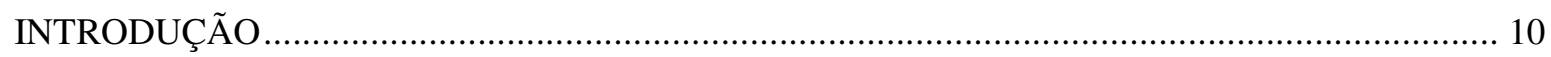

CAPÍTULO I - ORIGEM E CONCEITO DE SEGURIDADE SOCIAL E SUA EVOLUÇÃO NO

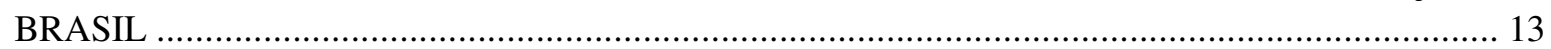

1. Origem e evolução histórica da seguridade social no mundo .................................................... 13

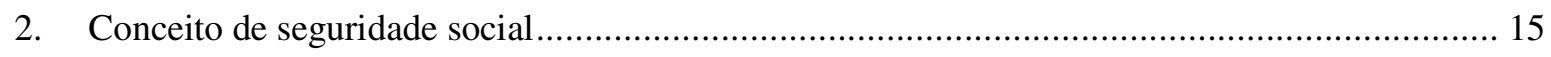

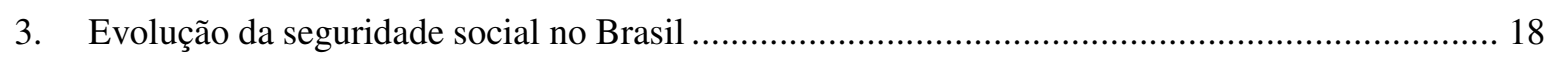

CAPÍTULO II - DA SEGURIDADE SOCIAL NO BRASIL ........................................................ 22

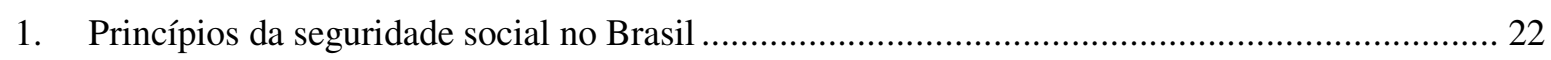

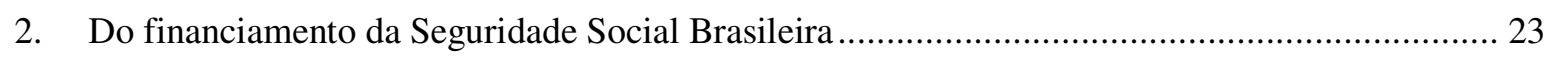

3. Os direitos protegidos pela Seguridade Social nos termos da Constituição Federal Brasileira .... 25

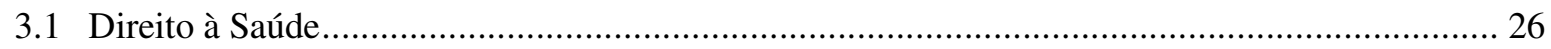

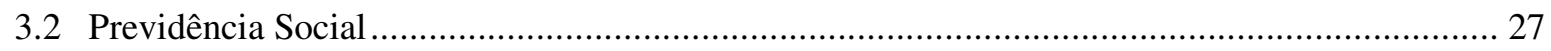

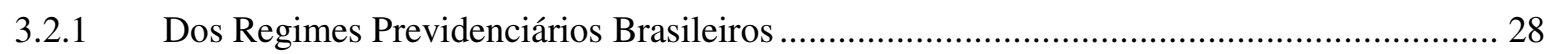

3.2.2 Dos beneficiários do Regime Geral da Previdência Social ............................................... 30

3.2.3 Das prestações previdenciárias...................................................................................... 32

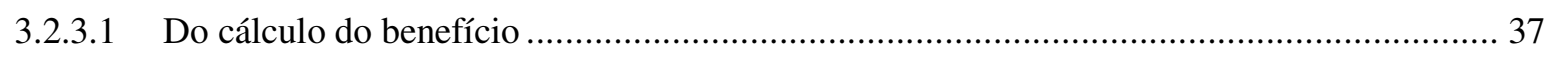

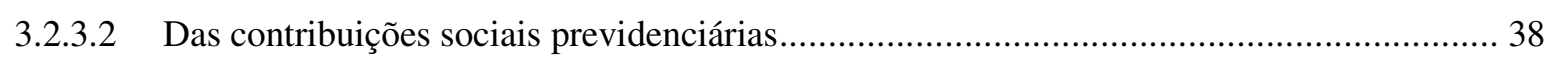

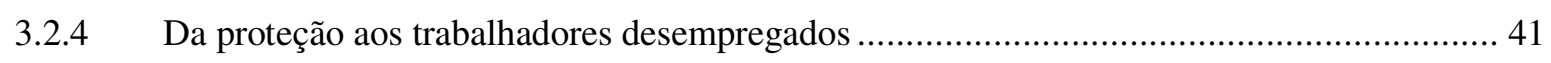

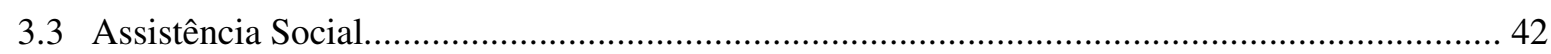

CAPÍTULO III - CONTEXTO HISTÓRICO, ECONÔMICO E SOCIAL DA EVOLUÇÃO DA

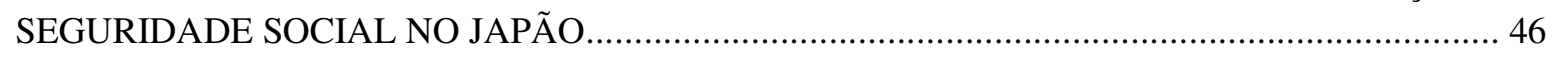

1. O cenário econômico do Japão e suas influências sobre o mercado de trabalho ............................ 46

2. Aspectos jurídicos trabalhistas no Japão: a posição das cortes com relação à demissão de

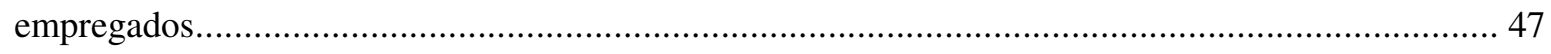

3. A migração dos trabalhadores estrangeiros para o Japão, com destaque para os brasileiros........ 49

4. A seguridade social no Japão nesse contexto de mudanças.......................................................... 51

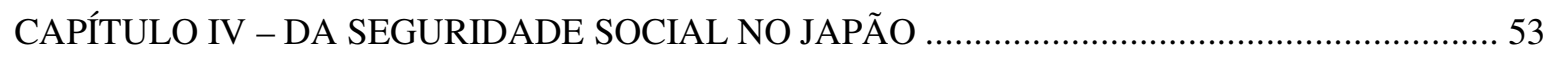

1. Da terminologia utilizada na literatura estrangeira quanto à seguridade social do Japão.............. 53

2. A evolução do sistema de seguridade social do Japão ............................................................. 56

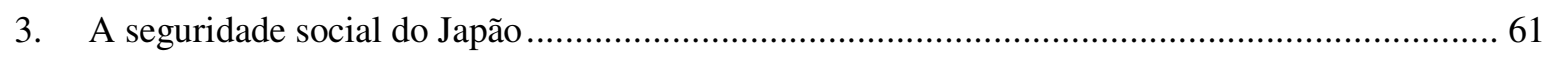

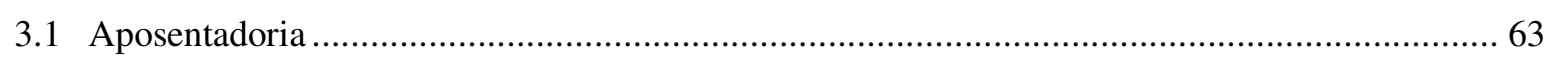

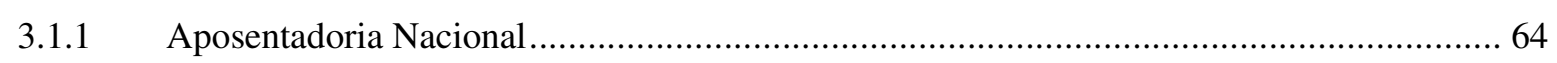




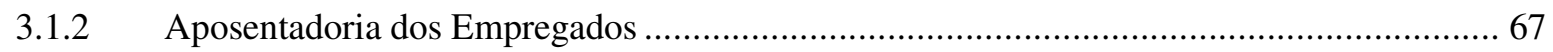

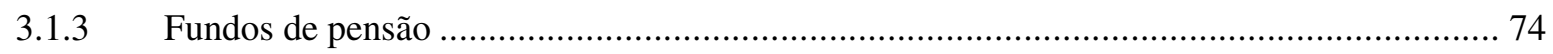

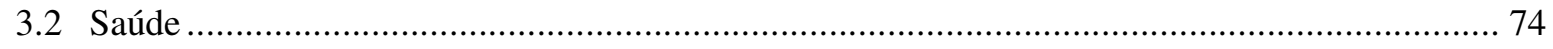

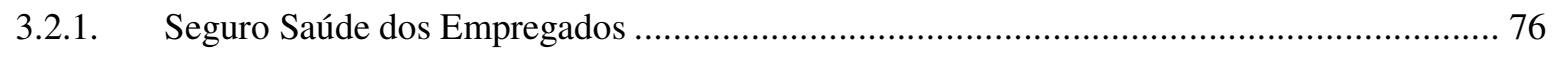

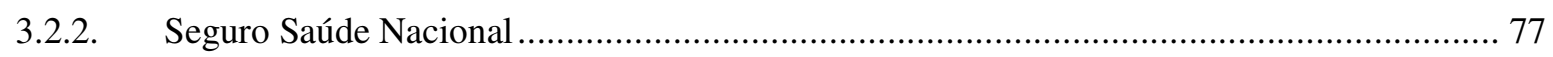

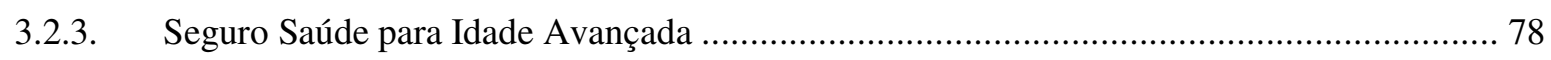

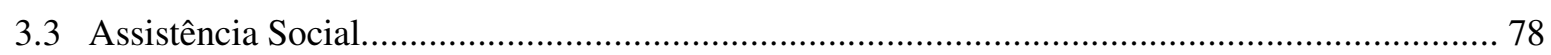

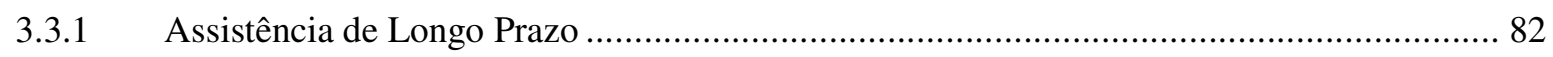

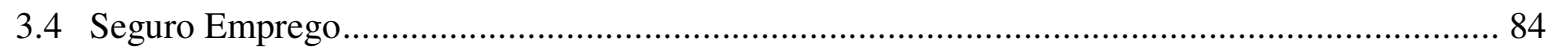

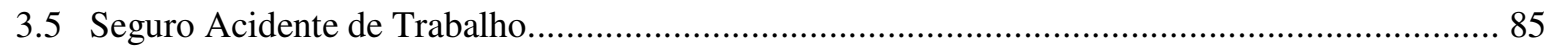

CAPÍTULO V - DA RELAÇÃO ENTRE OS SISTEMAS DE SEGURIDADE SOCIAL DO BRASIL

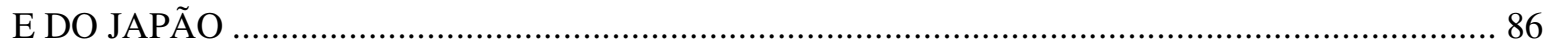

1. Do tratamento em matéria de seguridade social conferido aos brasileiros residentes no Japão e aos

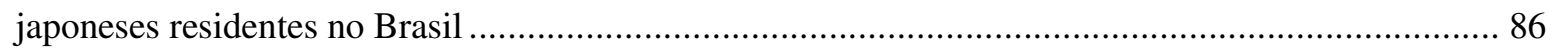

2. Da igualdade de tratamento em matéria de previdência conferida aos brasileiros residentes no

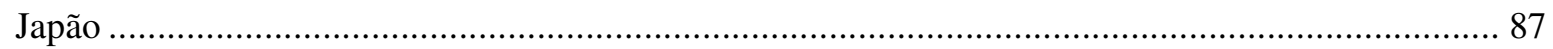

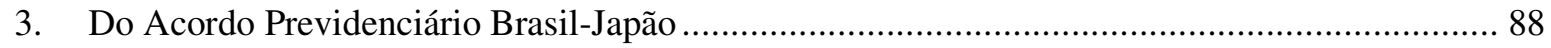

3.1 Da aplicação do Acordo Previdenciário aos brasileiros residentes no Japão................................ 89

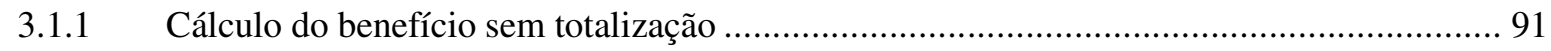

3.1.2 Cálculo do benefício com totalização (quando são considerados os tempos de contribuição

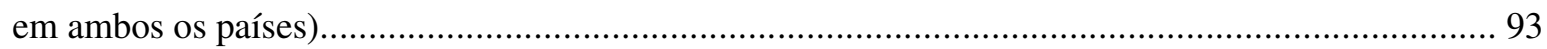

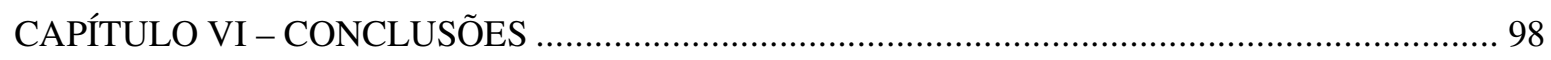

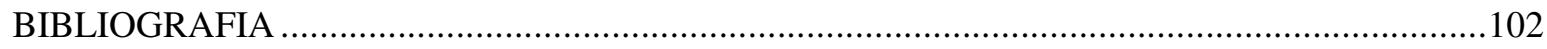

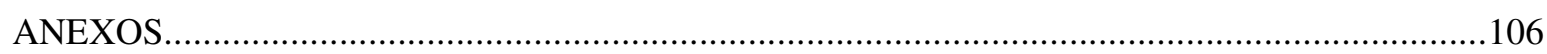

I) Constituição do Japão de 1947 (em inglês) ..............................................................................106

II) Lei de Assistência Pública do Japão (em inglês)...................................................................121

III) Lei de Assistência de Longo Prazo do Japão, artigos 1-13(em inglês)........................................167

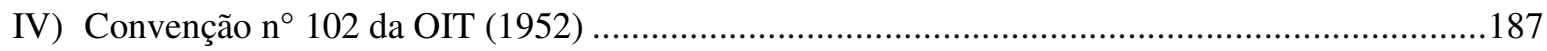

V) Acordo de Previdência Social entre o Brasil e o Japão ............................................................215 


\section{INTRODUÇÃO}

A relação diplomática entre o Brasil e o Japão é de longa data, tendo sido celebrado o Tratado de Amizade, Comércio e Navegação em 1895. A imigração japonesa foi logo iniciada em 1908, com a chegada do navio Kasato Maru. Exceto por um período em que as relações diplomáticas foram interrompidas, após a Segunda Guerra Mundial (entre 1942 e 1952), os laços entre os dois países têm se estreitado cada vez mais. Somente em 1993 foi extinta a emigração oficial, estimulada pelo governo japonês através da Agência Internacional de Cooperação do Japão (JICA). Em 2008 foi celebrado o Centenário da Imigração Japonesa no Brasil.

Após o término da ocupação militar norte-americana e a estabilização das bases institucionais japonesas, principalmente com a promulgação da nova Constituição democrática em 1946, o Japão passou por um período de grande crescimento industrial e recuperação econômica (1960-1980). Nessa época, o Brasil começou a receber investimentos de grandes empresas japonesas que vieram se estabelecer, desde as trading companies (Marubeni, Mitsubishi, Itochu, Sojitz e Mitsui) até as indústrias (Ajinomoto, Panasonic, Toshiba, NEC, Honda, Yamaha, Sony, Sharp, Toyota, entre outros $\left.{ }^{1}\right)$.

Tradicional exportador de produtos primários, o Brasil até então não havia experimentado igual crescimento econômico e industrial, tendo inclusive sido exposto a uma crise econômica na década de 80 . Se no começo do século XX os imigrantes japoneses vinham trabalhar nas fazendas de café e outras lavouras, seus descendentes brasileiros decidiram, nos anos 80, inverter esse fluxo migratório e se dirigir em grande número ao país de seus ancestrais, dando início ao fenômeno migratório denominado "decasségui”.

Em japonês, decasségui significa "o ato de trabalhar longe de casa", originalmente se referindo aos trabalhadores rurais que se dirigiam às cidades no inverno para trabalhar e poupar o que conseguissem. Com o tempo, entre os nipodescendentes brasileiros o termo passou a designar os trabalhadores que iam trabalhar no Japão.

\footnotetext{
${ }^{1}$ Fonte: http://www.itamaraty.gov.br/temas/temas-politicos-e-relacoes-bilaterais/asia-e-oceania/japao/pdf (acesso em 24/06/2012)
} 
Em 1990, com o intuito de suprir a demanda por mão-de-obra em suas indústrias, o Japão começou a emitir vistos de trabalho especiais para os descendentes de japoneses. Porém, importante observar que essa demanda era principalmente por mão-de-obra não qualificada, dirigida aos empregos denominados " $3 \mathrm{~K}$ " que os próprios japoneses, sem rodeios, desprezavam por considerá-los kitsui, kitanai e kiken, significando respectivamente árduo, sujo e perigoso.

Diante da crise econômica mundial que atingiu seu pico em 2008, com a queda da procura por bens de consumo japoneses, o setor industrial do país perdeu mercado e se viu obrigado a demitir seus empregados, aumentando o nível de desemprego no país ${ }^{2}$.

Nesse contexto, uma parte dos primeiros decasséguis (que foram para o Japão entre os anos 80 e 90) já havia poupado recursos o bastante para retornar ao Brasil ou se estabelecer definitivamente no Japão.

Por outro lado, muitos outros trabalhadores brasileiros emigrantes haviam planejado ficar por pouco tempo no Japão e, embora a maioria conhecesse o sistema de seguridade social japonês, preferiram não contribuir para tentar economizar seus proventos ao máximo. Na prática, ao deparar com uma abrupta ruptura de seus contratos de trabalho em razão dessas crises econômicas, muitos indivíduos não haviam atingido o tempo necessário de contribuição e/ou a idade mínima e, por isso, não puderam planejar adequadamente sua aposentadoria.

Desse modo, ignorando a importância de contribuir para o sistema japonês (shakai hoken) e, tendo igualmente deixado de contribuir ao sistema brasileiro, muitos trabalhadores brasileiros tornaram-se, grosso modo, socialmente desprotegidos nas duas jurisdições.

Mesmo aqueles que contribuíram no Japão, quando retornaram ao Brasil, perceberam que não poderiam usufruir de vários benefícios porque as contribuições sociais lá recolhidas não poderiam ser reconhecidas aqui. Felizmente adveio a assinatura do Acordo Previdenciário

2 Fonte: http://www.nytimes.com/2009/04/23/business/global/23immigrant.html?pagewanted=1 (acesso em 23/06/2012) 
entre o Japão e o Brasil, que entrou em vigor em $1^{\circ}$ de março de 2012 , tornando possível dirimir algumas dessas questões.

Em 2006, antes da crise de 2008, havia uma estimativa de mais de 310 mil brasileiros residindo no Japão. Hoje, calcula-se que há cerca de 210 mil brasileiros ${ }^{3}$ vivendo no Japão. Logo, embora em escala inferior, o movimento migratório brasileiro no Japão ainda é presente e relevante ${ }^{4}$.

A presença desses trabalhadores brasileiros no território japonês, bem como o retorno dos decasséguis ao Brasil, torna necessário apreender as circunstâncias em que esses trabalhadores não estão socialmente protegidos ou correm riscos nesse sentido, sob o ponto de vista da análise das medidas de proteção social já previstas no sistema de seguridade social japonês, além do próprio sistema de seguridade social brasileiro.

Portanto, nessa oportunidade, serão trazidos os elementos de conexão entre o sistema de seguridade social japonês e o sistema de seguridade social brasileiro, analisados exclusivamente sob o ponto de vista do Direito Internacional ${ }^{5}$.

\footnotetext{
${ }^{3}$ Como divulgado pelo CIATE em Do Japão ao Brasil: retornando à origem. CIATE - 20 anos de história, São Paulo, 2012, p. 63.

${ }^{4}$ Recentemente o MRE publicou relatório apresentando dados levantados pelo Censo 2010 do IBGE, segundo o qual o Japão ainda é o quarto principal destino dos brasileiros emigrantes, atrás apenas dos Estados Unidos, Portugal e Espanha. Inclusive, o Japão é o segundo país que mais recebe emigrantes brasileiros dos Estados de São Paulo e Paraná, atrás apenas dos Estados Unidos. Fonte: http://www.brasileirosnomundo.itamaraty.gov.br/noticias/censo-ibge-estima-brasileiros-no-exterior-em-cerca-de500-mil/impressao (acesso em 05/05/2013)

${ }^{5}$ As informações apresentadas neste trabalho relativamente aos benefícios brasileiros, bem como sobre as demais características do sistema de seguridade social brasileiro, visam exclusivamente à sua contextualização na comparação com o sistema de seguridade social japonês e, portanto, não pretendem esgotar todas as questões relacionadas ao tema.
} 


\section{CAPÍTULO I - ORIGEM E CONCEITO DE SEGURIDADE SOCIAL E SUA EVOLUÇÃO NO BRASIL}

1. Origem e evolução histórica da seguridade social no mundo

No curso da evolução histórica da humanidade, observou-se que o homem sempre esteve exposto a eventos imprevisíveis que diminuem ou eliminam sua capacidade laboral, ou vêm até mesmo a causar sua morte, deixando social e financeiramente desamparadas sua família e outras pessoas que dependem de seu trabalho para subsistir.

A exposição do homem a acidentes, doenças, desemprego ou outras circunstâncias fortuitas não apenas ameaçam a subsistência humana, mas também geram a insegurança social, pois muitas vezes os indivíduos e a coletividade não dispõem de recursos suficientes guardados para esses momentos de necessidade.

Para fins de prevenção dos possíveis prejuízos relacionados, buscou-se criar uma rede de proteção social, evoluída a partir da beneficência ou filantropia para a seguridade social. Se até a Idade Média era a Igreja que prestava auxílio aos necessitados por motivações puramente morais ou religiosas, a Revolução Industrial criou a figura do trabalhador assalariado, na época carente de proteção contra acidentes de trabalho, doenças, invalidez e morte. E foi a partir desse ponto que tal proteção foi gradativamente estendida aos demais membros da sociedade, não trabalhadores.

Inicialmente, há muito tempo, na época da Roma Antiga, a figura do pater familias era incumbida de prestar assistência aos servos e clientes mediante uma associação.

Em 1601, na Inglaterra, foi editada a Lei de Amparo aos Pobres (Poor Relief Act), que determinou o pagamento obrigatório de uma contribuição social por parte de ocupantes e usuários de terras, além de ter consolidado outras leis de assistência social. As paróquias locais eram encarregadas de desenvolver programas de assistência, a fim de auxiliar não apenas os indigentes, mas também as crianças pobres, os idosos e os inválidos, além de proporcionar trabalho aos desempregados. 
Em 1789, no período da Revolução Francesa, foi votada pela Assembleia Constituinte a Declaração dos Direitos do Homem e do Cidadão, que previa um modelo de proteção social de caráter público e contributivo, integrando uma das bases da gestão pública e repartindo as despesas relacionadas de forma igual entre todos os cidadãos.

Com a finalidade de angariar apoio popular e diminuir a influência das ideias socialistas, fortalecidas após a crise industrial, o sistema de seguro social foi implantado na Prússia, atual Alemanha. As principais leis protetivas editadas foram as seguintes: do seguro-doença, em 1883 (custeado por contribuições de empregados, empregadores e Estado), do acidente de trabalho, em 1884 (custeado pelos empregados) e do seguro invalidez e idade, em 1889 (custeado pelos trabalhadores, empregadores e Estado).

A Igreja se preocupou com a instituição de um sistema que formasse um pecúlio para o trabalhador, publicando em 1891 a Encíclica Rerum Novarum do Papa Leão XIII, que trazia alguns princípios que norteariam as relações entre operários e patrões.

$\mathrm{Na}$ Inglaterra foi introduzida uma série de leis de proteção social, quais foram: Workmen's Compensation Act (1897), que instituiu o seguro obrigatório contra acidentes de trabalho, sendo o empregador responsável objetivo pela reparação dos danos; Old Age Pensions (1908), que instituiu a pensão aos maiores de setenta anos de idade, independentemente de contribuições; e a National Insurance Act (1911), que criou o sistema compulsório de contribuição social a cargo dos empregadores, empregados e do Estado.

A primeira Constituição a incorporar o seguro social foi a do México, promulgada em 1917.

Por sua vez, a Constituição de Weimar de 1919 determinou que coubesse ao Estado prover a subsistência do cidadão, caso não lhe pudesse proporcionar a oportunidade de ganhar a vida com um trabalho produtivo.

Também em 1919 foi criada a Organização Internacional do Trabalho (OIT), que tem por objetivo observar e padronizar as condições de trabalho e emprego no mundo a um nível considerado decente. Suas normas são implementadas através de Convenções, 
Recomendações e Resoluções. Diversas Convenções relacionadas ao tema da seguridade social foram publicadas desde então, destacadamente a de $n^{\circ} 102^{6}$.

Com a finalidade de combater a crise econômica de 1929, o presidente dos Estados Unidos, Franklin Roosevelt, instituiu o New Deal por meio da doutrina Welfare State, que objetivava combater a miséria, estabelecendo um conjunto de medidas para criar empregos, além de uma rede de previdência e saúde públicas. Assim, seu Congresso aprovou em 1935 o Social Security Act.

Pouco depois, foi adotado na Inglaterra em 1941 o Plano Beveridge, que tinha por objetivo conferir proteção ao indivíduo "do berço ao túmulo", principalmente por meio da universalização dos benefícios, estendidos não apenas aos trabalhadores, além do custeio tríplice, com predominância da participação do Estado.

Finalmente, é válido relevar a Declaração Universal dos Direitos Humanos, assinada em 1948, que destacava entre os direitos fundamentais humanos a seguridade social, em seus Artigos XXII, XXV e XXVIII.

\section{Conceito de seguridade social}

Historicamente, o conceito de seguridade social baseou-se em dois modelos: continental ou alemão (de 1883) e o atlântico ou inglês (de 1942). O continental destaca-se pela contributividade. O atlântico, por sua vez, é caracterizado pela universalidade e pelo financiamento indireto (com base no orçamento), tendo evoluído a partir da política norteamericana do New Deal (década de 30) para então ganhar repercussão mundial por meio do programa de proteção social criado por William Beveridge, ex-integrante do Parlamento Inglês.

O conceito atual de seguridade social pode ser extraído da própria Declaração Universal dos Direitos Humanos $(1948)^{7}$, segundo a qual todo ser humano tem o direito à consecução dos

\footnotetext{
${ }^{6}$ Ratificada pelo Brasil em 15/06/2009.

${ }^{7}$ Determinam os artigos XXII e XXV da Declaração Universal dos Direitos Humanos:
} 
direitos econômicos, sociais e culturais indispensáveis à sua dignidade, de modo que sejam assegurados ao indivíduo e sua família a saúde e o bem-estar social, inclusive em caso de desemprego, doença, invalidez, viuvez, velhice ou outras circunstâncias fora de seu controle, que venham a lhe tolher os meios de subsistência.

Nesses termos, trata a seguridade social de assegurar que todos os indivíduos usufruam de condições de vida dignas mesmo sob circunstâncias imprevisíveis que possam lhes trazer alguma insegurança social, sendo o provedor dessas condições o próprio Estado.

Não é por demais lembrar que o Programa de Ottawa de Seguridade Social para as Américas, celebrado em 1966 por membros americanos da OIT, determinou que a seguridade social deve integrar a política econômica de um Estado, com vistas a garantir um equilibrado desenvolvimento socioeconômico, além da distribuição equitativa da renda entre a população.

No ordenamento brasileiro, a seguridade social foi definida pelo art. 194 da Constituição Federal como um conjunto integrado de ações de iniciativa dos Poderes Públicos e da sociedade, destinadas a assegurar os direitos relativos à saúde, à previdência social e à assistência social. Os objetivos dessa iniciativa devem ainda corresponder precipuamente a esses pontos: (i) universalidade da cobertura e do atendimento, (ii) uniformidade e equivalência dos benefícios e serviços às populações urbanas e rurais, (iii) seletividade e distributividade na prestação dos benefícios e serviços, (iv) irredutibilidade do valor dos benefícios, (v) equidade na forma de participação no custeio, (vi) diversidade da base de financiamento e (vii) caráter democrático e descentralizado da administração, mediante gestão com participação dos trabalhadores, dos empregadores, dos aposentados e do Governo nos órgãos colegiados.

\section{"Artigo XXII}

Todo ser humano, como membro da sociedade, tem direito à segurança social, à realização pelo esforço nacional, pela cooperação internacional e de acordo com a organização e recursos de cada Estado, dos direitos econômicos, sociais e culturais indispensáveis à sua dignidade e ao livre desenvolvimento da sua personalidade.

\section{Artigo XXV}

1. Todo ser humano tem direito a um padrão de vida capaz de assegurar-lhe, e a sua família, saúde e bem-estar, inclusive alimentação, vestuário, habitação, cuidados médicos e os serviços sociais indispensáveis, e direito à segurança em caso de desemprego, doença, invalidez, viuvez, velhice ou outros casos de perda dos meios de subsistência em circunstâncias fora de seu controle. (...)" 
Vale mencionar que a universalidade, ao mesmo tempo em que estende a proteção a todos os cidadãos, está vinculada ao princípio da igualdade, ou seja, todos os cidadãos devem receber indiscriminadamente a proteção social. Por outro lado, em sendo a universalidade também vinculada ao fundamento constitucional da dignidade humana, é possível ainda apontar para seu caráter tanto subjetivo, quando a proteção é direcionada a todos os cidadãos de um determinado território (possuindo ou não vínculo empregatício), quanto o caráter objetivo, segundo o qual nenhum cidadão pode ser afastado da cobertura dos riscos sociais predeterminados, cobertura esta a ser aplicada individual e concretamente.

Da mesma maneira, a uniformidade e equivalência dos benefícios às populações urbanas e rurais também decorre do primado da igualdade, que implica na não aplicação de discriminações desarrazoadas aos serviços prestados às populações rural e urbana. Se porventura alguma desigualdade de tratamento existir, deverá ser unicamente para diminuir as diferenças nas condições de trabalhos entre estas populações.

A seletividade e a distributividade devem ser aplicadas em conjunto. Na medida em que a seguridade social deve abarcar o maior número de situações de riscos sociais possíveis, o sistema de proteção social deve selecionar aqueles mais importantes e demandados (como a morte, idade avançada, entre outros), distribuindo os benefícios entre a população mais necessitada e de modo a obter o máximo grau de proteção.

A irredutibilidade do valor dos benefícios (tanto quantitativamente, em valor monetário, quanto qualitativamente, em valor real) é necessária em face da própria garantia do mínimo vital a que se presta a proteção social.

A equidade na forma de participação do custeio é um reflexo particular de um dos princípios do sistema previdenciário, o da capacidade contributiva, segundo o qual devem contribuir mais aqueles que têm maior capacidade de contribuir, contribuindo menos ou mesmo deixando de contribuir aqueles desprovidos de condições de contribuir. Seria uma forma de concretização da própria igualdade material, que busca o tratamento igual aos iguais, e desigual aos desiguais. Na realidade, tratar-se-ia da aplicação do próprio princípio da solidariedade, o cerne da seguridade social. 
A diversidade na base do financiamento da seguridade social orienta que sejam buscadas formas de financiamento alternativas em relação à tradicional (comumente a folha de pagamento).

A última das bases da seguridade social, o caráter democrático e descentralizado da administração da seguridade social, é decorrência da democracia direta ou participativa, o que tende a criar um controle mais efetivo das ações estatais por outros integrantes do sistema.

A seguridade social, em suma, designa uma política voltada à proteção das necessidades sociais, sejam elas individuais ou coletivas, prevenindo os riscos e reparando os danos causados pelos eventos que ameaçam a segurança social de todos os membros da sociedade.

\section{Evolução da seguridade social no Brasil}

Somente após a Proclamação da República, em 1889, atentou-se para a proteção social de várias categorias profissionais, tendo sido criados, por exemplo, o montepio obrigatório para os empregados dos Correios, a Caixa de Pensões para os empregados da Imprensa Nacional e a aposentadoria dos ferroviários. Antes disso, o tratamento do assunto era incipiente, com poucas previsões legais.

Com a promulgação da primeira Constituição Republicana em 1891, a aposentadoria por invalidez de funcionários a serviço da nação se tornou uma garantia constitucional.

Destaque-se em seguida a edição da Lei Eloy Chaves (Decreto Legislativo no 4.682 de 24 de janeiro de 1923), que determinou a criação das Caixas de Aposentadoria e Pensões para empregados ferroviários, que protegiam estes de riscos, doenças, invalidez, velhice e morte. Tal lei autorizou cada uma das empresas ferroviárias do país a criar sua Caixa de Aposentadoria e Pensões, além de ter concedido aos ferroviários o direito à estabilidade. A primeira empresa a se basear nessa lei para criar sua Caixa foi a Great Western do Brasil, seguida de outras. $\mathrm{O}$ grande problema era a falta de regulamentação quanto às garantias mínimas, o que só veio a ser sanado anos depois, com a edição da Lei Orgânica da Previdência Social, em 1960. 
Posteriormente à Lei Eloy Chaves foi editado o Decreto $\mathrm{n}^{\circ} 20.465$, de 1931 , que organizou as caixas de aposentadoria e pensões de acordo com as categorias profissionais.

E esse foi o formato seguido nas décadas seguintes pelos Institutos de Aposentadoria e Pensões, derivados dessas caixas e constituídas sob a forma de autarquias federais (prestadoras de serviços autônomos criados por lei e que dispunham de patrimônio próprio), exercendo controle administrativo, financeiro e diretivo sobre as caixas, organizadas de acordo com as categorias profissionais ${ }^{8}$. Embora os direitos previdenciários tenham sido progressivamente homogeneizados, os Institutos não solucionaram a questão da discriminação entre os trabalhadores, pois, aqueles com maior número de associados tinham mais recursos e poderiam reconhecer mais direitos e benefícios em comparação a outros Institutos considerados menores. Com o tempo, o Estado acabou por se tornar gestor do sistema previdenciário.

Esta tendência foi reforçada com a promulgação da Constituição Federal de 1934, que previu expressamente direitos trabalhistas e previdenciários, incluindo a vinculação obrigatória ao sistema de gestão estatal e custeio tripartite (entre trabalhadores, empregadores e Estado).

Já a Constituição Federal de 1937 não chegou a tratar da participação do Estado no custeio.

Por outro lado, a Constituição Federal de 1946 mencionou pela primeira vez "previdência social" no lugar de "seguro social", além de ter determinado o custeio tripartite e a obrigatoriedade da instituição do seguro pelo empregador contra acidentes de trabalho.

A edição do Decreto n 35.448 em 1954, conhecido como o Regulamento Geral dos Institutos de Aposentadoria e Pensões, que uniformizou os princípios gerais aplicáveis a todos os Institutos, foi considerado o ponto de partida para a unificação das normas aplicáveis ao sistema previdenciário brasileiro.

\footnotetext{
${ }^{8}$ Ao longo dos anos 30 foram criados importantes Institutos de Aposentadoria e Pensões, por exemplo, dos Bancários (IAPB), dos Comerciários (IAPC), dos Industriários (IAPI) e dos Servidores dos Estados (IPASE).
} 
Este processo de unificação foi finalmente consolidado pela Lei $n^{\circ} 3.807$ de 1960, a Lei Orgânica de Previdência Social (LOPS) que, além de ter unificado os benefícios e serviços previdenciários (o que eliminou as diferenças de tratamento entre os trabalhadores), conferiu igualdade no custeio por meio da uniformização de alíquotas de contribuição sobre a remuneração do trabalhador e ampliou os riscos acobertados.

É essencial mencionar também a criação do Instituto Nacional de Previdência Social (INPS) pelo Decreto-Lei $n^{\circ} 72 / 1966$, que unificou os institutos previdenciários sob a gestão estatal, mas não eliminou completamente a existência e atuação paralela de outros institutos ${ }^{9}$.

Com a promulgação da Constituição Federal de 1967, o tempo de serviço da mulher foi limitado a trinta anos, o salário-família passou a ser constitucionalmente protegido, bem como o seguro-desemprego.

Também é de 1967 a Lei no 5.316, que estatizou o Seguro Contra Acidentes de Trabalho (SAT), substituto do modelo tradicional em que o risco era controlado na maioria das vezes por seguradoras privadas ${ }^{10}$. Aqui, o dano sofrido passou a corresponder a uma indenização, pela qual deve o empregador se encarregar e que é transferível à entidade seguradora, com a qual era firmado um contrato de seguro obrigatório.

Finalmente, veio a Constituição Federal de 1988, que previu a seguridade social a ser custeada entre Estado (União, Estados da Federação, Distrito Federal e Municípios), empregador e segurados pessoas físicas (trabalhadores ou não trabalhadores). Sua atuação está dividida entre Previdência Social, Assistência à Saúde e Assistência Social.

Pouco depois foram editadas as Leis $n^{\circ} 8.212$ e 8.213 em 1991 que dispõem, respectivamente, do plano de custeio e do plano de benefícios, entre outras questões. Ambas as leis foram regulamentadas pelo Decreto $n^{\circ} 3.048 / 99$.

\footnotetext{
${ }^{9}$ Como por exemplo, o IPASE.

${ }^{10}$ Com exceção dos Institutos dos Marítimos e dos Empregados dos Transportes de Carga, que funcionavam como seguradoras e administravam diretamente o risco de acidente do trabalho.
} 
Importante mencionar ainda que o Código Penal Brasileiro foi alterado pela Lei ${ }^{\circ}$ 9.983/00, que introduziu os crimes previdenciários em seus artigos 168-A (apropriação indébita previdenciária) e 337-A (sonegação de contribuição previdenciária).

Também em 2000, a Consolidação das Leis de Trabalho (CLT) foi alterada pela Lei $\mathrm{n}^{\circ}$ 10.035, que estabeleceu os procedimentos para a execução das contribuições previdenciárias na Justiça do Trabalho. 


\section{CAPÍTULO II - DA SEGURIDADE SOCIAL NO BRASIL}

1. Princípios da seguridade social no Brasil

A Seguridade Social, conforme já conceituado anteriormente neste trabalho, compreende um conjunto de medidas tomadas pelo Poder Público com a participação da sociedade, visando a proteger os direitos à saúde, à previdência social e à assistência social, observando os princípios e diretrizes constitucionais.

Tais princípios e diretrizes dizem respeito à universalidade da cobertura e do atendimento, à uniformidade e equivalência dos benefícios e serviços às populações urbanas e rurais, à seletividade e distributividade na prestação dos benefícios e serviços, à irredutibilidade do valor dos benefícios, à equidade na forma de participação do custeio, à diversidade da base de financiamento, e ao caráter democrático e descentralizado da gestão administrativa.

A universalidade da cobertura e do atendimento intenta que as prestações previdenciárias previnam o maior número possível de contingências sociais que possam ocorrer. Soma-se a esse fato a possibilidade de todos os integrantes da sociedade brasileira se filiarem ao sistema previdenciário, quando atendidos todos os requisitos legais, o que garante a abrangência da cobertura.

A uniformidade e equivalência dos benefícios e serviços às populações urbanas e rurais foram observadas pela previsão de um único sistema previdenciário para ambas as populações, urbana e rural, pela Constituição Federal, que teve por intuito eliminar toda e qualquer forma de discriminação entre elas. Isso porque, até meados dos anos 70, não estavam consolidadas as normas relativas à proteção das populações rurais, o que colaborou para o êxodo rural à época.

A seletividade e distributividade na prestação dos benefícios e serviços devem ser baseadas no princípio da universalidade, sempre que possível, sendo os riscos selecionados pelo legislador de acordo com a capacidade econômica do Estado. O Brasil já havia adotado o conceito de norma mínima protetiva trazido pela Convenção $\mathrm{n}^{\mathrm{o}} 102$ da OIT, antes mesmo de tê-la ratificado. 
A irredutibilidade do valor dos benefícios diz respeito não apenas ao valor nominal, mas também ao real. Fala-se em irredutibilidade quando da concessão dos benefícios (que deve refletir os ganhos habituais do empregado incorporados ao salário), e também quando do reajuste dos benefícios previdenciários (que deve preservar seu poder de compra).

A equidade na forma de participação no custeio decorre da própria capacidade contributiva do contribuinte. Assim, o custeio da seguridade social deve ser efetuado com justiça e igualdade, porquanto se adotam as alíquotas progressivas.

A diversidade da base de financiamento é necessária para conferir segurança e estabilidade ao sistema de seguridade social. Na prática, toda a sociedade a financia, com a ajuda da União e demais Poderes Públicos.

Finalmente, o caráter democrático e descentralizado da gestão administrativa implica na participação da comunidade, em especial de trabalhadores, empresários e aposentados. Reflexo do Estado Democrático de Direito, o sistema de seguridade social brasileiro é administrado com efetiva participação dos trabalhadores, empregadores, aposentados, bem como do Governo, a exemplo do Conselho Nacional de Previdência Social (CNPS), órgão deliberativo composto por representantes da sociedade civil e da União Federal. A fim de ganhar mais eficiência, a gestão também é descentralizada, feita por uma autarquia federal, o Instituto Nacional da Seguridade Social (INSS) e não concentrada no próprio Estado.

\section{Do financiamento da Seguridade Social Brasileira}

A seguridade social é financiada por toda a sociedade, de forma direta ou indireta, por meio dos recursos provenientes dos orçamentos da União, dos Estados, do Distrito Federal e dos Municípios (lembrando que as receitas dos Estados, do Distrito Federal e dos Municípios não integram o orçamento da União Federal).

Como determinado pelo art. 195 da Constituição Federal, a seguridade social também é financiada através de diversas contribuições sociais. 
As primeiras delas são aquelas pagas pelo empregador, pela empresa e pela entidade a ela equiparada na forma da lei, incidentes sobre: (i) a folha de salários e demais rendimentos de trabalho pagos ou creditados, a qualquer título, à pessoa física que lhe preste serviço, mesmo sem vínculo empregatício ${ }^{11}$; (ii) a receita ou faturamento, referindo-se às Contribuições ao Programa de Integração Social e Programa de Formação do Patrimônio do Servidor Público (PIS/PASEP) e às Contribuições para o Financiamento da Seguridade Social (COFINS); e também sobre (iii) o lucro, que diz respeito à Contribuição Social sobre o Lucro Líquido (CSLL).

Além das contribuições previdenciárias pagas pelas empresas, existem aquelas contribuições pagas pelo trabalhador e demais segurados da previdência social, não incidentes sobre a aposentadoria e a pensão concedidas pelo regime geral de previdência social.

O importador de bens ou serviços do exterior, ou de quem a lei a ele o equiparar, deve recolher as Contribuições ao PIS/PASEP e as COFINS para Importações.

As associações desportivas que mantêm equipe de futebol profissional pagam, por sua vez, contribuições incidentes sobre a receita bruta decorrente dos espetáculos desportivos de que participem em todo território nacional em qualquer modalidade desportiva, inclusive jogos internacionais, e de qualquer forma de patrocínio, licenciamento de uso de marcas e símbolos, publicidade, propaganda e transmissão de espetáculos desportivos.

Os produtores rurais devem recolher contribuições incidentes sobre a receita bruta proveniente da comercialização da produção rural.

Por fim, as contribuições são incidentes sobre as receitas de concursos de prognósticos também.

Note-se também que a proposta de orçamento será elaborada de forma integrada pelos órgãos responsáveis pela saúde, previdência social e assistência social, observadas as metas e

\footnotetext{
${ }^{11}$ São as contribuições das empresas, devidas pelos empregadores sobre rendimentos de trabalhador empregado ou de prestador de serviço.
} 
prioridades estabelecidas na lei de diretrizes orçamentárias, assegurada a cada área a gestão de seus recursos.

Interessante registrar ainda que a lei definirá os critérios de transferência de recursos para o Sistema Único de Saúde (SUS) e ações de assistência social da União para os Estados, o Distrito Federal e Municípios, bem como dos Estados para os Municípios, observada a contrapartida de recursos.

Finalmente, dado o objetivo avançado das contribuições, nenhum benefício ou serviço de seguridade social poderá ser criado, majorado ou estendido sem a correspondente fonte de custeio total.

Em seguida, são efetivamente tratados os direitos protegidos em decorrência da garantia constitucional da segurança social.

3. Os direitos protegidos pela Seguridade Social nos termos da Constituição Federal Brasileira

Primeiramente, faz-se necessário mencionar como a Constituição Federal elencou os direitos sociais, destacados como direitos fundamentais:

"Art. $6^{\circ}$ São direitos sociais a educação, a saúde, a alimentação, o trabalho, a moradia, o lazer, a segurança, a previdência social, a proteção à maternidade e à infância, a assistência aos desamparados, na forma desta Constituição."

Conforme dito anteriormente, o art. 194 da Constituição determinou a execução de uma política social por parte dos Poderes Públicos e da sociedade, voltada à proteção dos direitos relativos à saúde, à previdência social e à assistência social, os três pilares da seguridade social. 


\subsection{Direito à Saúde}

A Organização Mundial de Saúde (OMC) conceitua saúde como o estado de completo bemestar físico, mental e social, e não apenas a ausência de doença ou enfermidade ${ }^{12}$.

Este direito fundamental está previsto nos artigos 196 a 200 da Constituição Brasileira, tendo sido definido como um direito de todos e um dever do Estado, garantido por meio de políticas sociais e econômicas que promovem o acesso universal e igualitário a serviços voltados à prevenção e recuperação de doenças.

Segundo a Constituição, o Poder Público deve regulamentar, fiscalizar e exercer o controle sobre os serviços de saúde executados por terceiros, inclusive por pessoas físicas ou jurídicas de direito privado. Já os denominados serviços públicos de saúde compõem uma rede hierarquizada e regionalizada em formato de sistema único, financiado por recursos do orçamento da seguridade social, da União, dos Estados, Municípios e Distrito Federal.

Interessante apontar que o direito à saúde tem uma abordagem coletiva, além da individual. Coletiva porque atenta para os pormenores da fiscalização da saúde pública (desde o controle sanitário de produtos alimentícios até a produção de medicamentos). Individual porque possui um objetivo preventivo e reparador quanto ao estado de bem-estar de um indivíduo, fornecendo-lhe um tratamento de saúde quando necessário.

Mesmo que a Constituição tenha garantido expressamente o acesso universal e igualitário ao sistema de saúde, é preciso se considerar também o princípio da equidade, o que implica na ponderação das necessidades individuais, permitindo-se que aqueles mais carentes de cuidados tenham maior acesso às prestações em relação àqueles com menos necessidades.

\footnotetext{
${ }^{12}$ Definição trazida pelo Preâmbulo da Constituição da OMS conforme adotado na Conferência Internacional da Saúde, realizada em Nova Iorque (19 de junho a 22 de julho de 1946), em vigor desde 07 de abril de 1948. Fonte: http://www.who.int/suggestions/faq/en/index.html
} 
Além disso, aplica-se também o princípio da subsidiariedade, o que significa que o dever do Estado não exclui a responsabilidade das famílias, empresas e sociedade em geral para assegurar o exercício desse direito.

Assim, a fim de prover os serviços de saúde, em observância ao determinado pela Constituição, foi institucionalizado o Sistema Único de Saúde (SUS) pela Lei no 8.080/90.

O SUS é constituído pelo conjunto de ações e serviços de saúde, prestados por órgãos e instituições públicas federais, estaduais e municipais, da administração direta e indireta, além das fundações mantidas pelo Poder Público. Além de formular a política de saúde destinada à sua proteção, nos campos econômico e social, é sua incumbência realizar de forma integrada as ações assistenciais e preventivas, desde a vigilância sanitária e a proteção da saúde do trabalhador até a execução das medidas de saneamento básico.

O financiamento se dá através do orçamento da seguridade social, sendo alocados os recursos necessários à realização de suas finalidades, com base nas propostas elaboradas pela direção nacional do SUS, com a participação dos órgãos de previdência social e da assistência social, tendo em vista as metas e prioridades estabelecidas na Lei de Diretrizes Orçamentárias (conforme disposto pelo art. 31 da Lei $\mathrm{n}^{\circ}$ 8.080/90).

\subsection{Previdência Social}

A previdência social brasileira está disciplinada pelos artigos 201 e 202 da Constituição Federal, que previu sua organização sob a forma de regime geral (regra geral), de caráter contributivo e filiação obrigatória, com vistas a preservar o equilíbrio financeiro e atuarial.

As finalidades da previdência social são: acobertar os eventos de doença, invalidez, morte e idade avançada, além de proteger a maternidade e o trabalhador em situação de desemprego involuntário. Além do mais, deve oferecer o salário-família e auxílio-reclusão aos dependentes dos segurados de baixa renda, bem como a pensão por morte do segurado, esta a ser recebida pelo seu cônjuge ou companheiro (ou companheira) e dependentes. 
Destaque-se que a Carta Magna ainda determinou que nenhum benefício que substitua o salário de contribuição ou o rendimento do trabalho do segurado tenha valor mensal inferior a um salário mínimo.

Em seguida, serão abordados especificamente os regimes previdenciários.

\subsubsection{Dos Regimes Previdenciários Brasileiros}

Os segurados e dependentes são submetidos a diversos tipos de regimes previdenciários (geral ou especial, além do complementar), sendo que, na prática, os benefícios a serem recebidos dependem não apenas da categoria profissional do segurado, como também da data da filiação ao regime, como será visto mais adiante, em virtude da legislação em vigor à época.

Como regra geral, aplica-se aos segurados e dependentes a aposentadoria pelo Regime Geral de Previdência Social (RGPS), condicionada à contribuição por trinta e cinco anos (homem) ou por trinta anos (mulher), além de ter sido atingida a idade de sessenta e cinco anos (homem) ou sessenta anos (mulher).

O Regime Geral é regido pela Lei n ${ }^{\circ}$ 8.212/91 (Lei de Custeio) e pela Lei no 8.213/91 (Lei de Benefícios), sendo regulamentado pelo Decreto $n^{\circ}$ 3.048/99 (Regulamento da Previdência Social) e gerenciado pelo INSS, uma autarquia federal.

Por sua vez, são considerados Regimes Especiais ou Próprios de Previdência Social aqueles regidos por normas editadas pela própria pessoa jurídica de direito público interno que o instituiu, normas estas que devem prever ao menos os benefícios da aposentadoria e da pensão por morte. São aqueles regimes aplicáveis aos servidores públicos civis, aos servidores públicos militares e aos servidores de autarquias (tanto da União quanto dos Estados, Distrito Federal e Municípios).

Em caráter complementar, aplica-se o Regime de Previdência Complementar Privada, de adesão facultativa e organizado de forma autônoma em relação ao RGPS, sendo regulado pela Lei Complementar no 109/2001. 
A relação entre a União, Estados, Distrito Federal ou Municípios (inclusive suas autarquias, fundações, sociedades de economia mista e empresas controladas direta ou indiretamente), enquanto patrocinadoras de entidades fechadas de previdência privada, e suas respectivas entidades fechadas de previdência privada também depende de regulação por lei complementar.

Com relação à sua acessibilidade, as entidades de previdência complementar privada podem ser abertas ou fechadas.

As entidades abertas podem oferecer planos de benefícios (i) individuais, acessíveis por quaisquer pessoas físicas, ou (ii) coletivas, acessíveis apenas por pessoas físicas vinculadas, direta ou indiretamente, à pessoa jurídica contratante. Essas entidades abertas são operadas por instituições financeiras através de títulos de capitalização e fiscalizadas pela Superintendência de Seguros Privados (SUSEP), autarquia vinculada ao Ministério da Fazenda. Devem ser constituídas sob a forma de sociedades anônimas e ter por objetivo instituir e operar planos de benefícios previdenciários no formato de renda continuada ou pagamento único.

Diversamente, as entidades fechadas somente podem ser acessíveis por empregados de uma empresa ou grupo de empresas. Devem ser organizadas sob a forma de fundação ou sociedade civil sem fins lucrativos.

Interessante observar o elemento contratual presente na relação entre os participantes e a entidade de previdência, pois, para ambas as partes, são atribuídas responsabilidades e obrigações a serem cumpridas mediante a observância da boa-fé e sob condições que não podem ser discutidas ou modificadas pelo participante, ou seja, tratar-se-ia essencialmente de um contrato de adesão.

Também merecem atenção alguns elementos peculiares presentes nos planos de previdência privada, como a possibilidade de exercício da portabilidade, correspondente à faculdade do participante transferir os recursos financeiros correspondentes ao seu direito acumulado para outro plano de benefício operado por entidade de previdência complementar. Igualmente, 
existe o vesting ou benefício proporcional diferido, que diz respeito à faculdade do participante, cujo vínculo empregatício com o patrocinador ${ }^{13}$ termina antes da aquisição do direito ao benefício pleno programado, poder optar pelo recebimento futuro dos benefícios sob a forma de renda programada, calculado segundo as regras do plano.

Ademais, é válido ainda abordar os três tipos de planos de previdência privada existentes: de benefício definido (BD), de contribuição definida (CD), além do misto. No plano de BD as contribuições mensais são variáveis, de forma a permitir que o benefício a ser recebido seja preestabelecido. No plano de CD a situação é inversa, pois os valores das contribuições mensais são escolhidas previamente pelo participante e o saldo acumulado até a data do benefício será convertido em renda mensal vitalícia ou em renda por período previamente escolhido pelo contribuinte. Por fim, o plano misto combina elementos dos dois anteriores, com a contribuição definida na fase de acumulação, sendo que na percepção da aposentadoria outros benefícios são integrados, a exemplo do pecúlio, conforme os termos assinados à época da adesão.

\subsubsection{Dos beneficiários do Regime Geral da Previdência Social}

Para fins de referência, antes de adentrar efetivamente nas questões atinentes às prestações previdenciárias, é preciso esclarecer quanto aos beneficiários da Previdência Social nos conformes da legislação brasileira, que enumera basicamente os segurados e seus dependentes.

Os segurados são classificados como obrigatórios ou facultativos. Os segurados obrigatórios compreendem empregados em geral, empregados domésticos, contribuintes individuais, trabalhadores avulsos e segurados especiais. Os segurados facultativos dizem respeito aos indivíduos maiores de 14 (quatorze) anos que se filiarem ao RGPS, mediante contribuição, desde que não incluídos nas demais categorias de segurados, descritos abaixo.

Para fins da legislação previdenciária, são considerados empregados: (i) os prestadores de serviço de natureza urbana ou rural para empresa, em caráter não eventual, sob sua

\footnotetext{
${ }^{13} \mathrm{Ou}$ o vínculo associativo com o instituidor, dependendo do regime de trabalho do participante.
} 
subordinação e mediante remuneração, inclusive como diretor empregado; (ii) os trabalhadores temporários $^{14}$; (iii) o brasileiro/estrangeiro domiciliado e contratado no Brasil para trabalhar em agência ou sucursal de empresa brasileira no exterior; (iv) o prestador de serviços no Brasil para missão diplomática ou repartição consular estrangeira, ou para membros dessas missões e repartições ${ }^{15}$; (v) o brasileiro civil que trabalha para a União, no exterior, em organismos oficiais brasileiros ou internacionais de que o Brasil seja membro; (vi) o brasileiro/estrangeiro domiciliado e contratado no Brasil para trabalhar como empregado em empresa domiciliada no exterior, cuja maioria do capital votante pertença a empresa brasileira de capital nacional; (vii) o servidor público ocupante de cargo em comissão, sem vínculo efetivo com a União, Autarquias, inclusive em regime especial, e Fundações Públicas Federais; (viii) o exercente de mandato eletivo federal, estadual ou municipal, desde que não vinculado a regime próprio de previdência social; e (ix) o empregado de organismo oficial internacional ou estrangeiro em funcionamento no Brasil, salvo quando coberto por regime próprio de previdência social.

É considerado empregado doméstico aquele que presta serviço de natureza contínua a pessoa ou família, no âmbito residencial desta, em atividades sem fins lucrativos.

Por contribuinte individual se entende o titular de firma individual urbana ou rural, o diretor não empregado e o membro de conselho de administração de sociedade anônima, o sócio solidário, o sócio de indústria, o sócio gerente e o sócio cotista que recebam remuneração decorrente de seu trabalho em empresa urbana ou rural, e o associado eleito para cargo de direção em cooperativa, associação ou entidade de qualquer natureza ou finalidade, bem como o síndico ou administrador eleito para exercer atividade de direção condominial, desde que recebam remuneração.

Também são contribuintes individuais quem presta serviço de natureza urbana ou rural, em caráter eventual, a uma ou mais empresas, sem relação de emprego; a pessoa física que exerce, por conta própria, atividade econômica de natureza urbana, com fins lucrativos ou não; as

\footnotetext{
${ }^{14}$ Definidos em lei específica.

${ }^{15}$ Excluídos o não brasileiro sem residência permanente no Brasil e o brasileiro amparado pela legislação previdenciária do país da respectiva missão diplomática ou repartição consular.
} 
pessoas físicas que exploram a agropecuária, a pesca ou a extração mineral, como definido em lei; os ministros de confissão religiosa e membro de instituto de vida consagrada, de congregação ou de ordem religiosa; e o brasileiro civil que trabalha no exterior para organismo oficial internacional do qual o Brasil é membro efetivo, ainda que lá domiciliado e contratado, salvo quando coberto por regime próprio de previdência social.

Ademais, é considerado trabalhador avulso quem presta a diversas empresas, sem vínculo empregatício, serviço de natureza urbana ou rural, como definido em lei.

A última das categorias de segurados obrigatórios, o segurado especial, é referente: (i) a pessoa física residente no imóvel rural ou em aglomerado urbano ou rural próximo a ele que, individualmente ou em regime de economia familiar, ainda que com o auxílio eventual de terceiros, explore a agropecuária, o extrativismo vegetal ou a pesca artesanal, além de (ii) seu cônjuge/companheiro e seu filho maior de 16 (dezesseis) anos de idade que comprovadamente trabalhem com o respectivo grupo familiar, nos termos da lei.

Finalmente, os segurados dependentes dizem respeito a: (i) cônjuge, a companheira, o companheiro e o filho não emancipado, de qualquer condição, menor de 21 (vinte e um) anos ou inválido ou que tenha deficiência intelectual ou mental que o torne absoluta ou relativamente incapaz, assim declarado judicialmente; (ii) os pais; ou, ainda, (iii) o irmão não emancipado, de qualquer condição, menor de 21 (vinte e um) anos ou inválido ou que tenha deficiência intelectual ou mental que o torne absoluta ou relativamente incapaz, assim declarado judicialmente.

\subsubsection{Das prestações previdenciárias}

As prestações previdenciárias para o RGPS são classificadas em benefícios (valores pagos em dinheiro para segurados e dependentes, com o intuito de atenuar ou eliminar o estado de necessidade social) e serviços sociais (prestações assistenciais para os beneficiários em geral). 
Os benefícios previdenciários concedidos a segurados são a Aposentadoria por Idade, Aposentadoria por Invalidez, Aposentadoria por Tempo de Contribuição, Aposentadoria Especial, Auxílio-Doença, Salário-Família, Salário-Maternidade e Auxílio-Acidente.

A Aposentadoria por Idade exige o cumprimento de uma carência ${ }^{16}$ de 180 (cento e oitenta) contribuições mensais (para os inscritos a partir de 25/07/1991 ${ }^{17}$ ). É devida ao segurado que, além de ter cumprido esta carência, completar 65 (sessenta e cinco) anos de idade, se homem, e 60 (sessenta), se mulher, idades reduzidas respectivamente para 60 (sessenta) e 55 (cinquenta e cinco) anos no caso de trabalhadores rurais. Consistirá numa renda mensal ${ }^{18}$ de $70 \%$ (setenta por cento) do salário-de-benefício ${ }^{19}$, mais $1 \%$ (um por cento) deste, por grupo de 12 (doze) contribuições, não podendo ultrapassar $100 \%$ (cem por cento) do salário-de-benefício ${ }^{20}$.

Por sua vez, a Aposentadoria por Invalidez requer o cumprimento da carência de 12 (doze) contribuições mensais. É devida ao segurado que, estando ou não em gozo de auxílio-doença, for considerado incapaz e insuscetível de reabilitação para o exercício de atividade que lhe garanta a subsistência $^{21}$, sendo-lhe paga enquanto permanecer nesta condição ${ }^{22}$. O benefício consiste numa renda mensal correspondente a $100 \%$ (cem por cento) do salário-de-benefício.

\footnotetext{
${ }^{16}$ Período de carência é o número mínimo de contribuições mensais indispensáveis para que o beneficiário faça jus ao benefício, consideradas a partir do transcurso do primeiro dia dos meses de suas competências (art. 24 da Lei $\left.\mathrm{n}^{\circ} 8.213 / 91\right)$.

${ }^{17}$ Trata-se da data da entrada em vigor da Lei n ${ }^{\circ}$ 8.213/91. Os inscritos até 24/07/1991 precisaram observar a tabela progressiva prevista pelo art. 142 da Lei de Benefícios, que levou em consideração o ano em que o segurado completou o requisito etário (idade).

${ }^{18}$ Note-se que, para fins de obtenção dessa renda mensal, o segurado que solicitar a Aposentadoria por Idade poderá ou não multiplicar tal média pelo fator previdenciário, conforme o critério que lhe for mais vantajoso, nos termos do art. 181-A do Decreto ${ }^{\circ} 3.048 / 99$.

${ }^{19}$ Como regra, o salário-de-benefício corresponde à média de $80 \%$ dos maiores salários-de-contribuição até a data do requerimento do benefício. Será melhor explicado no item seguinte deste trabalho.

${ }^{20}$ Não poderá a Aposentadoria por Idade ser acumulada com outras aposentadorias ou outros benefícios em geral, como o auxílio-doença e seguro-desemprego.

${ }^{21}$ Condição atestada por perícia médica, feita com regularidade bienal.

${ }^{22}$ A qualidade de segurado é mantida, independentemente de contribuições, pelo período de até doze meses após a cessação de benefício por incapacidade ou após a cessação das contribuições, no caso de segurado que deixar de exercer atividade remunerada abrangida pela previdência social ou estiver suspenso ou licenciado sem remuneração, conforme dispõe o art. 13, II do Decreto $n^{\circ} 3.048 / 99$.
} 
Diferentemente das categorias de aposentadoria anteriormente mencionadas, a Aposentadoria por Tempo de Contribuição ${ }^{23}$ pode exigir de seu solicitante um "pedágio", além das condições idade e tempo de contribuição.

Assim, o filiado ao RGPS até 16/12/1998 ${ }^{24}$ que houver cumprido a carência exigida poderá solicitar o direito à Aposentadoria por Tempo de Contribuição Proporcional ${ }^{25}$ desde que tenha atingido 53 anos de idade (homem) e 48 anos de idade (mulher), além de ter cumprido o tempo de contribuição de 30 anos (homem) e 25 anos (mulher), mais um período adicional de $40 \%$ do tempo que em 16/12/1998 faltava para completar esse tempo de contribuição (esse período adicional é denominado "pedágio"). Nesse caso, a renda mensal da aposentadoria proporcional corresponderá a $70 \%$ do salário-de-benefício ${ }^{26}$ mais $5 \%$ por ano de contribuição que supere a soma do tempo de contribuição ${ }^{27}$ e do adicional de $40 \%$, limitado a $100 \%$.

Já o filiado ao RGPS a partir de 16/12/1998 poderá solicitar a Aposentadoria por Tempo de Contribuição caso tenha completado 35 anos de contribuição (homem) e 30 anos de contribuição (mulher) ${ }^{28}$. Nesse caso, a renda mensal corresponderá a $100 \%$ do salário-debenefício aos 30 anos de contribuição (mulher) e 35 anos de contribuição (homem) ${ }^{29}$.

A Aposentadoria Especial também exige a observância da carência de 180 (cento e oitenta) contribuições mensais. Será devida ao segurado que houver trabalhado sob condições especiais que tenham prejudicado sua saúde ou integridade física (efetiva exposição aos agentes nocivos químicos, físicos, biológicos ou associação de agentes prejudiciais), durante

\footnotetext{
${ }^{23}$ A Aposentadoria por Tempo de Contribuição, um tema ainda polêmico e recorrente na doutrina e jurisprudência brasileiras, não será analisada em profundidade neste trabalho, desenvolvido exclusivamente sob a ótica do Direito Internacional. As informações apresentadas neste trabalho relativamente aos benefícios brasileiros visam exclusivamente à contextualização do sistema de seguridade social brasileiro em sua comparação com o sistema de seguridade social japonês e, portanto, não pretendem esgotar todas as questões relacionadas ao tema.

${ }^{24}$ Data da entrada em vigor da Emenda Constitucional n ${ }^{\circ}$ 20/98, que incorporou essas condições à Aposentadoria por Tempo de Contribuição.

${ }^{25}$ Nos termos do art. 188 do Decreto ${ }^{\circ}$ 3.048/99.

${ }^{26}$ Aos 35 anos de contribuição, para o homem, ou 30 anos de contribuição, para a mulher.

${ }^{27}$ De 30 anos para o homem e 25 anos para a mulher.

${ }^{28}$ Nos termos do art. 56 do Decreto ${ }^{\circ} 3.048 / 99$.

${ }^{29}$ Nos termos do art. 39, IV c/c art. 57 do Decreto ${ }^{\circ}$ 3.048/99.
} 
15 (quinze), 20 (vinte) ou 25 (vinte e cinco) anos, conforme o agente nocivo ${ }^{30}$. Consistirá numa renda mensal de $100 \%$ (cem por cento) do salário-de-benefício.

O Auxílio-Doença requer o cumprimento da carência de 12 (doze) contribuições mensais. É devido ao segurado que ficar incapacitado para o seu trabalho ou para a sua atividade habitual por mais de 15 (quinze) dias consecutivos. Consistirá numa renda mensal correspondente a 91\% (noventa e um por cento) do salário-de-benefício.

O Salário-Família, por sua vez, independe de carência. Será devido, mensalmente, ao segurado empregado de baixa renda (excetuados os domésticos), e ao segurado trabalhador avulso de baixa renda, na proporção do respectivo número de filhos ou equiparados.

Voltada à mulher segurada da Previdência Social, o Salário-Maternidade exige a carência de 10 (dez) contribuições mensais para as seguradas individuais, especiais e facultativas (seguradas empregadas e trabalhadoras avulsas estão dispensadas de carência). É devido durante 120 (cento e vinte) dias, com início no período entre 28 (vinte e oito) dias antes do parto e a data de ocorrência deste, observadas as situações e condições previstas na legislação no que concerne à proteção à maternidade. Para a segurada empregada, consistirá numa renda mensal igual à sua remuneração integral.

Outro benefício para segurados, o Auxílio-Acidente independe de carência. Será concedido como indenização ao segurado quando, após consolidação das lesões decorrentes de acidente de qualquer natureza, resultarem sequelas que impliquem redução da capacidade para o trabalho que habitualmente exercia. $O$ auxílio-acidente mensal corresponderá a 50\% (cinquenta por cento) do salário-de-benefício e será devido até a véspera do início de qualquer aposentadoria ou até a data do óbito do segurado. Pode ter valor inferior ao salário-mínimo devido à sua natureza indenizatória, não remuneratória.

Há também os benefícios previdenciários concedidos a dependentes, quais sejam, a Pensão por Morte e o Auxílio-Reclusão.

\footnotetext{
${ }^{30}$ Conforme a tabela de tempo de exposição a agente nocivo, prevista pelo Anexo IV do Decreto n ${ }^{\circ}$ 3.048/99.
} 
A Pensão por Morte independe de carência. Será devida ao conjunto dos dependentes do segurado que falecer, aposentado ou não, a contar da data (i) do óbito, quando requerida até trinta dias depois deste; (ii) do requerimento, quando requerida após o prazo anteriormente referido de trinta dias; ou (iii) da decisão judicial, no caso de morte presumida. $\mathrm{O}$ valor mensal da pensão por morte será de $100 \%$ (cem por cento) do valor da aposentadoria que o segurado recebia ou daquela a que teria direito se estivesse aposentado por invalidez na data de seu falecimento.

O Auxílio-Reclusão também independe de carência. Será devido aos dependentes do segurado de baixa renda recolhido à prisão, que não receber remuneração da empresa (nem estiver em gozo de auxílio-doença, de aposentadoria ou de abono de permanência em serviço), e desde que o último salário-de-contribuição do segurado (vigente na data do recolhimento à prisão ou na data do afastamento do trabalho ou cessação das contribuições), tomado em seu valor mensal, seja igual ou inferior ao salário-de-contribuição. O benefício será equivalente a 100\% (cem por cento) do salário-de-benefício que o segurado recebia ou teria recebido se estivesse aposentado por invalidez na data da detenção ou prisão.

Existem também os benefícios aplicáveis tanto aos segurados quanto aos dependentes. São os serviços sociais, voltados aos segurados em benefício por incapacidade temporária, bem como aos aposentados e pensionistas, sendo mais uma forma de esclarecer junto aos beneficiários seus direitos sociais; e a reabilitação profissional, que visa proporcionar ao beneficiário incapacitado parcial ou totalmente, e às pessoas com deficiência, os meios para a (re)educação e de (re)adaptação profissional e social indicados para participar do mercado de trabalho e do contexto em que vive.

Como se pode verificar, as prestações previdenciárias são calculadas, via de regra, com base no salário-de-benefício, exposto a seguir. 


\subsubsection{Do cálculo do benefício}

Nos termos da Lei de Benefícios, o valor do benefício de prestação continuada, inclusive o regido por norma especial e o decorrente de acidente do trabalho, exceto o salário-família e o salário-maternidade, será calculado com base no salário-de-benefício.

Nesse sentido, para os filiados à Previdência Social após 28/11/1998 ${ }^{31}$, entende-se por saláriode-benefício, para fins de cálculo da renda mensal da Aposentadoria por Idade e da Aposentadoria por Tempo de Contribuição, a média aritmética simples dos maiores saláriosde-contribuição correspondentes a $80 \%$ (oitenta por cento) de todo o período contributivo, multiplicada $^{32}$ pelo fator previdenciário ${ }^{33}$. De forma diversa, aplica-se para a Aposentadoria por Invalidez, Aposentadoria Especial, Auxílio-doença e Auxílio-acidente a média aritmética simples dos maiores salários-de-contribuição correspondentes a $80 \%$ (oitenta por cento) de todo o período contributivo.

Destaque-se que o salário-de-benefício não poderá ser inferior ao de um salário mínimo, nem superior ao teto do salário-de-contribuição na data de início do benefício.

Outra regra é aplicável aos filiados à Previdência Social até 28/11/1998 ${ }^{34}$, quando se entende por salário-de-benefício a média aritmética simples dos maiores salários-de-contribuição correspondentes a $80 \%$ (oitenta por cento) do período contributivo desde a competência julho de 1994.

\footnotetext{
${ }^{31}$ Aplica-se aqui o art. 32 do Decreto ${ }^{\circ} 3.048 / 99$.

${ }^{32}$ Como já colocado, o aposentado por idade não é obrigado a aplicar o fator previdenciário, caso este lhe seja menos favorável, como prevê o art. 181-A do Decreto n³ 3.048/99.

${ }^{33} \mathrm{O}$ fator previdenciário será calculado com base na idade, na expectativa de sobrevida e no tempo de contribuição do segurado ao se aposentar, segundo a fórmula determinada pela Lei $n^{\circ}$ 9.876/99:

Fator Previdenciário: Tc X a / Es X [1 + (Id + Tc X a ) / 100], onde:

Tc = tempo de contribuição até o momento da aposentadoria;

Es = expectativa de sobrevida no momento da aposentadoria;

Id = idade no momento da aposentadoria;

$a=$ alíquota de contribuição correspondente a 0,31 .

Note-se ainda que essa expectativa de sobrevida do segurado na idade da aposentadoria será obtida a partir da tábua completa de mortalidade construída pela Fundação Instituto Brasileiro de Geografia e Estatística (IBGE), considerando-se a média nacional única para ambos os sexos.

${ }^{34}$ Para estes casos, aplica-se o art. 188-A do Decreto ${ }^{\circ} 3.048 / 99$.
} 
Para esses filiados, o cálculo da renda mensal das Aposentadorias por Idade, Tempo de Contribuição e Especial utilizará um divisor não inferior a $60 \%$ (sessenta por cento) do período decorrido desde a competência julho de 1994 até a data de início do benefício, limitado a $100 \%$ de todo o período contributivo ${ }^{35}$. Neste caso, o fator previdenciário será aplicado de forma progressiva ${ }^{36}$.

Nos casos de Auxílio-Doença e de Aposentadoria por Invalidez, o salário-de-benefício corresponderá à média aritmética simples dos maiores salários-de-contribuição correspondentes a $80 \%$ (oitenta por cento) do período contributivo decorrido desde a competência julho de 1994 até a data do início do benefício.

Não havendo contribuições a partir de julho de 1994, o valor de benefício será de um salário mínimo ${ }^{37}$.

O INSS, por sua vez, dispõe do prazo de 180 (cento e oitenta) dias, contados a partir da solicitação do pedido do benefício, para fornecer as informações constantes do Cadastro Nacional de Informações Sociais - CNIS sobre as contribuições e remunerações dos segurados utilizadas no cálculo do salário-de-benefício.

\subsubsection{Das contribuições sociais previdenciárias}

Como já mencionado anteriormente quando abordado o financiamento da Seguridade Social, mais especificamente quanto à Previdência Social, tanto os indivíduos trabalhadores quanto as empresas empregadoras de trabalhadores devem contribuir para o custeio de todo o sistema, diante de seu caráter contributivo.

\footnotetext{
${ }^{35}$ Conforme prevê o $\S 1^{\circ}$ do art. 188-A do Decreto ${ }^{\circ} 3.048 / 99$. Em outras palavras, se o segurado contar com menos de $60 \%$ (sessenta por cento) de contribuições, no período decorrido de julho de 1994 até a presente data, o divisor a ser considerado no cálculo da média aritmética simples será sempre $60 \%$ (sessenta por cento).

Contando o segurado com $60 \%$ (sessenta por cento) a $80 \%$ (oitenta por cento) de contribuições no período decorrido de julho de 1994 até a presente data, será utilizado como divisor o percentual correspondente ao total de contribuições.

${ }^{36}$ Nos termos do $\S 2^{\circ}$ do art. 188-A do Decreto n ${ }^{\circ} 3.048 / 99$, o fator previdenciário incidirá sobre um sessenta avos da referida média aritmética, por competência que se seguir a 28/11/1999, cumulativa e sucessivamente, até completar sessenta sessenta avos da referida média, na competência novembro de 2004.

${ }^{37}$ Conforme o art. 188 -E do Decreto ${ }^{\circ} 3.048 / 99$.
} 
A contribuição previdenciária do empregado, inclusive o doméstico, bem como do trabalhador avulso é calculada mediante a aplicação de uma alíquota sobre o seu salário-de-contribuição mensal, de forma não cumulativa, seguindo uma tabela de contribuição mensal própria. Aplica-se outra tabela para os contribuintes individuais ${ }^{38}$ e os facultativos ${ }^{39}$. Ambas as tabelas são atualizadas regularmente por uma portaria interministerial MPS/MF.

Por seu turno, a contribuição a cargo da empresa e de outros tipos de empregadores é em regra equivalente a $20 \%$ (vinte por cento) ${ }^{40}$ sobre o total das remunerações pagas, devidas ou creditadas a qualquer título, durante o mês, aos segurados empregados e trabalhadores avulsos que lhe prestem serviços, destinadas a retribuir o trabalho, qualquer que seja a sua forma (inclusive as gorjetas, os ganhos habituais sob a forma de utilidades e os adiantamentos decorrentes de reajuste salarial, quer pelos serviços efetivamente prestados, quer pelo tempo à disposição do empregador ou tomador de serviços, nos termos da lei ou do contrato ou, ainda, de convenção ou acordo coletivo de trabalho ou sentença normativa).

Excepcionalmente, para o financiamento da Aposentadoria Especial e daqueles concedidos em razão do grau de incidência de incapacidade laborativa decorrente dos riscos ambientais do trabalho, sobre o total das remunerações pagas ou creditadas, no decorrer do mês, aos segurados empregados e trabalhadores avulsos, estão previstas as alíquotas ${ }^{41}$ de (i) $1 \%$ (um por cento) para as empresas em cuja atividade preponderante o risco de acidentes do trabalho seja considerado leve; (ii) $2 \%$ (dois por cento) para as empresas em cuja atividade preponderante esse risco seja considerado médio; e (iii) 3\% (três por cento) para as empresas em cuja

\footnotetext{
${ }^{38}$ Para os quais é considerada a remuneração auferida em uma ou mais empresas ou pelo exercício de sua atividade por conta própria, durante o mês, observados os limites mínimo e máximo do salário-de-contribuição.

${ }^{39}$ Considerados os valores por eles declarados, também observados os limites mínimo e máximo do salário-decontribuição.

${ }^{40}$ Acrescido de 2,5\% (dois vírgula cinco por cento), no caso de bancos comerciais, bancos de investimentos, bancos de desenvolvimento, caixas econômicas, sociedades de crédito, financiamento e investimento, sociedades de crédito imobiliário, sociedades corretoras, distribuidoras de títulos e valores mobiliários, empresas de arrendamento mercantil, cooperativas de crédito, empresas de seguros privados e de capitalização, agentes autônomos de seguros privados e de crédito e entidades de previdência privada abertas e fechadas.

${ }^{41}$ Estas alíquotas correspondem à chamada tarifação coletiva. Na prática, o Fator Acidentário de Prevenção (FAP) é um multiplicador, que varia de 0,5 a 2 pontos, a ser aplicado às alíquotas de $1 \%, 2 \%$ ou $3 \%$ da tarifação coletiva por subclasse econômica. A base de cálculo do FAP varia anualmente, calculada sempre sobre os dois últimos anos de todo o histórico de acidentalidade e de registros acidentários da Previdência Social, por empresa. O fator incide sobre as alíquotas das empresas que são divididas em 1.301 subclasses da Classificação Nacional de Atividade Econômica (CNAE 2.0).
} 
atividade preponderante esse risco seja considerado grave. É o chamado Fator Acidentário de Prevenção (FAP).

São igualmente aplicáveis ao empregador em geral as alíquotas de $20 \%$ (vinte por cento) ${ }^{42}$ sobre o total das remunerações pagas ou creditadas a qualquer título, no decorrer do mês, aos segurados contribuintes individuais que lhe prestem serviços; $15 \%$ (quinze por cento) sobre o valor bruto da nota fiscal ou fatura de prestação de serviços, relativamente a serviços que lhe são prestados por cooperados, por intermédio de cooperativas de trabalho; e 12\% (doze por cento) do salário-de-contribuição do empregado doméstico a seu serviço.

Está prevista a incidência da contribuição a 2,5\% (dois vírgula cinco por cento) sobre o total da receita bruta proveniente da comercialização da produção rural, quando se tratar de pessoa jurídica que tenha como fim apenas a atividade de produção rural (em substituição à contribuição de $20 \%$ sobre o total das remunerações de empregados), mais $0,1 \%$ de contribuição para o financiamento da Aposentadoria Especial e daqueles benefícios concedidos em razão do grau de incidência de incapacidade para o trabalho decorrente dos riscos ambientais da atividade.

Finalmente, está prevista também a incidência de 5\% (cinco por cento) de contribuição sobre a renda bruta dos espetáculos desportivos da associação desportiva que mantém equipe de futebol profissional incidente sobre a receita bruta decorrente de espetáculos desportivos e de qualquer forma de patrocínio, de licenciamento de uso de marcas e símbolos, de publicidade, de propaganda e transmissão de espetáculos.

\footnotetext{
${ }^{42}$ Também acrescido de 2,5\% (dois vírgula cinco por cento), no caso de bancos comerciais, bancos de investimentos, bancos de desenvolvimento, caixas econômicas, sociedades de crédito, financiamento e investimento, sociedades de crédito imobiliário, sociedades corretoras, distribuidoras de títulos e valores mobiliários, empresas de arrendamento mercantil, cooperativas de crédito, empresas de seguros privados e de capitalização, agentes autônomos de seguros privados e de crédito e entidades de previdência privada abertas e fechadas.
} 


\subsubsection{Da proteção aos trabalhadores desempregados}

Não obstante o RGPS, nos termos do $\S$ único do art. $6^{\circ}$ do Decreto ${ }^{\circ} 3.048 / 99$, tenha deixado de acobertar o trabalhador em situação de desemprego involuntário, faz-se necessário mencionar abaixo dois programas importantes voltados à proteção destes trabalhadores.

Garantida constitucionalmente (art. $7^{\circ}$, II da CF/88), o Programa Seguro-Desemprego foi criado pela Lei $\mathrm{n}^{\circ} 7.998 / 90$ com a finalidade de prover assistência financeira temporária a trabalhadores demitidos sem justa causa, bem como assisti-los na recolocação profissional por meio de ações integradas. É custeado pelo Fundo de Amparo ao Trabalhador (FAT), cujos recursos são constituídos em parte pela arrecadação de contribuições recolhidas para o Programa de Integração Social (PIS) e ao Programa de Formação do Patrimônio do Servidor Público (PASEP).

A assistência financeira é concedida, dependendo da duração do vínculo empregatício do trabalhador, em três até, no máximo, cinco parcelas, de forma alternada ou contínua, a cada período aquisitivo de dezesseis meses. Esta parcela é calculada com base no salário médio do trabalhador nos últimos três meses anteriores à dispensa.

Também uma garantia constitucional (art. $7^{\circ}$, III da CF/88), o Fundo de Garantia do Tempo de Serviço (FGTS) foi criado pela Lei $n^{\circ} 5.107 / 66$ e é atualmente disciplinado pela Lei $\mathrm{n}^{\circ}$ 8.036/90. Todo mês o empregador deve depositar o equivalente a $8 \%$ da remuneração do empregado em uma conta vinculada ao seu contrato de trabalho e administrada pela Caixa Econômica Federal.

Ocorrendo a rescisão do contrato de trabalho motivada por demissão sem justa causa, o empregador deverá depositar o equivalente a $40 \%$ do montante de todos os depósitos realizados na conta vinculada durante a vigência do contrato de trabalho, atualizados monetariamente acrescidos dos respectivos juros. A conta poderá ser movimentada não apenas quando o empregado for demitido sem justa causa, mas também quando este se aposentar pelo INSS, adquirir moradia própria ou vier a falecer (quando o saque será feito por seus 
dependentes), entre outras hipóteses. O FGTS garante, dessa forma, nada menos que o patrimônio do trabalhador.

\subsection{Assistência Social}

Diferentemente da previdência social, a assistência social é a política de seguridade social não contributiva, financiada com os recursos do orçamento da seguridade social e organizada com a participação da população na formulação de políticas e no controle das ações em todos os níveis, conforme previsão nos artigos 203 e 204 da Constituição Federal.

As políticas de assistência social têm vistas a (i) proteger a família, a maternidade, a infância, a adolescência e a velhice, (ii) amparar as crianças e adolescentes carentes, (iii) promover a integração no mercado de trabalho, (iv) habilitar e reabilitar as pessoas com deficiências e à promoção de sua integração à vida comunitária e, também, (v) garantir um salário mínimo mensal à pessoa com deficiência e ao idoso que comprovem não possuir meios de prover a sua própria subsistência ou meios de sua família provê-la.

Este dispositivo constitucional foi regulamentado pela Lei $\mathrm{n}^{\circ}$ 8.742/93, a Lei Orgânica da Assistência Social (LOAS), que inclusive prescreveu a supremacia do atendimento às necessidades sociais sobre as exigências da ordem econômica (previstas pelo art. 170 da Constituição Federal). Inclusive, a ordem econômica deve levar em consideração a valorização do trabalho humano e a livre iniciativa, a fim de assegurar a todos uma existência digna, nos conformes da justiça social.

Ademais, a assistência social deve primar pela universalização dos direitos sociais, pelo respeito à dignidade e à autonomia do cidadão (que não deve ser exposto a situações vexatórias para poder usufruir da assistência), pela igualdade de direitos (sem qualquer forma de discriminação), bem como pela divulgação ampla dos benefícios, serviços, programas, projetos assistenciais e dos recursos oferecidos e critérios de concessão. 
A partir do momento em que o indivíduo comprove se encontrar em estado de necessidade causado por uma contingência social, ele se torna automaticamente qualificado ao atendimento pelo órgão assistente.

O financiamento da assistência social se dá através do Fundo Nacional de Assistência Social (FNAS), que deve repassar os recursos destinados à cobertura das despesas relacionadas à assistência social, observadas as condições de comprovação do orçamento destinado especificamente ao Fundo (como previsto pelo art. 195 da Constituição Federal, analisado mais abaixo).

Note-se que, embora os recursos de responsabilidade da União para o financiamento dos benefícios da prestação continuada possam ser repassados diretamente pelo Ministério do Desenvolvimento Social e Assistência Social ao Instituto Nacional de Seguridade Social (INSS), órgão responsável por sua execução e manutenção, não cabe à previdência social o financiamento das prestações sociais.

Por sua vez, a gestão das ações na área de assistência social fica organizada sob a forma de um sistema descentralizado e participativo, denominado Sistema Único de Assistência Social (SUAS), cujo objetivo principal é consolidar a gestão compartilhada, o financiamento e a cooperação técnica entre os entes federativos para fins de operação da proteção social não contributiva.

Quanto aos benefícios assistenciais, estes não são nominados e podem ser prestados de forma continuada ou eventual, como abordados em seguida.

- Benefício da Prestação Continuada (BPC-LOAS) - é garantido um salário-mínimo mensal à pessoa com deficiência ${ }^{43}$ e ao idoso com mais de 65 (sessenta e cinco anos)

\footnotetext{
${ }^{43}$ Nos termos do art. 20, parágrafo $2^{\circ}$ da LOAS, considera-se pessoa com deficiência aquela que tem impedimentos de longo prazo de natureza física, mental, intelectual ou sensorial, os quais, em interação com diversas barreiras, podem obstruir sua participação plena e efetiva na sociedade em igualdade de condições com as demais pessoas. A condição e o seu grau de impedimento são avaliados por médicos e assistentes sociais do INSS.
} 
que comprovem não possuir meios ou família ${ }^{44}$ aptos a prover sua subsistência. É considerada incapaz de manter a subsistência do idoso ou do deficiente a família cuja renda per capita mensal seja inferior a $1 / 4$ (um quarto) do salário-mínimo. Vale ressaltar que o BPC não pode ser acumulado pelo beneficiário com qualquer outro no âmbito da seguridade social ou de outro regime, salvo os da assistência médica e da pensão especial de natureza indenizatória. As condições de recebimento do BPC devem ser sujeitas à avaliação a cada 02 (dois) anos, pois, se superadas, é cessado o pagamento ${ }^{45}$, inclusive quando do falecimento ${ }^{46}$ do beneficiário.

- Benefício Eventual - trata-se das provisões suplementares e provisórias que integram organicamente as garantias do SUAS e são prestadas aos cidadãos e às famílias em virtude de nascimento, morte, situações de vulnerabilidade temporária e de calamidade pública.

Além dos benefícios, também estão previstos os serviços socioassistenciais, referentes às atividades continuadas que visam à melhoria de vida da população e cujas ações são voltadas para as necessidades básicas, guardados os objetivos, princípios e diretrizes da assistência social.

Para tanto, são criados programas de amparo voltados à proteção de crianças e adolescentes sob risco pessoal e social, além das pessoas moradoras de rua, dentre outros programas. Esses Programas de Assistência Social devem priorizar a inserção profissional e social. Se voltados aos idosos e pessoas com deficiência, deverão ser especialmente articulados com o BPC.

Com tais finalidades, a LOAS criou o Serviço de Proteção e Atendimento Integral à Família (PAIF), para famílias em situação de vulnerabilidade social, o Serviço de Proteção e Atendimento Especializado a Famílias e Indivíduos (PAEFI), para famílias e indivíduos em

\footnotetext{
${ }^{44}$ Para esses fins, a família é composta pelo requerente, o cônjuge ou companheiro, os pais e, na ausência de um deles, a madrasta ou o padrasto, os irmãos solteiros, os filhos e enteados solteiros e os menores tutelados, desde que vivam sob o mesmo teto (art. 20, parágrafo $1^{\circ}$ da LOAS).

${ }^{45}$ Há outros fatores que podem extinguir o pagamento do BPC, como a identificação de irregularidades na sua concessão ou utilização. Da mesma forma, é suspenso o pagamento quando a pessoa com deficiência passa a exercer atividade remunerada.

${ }^{46} \mathrm{O}$ benefício assistencial é intransferível e, portanto, não gera pensão aos dependentes.
} 
situação de ameaça ou violação de direitos, mais o Programa de Erradicação do Trabalho Infantil (PETI), para crianças e adolescentes que se encontrem em situação de trabalho.

Por fim, também estão previstos os projetos de enfrentamento da pobreza, que devem fomentar o investimento econômico-social nos grupos populares, buscando subsidiar, financeira e tecnicamente, iniciativas que lhes garantam meios, capacidade produtiva e de gestão para melhoria das condições gerais de subsistência, elevação do padrão da qualidade de vida, a preservação do meio ambiente e sua organização social.

Um dos programas de destaque mais recentes é o Bolsa Família ${ }^{47}$, estabelecido pela Lei ${ }^{\circ}$ 10.836/04. Seu objetivo é transferir renda de forma direta a fim de aliviar imediatamente a extrema pobreza e promover o acesso das famílias de baixa renda à educação, saúde e assistência social. Na verdade, o Bolsa Família unificou a gestão de outros programas (o Bolsa Escola, Cartão Alimentação e o Bolsa Alimentação) por meio de um conselho gestor, presidido pelo Ministério do Desenvolvimento Social e Combate à Fome. As famílias beneficiadas são selecionadas com base nas informações registradas pelo município no Cadastro Único para Programas Sociais do Governo Federal.

\footnotetext{
${ }^{47}$ Fonte: http://www.mds.gov.br/bolsafamilia
} 


\section{CAPÍTULO III - CONTEXTO HISTÓRICO, ECONÔMICO E SOCIAL DA EVOLUÇÃO DA SEGURIDADE SOCIAL NO JAPÃO}

1. O cenário econômico do Japão e suas influências sobre o mercado de trabalho

Para falar da evolução da seguridade social no Japão, é preciso primeiro compreender o próprio contexto histórico, econômico e social em que estão inseridos os trabalhadores japoneses e suas famílias, antes mesmo de tratar da proteção de seus direitos sociais.

No início dos anos 80 o Japão experimentou uma valorização do iene e, no final daquela década, uma bolha especulativa envolvendo os preços dos ativos manteve as taxas de crescimento econômico mais altas do que eram de fato.

Seu banco central, preocupado com esse crescimento artificial, ao verificar que as empresas investidoras em ações e propriedades imobiliárias haviam se endividado excessivamente, viuse obrigado a tomar medidas de controle que acabaram por prejudicar os balanços dessas empresas. Os bancos comerciais, por sua vez, ao mesmo tempo em que hesitavam conceder novos empréstimos às empresas, recearam uma onda generalizada de falências (o que teria agravado ainda mais a situação de desemprego), mantendo os empréstimos. Estes foram os principais fatores que ocasionaram o estouro dessa bolha especulativa.

Após o colapso dessa bolha no final dos anos 80, a década de 1992 a 2002 testemunhou mudanças adversas no desempenho da economia do Japão, tendo a taxa de crescimento diminuído drasticamente de 3-4\% para apenas $1 \%$ nos anos 90 , cenário conhecido como a "década perdida".

De fato, a crise financeira no final dos anos 90 gerou desemprego e estagnação não vistos desde a Segunda Guerra Mundial. A taxa de desemprego desde o período Pós-Guerra, que oscilava entre $2-3 \%$, chegou ao dobro.

Muito criticada por observadores ocidentais, que entendiam como sendo um contrassenso e até mesmo resquício da sociedade feudal, a tradicional estrutura laboral japonesa, até então 
baseada em um emprego único para toda a vida (shushin koyo), sofreu rupturas profundas decorrentes dessa crise econômica, quando os trabalhadores foram obrigados a buscar novos empregos ou simplesmente aceitar posições temporárias, quando existiam.

Lentamente a empregabilidade crescia e o mercado de trabalho se recuperava, até que sobreveio a crise global de 2008, quando o Japão sofreu a mais grave recessão de sua história desde a Segunda Guerra. Em 2009, tanto o número de empregos quanto as horas trabalhadas e os salários despencaram, tendo o nível de desemprego alcançado 5,6\%, até diminuir em 2010 para $5 \%$.

Em face do cenário exposto, pode-se verificar que, diante da lenta recuperação do mercado de trabalho do Japão da crise econômica de 2008, o sistema de proteção social japonês está lidando na atualidade com uma demanda sem precedentes por parte de toda a sociedade afetada.

2. Aspectos jurídicos trabalhistas no Japão: a posição das cortes com relação à demissão de empregados

A legislação trabalhista japonesa fora consolidada somente no Pós-Guerra, durante a ocupação norte-americana, não oferecendo à época significativa proteção aos trabalhadores, com exceção do aviso prévio (comunicação de desligamento com 30 dias de antecedência). Apesar disso, a Constituição Japonesa previu o direito ao trabalho (Artigo 27) e aos chamados "padrões mínimos de vida sã e instruída" (Artigo 25), nos quais se basearam as cortes japonesas para justificar a equiparação dos níveis de proteção ao trabalho aos padrões exigidos pela OCDE.

É claro que tais dispositivos legais não protegiam os empregados de forma completa, pois, na prática, os processos trabalhistas eram custosos e demoravam muito para ser apreciados. Além disso, muitos empregados sofriam assédio moral de seus empregadores, acabando por preferir se aposentar ou se demitir voluntariamente ao invés de entrar em litígio. 
E foram sob tais circunstâncias que as cortes japonesas adotaram a chamada "Doutrina da Demissão Abusiva", segundo a qual existiriam duas formas de demissão, a normal e a econômica. A normal acontecia por razões individuais, relacionadas ao próprio empregado, ao passo que a demissão econômica ocorria em razão de circunstâncias envolvendo a própria condição do empregador de prover empregos.

Nesse particular, a Suprema Corte do Japão decidiu da seguinte maneira em 1975: "mesmo quando um empregador exerce seu direito de demitir, este fato poderá ser reconhecido como um abuso de direito caso não tenha sido embasado em razões objetivas, não tendo sido aprovado socialmente como um ato apropriado"48.

Dessa forma, ainda que um trabalhador seja demitido por razões ditas normais, o término unilateral de um contrato de trabalho por prazo indeterminado deve observar outras condições, quais sejam, razão objetiva e aprovação social. Além do mais, os tribunais poderiam solicitar aos réus (empregadores, nos casos de discussão sobre demissão) para comprovar em juízo que não houve abuso de direitos. Por conta das dificuldades maiores que o empregado teria para comprovar as verdadeiras intenções do empregador, essa inversão do ônus da prova é um dos aspectos mais importantes dessa doutrina.

Os conceitos "razão objetiva" e "aprovação social" foram melhor ilustrados no primeiro caso a versar sobre demissão econômica, Caso Shimazaki vs. Toyo Sanso de $1979^{49}$, julgado pela Alta Corte de Tóquio. Segundo prolatado, há quatro condições para esse tipo de demissão:

- O empregador deve apresentar justificativas objetivas para reduzir sua quantidade de empregados;

- A demissão deve ser o último dos recursos disponíveis;

- Devem ser adotados critérios objetivos para escolher aqueles que serão dispensados;

- O procedimento de demissão deve ser coerente.

\footnotetext{
48 Julgado em 25/04/1975, Caso Ichikawa vs. Nihon Shokuen Seizo Co., Suprema Corte, vol. 29, Minshu, pp.456-458, cit. por Ryo Kambayashi, Dismissal Regulation in Japan.

${ }^{49}$ Alta Corte de Tóquio, 29/10/1979, Ro Minshu, p. 1002., cit. por Ryo Kambayashi, Dismissal Regulation in Japan.
} 
Trata-se de uma maneira de estabelecer um padrão considerado razoável para as demissões, que passaram a ser vistas como justificáveis somente se efetuadas dentro dessas circunstâncias.

O mais interessante é a constatação de que os tribunais seguiram rigorosamente esse entendimento na última década, em face da alteração da Lei de Relações Trabalhistas em 2004, cujo artigo 18-2 passou a dispor: "a demissão desacompanhada de razões objetivas e aprovação social será considerada como sendo um mau uso do direito e inválida". Desde então, a jurisprudência japonesa tem mantido esse entendimento.

3. A migração dos trabalhadores estrangeiros para o Japão, com destaque para os brasileiros

A fim de suprir a demanda do mercado de trabalho japonês por mão-de-obra, deu-se início ao fenômeno migratório dos anos 80, quando trabalhadores estrangeiros, inclusive brasileiros, foram atraídos pelas oportunidades atraentes de emprego no país.

Contudo, a permanência destes trabalhadores não era permitida pela Lei de Controle de Imigração e de Refugiados, já que esta só permitia a entrada de pessoas atuantes em determinadas categorias profissionais como diplomatas, professores, engenheiros, pesquisadores, estudantes, dentre outros, excluindo os trabalhadores considerados não qualificados.

Tal lei foi alterada em 1989, com vigência a partir de 1990, criando a categoria dos "residentes por longo período", à qual pertenciam os descendentes de japoneses de segunda e terceira geração (nissei e sansei), não contendo restrições quanto às atividades profissionais que poderiam realizar. Aos nissei era concedido o visto para três anos e aos sansei o visto para um ano, renováveis por igual período. Foi graças a essa reforma legislativa que os trabalhadores brasileiros descendentes de japoneses, seus cônjuges (descendentes ou não de japoneses) e filhos puderam permanecer legalmente no Japão para trabalhar. 
Segundo o Ministério da Saúde, Trabalho e Bem-Estar Social do Japão (MHLW), os trabalhadores brasileiros representam atualmente um contingente estimado de $18 \%$ dos trabalhadores estrangeiros no Japão:

Trabalhadores estrangeiros no Japão, distribuídos conforme a nacionalidade (dados de Outubro de $2010^{50}$ )

\begin{tabular}{|c|c|c|}
\hline Chineses & $44,17 \%$ & 287.105 \\
\hline Brasileiros & $\mathbf{1 7 , 9 0 \%}$ & $\mathbf{1 1 6 . 3 6 3}$ \\
\hline Filipinos & $9,49 \%$ & 61.710 \\
\hline Coreanos & $4,45 \%$ & 28.921 \\
\hline Peruanos & $3,59 \%$ & 23.360 \\
\hline Outros & $20,39 \%$ & 132.523 \\
\hline Total de trabalhadores \\
estrangeiros
\end{tabular}

Nesse contexto, é necessário deixar registrado que a situação legal de significativa parte dos trabalhadores brasileiros no Japão é considerada instável, tendo em vista a estimativa de que $60 \%$ desse contingente tenha sido contratado indiretamente pelas empresas japonesas, por meio de empreiteiros, o que fragiliza o vínculo entre o trabalhador e a empresa, além de deixálo vulnerável às questões trabalhistas e de seguridade social, pois o contrato de trabalho é muitas vezes irregular e não são devidamente recolhidas as contribuições previdenciárias em nome do trabalhador.

\footnotetext{
${ }^{50}$ Fonte: "Relatório sobre a situação do trabalhador estrangeiro - Outubro de 2010”, elaborado pelo Ministério da Saúde, Trabalho e Bem-Estar Social do Japão (MHLW), apresentado em palestra de Mari Yamamoto, Diretora da Divisão de Políticas para Contratação de Estrangeiros da Secretaria de Segurança do MHLW, durante o Simpósio dos Colaboradores do Centro de Informação e Apoio ao Trabalhador Estrangeiro (CIATE) em 06/11/2011, em São Paulo/SP.
} 
4. A seguridade social no Japão nesse contexto de mudanças

De maneira semelhante a outros países, o sistema de seguridade social do Japão encontrou suas bases na prestação de serviços de assistência aos pobres. O intervalo entre a Era Meiji (1868-1912) e a Segunda Guerra Mundial testemunhou a implementação de medidas legais de assistência aos pobres (Lei de Amparo aos Indigentes de 1884, Lei de Amparo aos Pobres de 1929) e a introdução de um sistema de seguro social (edição das Leis de Seguro Saúde de 1927, do Seguro Saúde Nacional de 1938 e da Aposentadoria de 1941). Entretanto, esses sistemas eram considerados inadequados em termos de acesso pela população.

Por outro lado, o sistema de seguridade social do Japão evoluiu consideravelmente após o fim da Segunda Guerra Mundial. Durante o período de turbulência social que se seguiu, medidas de assistência aos necessitados, de combate à desnutrição e de prevenção de doenças foram adotadas, ao mesmo tempo em que a infraestrutura aplicada a essas políticas foi melhorada. A nova Constituição, promulgada em 1947, prevê em seu Artigo 25 os princípios fundamentais do desenvolvimento de um sistema de seguridade social, nos quais se basearam as leis relacionadas à proteção social, editadas no período pós-guerra. Foram editadas a Lei do BemEstar Infantil (1947) e a Lei de Bem-Estar para as Pessoas com Deficiências Físicas (1949), seguidas por uma nova Lei de Assistência Pública (1950) e pela Lei do Serviço Social (1951).

Paralelamente, o Japão alcançou um rápido crescimento econômico nesse período pós-guerra, tornando-se um país desenvolvido, enquanto experimentava diversas mudanças sociais, a principal delas de fator demográfico. A população certamente cresceu em números absolutos logo após o fim da Segunda Guerra, mas também envelheceu. Recentemente, para agravar a situação, as baixas taxas de natalidade acabaram por levar ao encolhimento da população jovem.

Nessa evolução pós-guerra, a política da "cobertura universal” finalmente estendeu o Seguro Saúde e a Aposentadoria Pública a toda a população em 1961. Foram editadas também a Lei do Bem-Estar do Idoso e as Leis do Bem-Estar Materno e Infantil, tendo sido também implantados vários outros benefícios sociais. Durante o período de estabilidade econômica, o 
sistema de seguridade social chegou a ser revisado no final dos anos 70 . Atender a população em acelerado envelhecimento tornou-se um desafio.

Também foram verificadas alterações nas estruturas familiares (por exemplo, o surgimento de famílias com membros idosos apenas e outras monoparentais), bem como nas estruturas de emprego (aumento do número de empregados, inclusive estrangeiros), com o avanço das mulheres no mercado de trabalho e a urbanização da população. Em face dessas alterações, a proteção social dos idosos, das novas estruturas familiares, das pessoas com deficiência e dos desempregados requer cada vez maior atenção.

Acompanhando essa evolução do sistema de proteção social do Japão, o país ratificou em 1976 a Convenção $\mathrm{n}^{\circ} 102$ da OIT, que estabelece os padrões mínimos de seguridade social. Na ocasião, foram recepcionadas as Partes III a VI ${ }^{51}$ (assistência em caso de adoecimento, desemprego, idade avançada e acidentes de trabalho) dessa Convenção.

Nos anos 90, os sistemas de Seguro Saúde e de Pensão foram reformados e a Lei do Seguro para Assistência a Longo Prazo foi editada, com foco no atendimento da população idosa.

O próprio Ministério da Saúde, Trabalho e Bem-Estar Social do Japão reconhece que o envelhecimento da população e o declínio das taxas de natalidade do país têm direcionado as reformas legislativas no sentido de incentivar a participação de jovens, mulheres, idosos e pessoas com deficiência no mercado de trabalho ${ }^{52}$. São algumas dessas questões, portanto, que configuram parte das novas demandas da sociedade japonesa, com as quais o presente sistema de seguridade social do Japão precisa lidar.

\footnotetext{
${ }^{51}$ A Parte VI dessa Convenção não é mais aplicável, tendo sido derrogada pela Convenção no 121 da OIT, que trata da Assistência em caso de Acidentes de Trabalho.

${ }^{52}$ Fonte: Apresentação do MHLW em http://www.mhlw.go.jp/english/policy/employ-labour/labourpolicy/dl/director-general_for_policy.pdf (acesso em 05/01/14).
} 


\section{CAPÍTULO IV - DA SEGURIDADE SOCIAL NO JAPÃO}

1. Da terminologia utilizada na literatura estrangeira quanto à seguridade social do Japão

Previamente à abordagem da seguridade social do Japão, cabe tecer alguns comentários preliminares sobre a terminologia utilizada, dado o fato das fontes de pesquisa consultadas para desenvolver este tópico consistirem quase que exclusivamente em textos originalmente escritos nas línguas japonesa e inglesa, ocasionando certos enfrentamentos delicados na versão dos termos para o vernáculo.

O primeiro comentário é dedicado ao termo pension utilizado em National Pension System e em Employees’ Pension Insurance System pelo Governo Japonês ${ }^{53}$. Na língua inglesa, designa uma soma paga regularmente a um indivíduo, sob condições ligadas à sua aposentadoria ou, ainda, quantia paga a seus dependentes sobreviventes ${ }^{54}$, podendo também se referir a um pagamento regular efetuado a indivíduo que contribuiu para um plano de aposentadoria individual $^{55}$.

\footnotetext{
${ }^{53}$ Fonte: http://www.nenkin.go.jp/n/www/english/index.jsp

${ }^{54}$ Fonte: Dicionário Merriam-Webster (www.m-w.com) the completion of an agreed span of service. The payments generally continue for the rest of the recipient's natural life, and they are sometimes extended to a widow or other survivor. Military pensions have existed for many centuries; private pension plans originated in Europe in the 19th century. There are two basic types of pension plans: defined contribution and defined benefit. A defined contribution plan invests a defined amount each pay period. The individual may have some discretion as to how the money is invested. The benefit, the amount of the pension, depends on the success of those investments. A defined benefit plan pays a known amount according to some formula, but the amount invested in the fund may vary. Pensions may be funded by making payments into a pension TRUST FUND or by the purchase of ANNUITIES from insurance companies. In plans known as multiemployer plans, various employers contribute to one central trust fund administered by a joint board of trustees."

${ }^{55}$ Fonte: Dicionário Collins Concise Harper Collins Publishers (www.wordreference.com) "pension /'pen/an/N

1. a regular payment made by the state to people over a certain age to enable them to subsist without having to work

2. a regular payment made by an employer to former employees after they retire
} 
No idioma japonês é referido como 年金 ${ }^{56}$ (nenkin).

Em língua portuguesa, a palavra "pensão" é definida como sendo uma renda paga regularmente pelo Estado ou particular a alguém (ou seus herdeiros) por serviços prestados ou por mera liberalidade ${ }^{57}$.

Desse modo, optou-se por traduzir neste trabalho National Pension System por Sistema Nacional de Aposentadoria (em lugar de "Sistema Nacional de Pensão"), por se entender que o termo "aposentadoria" designaria melhor o instituto em questão como um todo, não se referindo apenas à renda paga regularmente ("pensão") ${ }^{58}$.

Em japonês, o termo aposentadoria é referido como 退職 ${ }^{59}$ (taishoku).

Por aposentadoria compreende-se o direito de receber uma mensalidade, conferido ao empregado que se retira do serviço após anos de atividade ou em razão de invalidez ${ }^{60}$. Por sinal, é o termo utilizado pela OIT do Brasil na versão em português da Convenção $n^{\circ} 102$

3. a regular payment made to a retired person as the result of his or her contributions to a personal pension scheme

4. any regular payment made on charitable grounds, by way of patronage, or in recognition of merit, service, etc: a pension paid to a disabled soldier"

${ }^{56}$ Literalmente, provento anual em forma de ouro.

${ }^{57}$ Dicionário Michaelis de Português Online (http://michaelis.uol.com.br): pensão

pen.são

sf (lat. pensione) 1 Renda anual ou mensal paga, vitaliciamente ou por certo tempo, pelo Estado ou particular a alguém (ou a seus herdeiros) por serviços prestados ou por simples munificência. 2 Foro. 3 Quantia que se paga pela educação e sustento de um aluno no colégio. 4 Pequeno hotel, geralmente familiar. 5 Quantia mensal que se paga nesse pequeno hotel. 6 Fornecimento regular de comida em domicílio. 7 Encargo, obrigação, ônus. 8 Preocupação. 9 Incômodo, trabalho.

${ }^{58}$ Note-se que o Acordo Previdenciário assinado entre o Japão e o Brasil, tratado mais adiante, utiliza o termo "Pensão Nacional".

${ }^{59}$ Literalmente, deixar o emprego.

${ }^{60}$ Dicionário Michaelis de Português Online (op. cit.)

aposentadoria

a.po.sen.ta.do.ri.a

sf (aposentar+doria) 1 Ato de aposentar; aposentação, jubilação, reforma. 2Estado daquele que se aposentou. 3 Direito que tem o empregado, depois de certo número de anos de atividade ou por invalidez, de retirar-se do serviço, recebendo uma mensalidade. 4 Mensalidade que o aposentado recebe. 5Hospedagem, gasalhado. Var: aposentação. 
(Padrões Mínimos de Seguridade Social) ${ }^{61}$ em sua Parte IX - Aposentadoria por Invalidez, originalmente Invalidity benefit em inglês.

Por outro lado, Survivor's benefit (Parte X da Convenção) foi vertida para "Pensão por morte".

Na verdade, a versão original em inglês da Convenção utiliza o termo benefit para todos os tipos de benefícios de segurança social previstos, sem distinção. Do ponto de vista etimológico, benefit provém do termo latino benefactum ("fazer o bem") 62 , caracterizando modernamente um pagamento regular relacionado a um plano de aposentadoria, bem como um auxílio ligado a desemprego ou doença ${ }^{63}$. Ou seja, o termo possui sentido relativamente amplo e pode designar praticamente qualquer forma de benefício, pelo menos de acordo com a redação original da Convenção da OIT.

A tradução oficial dos termos da Convenção $\mathrm{n}^{\circ} 102$ da OIT foi apresentada da seguinte maneira:

\begin{tabular}{|l|l|l|}
\hline Convenção no 102 OIT & Língua Inglesa & Língua Portuguesa \\
\hline Parte III & Sickness benefit & Auxílio-doença \\
\hline Parte IV & Unemployment benefit & Prestações de desemprego \\
\hline Parte V & Old-age benefit & Aposentadoria por velhice \\
\hline
\end{tabular}

${ }^{61}$ http://www.oitbrasil.org.br/node/468

${ }^{62}$ Dicionário Collins Concise op. cit.: "Benefit Etymology: 14 $4^{\text {th }}$ Century: from Anglo-French benfet, from Latin benefactum, from bene facere to do well".

${ }^{63}$ Dicionário Merriam-Webster (op. cit.):

"ben'effit noun \'be-no-fit

1 archaic : an act of kindness : BENEFACTION

2 a: something that promotes well-being : ADVANTAGE; $\boldsymbol{b}$ : useful aid: HELP

$3 \boldsymbol{a}$ : financial help in time of sickness, old age, or unemployment; $\boldsymbol{b}:$ a payment or service provided for under an annuity, pension plan, or insurance policy c: a service (as health insurance) or right (as to take vacation time) provided by an employer in addition to wages or salary

4: an entertainment or social event to raise funds for a person or cause." 


\begin{tabular}{|l|l|l|}
\hline Parte VI & Employment injury benefit & $\begin{array}{l}\text { Prestações em caso de acidentes } \\
\text { de trabalho e doenças } \\
\text { profissionais }\end{array}$ \\
\hline Parte VII & Family benefit & Prestações de família \\
\hline Parte VIII & Maternity benefit & Prestações de maternidade \\
\hline Parte IX & Invalidity benefit & Aposentadoria por invalidez \\
\hline Parte X & Survivor's benefit & Pensão por morte \\
\hline
\end{tabular}

Note-se ainda que o sistema brasileiro utilizou os termos auxílio-doença, salário-maternidade e salário-família, deixando de aplicar o termo "prestação", o qual designa meramente uma contribuição ou pagamento a prazos sucessivos ${ }^{64}$.

2. A evolução do sistema de seguridade social do Japão

Como explanado anteriormente neste trabalho, o sistema de seguridade social do Japão, antes pouco desenvolvido, passou por significativas mudanças após a Segunda Guerra Mundial. No período de recuperação pós-guerra e subsequente crescimento econômico (1950-73), o governo japonês priorizou os serviços básicos de saúde e de educação, visando primordialmente à estabilização social e ao crescimento econômico. Na verdade, a seguridade social japonesa passou por uma série de adaptações à realidade do país antes de chegar ao formato contemporâneo.

Seguindo a classificação clássica de Esping-Andersen ${ }^{65}$ (1990 apud CAMPBELL, 2002), estudioso dos regimes de bem-estar social, existem três modelos de seguridade social surgidos em países ocidentais, quais sejam: (a) o "liberal-residual”, que confere tão-somente o mínimo

\footnotetext{
${ }^{64}$ Dicionário de Português Michaelis Online (op. cit.)

${ }^{65}$ ESPING-ANDERSEN, Gosta. Three Worlds of Welfare Capitalism. Princeton, New Jersey: Princeton University Press, 1990.
} 
necessário à sobrevivência dos indivíduos e do mercado, presente no Reino Unido e em países de herança britânica, como os Estados Unidos; (b) "conservador-corporativista", típico da Europa Ocidental, onde predominam Estados originalmente paternalistas; e (c) "socialdemocrático", típico de países escandinavos, preocupados em buscar o bem-estar social por meio do pleno emprego.

Embora o modelo de bem-estar social japonês não possa ser classificado com base em apenas um destes padrões, visto se tratar de uma realidade completamente diferente dos países ocidentais estudados, identificaram-se características de cada um desses três modelos em momentos diferentes da história do Japão, até se chegar ao padrão atual.

a) Período anterior à Segunda Guerra Mundial

No período anterior à Segunda Guerra, as práticas de segurança social do Japão assemelharam-se muito àqueles adotados pela Alemanha, berço do modelo ConservadorCorporativista. Em ambos os casos, o Estado se organizou institucionalmente antes do desenvolvimento da democracia parlamentarista, o que significa que houve tempo suficiente para neutralizar as potenciais pressões populares por igualdade de condições de trabalho e outras tensões sociais.

Porém, há que se apontar que, diferentemente da Alemanha, onde as organizações sindicais mantinham forte presença nas relações entre os trabalhadores e os empregadores, no Japão os sindicatos não atuavam com a mesma intensidade, o que permitiu ao governo maior liberdade para implantar e promover benefícios sociais através dessas corporações empregadoras, exatamente o núcleo do modelo "corporativista".

O que não significa que as práticas japonesas de seguridade social tenham sido tão liberais quanto aquelas dos Estados Unidos, tendo sido deixadas inteiramente a cargo das corporações. O financiamento de planos de saúde corporativos, por exemplo, embora administrado pelas próprias corporações empregadoras, eram rigidamente regulamentados pelo governo. 
Inicialmente, o sistema de aposentadoria japonês tinha por objetivo atender apenas aos militares e servidores públicos. Foram editados o decreto de aposentadoria dos marinheiros, em 1875, o de aposentadoria dos militares do exército, em 1876, e o de aposentadoria dos funcionários públicos, em 1884. Em 1890, foram unificados os decretos dos marinheiros e dos funcionários públicos. Mais tarde, todos esses textos legais foram compilados em um código de pensão, em 1923. As leis voltadas à população civil foram criadas somente depois, tendo sido editada em 1939 a lei de seguro dos marinheiros e, em 1941, a dos trabalhadores empregados (Lei ${ }^{\circ} 60$ de 1941).

b) Período imediatamente posterior à Segunda Guerra Mundial: recuperação

Na década de 40 e início dos anos 50, período de recuperação Pós-Guerra, o maior problema social do Japão era a pobreza. Durante a ocupação norte-americana, o Japão obteve conhecimentos sobre os princípios dos direitos sociais e o Plano Beveridge. A ideia em destaque era aquela de que a pobreza seria um problema resultante da própria estrutura econômica e, portanto, deveria ser resolvido por meio da geração de empregos pelas empresas privadas, e não pela concessão de medidas públicas de assistência social. Diante do esforço empreendido pelo governo japonês em promover o pleno emprego, naquele momento o modelo de bem-estar social era mais parecido com o escandinavo ou "social-democrático".

Em 1944, a lei de aposentadoria dos trabalhadores comuns de 1941 passou a ser chamada de "Lei do Seguro e Aposentadoria dos Trabalhadores Empregados". Esta lei foi amplamente reformada em 1954, tornando-se a "Lei da Previdência Social".

$\mathrm{Na}$ verdade, entre o final dos anos 50 até o começo dos anos 70, o período de crescimento econômico foi acompanhado pela ampliação da acessibilidade dos programas de proteção social à população, principalmente de aposentadoria e de saúde. A cobertura universal da aposentadoria, inclusive, foi alcançada em 1961, quando foi introduzido o plano de aposentadoria dos trabalhadores autônomos. Com isso, todo indivíduo passou a ter acesso a algum plano de aposentadoria, juntamente com o já existente plano de aposentadoria dos trabalhadores empregados. 
c) Período a partir da década de 70: desde o crescimento econômico até a época contemporânea

Todavia, estava enraizada a ideia tradicional de que a família seria a principal fonte de renda e deveria prover ajuda financeira aos parentes que não dispunham de meios próprios de subsistência. Esta era a base do modelo "residual-liberal", segundo o qual o Estado interferiria apenas quando a família não mais dispusesse de nenhuma capacidade de auxiliar o indivíduo.

Ainda que aparentemente o governo japonês não estivesse investindo o montante necessário para cobrir os gastos com os programas de seguridade social (ao menos tomando por base o PIB do país na época), o fato é que os benefícios oferecidos aos segurados japoneses eram significativos. E, conforme a população envelhecia, aumentavam cada vez mais os gastos com a seguridade social. Assim, apareciam mais e mais críticas de dentro e de fora do governo alertando para o chamado "problema do envelhecimento da sociedade" (koreika shakai mondai).

As mudanças começaram a despontar no início dos anos 70, quando as pessoas passaram a se preocupar mais com questões ligadas à qualidade de vida, uma vez que o nível de renda havia melhorado. Sob tais circunstâncias, o governo japonês passou a investir substancialmente nas políticas de proteção social, implantando a "Reforma de 1973", considerada o marco inaugural da seguridade social japonesa.

Na década de 80 foi implementada uma ampla e austera reforma administrativa com o objetivo principal de combater o excesso de burocracia (refletida na proliferação de agências governamentais, por exemplo), entre outros aspectos, além de reformar o próprio sistema de seguridade social. Nessa linha, tomaram-se medidas para diminuir o acesso à assistência gratuita à saúde para idosos, conter os gastos com a saúde pública e redistribuir os gastos sociais entre os governos nacional e local.

Em 1985 foi introduzida a chamada "Aposentadoria Básica” (Lei nº 34 de 1985), segundo a qual se aplicava um único sistema de aposentadoria para todos os cidadãos, independentemente das atividades profissionais. Logo mais, em 1989, foi criado o fundo de 
aposentadoria dos cidadãos japoneses, além de outras regras, como a da participação de estudantes (Lei no 86 de 1989).

Com a crise econômica a criar ainda mais empecilhos para os investimentos nessa área e diante da necessidade premente de atender à população idosa, formulou-se um projeto de longo prazo, o chamado "Plano Dourado" ou "Plano para a Promoção de Saúde e Bem-Estar à População Idosa em Dez Anos" (Koreisha Hoken Fukushi Suishin Jukanen Senryaku), vigente em 1990. Trata-se de uma estratégia ambiciosa cuja meta foi expandir os serviços prestados pelo governo e pela comunidade aos idosos, a exemplo de programas de assistência doméstica (prestados na própria residência do indivíduo). A demanda foi tanta que as metas precisaram ser ampliadas pelo “Novo Plano Dourado” de 1994 (Lei no 95 de 1994).

Em paralelo ao Plano Dourado, foi implementada a Assistência a Longo Prazo (Kaigo Hoken), outra medida voltada a ampliar o atendimento à população idosa crescente. De acordo com esse programa, o segurado recebe uma ajuda de custo para cobrir suas despesas médicas em estabelecimentos reconhecidos pelo governo, independentemente de sua renda ou da existência de um parente que possa lhe prover auxílio, muito diferente dos programas anteriores.

Posteriormente, ainda no contexto da necessidade de atendimento à crescente população idosa, a reforma de 2000 (Lei $\mathrm{n}^{\circ} 18$ de 2000) aumentou a idade estipulada para o início do recebimento do benefício, entre outras mudanças. A reforma de 2004 (Lei $n^{\circ} 104$ de 2004) trouxe inclusive alterações na forma de cálculo dos benefícios dos trabalhadores aposentados que continuavam na ativa.

Como visto, o modelo de seguridade social japonês passou por uma evolução que acompanhou sua realidade particular. Se no começo a posição da família era o destaque, constituindo a principal, senão única fonte de renda ou de auxílio do indivíduo carente de cuidados financeiros ou até mesmo médicos, pouco a pouco o Estado assumiu um papel mais ativo. 
3. A seguridade social do Japão

Como determina o próprio Artigo 25 da Constituição do Japão: “Todo o povo deve ter o direito de manter os padrões mínimos de vida sã e instruída. Em todas as esferas da vida, o Estado deve utilizar seus esforços para a promoção e extensão do bem-estar social e da seguridade, bem como da saúde pública", preconizando assim o dever do governo japonês de garantir a seguridade social de toda a sua população.

O sistema de seguridade social do Japão é composto basicamente pelo sistema de aposentadoria, pelo sistema de saúde e pelos serviços de bem-estar social, sendo que cada uma dessas categorias compreende diversos tipos de serviços direcionados à assistência de segmentos específicos da população. Vale citar, por exemplo, o Seguro Saúde para Idosos em Idade Avançada, aplicável somente a idosos com pelo menos 75 anos de idade, ao passo que indivíduos com menos de 75 anos de idade estarão sujeitos a outras categorias de seguro saúde.

Na prática, cada política de seguridade é gerida por uma de diversas agências do Ministério, sendo estas as principais relacionadas ${ }^{66}$ : Agência de Políticas de Saúde, Agência de Serviços de Saúde, Agência do Trabalho, Agência de Seguridade do Emprego (que engloba Departamentos de Promoção Exclusiva ao Emprego de Trabalhadores Desempregados, Trabalhadores Temporários, Trabalhadores Idosos e Trabalhadores com Deficiências), Agência de Proteção ao Emprego Igual, das Crianças e das Famílias, Agência do Bem-Estar Social e de Auxílio às Vítimas de Guerras (da qual faz parte o Departamento de Promoção da Saúde e Bem-Estar Social das Pessoas com Deficiências), Agência da Saúde e Bem-Estar Social dos Idosos, Agência do Seguro Saúde e Agência de Gestão das Aposentadorias, além de outras instituições afiliadas e conselhos regionais.

Na ocorrência de grandes desastres naturais, serviços especiais são designados para atender às necessidades surgidas, como o Plano de Assistência Médica de Longo Prazo aos trabalhadores que atuaram emergencialmente nos eventos relacionados com a explosão na Usina Nuclear

\footnotetext{
${ }^{66}$ Fonte: http://www.mhlw.go.jp/english/org/detail/dl/organigram.pdf
} 
TEPCO Fukushima Daiichi, causada pelo terremoto ocorrido no leste do Japão em 11 de Março de 2011 ${ }^{67}$.

Além dos serviços, os benefícios das categorias podem ser oferecidos também em forma de pecúnia, seguindo a classificação da OIT, conforme visto abaixo, com as formas de financiamento, benefícios e objetivos ${ }^{68}$ :

\begin{tabular}{|c|c|c|c|}
\hline $\begin{array}{l}\text { Principais tipos de } \\
\text { serviço }\end{array}$ & $\begin{array}{c}\text { Forma de } \\
\text { financiamento }\end{array}$ & Forma de benefício & $\begin{array}{l}\text { Objetivo/alvo de } \\
\text { proteção }\end{array}$ \\
\hline Aposentadoria Pública & Contribuição social & Pecúnia & $\begin{array}{c}\text { Idosos, sobreviventes, } \\
\text { inválidos }\end{array}$ \\
\hline Seguro Saúde & Contribuição social & Serviço & Saúde \\
\hline Saúde Pública & Impostos & Serviço & Saúde \\
\hline $\begin{array}{c}\text { Assistência de Longo } \\
\text { Prazo }\end{array}$ & Contribuição social & Serviço & Idosos \\
\hline $\begin{array}{l}\text { Assistência para } \\
\text { Idosos (exceto a de } \\
\text { Longo Prazo) }\end{array}$ & Impostos & Serviço & Idosos \\
\hline $\begin{array}{l}\text { Assistência para } \\
\text { famílias }\end{array}$ & Impostos & Pecúnia/Serviço & Famílias \\
\hline $\begin{array}{l}\text { Assistência para } \\
\text { pessoas com } \\
\text { deficiência }\end{array}$ & Impostos & Pecúnia/Serviço & $\begin{array}{c}\text { Pessoas com } \\
\text { deficiência }\end{array}$ \\
\hline Assistência pública & Impostos & Pecúnia/Serviço & $\begin{array}{c}\text { Pessoas } \\
\text { necessitadas/público } \\
\text { em geral }\end{array}$ \\
\hline Seguro Emprego & Contribuição social & Pecúnia & $\begin{array}{c}\text { Desempregados e } \\
\text { dependentes }\end{array}$ \\
\hline $\begin{array}{c}\text { Seguro Acidente de } \\
\text { Trabalho }\end{array}$ & Contribuição social & Pecúnia/Serviço & $\begin{array}{l}\text { Acidentados em } \\
\text { trabalho }\end{array}$ \\
\hline
\end{tabular}

\footnotetext{
${ }^{67}$ Fonte: http://www.mhlw.go.jp/english/topics/2011eq/workers.html

${ }^{68}$ Relatório de apresentação do IPSS publicado em janeiro de 2011, p. 7. Fonte: http://www.ipss.go.jp/prad/e/ipss_english2011.pdf (acesso em 14/07/2013).
} 
Passa-se em seguida a tratar separadamente de cada um dos principais programas de seguridade social.

\subsection{Aposentadoria}

A Aposentadoria Básica (基礎年金/ Kiso Nenkin) ${ }^{69}$ tem por objetivo prover a cobertura universal para toda a população japonesa. Não apenas os idosos são beneficiários das pensões, mas também os são aqueles indivíduos que não têm condições de trabalhar para se sustentar e/ou sustentar seus dependentes e, em último caso, também são beneficiários os dependentes sobreviventes do segurado falecido.

Desse modo, este trabalho contemplará destacadamente o Sistema de Aposentadoria Pública (公的年金制度), o qual compreende a Aposentadoria dos Empregados (被用者年金制度) e a Aposentadoria Nacional (国民年金制度)，garantidora da chamada Aposentadoria Básica. Todos os indivíduos não acobertados pela Aposentadoria dos Empregados deverão estar obrigatoriamente protegidos pela Aposentadoria Nacional.

A Aposentadoria dos Empregados compreende o Sistema de Seguro e Aposentadoria dos Trabalhadores Empregados ${ }^{70}$ (厚生年金保険制度), a Associação de Auxílio Mútuo aos Funcionários Públicos Federais (国家公務員共済組合), a Associação de Auxílio Mútuo aos Funcionários Públicos Regionais (地方公務員共済組合) e a Associação de Auxílio Mútuo aos Professores de Escolas Particulares (私立学校教職員共済) ${ }^{71}$.

Como regra, todos os residentes que tenham entre 20 e menos de 60 anos de idade devem contribuir à Aposentadoria Básica, inclusive aqueles que não possuem nacionalidade japonesa.

\footnotetext{
${ }^{69}$ Conforme exposto anteriormente, a Reforma de 1985 (por meio da edição da Lei no 34 de 1985) substituiu o sistema até então baseado nas categorias profissionais dos trabalhadores, estabelecendo a partir de então um sistema comum a todos o eles, denominado "básico".

${ }^{70} \mathrm{O}$ Acordo Previdenciário Brasil-Japão, referido mais adiante, utiliza o termo "Seguro de Pensão dos Empregados".

${ }^{71}$ O Acordo Previdenciário Brasil-Japão, referido mais adiante, utiliza o termo "Pensão Mútua" para essas categorias.
} 
Atualmente, a idade inicial do benefício é de 65 anos para o programa da Aposentadoria Nacional e 60 anos para a Aposentadoria dos Empregados (a ser aumentada para 65 anos de idade a partir de 2025, para homens e, a partir de 2030, para mulheres) ${ }^{72}$.

Sob a ótica do sistema de aposentadoria japonês, os segurados obrigatórios são classificados essencialmente em três categorias:

(I) Empregados e funcionários de empresas públicas e privadas: os empregados de empresas privadas devem se inscrever no Seguro e Aposentadoria dos Empregados (Kosei Nenkin), ao passo que os funcionários de empresas públicas e empregados de empresas de economia mista devem se inscrever nas Associações de Auxílio Mútuo.

(II) Dependentes de (I): trata-se das esposas, cujos rendimentos sejam inferiores à faixa mínima tributável, dependentes dos segurados acima referidos (empregados de empresas privadas e funcionários de empresas públicas).

(III) Indivíduos que não sejam considerados como pertencentes às categorias (I) e (II), referindo-se aqui aos trabalhadores não empregados (como microempresários, agricultores e trabalhadores autônomos em geral): estes são acobertados pela Aposentadoria Nacional (Kokumin Nenkin).

Passamos a analisar cada um dos dois principais programas de aposentadoria.

\subsubsection{Aposentadoria Nacional}

A Aposentadoria Nacional é o principal programa, tendo sido estabelecido em 1961. É operado pelo Serviço Japonês de Aposentadoria (JPS).

Como regra, os segurados obrigatórios são os residentes registrados no Japão que trabalhem sem vínculo empregatício, como os trabalhadores autônomos, microempresários e agricultores, além dos estudantes. Devem contribuir os indivíduos que possuam entre 20 e menos de 60

\footnotetext{
${ }^{72}$ The point of the pension plan, p. 30.
} 
anos de idade. Somente aqueles que contribuíram por pelo menos 25 anos podem ser beneficiados, sendo que o período contributivo alcançará, no máximo, 40 anos.

Além dessas categorias de segurados obrigatórios, é possível a inscrição voluntária ${ }^{73}$ na Aposentadoria Nacional dos:

(I) Trabalhadores autônomos que tenham entre 60 e menos de 65 anos de idade que desejem complementar o período de contribuição mínima e que não tenham conseguido alcançar o período máximo de contribuição que lhes permita usufruir os benefícios máximos;

(II) Indivíduos que possuam nacionalidade japonesa e idade entre 20 e 65 anos que residam no exterior;

(III) Indivíduos nascidos até $1^{\circ}$ de abril de 1965 e ao atingir entre 65 e 70 anos de idade, que desejem complementar o período de contribuição.

O valor da contribuição é fixo e mensal ${ }^{74}$.

Excepcionalmente, os indivíduos em situação de comprovada dificuldade financeira para arcar com as contribuições podem se beneficiar de isenção parcial ou total ${ }^{75}$, mediante aprovação do Serviço Japonês de Aposentadoria. Em momento posterior, é permitido o pagamento retroativo, compensando-se um período isento de até 10 anos e computando-o para fins do cálculo da pensão a ser recebida ${ }^{76}$.

Outra exceção prevista é a possibilidade de estudantes e/ou indivíduos com idade abaixo de 30 anos que possuam renda baixa solicitarem ao Serviço de Aposentadoria a postergação do termo inicial de contribuição.

\footnotetext{
${ }^{73}$ Fonte: http://www.nenkin.go.jp/n/www/english/detail.jsp?id=38 (acesso em 16/11/2013).

${ }^{74} \mathrm{O}$ valor vigente entre Abril 2013 e Março 2014 era de $¥ 15.040,00$ / mês. O valor é reajustado todo ano em $¥ 280,00$, chegando ao teto de $¥ 16.900,00$ no ano fiscal de 2017. Fonte: The point of the pension plan, p. 16.

${ }^{75} \mathrm{As}$ isenções podem variar entre $25 \%$ a $100 \%$. Fonte: http://www.nenkin.go.jp/n/open_imgs/free3/0000000011_0000011269.pdf

${ }^{76}$ Fonte: http://www.nenkin.go.jp/n/open_imgs/free3/0000000011_0000011269.pdf O cálculo da pensão será melhor detalhado mais adiante.
} 
No que se refere aos benefícios da Aposentadoria Básica por Idade, são qualificados para recebê-los os segurados que tenham completado 65 anos de idade e um período contributivo total de pelo menos 25 anos (incluídos os períodos de isenção).

Os beneficiários da Aposentadoria Básica por Idade que tenham contribuído pelo período máximo de 40 anos recebem o equivalente a $¥ 786.500,00 /$ ano $^{77}$. Embora em princípio o início de recebimento do benefício seja a partir dos 65 anos de idade, também é permitido que se adiante o termo de início do recebimento para o período entre 60 e 65 anos de idade, quando a pensão sofreria uma redução proporcional ao período de adiantamento, ou mesmo a postergação do início do termo de recebimento, quando a pensão sofreria um aumento proporcional $^{78}$.

A legislação japonesa prevê também a Aposentadoria Básica por Invalidez, aplicável àqueles indivíduos com alguma deficiência ou doença que os incapacite para atividades laborais, desde que a invalidez tenha alcançado um determinado grau (conforme exigência em lei) e que no ato do exame médico que tenha diagnosticado a doença ou deficiência o indivíduo seja segurado da Aposentadoria Nacional. As pensões são de ¥983.100,00 / ano para os inválidos de grau 1 e de $¥ 786.500,00$ para os inválidos de grau $2^{79}$.

\footnotetext{
${ }^{77} \mathrm{O}$ cálculo do benefício considera as eventuais isenções concedidas, diminuindo proporcionalmente o valor da pensão a ser recebida. A fórmula geral para cálculo, em ienes, da pensão anual da Aposentadoria por Idade consiste em 786.500,00 x (A + B + C + D + E) / 40 x 12, onde:

A: número de meses de contribuição efetiva (sem isenção)

B: número de meses sem contribuição efetiva (com 100\% de isenção), multiplicado por $1 / 3$

C: número de meses de contribuição com $75 \%$ de isenção, multiplicado por $1 / 2$

D: número de meses de contribuição com $50 \%$ de isenção, multiplicado por $2 / 3$

E: número de meses de contribuição com $25 \%$ de isenção, multiplicado por $5 / 6$.

Note-se que a fórmula pode variar conforme a data do nascimento do indivíduo e os meses e anos em que foram pagas as contribuições ou concedidas as isenções.

${ }^{78}$ Em caso de adiantamento do termo inicial de recebimento de pensão para os 60 anos de idade, o valor que seria recebido aos 65 anos de idade seria reduzido para 70\%. Caso se postergue o termo de início de recebimento para 70 anos de idade, a pensão poderá ser aumentada para 142\% do valor normal. Fonte: http://www.nenkin.go.jp/n/www/english/detail.jsp?id=38 (As informações aqui reportadas foram fornecidas pelo Serviço Japonês de Aposentadoria (JPS) e foram atualizadas até 09/10/2013. Outros detalhes relativos aos cálculos de proporcionalidade dos benefícios podem ser encontrados em The point of the pension plan, p. 20).

${ }^{79} \mathrm{O}$ grau 1 identifica os indivíduos incapazes de realizar sequer as tarefas diárias básicas sem auxílio de outras pessoas, e o grau 2 identifica os indivíduos eventualmente capazes de tomar conta de si mesmos, mas ainda assim incapacitados para exercer atividades laborais (Cf. The point of the pension plan, p. 23).
} 
Caso o segurado venha a falecer enquanto contribuinte da Aposentadoria Nacional, sua esposa dependente que tome conta de filho/filha(s), ou seu/sua(s) filho/filha(s) sobrevivente(s) terá/terão direito ao recebimento da pensão, até que o/a filho/filha complete 18 anos de idade (ou 20 anos de idade, em caso de deficiência comprovada e prevista em lei). Para a viúva com um (a) filho/filha a pensão a ser paga é de $¥ 1.012 .000,00 /$ ano $^{80}$.

Ademais, também está prevista em lei a pensão por viuvez paga à viúva sobrevivente de marido segurado que tenha contribuído por pelo menos 25 anos, enquanto ela possuir mais de 60 anos mas não houver completado ainda 65 anos de idade ${ }^{81}$.

Se o segurado vier a falecer antes de receber qualquer parte da pensão, seja oriunda da Aposentadoria por Idade, seja por Invalidez, os familiares que residiam com ele poderão efetuar a retirada total dos valores pagos pelo segurado (saque único) ${ }^{82}$.

Por fim, também é permitido aos indivíduos estrangeiros que tenham residido no Japão e contribuído para a Aposentadoria Nacional por pelo menos seis meses a retirada total dos valores pagos, dentro de dois anos de sua saída do território japonês. Todavia, tendo contribuído por 36 meses ou mais, o valor a ser devolvido será fixo ${ }^{83}$.

\subsubsection{Aposentadoria dos Empregados}

A Aposentadoria dos Empregados (Kosei Nenkin Hoken) diz respeito ao Seguro e Aposentadoria dos Trabalhadores Empregados e às Associações de Auxílio Mútuo, dos quais devem participar, respectivamente, os empregados de empresas privadas e os funcionários públicos.

Os segurados obrigatórios são os indivíduos com idade abaixo de 70 anos que trabalhem como empregados de empresas privadas que empregam pelo menos cinco trabalhadores, os

\footnotetext{
${ }^{80} \mathrm{Um}$ valor adicional é pago de acordo com o número de menores de idade dependentes. Fontes: http://www.nenkin.go.jp/n/open_imgs/free3/0000000011_0000011269.pdf e The point of the pension plan, p. 24.

${ }^{81}$ Fonte: The point of the pension plan, p. 25.

${ }^{82}$ Fonte: http://www.nenkin.go.jp/n/www/english/detail.jsp?id=38

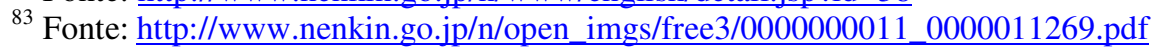


funcionários públicos, além dos cônjuges dependentes (de trabalhadores de ambas as categorias) que possuam entre 20 e 60 anos de idade ${ }^{84}$. Também são segurados os trabalhadores em tempo parcial cuja jornada de trabalho seja equivalente a $75 \%$ da jornada do trabalhador em período integral ${ }^{85}$.

Os empregadores têm a obrigação de inscrever seus empregados no programa ${ }^{86}$.

Especialmente, as esposas dependentes dos empregados são isentas de contribuir individualmente para o programa de aposentadoria, sendo o esposo segurado responsável pela contribuição do casal. Posteriormente, quando a esposa se aposentar, os custos de sua aposentadoria serão cobertos pelo programa para o qual o esposo contribuiu (seja o Seguro e Aposentadoria dos Trabalhadores Empregados ou uma das Associações de Auxílio Mútuo) ${ }^{87}$.

É possível se inscrever voluntariamente no programa em determinadas situações, por exemplo, quando o empregado atinge 70 anos de idade, mas ainda não havia contribuído por tempo suficiente para se qualificar para a Aposentadoria Básica por Idade ${ }^{88}$.

As contribuições são baseadas na renda mensal do segurado. O percentual aplicado sobre a renda mensal ${ }^{89}$ dos empregados de empresas privadas é de $17,120 \%{ }^{90}$, sendo metade $(8,56 \%)$ suportada pelo empregador, que deve reter sobre o salário mensal a parte do empregado e recolher em nome deste o valor integral. O mesmo procedimento de rateio de encargo é aplicado aos funcionários públicos, cuja renda mensal se submete a um percentual de contribuição que varia entre 12,230\% e 15,154\%, dependendo da Associação de Auxílio Mútuo.

\footnotetext{
${ }^{84}$ Fonte: http://www.mhlw.go.jp/english/org/policy/dl/p36-37p2.pdf (p. 3).

${ }^{85}$ Fonte: Investing in Japan, item 4.9.5.

${ }^{86}$ Fonte: http://www.nenkin.go.jp/n/www/english/detail.jsp?id=39

${ }^{87}$ Fonte: The point of the pension plan, p. 15.

${ }^{88}$ Fonte: http://www.nenkin.go.jp/n/www/english/detail.jsp?id=39

${ }^{89}$ Para a base de cálculo aplicam-se os limites de $¥ 620.000,00$ para o salário mensal e de $¥ 1.500 .000,00$ para o bônus regular mensal. Fonte: The point of the pension plan, p. 19.

${ }^{90}$ Fonte: Investing in Japan, item 4.9.5. Todo mês de setembro o percentual é reajustado em $0.354 \%$ até o teto de 18,3\% em 2017. Fonte: The point of the pension plan, p. 15.
} 
Os requisitos básicos para se qualificar à Aposentadoria dos Empregados por Idade são os mesmos da Aposentadoria Básica por Idade, isto é, são qualificados para receber os benefícios os segurados que tenham completado 65 anos de idade e um período contributivo total de pelo menos 25 anos.

Note-se que, em face das reformas legislativas ocorridas em 1994 e 2000, a idade inicial da Aposentadoria dos Empregados por Idade pode variar conforme o ano de aposentadoria e a data de nascimento do segurado.

Entre os anos de 2000 e 2025 os segurados podem optar, além da Aposentadoria dos Empregados por Idade, também pela Aposentadoria Especial dos Empregados, sendo que esta última será extinta definitivamente no ano fiscal de 2025, passando nesse meio tempo por um período de transição, que consiste no aumento gradativo da idade mínima de aposentadoria de 60 para 65 anos de idade. Interessante notar que este aumento gradativo é efetuado em duas fases: primeiro para o recebimento da parte fixa da pensão e posteriormente para a parte variável $^{91}$.

Assim sendo, de acordo com a Reforma de 1994, os indivíduos aposentados em 2000 (desde que nascidos antes de $1^{\circ}$ de abril de 1941) e que tivessem na época entre 60 e 65 anos de idade puderam se beneficiar tanto do recebimento da parte fixa quanto da parte variável da pensão (calculada com base na renda), conferidas pela Aposentadoria Especial dos Empregados. Já aqueles que se aposentaram aos 65 anos de idade se beneficiaram da Aposentadoria dos Empregados por Idade.

Nos anos seguintes ainda foi possível se beneficiar da Aposentadoria Especial dos Empregados para recebimento da pensão de valor fixo, mas a idade mínima de aposentadoria de 60 anos foi aumentada consecutivamente todo ano ${ }^{92}$ até chegar aos 65 anos de idade em 2013, quando a pensão de valor fixo deixou de existir, restando a Aposentadoria Especial dos

\footnotetext{
${ }^{91}$ Fonte: The point of the pension plan, p. 21.

${ }^{92}$ A idade inicial da Aposentadoria Especial por Idade era diferente para homens e mulheres, em razão do aumento da idade inicial para homens ter começado dois anos antes do aumento aplicável às mulheres, como determinado pela lei. Em 2011, por exemplo, a idade inicial para homens era de 64 anos e para mulheres era de 62 anos.
} 
Empregados para recebimento de pensão de valor variável (ainda com a idade mínima de 60 anos), além da própria Aposentadoria dos Empregados por Idade e da Aposentadoria Básica por Idade (aos 65 anos de idade).

Por seu turno, a Reforma de 2000 determinou a extinção também da possibilidade de recebimento de pensão variável pela Aposentadoria Especial dos Empregados, através do aumento consecutivo anual da idade mínima de aposentadoria até o ano de 2025, quando restará apenas a opção de se aposentar aos 65 anos de idade pela Aposentadoria dos Empregados por Idade ou pela Aposentadoria Básica por Idade ${ }^{93}$.

Logo, em 2025 terá sido completada a equalização das regras da Aposentadoria dos Empregados para todos os segurados da categoria, existindo apenas um programa em vigência, a Aposentadoria dos Empregados por Idade.

Em termos de benefícios, há um cálculo próprio para as pensões a serem recebidas em cada um dos dois programas.

Com relação à Aposentadoria Especial dos Empregados, chega-se ao valor da pensão somando-se uma parte fixa e uma parte variável, além de um adicional, se aplicável. A parte variável é calculada com base na média da renda do segurado no período contributivo ${ }^{94}$.

\footnotetext{
${ }^{93}$ Fonte: The point of the pension plan, p. 21.

${ }^{94}$ Para o cálculo da Aposentadoria Especial dos Empregados aplica-se a fórmula $[\mathbf{A}]+[\mathbf{B}]+[\mathbf{C}]$, onde:

Parte Fixa: $[\mathrm{A}]=\mathbf{a} \times \mathbf{b} \times \mathbf{0 , 9 7 8}$

a: valor de $¥ 1.626,00$ a $¥ 3.143,00$, dependendo da data de nascimento do segurado

b: número de meses de cobertura (limitado a 480 meses)
}

Parte Variável: $[\mathrm{B}]=(\mathrm{c}+\mathrm{d}) \times \mathbf{1 , 0 3 1} \times \mathbf{0 , 9 7 8}$

c: [renda média mensal do segurado até março de 2003, atualizadas até o presente] x [valor entre 10/1000 e 7,5/1000, dependendo da data de nascimento do segurado] x [número de meses de cobertura até março de 2003] d: [renda média mensal do segurado mais bônus a partir de abril de 2003, atualizadas até o presente e divididas pelo número de meses de cobertura, inclusive abril de 2003 e posteriores] x [valor entre 7,692/1000 e 5,769/1000, dependendo da data de nascimento do segurado] x [número de meses de cobertura a partir de abril de 2003]

\section{Parte Adicional Anual: [C]}

Os segurados que contribuíram para a Aposentadoria dos Empregados por 20 anos ou por 15 anos após completar 40 anos de idade ( 35 anos no caso das mulheres), e que possuam familiares dependentes na época em que o indivíduo atingir a idade mínima necessária, farão jus à parte adicional anual. Para tanto, são considerados dependentes os cônjuges com idade abaixo de 65 anos e filhos que não tenham atingido 18 anos de idade em 31 
Por sua vez, o cálculo da pensão da Aposentadoria dos Empregados por Idade considera as mesmas bases das partes variável e adicional da Aposentadoria Especial dos Empregados, além da eventual diferença existente entre o valor fixo que seria recebido de acordo com a Aposentadoria dos Empregados por Idade e o valor da Aposentadoria Básica por Idade ${ }^{95}$.

Aos segurados que prossigam trabalhando mesmo após atingir a idade mínima de aposentadoria aplica-se uma regra de redução proporcional ou de suspensão total do pagamento da pensão. Aos segurados que possuam entre 60 e 64 anos de idade, o valor cheio do benefício será pago até que a renda mensal do indivíduo (salário mais bônus) alcance $¥ 280.000,00$, após o qual o valor será reduzido ou suspenso em sua totalidade. Aos segurados

de março (ou 20 anos de idade, caso possua deficiência prevista em lei). Os valores dos benefícios são de $¥ 226.300,00$ para o cônjuge, $¥ 226.300,00$ para o (a) primeiro (a) e segundo (a) filhos (as), além de $¥ 75.400,00$ para cada um dos outros filhos, se houver.

Fonte: The point of the pension plan, p. 20 e http://www.nenkin.go.jp/n/www/english/detail.jsp?id=39 (os dados foram atualizados até 19/03/2013).

${ }^{95}$ Para o cálculo da Aposentadoria dos Empregados por Idade aplica-se a fórmula [D]+[E]+[F], onde:

Parte Transicional: $[\mathrm{D}]=[\mathrm{A}]-\mathbf{m}$

Parte Fixa: $[\mathbf{A}]=\mathrm{a} \times \mathrm{b} \times 0,978$

a: valor de $¥ 1.626,00$ a $¥ 3.143,00$, dependendo da data de nascimento do segurado

b: número de meses de cobertura (limitado a 480 meses)

m: $786.500,00 \times(\mathrm{A}+\mathrm{B}+\mathrm{C}+\mathrm{D}+\mathrm{E}) / 40 \times 12$, onde:

A: número de meses de contribuição efetiva (sem isenção)

B: número de meses sem contribuição efetiva (com $100 \%$ de isenção), multiplicado por $1 / 3$

C: número de meses de contribuição com $75 \%$ de isenção, multiplicado por $1 \frac{1}{2}$

D: número de meses de contribuição com $50 \%$ de isenção, multiplicado por $2 / 3$

E: número de meses de contribuição com $25 \%$ de isenção, multiplicado por $5 / 6$.

Parte Variável: $[\mathrm{E}]=(\mathrm{c}+\mathrm{d}) \times \mathbf{1 , 0 3 1}$ x 0,978

c: [renda média mensal do segurado até março de 2003, atualizadas até o presente] x [valor entre 10/1000 e 7,5/1000, dependendo da data de nascimento do segurado] x [número de meses de cobertura até março de 2003]

d: [renda média mensal do segurado mais bônus a partir de abril de 2003, atualizadas até o presente e divididas pelo número de meses de cobertura, inclusive abril de 2003 e posteriores] x [valor entre 7,692/1000 e 5,769/1000, dependendo da data de nascimento do segurado] x [número de meses de cobertura a partir de abril de 2003]

\section{Parte Adicional Anual: [F]}

Os segurados que contribuíram para a Aposentadoria dos Empregados por 20 anos ou por 15 anos após completar 40 anos de idade (35 anos no caso das mulheres), e que possuam familiares dependentes na época em que o indivíduo atingir a idade mínima necessária, farão jus à parte adicional anual. Para tanto, são considerados dependentes os cônjuges com idade abaixo de 65 anos e filhos que não tenham atingido 18 anos de idade em 31 de março (ou 20 anos de idade, caso possua deficiência prevista em lei). Os valores dos benefícios são de $¥ 226.300,00$ para o cônjuge, $¥ 226.300,00$ para o (a) primeiro (a) e segundo (a) filhos (as), além de $¥ 75.400,00$ para cada um dos outros filhos, se houver.

Fonte: The point of the pension plan, p. 20 e http://www.nenkin.go.jp/n/www/english/detail.jsp?id=39 (os dados foram atualizados até 19/03/2013). 
que completarem 65 anos de idade, aplicar-se-á à regra em questão o limite de renda mensal (salário mais bônus) de $¥ 460.000,00^{96}$.

A lei também prevê a Aposentadoria dos Empregados por Invalidez, quando os empregados segurados inválidos poderão receber uma pensão mensal ou uma indenização (valor de única retirada). Os requisitos são os mesmos da Aposentadoria Básica por Invalidez, isto é, a invalidez precisará ter alcançado certo grau previsto em lei e o indivíduo precisa ser um segurado no ato do exame médico que tenha diagnosticado a doença ou deficiência. Os benefícios observam um cálculo específico para cada um dos graus de invalidez ${ }^{97}$.

\footnotetext{
${ }^{96}$ Fonte: http://www.nenkin.go.jp/n/www/english/detail.jsp?id=39

${ }^{97}$ A invalidez dos segurados trabalhadores é classificada, segundo a legislação japonesa, desde o grau 1 até o 3. O grau 3 de invalidez, aplicável somente à Aposentadoria por Invalidez dos Empregados (não à Aposentadoria Básica por Invalidez) designa os trabalhadores cuja habilidade laboral tenha sido seriamente comprometida pela doença ou deficiência. Como já visto anteriormente neste trabalho, o grau 1 designa os indivíduos que necessitam de ajuda até mesmo para realizar suas atividades básicas diárias e o grau 2 designa os indivíduos que eventualmente podem precisar de ajuda para as atividades básicas diárias, mas que de toda forma não têm condições de trabalhar. Caso o indivíduo possua doença ou deficiência classificada como grau 1 ou 2 , será qualificado para receber tanto a pensão básica por invalidez (Aposentadoria Básica por Invalidez) quanto a pensão dos empregados por invalidez (Aposentadoria dos Empregados por Invalidez). Caso seja portador do grau 3 de invalidez, poderá receber apenas a pensão dos empregados por invalidez. Além da pensão, o segurado trabalhador poderá receber também a indenização por invalidez caso a classificação de sua condição seja abaixo do grau 3. A seguir são apresentadas as fórmulas de cálculo dos benefícios:
}

\section{Pensão por invalidez:}

Grau 1 de Invalidez: $(a+b) \times 1,031 \times 0,978 \times 1,25+c+d$

Grau 2 de Invalidez: $(a+b)$ x 1,031 x $0,978+c+d$

Grau 3 de Invalidez: $(a+b)$ x 1,031 x 0,978 (sendo o benefício mínimo de $¥ 589.900,00$ )

Onde:

a: [renda média mensal do segurado até março de 2003, atualizada até o presente] x [7,5/1.000] x [número de meses de cobertura até março de 2003]

b: [renda média mensal do segurado mais bônus a partir de abril de 2003, atualizadas até o presente e divididas pelo número de meses de cobertura, inclusive abril de 2003 e posteriores] x [7,5/1.000] x [número de meses de cobertura a partir de abril de 2003]

c: parte adicional anual no valor de $¥ 226.300,00$, concedida quando o cônjuge dependente do segurado possuir menos de 65 anos de idade.

d: pensão pela Aposentadoria Básica por Invalidez (já visto nesse trabalho anteriormente)

Indenização por invalidez:

(e+f) $x$ 2, limitado a $¥ 1.150 .200,00$, onde:

e: [renda média mensal do segurado até março de 2003, atualizada até o presente] x [7,125/1.000] x [número de meses de cobertura até março de 2003]

f: [renda média mensal do segurado mais bônus a partir de abril de 2003, atualizadas até o presente e divididas pelo número de meses de cobertura, inclusive abril de 2003 e posteriores] x [5,481/1.000] x [número de meses de cobertura a partir de abril de 2003]

Nota: caso o número total de meses de cobertura em e e f seja inferior a 300 (equivalente a 25 anos), será então considerado para o cálculo 300 meses. 
A legislação prevê ainda o pagamento de pensão aos dependentes do/da trabalhador (a) falecido/falecida, desde que na época do falecimento ele/ela tenha atendido as condições de segurado/segurada da Aposentadoria dos Empregados por Idade ou por Invalidez (grau 1 ou 2) e o(s) beneficiário(s) devem ser financeiramente dependente(s) dele/dela. A viúva que cuidar do(s)/da(s)s filho(s)/filha(s) sobrevivente(s) que tenha(m) menos de 18 anos de idade (ou 20 anos de idade se possuir de deficiência prevista em lei) poderá receber a pensão do sobrevivente pela Aposentadoria dos Empregados, além da pensão básica do sobrevivente (pela Aposentadoria Nacional) ${ }^{98}$.

Está prevista ainda a possibilidade dos indivíduos estrangeiros que tenham trabalhado no Japão e contribuído para a Aposentadoria dos Empregados por pelo menos 6 meses a retirada total dos valores pagos, dentro de um período de dois anos após deixar o território japonês. Note-se que, caso o indivíduo houver contribuído por um período maior que 36 meses, o cálculo do valor a ser devolvido será baseado no limite de 36 meses ${ }^{99}$.

Mais adiante neste trabalho será abordada a possível dispensa de participação de empregados estrangeiros no sistema de aposentadoria japonês, mediante vigência de acordo internacional de previdência social assinado entre o Japão e o país de origem do trabalhador.

Finalmente, observe-se que os indivíduos residentes no Japão que possuam entre 20 e menos de 60 anos de idade porventura inelegíveis para a Aposentadoria dos Empregados devem obrigatoriamente participar da Aposentadoria Nacional, submetendo-se às regras tratadas no tópico anterior desse trabalho ${ }^{100}$.

Fonte: http://www.nenkin.go.jp/n/www/english/detail.jsp?id=39

${ }^{98} \mathrm{O}$ valor a ser pago ao dependente sobrevivente equivale a $3 / 4$ da parte variável da pensão a ser recebida de acordo com a Aposentadoria dos Empregados por Idade. Fonte: http://www.nenkin.go.jp/n/www/english/detail.jsp?id=39

${ }_{99}^{99}$ Fontes: The point of the pension plan, p. 26 e http://www.nenkin.go.jp/n/www/english/detail.jsp?id=39

${ }^{100}$ Cf.Investing in Japan, item 4.9.5. 


\subsubsection{Fundos de pensão ${ }^{101}$}

É válido mencionar também a existência de uma miríade de fundos de pensão em funcionamento na atualidade. A adesão a tais fundos é opcional e seu objetivo é complementar a renda pós-aposentadoria.

Resumidamente, existem os fundos de pensão de benefício definido (onde o valor de benefício é estipulado já no ato da adesão, definindo o período contributivo) e aqueles de contribuição definida (onde o valor do benefício será determinado com base no retorno do investimento) ${ }^{102}$. Os inúmeros fundos de pensão corporativos, voltados aos empregados participantes, são geridos por uma empresa ou um grupo de empresas, sob o formato de fundos de investimentos (investindo em ativos).

Existem também os fundos de pensão nacional, que podem ser regionais ou setoriais (por categoria profissional). São direcionados aos segurados pela Aposentadoria Nacional (trabalhadores autônomos em geral).

\subsection{Saúde}

O Sistema de Saúde do Japão ${ }^{103}$ oferece uma cobertura universal, permitindo que toda a população japonesa usufrua serviços de proteção à saúde, por conta das características a seguir apresentadas. Inclusive indivíduos residentes de longo prazo e de outras nacionalidades são solicitados a se inscrever no sistema ${ }^{104}$.

Estão previstos pelo sistema de saúde o fornecimento de serviços hospitalares e ambulatoriais, incluindo aqueles direcionados aos cuidados da saúde mental, além de serviços odontológicos e remédios sob prescrição médica. Desde 2000, a assistência à saúde de longo prazo passou a

\footnotetext{
${ }^{101}$ Trata-se de uma categoria à parte da Aposentadoria Pública Japonesa e por tal razão não enfocada neste trabalho.

${ }^{102}$ Fonte: The point of the pension plan, p. 36.

103 Infográfico contendo as linhas gerais da operacionalização do Sistema de Saúde em http://www.mhlw.go.jp/english/wp/wp-hw6/d1/02e.pdf (atualizado até junho/2012). V. também http://www.mhlw.go.jp/bunya/iryouhoken/iryouhoken01/dl/01_eng.pdf

${ }^{104}$ Observe-se que não há cobertura em matéria de saúde para imigrantes ilegais (cf. Ryozo Matsuda, p.66).
} 
integrar o Sistema de Assistência Social e ser administrado à parte por governos municipais, prevendo não apenas medidas remediadoras, mas também preventivas voltadas a indivíduos com idade a partir dos 40 anos de idade ${ }^{105}$.

No Sistema de Saúde, os segurados japoneses estão divididos basicamente em dois grupos: aqueles com menos de 75 anos de idade e aqueles com 75 anos de idade ou mais.

Os trabalhadores empregados com menos de 75 anos de idade (e seus dependentes) devem se inscrever no Seguro Saúde Corporativo, gerido por seus empregadores (sociedades empresariais de grande porte), ou pela Associação do Seguro Saúde do Japão (no caso de empresas de médio ou pequeno porte). Algumas categorias profissionais exigem a inscrição em planos geridos por associações especiais (por exemplo, professores da rede privada de ensino e marinheiros). O restante dos indivíduos com menos de 75 anos de idade (como desempregados, trabalhadores autônomos e outros) deve se inscrever no Seguro Saúde Nacional, gerido pelos governos municipais.

Já os indivíduos com 75 anos de idade ou mais devem se inscrever no Sistema de Saúde para Idade Avançada (Koki Koureisha Iryo Seido).

Por fim, as famílias pobres assistidas pela Assistência Social estão dispensadas de contribuir para o Sistema de Saúde. Inclusive, no que se refere à Assistência Social, está prevista uma categoria de benefícios voltada à assistência médica, mas o perfil dos assistidos é diferente ${ }^{106}$.

O financiamento se dá em parte pelo governo, em forma de subsídios, e em parte pelos próprios segurados, por meio de contribuições e coparticipação, sendo gerido por órgãos do Ministério da Saúde do Japão, mas com colaboração de entidades civis, como por exemplo, o Conselho Japonês para a Qualidade do Tratamento de Saúde (embora não exerça nenhum poder regulatório, este órgão tem por objetivo fiscalizar a adoção das diretrizes do sistema).

\footnotetext{
${ }^{105}$ Vide item 3.3.1 deste Capítulo, "Assistência de Longo Prazo".

${ }^{106}$ Vide item 3.3 deste Capítulo, mais abaixo.
} 
Como regra, a coparticipação nos serviços e outros bens fornecidos determina o pagamento de $30 \%$ dos preços, com exceção de crianças abaixo da idade escolar (coparticipação de 20\%) e idosos com pelo menos 70 anos de idade e de baixa renda (coparticipação de $10 \%{ }^{107}$ ). Os idosos que possuam entre 70 e 74 anos e renda considerada elevada coparticipam com 30\% também. Em situações emergenciais, como catástrofes naturais, está prevista uma coparticipação extra de $1 \%$. Há também subsídios específicos para segurados com deficiências físicas e/ou mentais, ou ainda de doenças crônicas.

A seguir, serão descritos mais detalhadamente cada um dos principais tipos de seguro saúde.

\subsubsection{Seguro Saúde dos Empregados}

O Seguro Saúde dos Empregados trata na verdade de dois tipos diferentes de seguro saúde, como relatado anteriormente: aquele gerido pelas sociedades empresariais de grande porte ou o chamado Corporativo, e outro gerido pela Associação do Seguro Saúde do Japão ${ }^{108}$ (em nome de empresas de médio ou pequeno porte).

Estão obrigados a participar deste sistema ${ }^{109}$, juntamente com seus dependentes ${ }^{110}$, todos os trabalhadores empregados que trabalham em empresas que empregam pelo menos cinco trabalhadores, além daqueles que, mesmo trabalhando em contrato de regime parcial, tenham sido contratados em condições equiparadas àquelas de trabalhadores de regime integral.

O sistema corporativo é operado por seguradoras organizadas pelas próprias corporações empregadoras, enquanto a Associação do Seguro Saúde opera um seguro coletivo para os empregados das empresas médias ou pequenas.

\footnotetext{
${ }^{107}$ A coparticipação é de 20\%, mas ficou limitada a 10\% em razão de uma medida orçamentária (IPSS, p. 28).

${ }^{108}$ Acesso a mais informações sobre a Associação do Seguro Saúde do Japão: http://www.kyoukaikenpo.or.jp/

${ }^{109}$ Fonte: Serviço de Aposentadoria Japonês.

${ }^{110}$ Estão acobertados pelo sistema os dependentes cujo principal provedor seja o segurado e que sejam parentes deste até o terceiro grau, segundo o Serviço de Aposentadoria Japonês (fonte: http://www.nenkin.go.jp/n/www/english/detail.jsp?id=1).
} 
No que se refere ao financiamento do Sistema de Seguro Saúde gerido por empresas de grande porte, é descontado um percentual fixo de contribuição do salário dos empregados, sendo outro igual recolhido pela empresa em benefício daquele empregado. Os percentuais variam entre $3 \%$ e 12\%. A Associação do Seguro Saúde do Japão aplica percentuais em torno de 10\%.

Finalmente, como citado anteriormente, algumas categorias profissionais possuem seus próprios sistemas de seguro, como os marinheiros e trabalhadores diaristas ${ }^{111}$. Outras possuem suas próprias associações de assistência mútua que gerenciam seus próprios sistemas: funcionários públicos nacionais, funcionários públicos locais e professores e trabalhadores da rede privada de ensino.

\subsubsection{Seguro Saúde Nacional}

O Seguro Saúde Nacional permite que todos os indivíduos não acobertados pelo Seguro Saúde dos Empregados, por exemplo, trabalhadores autônomos, agricultores, desempregados e pensionistas, além daqueles que tenham idade abaixo de 75 anos, tenham acesso ao sistema de saúde (algumas categorias profissionais, como a dos médicos, constituem sua própria associação seguradora).

Após a aposentadoria, os idosos antes segurados pelo Seguro Saúde dos Empregados passam a ser segurados pelo Seguro Saúde Nacional. Entretanto, até os 65 anos de idade, os serviços de saúde por eles solicitados são custeados pelo Seguro Saúde dos Empregados.

Este sistema é em parte subsidiado pelo governo municipal e financiado por meio do recolhimento de percentuais diferenciados de contribuição dos segurados, calculados com base nos rendimentos, propriedades e composição familiar destes.

\footnotetext{
${ }^{111}$ Aqui, referindo-se a trabalhadores que recebem salário calculado por dia.
} 


\subsubsection{Seguro Saúde para Idade Avançada}

Este sistema foi criado em 1983, originalmente destinado a distribuir equitativamente os custos dos cuidados médicos de idosos com pelo menos 70 anos de idade ou com idade entre 65 e 69 anos que estivessem acamados. Até então 30\% dos custos era financiado pelos governos local e nacional em forma de subsídios, sendo que os outros $70 \%$ provinham de contribuições alocadas do Seguro Saúde Nacional, do Seguro Saúde dos Empregados e da coparticipação dos idosos.

Porém, com o passar dos anos, o aumento da população idosa acabou por sobrecarregar o Seguro Saúde Nacional. Isso porque, na medida em que se aposentavam, estes indivíduos eram transferidos do Seguro Saúde dos Empregados para o Seguro Saúde Nacional. O desequilíbrio orçamentário se acumulava e exigia uma reforma.

A reforma demandada aconteceu em 2008, quando então passou a se exigir dos idosos com idade a partir de 75 anos uma contribuição e também uma coparticipação de 10\%, sendo 50\% dos custos subsidiados pelo governo e mantendo-se $40 \%$ financiado pela alocação de contribuições dos outros sistemas de saúde (o processo demandou a implantação de um sistema de equalização fiscal para os indivíduos que possuíam entre 65 e 74 anos de idade, acobertados pelo sistema substituído). A coparticipação pode subir para $30 \%$ se o segurado possuir renda familiar considerada elevada.

\subsection{Assistência Social}

O Sistema de Assistência Pública tem por objetivo garantir o padrão mínimo de vida e promover a autossubsistência dos cidadãos que vivem em estado de pobreza ${ }^{112}$, nos conformes do Artigo 25 da Constituição do Japão ${ }^{113}$. Por padrão mínimo de vida se entende a capacidade de manter uma vida sã e instruída ${ }^{114}$.

\footnotetext{
${ }^{112}$ Artigo $1^{\text {o }}$ da Lei de Assistência Pública do Japão.

${ }^{113}$ A Constituição do Japão e a Lei de Assistência Pública do Japão podem ser encontradas nos Anexos deste trabalho.

${ }^{114}$ Artigo $3^{\circ}$ da Lei de Assistência Pública do Japão.
} 
Todos os cidadãos japoneses, indiscriminadamente, têm direitos iguais de receber a assistência pública, desde que preenchidos todos os requisitos em lei ${ }^{115}$.

A assistência é concedida aos indivíduos que, mesmo depois de computada toda e qualquer fonte de renda ou auxílio financeiro disponível para si e para os dependentes, inclusive receitas de venda de bens pessoais (excetuadas as circunstâncias emergenciais), encontram dificuldades em manter até mesmo o padrão mínimo de vida.

O cálculo dos benefícios é efetuado com base na diferença entre os rendimentos disponíveis (que incluem não apenas os de trabalho remunerado, mas também outros benefícios sociais, como aposentadorias, além daqueles oriundos de auxílio de parentes) e as despesas mínimas de vida, estas definidas pelo próprio Ministério do Bem-Estar Social do Japão. Este montante considerado faltante será então pago como benefício de assistência social pelo governo ${ }^{116}$.

Ressalte-se que esse benefício deve ser definido com base em um estudo meticuloso dos fatores sociais envolvidos na vida do solicitante, como idade, gênero, composição familiar e local de residência, devendo ser o valor suficiente para cobrir o padrão mínimo de vida, mas não podendo excedê-lo ${ }^{117}$.

São os seguintes os benefícios previstos pelo sistema japonês: Assistência à Subsistência, Assistência à Educação, Assistência à Moradia, Assistência Médica, Assistência de Longo Prazo, Assistência à Maternidade, Assistência Ocupacional e Assistência ao Funeral ${ }^{118}$.

\footnotetext{
${ }^{115}$ Nos termos do artigo $2^{\text {o }}$ da Lei de Assistência Pública do Japão. Note-se que os residentes estrangeiros não foram acobertados pela legislação japonesa de assistência social, mas as autoridades japonesas podem ou não conceder o benefício com base em seu entendimento sobre cada caso analisado individualmente, mediante apresentação de documentação comprobatória da necessidade financeira, bem como da intenção de estabelecer residência permanente ou de longo prazo. Fonte: Portal eletrônico da Prefeitura de Shinjuku http://www.city.shinjuku.lg.jp/foreign/english/guide/fukushi/fukushi_9.html (acesso em 14/12/2013).

${ }^{116}$ Fonte: http://www.mhlw.go.jp/english/topics/social_welfare/dl/outline_of_the_public_assistance _system_20101004.pdf Outline of the Public Assistance System, p.2 (acesso em 14/09/2013).

${ }^{117}$ Artigo $8^{\circ}$ da Lei de Assistência Pública do Japão.

${ }^{118}$ Artigo 11 da Lei de Assistência Pública do Japão.
} 
Note-se que todas essas categorias de assistência pública designam benefícios, em regra, fornecidos em forma de pecúnia, sendo que apenas em alguns casos é requerido o fornecimento em outras formas, como serviços.

A Assistência à Subsistência deve cobrir todas as despesas necessárias para manter o padrão mínimo de vida no dia-a-dia do indivíduo, como alimentação, vestuário e transporte. Será fornecida preferencialmente em forma de pecúnia e calculada com base na estrutura doméstica do assistido e fornecida dentro desta própria, sendo que, em caso de impossibilidade ou quando o objetivo da assistência não for dessa maneira atingível, o assistido poderá ser encaminhado a um estabelecimento de reabilitação, assistência, ou outro apropriado, e o benefício será fornecido em forma de serviços ${ }^{119}$.

A Assistência à Educação deve cobrir todas as despesas necessárias para se concluir a educação compulsória, como por exemplo, material escolar, transporte escolar e refeições, entre outras $^{120}$.

A Assistência à Moradia deve permitir a cobertura dos gastos básicos necessários à manutenção da moradia, como despesas de aluguel, reforma da moradia, além de outras necessidades $^{121}$.

Por sua vez, a Assistência Médica deve cobrir exames médicos, remédios e outros materiais terapêuticos, tratamentos médicos e cirurgias ou outros procedimentos, internação hospitalar, acompanhamento médico doméstico e transporte necessário. Os valores devidos pelos serviços e materiais são pagos diretamente aos profissionais ou estabelecimentos hospitalares prestadores dos serviços, sem que algum valor seja desembolsado pelos beneficiários ${ }^{122}$.

\footnotetext{
${ }^{119}$ Artigos 30 e 31 da Lei de Assistência Pública do Japão.

${ }^{120}$ Artigo 32 da Lei de Assistência Pública do Japão.

${ }^{121}$ Artigo 33 da Lei de Assistência Pública do Japão.

${ }^{122}$ Fonte:

http://www.mhlw.go.jp/english/topics/social_welfare/dl/outline_of_the_public_assistance_system_20101004.pdf Outline of the Public Assistance System, p.3 (acesso em 16/09/2013).
} 
Diferente das outras formas de assistência, esta deve ser fornecida preferencialmente em forma de serviços ${ }^{123}$.

A Assistência de Longo Prazo é voltada principalmente aos idosos (será tratada a seguir neste trabalho) ${ }^{124}$.

A Assistência à Maternidade prevê cobertura para os gastos ligados ao procedimento do parto e dos cuidados antes e após o nascimento do bebê ${ }^{125}$.

A Assistência Ocupacional tem por objetivo cobrir os gastos necessários ao desenvolvimento de uma ocupação pelo indivíduo, de modo que este consiga atingir um nível de renda suficiente para manter o padrão mínimo de vida, por exemplo, cobrindo despesas de instrução e de aquisição de material de trabalho ${ }^{126}$.

A última das formas de assistência previstas, a Assistência ao Funeral, tem por intuito acobertar todas as despesas funerárias, desde o exame médico do corpo, transporte, funeral, enterro ou cremação ${ }^{127}$.

O sistema de assistência pública japonês é financiado em parte pelos governos das províncias (em se tratando de povoados e vilas) e pelos governos municipais, que administram escritórios locais de assistência pública. As despesas são subsidiadas também pelo governo nacional ${ }^{128}$.

Por derradeiro, é válido mencionar que é exigido expressamente por lei que o beneficiário de assistência pública empreenda todos os esforços laborais possíveis para reduzir seus gastos, mantendo ou mesmo melhorando seu padrão mínimo de vida ${ }^{129}$. Em termos práticos, este beneficiário deve ser acompanhado de perto pelas autoridades administradoras dos benefícios,

\footnotetext{
${ }^{123}$ Artigo 34 da Lei de Assistência Pública do Japão.

${ }^{124}$ Artigo 34-2 da Lei de Assistência Pública do Japão.

${ }^{125}$ Artigo 35 da Lei de Assistência Pública do Japão.

${ }^{126}$ Artigo 36 da Lei de Assistência Pública do Japão.

${ }^{127}$ Artigo 37 da Lei de Assistência Pública do Japão.

${ }^{128}$ Artigos 70 e seguintes da Lei de Assistência Pública do Japão.

${ }^{129}$ Artigo 60 da Lei de Assistência Pública do Japão.
} 
sendo obrigado a lhes informar qualquer alteração em sua renda, seus gastos ou qualquer outra condição ligada à sua subsistência, até mesmo uma alteração de residência ou composição familiar ${ }^{130}$.

\subsubsection{Assistência de Longo Prazo}

Uma das categorias de assistência pública apontadas anteriormente, a Assistência de Longo Prazo é voltada para a promoção do padrão mínimo de vida em favor de indivíduos que sofrem algum tipo de limitação na realização de tarefas pessoais diárias (por exemplo, ao tomar banho ou realizar refeições), em razão de algum problema de saúde. Na prática, são proporcionados exclusivamente cuidados domésticos que permitam ao paciente se recuperar de uma condição de saúde debilitada, mas não serviços médicos, mesmo aqueles prestados no domicílio, que são acobertados pelo Sistema de Saúde ${ }^{131}$.

A Lei de Assistência de Longo Prazo prevê que esta categoria assistencial forneça benefícios suficientes para satisfazer uma "Condição de Necessidade de Cuidados de Longo Prazo" ou uma "Condição de Ajuda Necessária" da pessoa segurada ${ }^{132}$.

Por Condição de Necessidade de Cuidados de Longo Prazo se entende aquela que requer cuidados contínuos e regulares para todos ou parte dos movimentos requeridos para as tarefas diárias, em razão de problemas físicos ou mentais, nos termos determinados por normativo editado pelo Ministério do Bem-Estar Social, que classificará tal condição de acordo com o nível de necessidade ${ }^{133}$.

Já a Condição de Ajuda Necessária designa aquela que requer cuidados contínuos e regulares que tenham por intuito reduzir ou prevenir o agravamento da necessidade de auxílio para todos ou parte dos movimentos requeridos para as tarefas diárias, em razão de problemas físicos ou

\footnotetext{
${ }^{130}$ Artigo 61 da Lei de Assistência Pública do Japão.

${ }^{131}$ Vide item 3.2 do Capítulo.

${ }^{132}$ Artigo $2^{\circ}$ da Lei de Assistência de Longo Prazo do Japão.

${ }^{133}$ Artigo $7^{\circ}$, caput da Lei de Assistência de Longo Prazo do Japão.
} 
mentais, nos termos determinados por normativo editado pelo Ministério do Bem-Estar Social, que também classificará tal condição de acordo com o nível de necessidade ${ }^{134}$.

Podem requerer Cuidados de Longo Prazo aqueles indivíduos: (i) com mais de 65 anos de idade e que estejam sob a "condição de necessidade dos cuidados de longo prazo" como definida por lei ou (ii) que possuam entre 40 e menos de 65 anos de idade, para os quais os problemas físicos ou mentais que ensejaram a referida condição tenham sido causados por doenças decorrentes de envelhecimento e listadas por normativo do Ministério (aqui chamadas de "doenças específicas") 135 .

Podem requerer a Ajuda Necessária aqueles indivíduos: (i) com mais de 65 anos de idade e que estejam sob a "condição de ajuda necessária" como definida por lei ou (ii) que possuam entre 40 e menos de 65 anos de idade, para os quais os problemas físicos ou mentais que ensejaram a referida condição tenham sido causados por "doenças específicas" ${ }^{136}$.

$\mathrm{Na}$ prática, existem diversos tipos de serviços de assistência de longo prazo ou de ajuda necessária (preventivos), classificados de acordo com o nível de necessidade do indivíduo, que deve solicitar a emissão de um laudo médico atestando tal condição e aguardar a emissão de um "Certificado de Necessidade de Cuidados de Longo Prazo" pelo governo. Após, a condição é classificada entre seis níveis de cuidados de longo prazo, dois níveis de mera ajuda preventiva e, ainda, indivíduos a serem inscritos em projetos de cuidados de longo prazo, por estarem sob risco de adquirir uma dessas duas condições.

O objetivo é permitir que o indivíduo necessitado retorne ou se adapte da forma mais eficiente e rápida possível à vida independente, em um momento onde a condição de necessidade de cuidados de longo prazo é ainda passível de prevenção. Para tanto, estão previstos serviços de cuidados a serem prestados mediante solicitação e autorização tanto dentro da residência do próprio assistido quanto em estabelecimentos adequados para tais demandas, ou até mesmo serviços comunitários. Como exemplos, é possível realizar desde simples serviços de cuidados

\footnotetext{
${ }^{134}$ Artigo $7^{\circ}$, II da Lei de Assistência de Longo Prazo do Japão.

${ }^{135}$ Artigo $7^{\circ}$, III da Lei de Assistência de Longo Prazo do Japão.

${ }^{136}$ Artigo $7^{\circ}$, IV da Lei de Assistência de Longo Prazo do Japão.
} 
pessoais até visitas periódicas de acompanhamento médico, ou até mesmo internação em casas de saúde para idosos.

De acordo com o relatório governamental de 2011-2012, havia mais de 29 milhões de segurados beneficiados pela Assistência de Longo Prazo com pelo menos 65 anos de idade (segurados primários) e quase 43 milhões de segurados beneficiados com idade entre 40 e 64 anos de idade (segurados secundários) ${ }^{137}$.

Cerca de metade dos custos dessa categoria de Assistência Pública é financiada pelos governos municipais, provinciais e o nacional, enquanto o restante tem por fonte o recolhimento de contribuições de assistência pelos governos locais e deduções das aposentadorias dos indivíduos, quando não uma coparticipação dos segurados nos serviços médicos prestados (como prevê o Seguro Saúde Corporativo e o Seguro Saúde Nacional) ${ }^{138}$.

As contribuições variam de acordo com o município gestor e são vinculadas à renda do indivíduo (estão previstos seis níveis de faixas de contribuição para pessoas de pelo menos 65 anos de idade e, para pessoas entre 40 e 64 anos de idade, aplica-se 1\% sobre a renda, limitado a um teto). Uma coparticipação de $10 \%$ é aplicada a todos os tipos de serviços acobertados, sendo também limitada a um teto de acordo com a renda ${ }^{139}$.

\subsection{Seguro Emprego}

Aplicável a todos os trabalhadores no geral, tem por objetivo assegurar que o trabalhador desempregado disponha de meios de subsistência enquanto busca a recolocação profissional. Os trabalhadores em tempo parcial, entretanto, são qualificados ao benefício somente se a sua jornada de trabalho tenha correspondido a pelo menos 20 horas por semana e tenham trabalhado por pelo menos 31 dias na empresa.

\footnotetext{
${ }^{137}$ Fonte: http://www.mhlw.go.jp/english/wp/wp-hw6/dl/10e.pdf (acesso em 22/09/2013).

${ }^{138}$ Fonte: http://www.mhlw.go.jp/english/policy/care-welfare/care-welfare-elderly/dl/ri_130311-01.pdf Relatório do MHLW de 7 de Março de 2013 intitulado: "A situação atual e o futuro do Sistema de Assistência de Longo Prazo do Japão" (acesso em 22/09/2013).

${ }^{139}$ Ryozo Matsuda, p. 68.
} 
O valor do prêmio é calculado com base no salário do trabalhador e os percentuais são determinados de acordo com a categoria profissional ${ }^{140}$.

Os valores dos benefícios variam conforme a razão do desemprego, o período de pagamento do prêmio, a idade do segurado, entre outras variáveis. Assim, por exemplo, se o desemprego decorreu da falência da empresa ou do vencimento do contrato de trabalho por tempo determinado, o benefício será concedido por mais tempo do que nos casos de demissão involuntária. Quanto maior a idade do segurado e maior o tempo de contribuição, maior será também o número de dias de concessão do benefício. Em regra, o valor varia de $50-80 \%$ do valor médio do salário do segurado nos últimos seis meses anteriores ao desemprego.

\subsection{Seguro Acidente de Trabalho}

Trata-se de uma indenização paga a trabalhadores vítimas de acidentes sofridos ou doenças contraídas no exercício de sua função ou no trajeto de ida/retorno do trabalho, que venham a lhes causar incapacidade laboral temporária ou permanente, ou até mesmo a morte.

Os valores dos benefícios são pagos conforme a gravidade dos danos sofridos pelo trabalhador. Assim, por exemplo, há cobertura para as despesas médicas incorridas e paga-se uma indenização conforme os dias não trabalhados em razão do acidente/doença (calculada multiplicando-se o número de dias afastados pelo valor base do benefício, normalmente correspondente a $60 \%$ do valor diário do salário médio do indivíduo). Em caso de falecimento do trabalhador, está previsto o pagamento de uma indenização em valor único ${ }^{141}$.

Os prêmios são calculados sobre a remuneração do trabalhador e o percentual varia conforme a categoria profissional $^{142}$. São pagos integralmente pelos empregadores.

\footnotetext{
${ }^{140}$ Desde a última revisão, em abril/2012, a alíquota do prêmio é de $1,35 \%$, dos quais $0,85 \%$ é pago pelo empregador e $0,5 \%$ pelo trabalhador. Cf. Investing in Japan, item 4.9.3.

${ }_{141}$ Fonte: http://www.mhlw.go.jp/english/org/policy/p19.html

${ }^{142}$ Atualizado em abril/2013, a alíquota máxima do prêmio é de 8,9\% (construções de usinas hidroelétricas) e a mínima é de 0,25\% (serviços financeiros, de seguros e de telecomunicações). Cf. Investing in Japan, item 4.9.2.
} 


\section{CAPÍTULO V - DA RELAÇÃO ENTRE OS SISTEMAS DE SEGURIDADE SOCIAL DO BRASIL E DO JAPÃO}

1. Do tratamento em matéria de seguridade social conferido aos brasileiros residentes no Japão e aos japoneses residentes no Brasil

Como já afirmado em partes anteriores deste trabalho, é sabido que o Brasil e o Japão assinaram um acordo bilateral em matéria previdenciária, razão pela qual o tema da previdência, em específico, será realçado em um item apartado abaixo.

Contudo, observe-se que o acordo em questão, diferentemente de outros assinados pelo Brasil $^{143}$, não previu o acesso dos residentes de nacionalidade japonesa ao serviço público de saúde no Brasil. Este ponto já foi analisado quanto aos trabalhadores estrangeiros residentes no Japão ${ }^{144}$, aos quais o governo japonês recomenda fortemente a adesão ao Seguro Saúde dos Empregados ou ao Seguro Saúde Nacional ${ }^{145}$.

No que tange ao acesso à assistência social pública por residentes estrangeiros no Japão, verificou-se que os casos podem ser analisados individualmente e sujeitos ao juízo das autoridades responsáveis $^{146}$.

Por sua vez, o acesso dos residentes estrangeiros à assistência social no Brasil é considerado ponto mais controvertido, tendo sido inclusive reconhecido como o Tema de Repercussão Geral de $n^{\circ} 173$ no âmbito do Supremo Tribunal Federal, quando fora trazida à pauta o julgamento do Recurso Extraordinário $\mathrm{n}^{\circ}$ 587.970/SP. O recurso em questão levantou a discussão sobre o acesso dos estrangeiros ao benefício assistencial de prestação continuada,

\footnotetext{
${ }^{143}$ Os acordos previdenciários assinados com o Chile e Portugal, por exemplo, preveem o acesso dos residentes das nacionalidades chilena e portuguesa, respectivamente, ao Sistema Único de Saúde (SUS) no Brasil.

${ }^{144}$ V. Capítulo IV, item 3.2.

${ }^{145}$ Guide to living in Japan, p. 12, elaborado pelo Ministério das Relações Exteriores do Japão. Fonte: http://www.mofa.go.jp/j_info/visit/visa/pdfs/guide_living_en.pdf (acesso em 15/12/2013).

${ }^{146}$ V. Capítulo IV, item 3.3.
} 
previsto no inciso $\mathrm{V}$ do art. 203 da $\mathrm{CF} / 88$. O acórdão que reconheceu a repercussão foi publicado em 02/10/2009. Até o presente aguarda-se a conclusão do julgamento do mérito ${ }^{147}$.

2. Da igualdade de tratamento em matéria de previdência conferida aos brasileiros residentes no Japão

No âmbito da OIT, em termos de ratificação da Convenção $n^{\circ} 102$ de 1952, que trata das "Normas Mínimas da Seguridade Social", tanto o Brasil quanto o Japão deixaram de reconhecer sua Parte XII, a qual diz respeito à "Igualdade de Tratamento dos Residentes Estrangeiros" $" 148$.

Vale mencionar ainda que a Convenção n 118 da OIT de 1962, que trata da "Igualdade de Tratamento entre Nacionais e Estrangeiros em Previdência Social”, fora ratificada pelo Brasil em 24/03/1968. Contudo, o Japão não a ratificou até o momento ${ }^{149}$.

De toda sorte, a Constituição do Japão aplica sua garantia à previdência social indistintamente aos nacionais e aos estrangeiros, em face da cláusula de proteção aos direitos humanos naturalmente estendida aos estrangeiros, razão pela qual o trabalhador brasileiro residente tem o direito de ser acobertado pelo Sistema da Previdência Social do Japão. Não bastasse essa garantia constitucional, mesmo as legislações infraconstitucionais trabalhistas proíbem a discriminação com base na nacionalidade, a exemplo da Lei de Normas Trabalhistas ${ }^{150}$.

\footnotetext{
${ }^{147}$ Fonte:

http://www.stf.jus.br/portal/jurisprudenciaRepercussao/listarProcesso.asp?numero=\&numeroTemaInicial=173\&n $\underline{\text { umeroTemaFinal }=173 \& \text { txtTituloTema }=\& \text { classeProcesso }=\& \text { numeroProcesso }=\& \text { ministro }=\& \text { situacaoRG }=\& \text { dataIni }}$ cioRG $=\&$ dataFinalRG $=\&$ merito $=\&$ dataInicialMerito $=\&$ dataFinalMerito $=\& q u e s t a o$ Ord $=\&$ ordenacao $=$ asc $($ acesso em 15/12/2013).

${ }^{148}$ O Brasil ratificou esta Convenção em 15/06/2009 e reconheceu as Partes II a X, ao passo que o Japão a ratificara em 02/02/1976, tendo reconhecido as Partes III a VI (a Parte VI não é aplicável ao Japão por força da ratificação da Convenção $\mathrm{n}^{\circ}$ 121, "Benefícios concedidos em razão de Acidentes de Trabalho". Obs.: A Convenção $\mathrm{n}^{\circ}$ 121 não foi ratificada pelo Brasil). Fonte: http://www.ilo.org/dyn/normlex/en/f?p=1000:11300:0::NO:11300:P11300_INSTRUMENT_ID:312247Ａ transcrição da Convenção ${ }^{\circ} 102$ pode ser conferida nos Anexos deste trabalho.

${ }^{149}$ Fonte: http://www.ilo.org/dyn/normlex/en/f?p=NORMLEXPUB:12100:0::NO::P12100_ILO_CODE:C118

${ }^{150}$ Determina o artigo $3^{\circ}$ da Lei de Normas Trabalhistas (Lei ${ }^{\circ} 49$ de 1947): "O empregador está proibido de aplicar tratamento discriminatório a qualquer trabalhador no que se refere a salário, horas de trabalho ou outras condições de trabalho com justificativas baseadas em nacionalidade, crença ou classe social". Fonte: http://www.jil.go.jp/english/archives/library/documents/llj_law1-rev.pdf
} 
Finalmente, o próprio Acordo Previdenciário Brasil-Japão (em seu Artigo $4^{\circ}$ ) prevê a igualdade de tratamento em matéria previdenciária para os nacionais de ambos os países.

\section{Do Acordo Previdenciário Brasil-Japão}

A fim de regulamentar os direitos de seguridade social previstos nas legislações dos dois países, o Japão e o Brasil assinaram entre si o acordo internacional de previdência social, em vigor desde março de 2012. A promulgação de convênios internacionais nessa matéria possibilitou dirimir questões recorrentes como o cálculo da pensão e o aproveitamento de contribuições efetuadas por trabalhadores estrangeiros.

Foram assinados pelo Japão, até o presente, tratados com os seguintes países ${ }^{151}$ : Alemanha, Reino Unido, Estados Unidos, Coréia do Sul, Bélgica, França, Canadá, Austrália, Países Baixos, República Checa, Espanha, Brasil, Irlanda, Suíça e Itália.

Por sua vez, o Brasil possui acordos bilaterais ${ }^{152}$ com Alemanha, Cabo Verde, Chile, Espanha, Grécia, Itália, Japão, Luxemburgo e Portugal, além de ser signatário da Convenção Multilateral Iberoamericana de Segurança Social ${ }^{153}$ e do Acordo Multilateral de Seguridade Social do Mercado Comum do Sul ${ }^{154}$.

Vide também: http://www.mhlw.go.jp/bunya/koyou/gaikokujin14/dl/portuguese3.pdf (Orientação do Ministério do Trabalho do Japão para os trabalhadores estrangeiros temporários ou empregados de empreiteiras).

${ }^{151}$ Os tratados assinados com o Reino Unido, Coréia do Sul e Itália compreendem tão-somente a eliminação da dupla imposição contributiva, mas não o reconhecimento do total do período contributivo. Fonte:

http://www.nenkin.go.jp/n/www/english/detail.jsp?id=33 (acesso em 15/12/2013). O Acordo com a Itália ainda não entrou em vigor. Todos os acordos assinados podem ser conferidos em: http://www.nenkin.go.jp/n/www/english/detail.jsp?id=34 (acesso em 15/12/2013).

${ }^{152}$ Os acordos com a Bélgica, Canadá, Coreia (República da Coreia ou Coreia do Sul), França e Québec aguardam ratificação pelo Congresso Nacional. Fonte: http://www.previdencia.gov.br/a-previdencia/assuntosinternacionais/assuntos-internacionais-acordos-internacionais-portugues/ (consultado em 15/12/2013).

${ }^{153}$ Vigente para os seguintes países, além do Brasil: Bolívia, Chile, Equador, Espanha, Paraguai e Uruguai.

${ }^{154}$ Os outros signatários são a Argentina, Paraguai e Uruguai. 
O presente Acordo Previdenciário abrange os seguintes programas brasileiros ${ }^{155}$, exclusivamente: a Aposentadoria por Idade, a Aposentadoria por Invalidez e a Pensão por Morte, no âmbito do Regime Geral de Previdência Social (RGPS) ${ }^{156}$.

Para que o segurado (japonês ou brasileiro) possa usufruir desses benefícios, é preciso atender às condições já estabelecidas na legislação brasileira ${ }^{157}$.

Portanto, no que se refere à Aposentadoria por Idade, a pensão será devida ao requerente que completar 65 anos de idade, se homem, ou 60 anos, se mulher, além de cumprir a carência de 180 contribuições. Na Aposentadoria por Invalidez, a pensão será devida ao segurado que houver comprovado sua incapacidade laboral por meio de exame médico pericial e cumprido a carência de 12 contribuições. Por fim, a Pensão por Morte será devida ao conjunto de dependentes do segurado que falecer, sendo este aposentado ou não.

A aplicação do Acordo é abordada a seguir.

\subsection{Da aplicação do Acordo Previdenciário aos brasileiros residentes no Japão}

A Agência da Previdência Social de Atendimento de Acordos Internacionais de São Paulo (APSAI/SP) é responsável pela administração dos benefícios concedidos com base nos acordos previdenciários assinados com o Japão e também com Portugal, mas o segurado também pode solicitar o benefício em qualquer Agência da Previdência Social (APS) do Brasil, se residente no Brasil, ou em qualquer unidade do Serviço Japonês de Aposentadoria (JPS), se residente no Japão, onde deve entregar o formulário de solicitação e a documentação ${ }^{158}$.

\footnotetext{
155 O Acordo compreende estes programas japoneses: a Aposentadoria Nacional, o Seguro e Aposentadoria dos Trabalhadores Empregados e as Associações de Auxílio Mútuo.

${ }^{156} \mathrm{E}$ também no regime dos militares e no regime próprio dos servidores públicos.

${ }^{157}$ Tratadas no Capítulo II deste trabalho.

${ }^{158}$ Todos os formulários podem ser encontrados em: http://www.previdencia.gov.br/formulrios-brasil-japo/ .

Para os trabalhadores brasileiros residentes no Japão, orientações sobre os procedimentos com relação ao Acordo e os formulários estão em: http://www.nenkin.go.jp/n/www/english/detail.jsp?id=37

Em se tratando de benefícios a serem remetidos ao Japão, o cálculo é feito pelo INSS no último dia útil do mês e o câmbio utilizado será o da data da remessa efetuada pelo Banco do Brasil. A informação pôde ser conferida na palestra apresentada em 15/07/2012 por Belara Giraldelo, Gerente da APSAI/SP, por ocasião do Simpósio
} 
Após receber a solicitação e a documentação, a APS as encaminhará à APSAI/SP que, posteriormente, se comunicará com o Serviço Japonês de Aposentadoria (JPS) para buscar a certificação do tempo de contribuição para o cálculo dos benefícios. Por sua vez, no Japão, é o JPS que solicitará todas as informações necessárias sobre o requerente à APSAI/SP, que as obtém consultando o Cadastro Nacional de Informações Sociais - CNIS.

Vale mencionar que o trabalhador brasileiro deslocado para o Japão a trabalho pode ser dispensado de filiação e/ou isento de contribuição nesse país de destino, permanecendo vinculado ao regime previdenciário do Brasil (país de origem), mediante solicitação de seu empregador junto à APSAI/SP ou uma das APS, que fornecerá o Certificado de Deslocamento Temporário. O prazo inicial do deslocamento pode ser de até cinco anos, prorrogáveis em situações especiais por um período de até três anos. É necessário aguardar um ano entre o último deslocamento e a nova solicitação.

Ainda a respeito da atuação da APSAI/SP, a título de conhecimento, foram concedidos 488 benefícios no âmbito do Acordo Brasil-Japão na competência de novembro de 2013, resultando em um total líquido de $\mathrm{R} \$ 576.420,85$ (quinhentos e setenta e seis mil, quatrocentos e vinte reais e oitenta e cinco centavos), que chegaram a mais de 25 milhões de ienes ${ }^{159}$. Comparativamente, foram concedidos 8.282 benefícios no âmbito do Acordo BrasilPortugal $^{160}$, somando R $\$ 10.871 .910,74$ (dez milhões e oitocentos e setenta e um mil, novecentos e dez reais e setenta e quatro centavos) ${ }^{161}$.

Para fins de cálculo do salário-de-benefício da Aposentadoria por Idade e da Aposentadoria por Invalidez, o número de contribuições efetuadas não afetará o valor da pensão, pois somente o tempo de contribuição será utilizado para o reconhecimento do direito ao benefício, seja no Japão, seja no Brasil.

Internacional do CIATE de 2012. Fonte: http://www.ciate.org.br/noticias/200-perguntas-e-respostas-sobreacordo-previdenciaria-brasil-japao-na-ocasiao-do-simposio-internacional-do-ciate-15-de-julho-de-2012

${ }^{159}$ Para 29/11/ 2013, considere-se 1 BRL $=44,19$ JPY

${ }^{160}$ Em vigor desde 1995.

${ }^{161}$ Dados fornecidos por Belara Giraldelo, Gerente da APSAI/SP, em entrevista pessoal realizada em dezembro de 2013. Para se ter uma ideia sobre o aumento da demanda pela aplicação do Acordo, entre março de 2012 e abril de 2013 apenas 273 benefícios haviam sido concedidos, além de 51 pedidos de deslocamento temporário de empregados do Brasil para o Japão. Fonte: http://blog.previdencia.gov.br/?p=7167\#more-7167 (acesso em 29/12/2013). 
$\mathrm{Na}$ prática, o segurado poderá solicitar o benefício com ou sem a "totalização", assim denominado o cômputo do tempo de contribuição nos dois países para fins de cálculo do benefício, nos conformes do Acordo. Em outras palavras, quando o segurado solicitar no Brasil a Aposentadoria por Idade, por exemplo, mas o seu tempo de contribuição do Brasil não chegar a 180 contribuições (15 anos), poderá o tempo de contribuição no Japão ser incluído na soma, resultando assim em um total de 180 contribuições (note-se que aqui será considerado tão-somente o período de tempo faltante).

Antes de adentrar no cálculo da totalização, abre-se aqui um necessário parêntese lembrando que as regras acima se aplicarão à Pensão por Morte na medida em que houver a necessidade de se determinar o salário-de-benefício ${ }^{162}$. Isso porque o benefício em questão consiste em uma renda mensal equivalente a $100 \%$ do valor da aposentadoria que o segurado recebia ou daquela a que teria direito se estivesse aposentado por invalidez na data de seu falecimento.

\subsubsection{Cálculo do benefício sem totalização}

Antes de tudo, lembre-se que o valor da renda mensal do benefício da prestação continuada é obtido com base no salário-de-benefício.

Para o cálculo do salário-de-benefício sem totalização e aplicável aos inscritos na previdência social até 28/11/1999, será utilizada a média aritmética simples dos maiores salários-decontribuição, correspondentes ao mínimo de 80\% do período decorrido desde julho de 1994 até a data de início do benefício, em se tratando da Aposentadoria por Idade ${ }^{163}$ e da Aposentadoria por Invalidez ${ }^{164}$.

\footnotetext{
${ }^{162}$ Conforme art. $39, \S 3^{\circ} \mathrm{c} / \mathrm{c}$ art. 106, caput do Decreto $\mathrm{n}^{\circ} 3.048 / 99$.

${ }^{163}$ Nos termos do art. $188-\mathrm{A}, \S 1^{\circ}$ do Decreto $\mathrm{n}^{\circ} 3.048 / 99$, o divisor utilizado na obtenção dessa média aritmética não poderá ser inferior a $60 \%$ do período decorrido da competência julho de 1994 até a data de início do benefício, limitado a $100 \%$ de todo o período contributivo. Aqui, o fator previdenciário será aplicado de forma progressiva, incidindo sobre um sessenta avos dessa média aritmética por competência que se seguir a 28 de novembro de 1999, cumulativa e sucessivamente, até completar sessenta sobre sessenta avos da referida média, na competência de novembro de 2004, como prevê o art. 188-A, $\S 2^{\circ}$ do Decreto $n^{\circ} 3.048 / 99$.

${ }^{164}$ Conforme o art. $188-\mathrm{A}, \S 4^{\circ}$ do Decreto ${ }^{\circ} 3.048 / 99$.
} 
E caso não haja contribuições depois de julho de 1994, o valor do benefício será equivalente ao mínimo do salário-de-benefício ${ }^{165}$.

Aos inscritos na previdência social a partir de 29/11/1999, será aplicada a regra geral do cálculo do salário-de-benefício. Assim sendo, em se tratando da Aposentadoria por Idade, o salário-de-benefício será determinado com base na média aritmética simples dos maiores salários-de-contribuição correspondentes a $80 \%$ de todo o período contributivo ${ }^{166}$. Já na Aposentadoria por Invalidez, será utilizada a média aritmética simples dos maiores saláriosde-contribuição correspondentes a $80 \%$ de todo o período contributivo ${ }^{167}$.

A renda mensal do benefício de prestação continuada será calculada aplicando-se sobre o salário-de-benefício os seguintes percentuais: (i) para a Aposentadoria por Invalidez, 100\%, e (ii) para a Aposentadoria por Idade, $70 \%$ mais $1 \%$ para cada grupo de 12 contribuições mensais, limitado a $30 \%{ }^{168}$.

Por fim, destaque-se que essa renda mensal não poderá ser inferior ao salário mínimo nem superior ao limite máximo do salário-de-contribuição ${ }^{169}$.

\footnotetext{
${ }^{165}$ Conforme o art. 188-E do Decreto $\mathrm{n}^{\circ}$ 3.048/99. Como se verá logo em seguida, o valor será de um salário mínimo.

${ }^{166}$ Essa média poderá ou não ser multiplicada ou não pelo fator previdenciário, conforme for mais vantajoso para o segurado que solicita a Aposentadoria por Idade, nos termos do art. 32, I c/c art. 181-A do Decreto ${ }^{\circ}$ 3.048/99. ${ }^{167}$ Conforme o art. 32, II do Decreto $n^{\circ} 3.048 / 99$.

${ }^{168}$ Conforme o art. 39, II e III do Decreto n ${ }^{\circ} 3.048 / 99$.

${ }^{169}$ Nos termos do art. $32, \S 3^{\circ}$ do Decreto ${ }^{\circ}$ 3.048/99: "O valor do salário-de-benefício não será inferior ao de um salário mínimo, nem superior ao limite máximo do salário-de-contribuição na data de início do benefício”. Cf. também o art. 35, caput do Decreto n 3.048/99.
} 
3.1.2 Cálculo do benefício com totalização (quando são considerados os tempos de contribuição em ambos os países)

Para o cálculo do salário-de-benefício com totalização, há três hipóteses diferentes previstas em lei.

$\mathrm{Na}$ primeira delas, quando o segurado houver contribuído no Brasil em número igual ou superior a 60\% do número de meses decorridos desde a competência julho de 1994, aplicar-seão as mesmas regras previstas quanto ao cálculo sem totalização ${ }^{170}$.

Desse modo, aos inscritos na previdência social até 28/11/1999, será utilizada a média aritmética simples dos maiores salários-de-contribuição, correspondentes ao mínimo de $80 \%$ do período decorrido desde julho de 1994 até a data de início do benefício, em se tratando da Aposentadoria por Idade e da Aposentadoria por Invalidez.

Aos inscritos na previdência social a partir de 29/11/1999, o salário-de-benefício da Aposentadoria por Idade será determinado com base na média aritmética simples dos maiores salários-de-contribuição correspondentes a $80 \%$ de todo o período contributivo. Para a Aposentadoria por Invalidez, será utilizada a média aritmética simples dos maiores saláriosde-contribuição correspondentes a $80 \%$ de todo o período contributivo.

Na segunda hipótese, quando o segurado houver contribuído no Brasil em número inferior a $60 \%$ do número de meses decorridos desde a competência julho de 1994, o salário-decontribuição será calculado com base no valor da média aritmética simples de todos os salários-de-contribuição correspondentes a todo o período contributivo contado desde julho de $1994^{171}$.

De outra forma, a terceira hipótese prevê o caso em que o segurado não houver contribuído no Brasil desde julho de 1994, quando o salário-de-contribuição também será calculado com base

\footnotetext{
${ }^{170}$ Conforme o art. 32, $\S 18, \mathrm{I}$ do Decreto $\mathrm{n}^{\circ} 3.048 / 99$.

${ }^{171}$ Conforme o art. 32, $\$ 18$, II do Decreto ${ }^{\circ} 3.048 / 99$.
} 
na média aritmética simples de todo o período contributivo, multiplicado pelo fator previdenciário $^{172}$.

A renda mensal do benefício de prestação continuada, como no cálculo do benefício sem totalização, será calculada aplicando-se sobre o salário-de-benefício os seguintes percentuais: (i) $100 \%$ para a Aposentadoria por Invalidez, e (ii) $70 \%$ mais $1 \%$ para cada grupo de 12 contribuições mensais, limitado a $30 \%$, para a Aposentadoria por Idade ${ }^{173}$.

Entretanto, note-se que a renda mensal obtida pelo cálculo com totalização, diferentemente do cálculo sem totalização, poderá ser inferior ao salário mínimo ${ }^{174}$.

Para melhor compreensão do cálculo, dois exemplos serão apresentados abaixo ${ }^{175}$.

\section{Aposentadoria por Idade}

Supondo-se que um segurado, inscrito na Previdência Social brasileira em 07/1997, tenha completado 65 anos de idade em 07/2008, vindo a solicitar a aposentadoria por idade em 03/2012, quando entrou em vigor o Acordo Previdenciário Brasil-Japão.

Tendo contribuído no Brasil no período de 07/1997 a 06/2008 (132 contribuições mensais ou equivalente a 11 anos, o "tempo de serviço no Brasil") e no Japão de 01/1993 a 12/1996 (48 contribuições mensais ou equivalente a 4 anos). Assim, o tempo de contribuição total nos dois países em 07/2008 era de 180 contribuições mensais ou 15 anos ("tempo total de serviço").

Porém, para calcular o valor do benefício, serão utilizadas apenas as 132 contribuições mensais no Brasil.

Por se tratar de um segurado inscrito até 28/11/1999, será aplicada a média aritmética simples dos maiores salários-de-contribuição, correspondentes ao mínimo de $80 \%$ do período

\footnotetext{
${ }^{172}$ Conforme art. 32, §18, III do Decreto $\mathrm{n}^{\circ} 3.048 / 99$.

${ }^{173}$ Conforme o art. 39, II e III do Decreto n ${ }^{\circ} 3.048 / 99$.

${ }^{174}$ Conforme o art. $35, \S 1^{\circ}$ do Decreto ${ }^{\circ} 3.048 / 99$.

${ }^{175}$ Extraídos da Cartilha Explicativa - Acordo Brasil Japão e discutidas em entrevista pessoal com Belara Giraldelo, Gerente da APSAI/SP.
} 
decorrido desde julho de 1994 até a data de início do benefício para se determinar o salário-debenefício. Assim, 80\% x $132=106$ contribuições mensais. Supõe-se aqui que essas 106 contribuições mensais, corrigidas mensalmente, somam R\$371.056,10.

Para se chegar à renda mensal do benefício, serão aplicados $70 \%$ mais $1 \%$ para cada grupo de 12 contribuições mensais, limitados a 30\%, sobre esse salário-de-benefício. Como há 180 contribuições mensais ou 15 grupos de 12 contribuições mensais, são 15 x 1\% = 15\% mais os $70 \%$, chegando-se em $85 \%$.

Logo, 85\% x R \$ 371.056,10 / $106=\mathrm{R} \$ 2.975,45$, chamada pelo Acordo de "prestação teórica".

Finalmente, chega-se à chamada "prestação proporcional", que é o valor a ser efetivamente pago ao segurado, dessa forma: $\mathrm{R} \$ 2.975,45 \times 11 / 15=\mathrm{R} \$ 2.181,99$ (renda mensal), sendo 11 o "tempo de serviço no Brasil" e 15 o "tempo total de serviço".

\section{$\underline{\text { Aposentadoria por Invalidez }}$}

Nesse próximo exemplo, supõe-se que um indivíduo contribuiu no Brasil de 01/1998 a 01/1999, período equivalente a 13 contribuições mensais. Entretanto, adoeceu com fixação da "data de início da incapacidade" (DII, como denominado pelo INSS) em 01/12/2009, ou seja, mais de 10 anos após a última contribuição no Brasil, tendo perdido a qualidade de segurado, em teoria.

Lembre-se que a qualidade de segurado é mantida pelo período de até 12 meses após a cessação das contribuições ${ }^{176}$. Para que o requerente possa receber o benefício, não basta que sua incapacidade permanente tenha sido atestada por perícia médica e que a carência de 12 contribuições tenha sido cumprida, também sendo necessário que tenha mantido a qualidade de segurado.

Por outro lado, supondo-se que nesse caso o indivíduo também tenha contribuído no Japão de 01/2008 a 11/2009 (um total de 23 contribuições mensais), ele terá readquirido a qualidade de

\footnotetext{
${ }^{176}$ Conforme o art. 13 do Decreto ${ }^{\circ} 3.048 / 99$.
} 
segurado porque contribuiu para a previdência social do país acordante, o Japão, com pelo menos 1/3 das contribuições necessárias para atingir a carência da aposentadoria por invalidez, ou seja, $1 / 3$ de $12=4$ contribuições, uma condição prevista pela legislação brasileira ${ }^{177}$.

Aqui, a carência já havia sido recuperada em 05/2008, após o indivíduo ter efetuado 4 contribuições à previdência social japonesa. Logo, quando a DII fora fixada em 01/12/2009, a qualidade de segurado já havia sido readquirida.

Para o cálculo desse benefício, seria utilizada a média aritmética simples dos maiores saláriosde-contribuição, correspondentes ao mínimo de $80 \%$ do período de contribuição de 01/1998 a 11/2009 (o "período básico de contribuição"). Como o segurado não atingiu esse mínimo de $80 \%$, o cálculo da média seria simples, utilizando as contribuições efetuadas no Brasil. O resultado dessa média seria o salário-de-benefício.

Exclusivamente para o cômputo da totalização nesse caso, seriam utilizadas as 4 contribuições imediatamente anteriores à fixação da DII, ou seja, aquelas feitas de 08/2009 a 11/2009 no Japão.

Após a obtenção do salário-de-benefício, seria então aplicada a fórmula: salário-de-benefício x tempo de serviço no Brasil / tempo total de serviço no Japão e no Brasil. Nesse caso, o tempo de serviço no Brasil seria de 13 contribuições mensais (de 01/1998 a 01/1999), enquanto o tempo de serviço no Japão seria de 4 contribuições mensais (de 08/2009 a 11/2009). Portanto, o tempo total de serviço no Brasil e no Japão equivaleria a $13+4=17$ contribuições mensais e, nesse exemplo, o segurado receberia o equivalente a 13/17 avos do salário-de-benefício.

Por fim, é necessário ainda atentar para um aspecto importante da totalização das contribuições. Como já mencionado neste trabalho, os trabalhadores brasileiros que tenham contribuído para a Aposentadoria Nacional e a Aposentadoria dos Empregados no Japão poderão solicitar a retirada dos valores pagos (limitados a três anos ou 36 meses de contribuições), dentro de um período de dois anos após deixar o território japonês ${ }^{178}$. Contudo,

\footnotetext{
${ }^{177}$ Conforme o art. 27-A do Decreto ${ }^{\circ} 3.048 / 99$.

${ }^{178}$ Os formulários podem ser encontrados em http://www.nenkin.go.jp/n/www/english/detail.jsp?id=10.
} 
nesse caso, os valores retirados no Japão não mais poderão ser aproveitados no Brasil para a aplicação da regra da totalização, restando garantida ao segurado a utilização apenas das contribuições pagas no Brasil para o cálculo de seu benefício ${ }^{179}$.

${ }^{179}$ Fonte: http://www.ciate.org.br/noticias/200-perguntas-e-respostas-sobre-acordo-previdenciaria-brasil-japaona-ocasiao-do-simposio-internacional-do-ciate-15-de-julho-de-2012. 


\section{CAPÍTULO VI - CONCLUSÕES}

Diante destas considerações, foi possível observar primeiramente que, em comparação com o sistema de seguridade social brasileiro, o sistema de seguridade social japonês se desenvolveu mais tardiamente, tendo tomado sua forma e fortalecido suas bases somente após a Segunda Guerra Mundial.

Nesse particular, o Brasil já contava desde a década de 20 com caixas de aposentadoria, as quais evoluíram depois para os institutos de aposentadoria e pensão, administrados sob a forma de autarquias federais. Os anos seguintes testemunharam a estatização da gestão do sistema previdenciário brasileiro, destacando-se como um marco importante a promulgação da Constituição Federal de 1934 (anterior à Segunda Guerra Mundial, portanto), que previu expressamente os direitos trabalhistas e previdenciários, além do sistema de gestão estatal e o custeio tripartite. Desde então a seguridade social brasileira tem ampliado sua cobertura e a extensão dos benefícios, acompanhando as décadas de industrialização do país e as demandas do trabalhador brasileiro.

Influenciado por uma realidade muito diferente, o Japão anterior à Segunda Guerra Mundial era fortemente militarizado e, portanto, os primeiros planos de aposentadoria regulamentados eram voltados apenas ao seu corpo militar e aos seus servidores públicos, se estendendo somente depois, aos poucos, às outras categorias profissionais. Os planos de saúde até então eram geridos pelas grandes corporações da época, sem qualquer participação estatal.

Após a Segunda Guerra, um Japão extremamente empobrecido se viu obrigado a promover o acesso da população às condições mínimas de subsistência por meio da ampliação de sua rede de seguridade social, ao mesmo tempo em que precisava estimular a criação de empregos. Foi nesse cenário que o trabalhador japonês se tornou uma figura importante para a seguridade social daquele país. Nas décadas posteriores à recuperação da Segunda Guerra, o Japão ampliou o acesso da população à seguridade social, buscando ao mesmo tempo se adaptar ao seu envelhecimento. 
De um modo geral, tanto no âmbito da seguridade social japonesa quanto na brasileira os benefícios estão categorizados em planos de aposentadoria, programas de saúde e programas de assistência social, sendo que a seguridade japonesa confere um maior grau de atenção à população idosa, refletido no desenvolvimento de programas voltados especialmente a estes indivíduos, a exemplo do Seguro Saúde para a Idade Avançada e da Assistência de Longo Prazo. Embora estes dois programas não encontrem paralelos no Brasil, não é demais lembrar que a população brasileira de idade avançada está resguardada pelos benefícios conferidos a todos em geral, inerentes à preservação dos meios de subsistência (regimes de previdência e programas de saúde e de assistência social).

E por falar em envelhecimento, releva-se o fato da Assistência de Longo Prazo do Japão ser diferente de outros programas de assistência social, na medida em que proporciona ao segurado os cuidados domésticos necessários na realização de tarefas pessoais diárias, possibilitando que o indivíduo contorne seu estado de saúde debilitada. Tal benefício não deixa ser, na realidade, uma proteção à dignidade do idoso assistido.

Em se tratando da Assistência Social, verificou-se que o programa japonês busca quantificar o montante necessário exato para garantir o padrão mínimo de vida do segurado, para tanto levando em consideração neste cálculo desde os fatores sociais que influenciam a vida do indivíduo até a diferença entre os valores das receitas de suas fontes de renda e as despesas mínimas. A Assistência Social brasileira, por sua vez, não calcula os valores dos benefícios financeiros com base nessa diferença valorativa, embora utilize determinados critérios objetivos que considerem a situação individual do segurado, como o número de membros da família e a renda familiar. De toda forma, o valor deste benefício assistencial é fixo (um salário mínimo, em regra) e, portanto, não quantificável com base naqueles critérios.

No que se refere ao Seguro Saúde do Japão, faz-se necessário apontar que, diferente do programa brasileiro, o programa japonês exige de todos os segurados uma coparticipação, em regra, de 30\%. O financiamento se dá em parte pelo governo japonês, em forma de subsídios, e em parte pelos próprios segurados, através das contribuições e de sua coparticipação. Diferentemente, o acesso à Saúde Pública no Brasil pelos segurados é gratuito. 
Outro ponto a ser anotado se refere aos regimes de Previdência Social, cuja classificação no Japão se dá essencialmente em função do vínculo empregatício dos segurados: trabalhadores empregados e servidores públicos estão acobertados pela Aposentadoria dos Empregados, ao passo que os demais indivíduos estão acobertados pela Aposentadoria Nacional, apresentando cada qual desses dois regimes suas próprias condições (idade mínima e carência). No Brasil, todos os segurados estão acobertados via de regra pelo regime geral (RGPS), com exceção dos servidores públicos, assegurados por regimes especiais ou próprios. Sob o RGPS, atuam os diversos programas de previdência brasileiros, cada qual com um suas características e condições particulares.

Nesse aspecto, vale mencionar que o RGPS prevê um número maior de programas que abrangem contingências mais variadas, em comparação com o sistema japonês. Pode ser citada como exemplo a Aposentadoria Especial brasileira, aplicável especificamente a trabalhadores cuja saúde ou integridade física tenha sido prejudicada em razão de exposição prolongada a agentes nocivos, um programa sem equivalente no sistema japonês. Esse tipo de situação não está previsto pelos planos de aposentadoria japoneses, muito embora o sistema japonês, tal como o brasileiro, tenha previsto a Aposentadoria por Invalidez, direcionada a segurados incapacitados para o trabalho.

Por outro lado, o Auxílio-Doença brasileiro, devido a segurados incapacitados para o trabalho por mais de quinze dias consecutivos, poderia ser equiparado, em termos gerais práticos, ao Seguro Acidente de Trabalho japonês, conferido aos trabalhadores afastados do trabalho em razão de acidentes ou doenças. Ambos os programas preveem o pagamento do benefício de acordo com o tempo de afastamento do segurado.

Com relação a outro ponto relevante, pode-se afirmar que o FGTS oferece ao trabalhador segurado uma proteção única, sem igual no sistema japonês, ao garantir em seu nome um patrimônio que poderá ser utilizado em situações imprevisíveis (como a demissão sem justa causa) ou, em último caso, quando da aposentadoria ou falecimento do segurado. Não obstante o trabalhador desempregado estar protegido pelo sistema japonês através do Seguro Emprego, 
este último não apresenta as mesmas características de um fundo patrimonial, sendo acessível apenas quando o risco previsto (desemprego) se concretiza.

É preciso, porém, fazer justiça aos planos contingenciais desenvolvidos pelo governo japonês frente às emergências, a exemplo do Plano de Assistência Médica de Longo Prazo aplicável aos trabalhadores que atuaram no acidente nuclear de Fukushima, em 2011. Frequentemente sujeito a catástrofes como terremotos, maremotos e tufões, entre outras causadas por agentes naturais, o Japão buscou desenvolver uma seguridade social estruturada de modo a garantir a proteção social de sua população nessas situações críticas.

Quanto à aplicação do Acordo Previdenciário Brasil-Japão, permitiu-se considerar para o cálculo da totalização apenas o tempo de contribuição para os planos de aposentadoria pública nos dois países. Em outras palavras, os valores pagos em cada país não poderão ser trazidos ou levados ao outro, mas o segurado poderá, eventualmente, se atendidas as condições, solicitar a aposentadoria por totalização e receber os valores do benefício de acordo com o seu tempo de contribuição em ambos os países.

Entretanto, o Acordo passou ao largo dos benefícios no âmbito da Saúde Pública, não sendo possível que os trabalhadores brasileiros no Japão, que porventura tenham efetuado contribuições aos programas de saúde japoneses, solicitem a restituição desses valores após deixarem o país e retornarem ao Brasil.

Em suma, resguardadas as realidades e os estágios de desenvolvimento diferentes da Seguridade Social do Japão e do Brasil, pode-se concluir que o sistema japonês confere maior atenção aos segurados idosos em comparação com o sistema brasileiro.

Por derradeiro, também é possível afirmar que o Acordo Previdenciário, de certa forma, aplicou um tratamento equitativo para os trabalhadores segurados, em termos de previdência social, garantindo que todos eles possam se aposentar recebendo benefícios de maneira proporcional ao seu tempo de contribuição em qualquer dos dois países. Trata-se de um benefício de essencial importância aos trabalhadores brasileiros que escolheram permanecer no Japão, bem como àqueles que retornam ao Brasil. 


\section{BIBLIOGRAFIA}

\section{$\underline{\text { Livros }}$}

Centenário: Contribuição da Imigração Japonesa para o Brasil Moderno e Multicultural. São Paulo: Paulo’s Comunicação e Artes Gráficas, 2010.

CENTRO DE ESTABILIZAÇÃO DO EMPREGO NAS INDÚSTRIAS. Guia para Trabalhadores Nikkeis. Japão: Centro de Estabilização do Emprego nas Indústrias, 2004.

CIATE: 20 Anos participando da realidade dos trabalhadores brasileiros no Japão (Relatório do Encontro dos Colaboradores Regionais do CIATE - 2012). São Paulo: Centro de Informação e Apoio ao Trabalhador no Exterior - CIATE, 2013.

CORREIA, Marcus Orione Gonçalves. Curso de Direito da Seguridade Social. $5^{\mathrm{a}}$ ed., São Paulo: Saraiva, 2010.

CORREIA, Marcus Orione Gonçalves. Legislação Previdenciária Comentada. $2^{\mathrm{a}}$ ed. revisada e atualizada, São Paulo: DPJ Editora, 2009.

HORVATH JÚNIOR, Miguel. Direito Previdenciário. $8^{\text {a }}$ ed., São Paulo: Quartier Latin, 2010.

MARTINS, Sérgio Pinto. Direito da Seguridade Social. 32ª ed., São Paulo: Atlas, 2012.

NINOMIYA, Masato. Os trabalhadores brasileiros no Japão. In: Relações Sul-Sul - Países da Ásia e do Brasil, org. Alberto do Amaral Junior e Michelle Ratton Sanchez. São Paulo: Aduaneiras, 2004, p. 277-316.

REBICK, Marcus. The Japanese Employment System. United States: Oxford University Press, 2005. 


\section{$\underline{\text { Periódicos }}$}

CORREIA, Marcus Orione Gonçalves. Uma análise comparativa entre o sistema de seguridade social brasileiro e japonês - em busca de soluções para os trabalhadores brasileiros residentes no Japão. Revista de Previdência Social, São Paulo, v. 26, nº 258, maio de 2002, p. 367-372.

OIZUMI, Hiroko. O Sistema da Previdência Social do Japão e as Questões de Aplicabilidade aos Estrangeiros. In: Simpósio Internacional de Direito Comparado: Trabalhadores Brasileiros no Japão, n.8, 26 a 29 de agosto de 2002 em São Paulo/SP e 29 a 31 de agosto de 2002 em Londrina/PR. Relatório do Simpósio Internacional de Direito Comparado: Trabalhadores Brasileiros no Japão. Tokyo: ICCLP Publications, 2003. p. 178-181.

OZAKI, Masatoshi. Trabalhadores Imigrantes e o Seguro Social: Realidade e Questões de Seguro relativas aos Nipo-brasileiros. In: Simpósio Internacional de Direito Comparado: Trabalhadores Brasileiros no Japão, n.8, 26 a 29 de agosto de 2002 em São Paulo/SP e 29 a 31 de agosto de 2002 em Londrina/PR. Relatório do Simpósio Internacional de Direito Comparado: Trabalhadores Brasileiros no Japão. Tokyo: ICCLP Publications, 2003, p. 182195.

OZAKI, Masatoshi. Sobre o Aumento da Demanda da Força de Trabalho Migrante dentro do Avanço da Mudança da Estrutura do Emprego. Relatório do Encontro dos Colaboradores Regionais do CIATE 2006, São Paulo: Centro de Informação e Apoio ao Trabalhador no Exterior - CIATE, 2007, p. 65-97.

SHIMAMURA, Akiyo. Direito dos Idosos à Seguridade Social: Considerações fundamentais com base nos sistemas legais do Brasil e do Chile (tese apresentada, sob orientação do Prof. Masahiko Iwamura, à Universidade de Tóquio para obtenção do título de professor-assistente, com defesa apresentada em 17.02.2012). Tóquio: Revista da Faculdade de Direito da Universidade de Tóquio, Fevereiro de 2013, 340 p. 
$\underline{\text { Meios eletrônicos }}$

CAMPBELL, John Creighton. Japan Social Policy in Comparative Perspective. World Bank Institute - $\quad$ WBI $\quad$ Working $2002 . \quad$ Fonte: http://siteresources.worldbank.org/WBI/Resources/wbi37197.pdf (Acesso em 21/07/2013)

Cartilha Explicativa - Acordo Brasil Japão, Instituto Nacional do Seguro Social. Fonte: http://www.previdencia.gov.br/arquivos/office/3_120224-152610-463.pdf (Acesso em 21/12/2013)

DUELL, Nicola et al., Activation Policies in Japan, OECD Social, Employment and Migration Working Papers, No. 113, OECD Publishing, 2010. Fonte: http://dx.doi.org/10.1787/5km35m63qqvc-en (Acesso em 30/06/2012)

HIGUCHI, Naoto, Brazilian Migration to Japan - Trends, Modalities and Impact. United Nations Secretariat, Expert Group Meeting on International Migration and Development in Latin America and the Caribbean, 27 February 2006. Fonte: http://www.un.org/esa/population/meetings/IttMigLAC/P11_Higuchi.pdf (Acesso em 21/07/2013)

Investing in Japan. 4.9. Japan's Social Security System, Japan External Trade Organization (JETRO), 2012. Fonte: http://www.jetro.go.jp/en/invest/setting_up/laws/section4/page9.html (Acesso em 25/10/2013)

JICA Thematic Guidelines: Social Security (Health Care/Pension/Social Welfare), March 2009, Japan International Cooperation Agency. Fonte: http://www.jica.go.jp/english/our_work/thematic_issues/social/pdf/guideline_social.pdf (Acesso em 08/09/2013)

KAMBAYASHI, Ryo. Dismissal Regulation in Japan. Global COE Hi-Stat Discussion Paper Series 119 - Hitotsubashi University, March 2010. Fonte: http://hermes-ir.lib.hitu.ac.jp/rs/bitstream/10086/18321/1/gd09-119.pdf （Acesso em 11/06/2012)

MARUO, Naomi. Social Security in Japan: Toward a Japanese Model of the Welfare State. In: 1996 Lyon Summit, Japan’s Social Security Initiatives Building a Caring World. Fonte: http://www.mofa.go.jp/j_info/japan/socsec/maruo/maruo_5.html (Acesso em 24/06/2012) 
MATSUDA, Ryozo. International Profiles of Health Care Systems 2012, November 2012, The Commonwealth Fund. Fonte:

http://www.commonwealthfund.org/ /media/Files/Publications/Fund\%20Report /2012/Nov/1645_Squires_intl_profiles_hlt_care_systems_2012.pdf (Acesso em 26/09/2013)

ODAKA, Konosuke. The Evolution of Social Policy in Japan. World Bank Institute - WBI Working Papers, 2002. Fonte: http://siteresources.worldbank.org/WBI/Resources/ wbi37202.pdf (Acesso em 21/07/2013)

Pension Security, Ministério da Saúde, do Trabalho e do Bem-Estar Social do Japão (MHLW). Fonte: http://www.mhlw.go.jp/english/wp/wp-hw6/d1/11e.pdf (Acesso em 25/10/2013)

The point of the pension plan, Ministério da Saúde, do Trabalho e do Bem-Estar Social do Japão (MHLW). Fonte: http://www.mhlw.go.jp/english/org/policy/dl/p36-37_1.pdf (Acesso em 25/10/2013)

Social Security in Japan. National Institute of Population and Social Security Research of Japan (IPSS), March 2011. Fonte: http://www.ipss.go.jp/s-info/e/Jasos2011/ss2011.pdf (Acesso em 14/07/2013)

TAJIKA, Eiji. The Public Pension System in Japan. World Bank Institute - WBI Working Papers, 2002. Fonte: http://siteresources.worldbank.org/WBI/Resources/wbi37203.pdf (Acesso em 16/07/2013) 


\begin{abstract}
$\operatorname{ANEXOS}^{180}$
I) Constituição do Japão de 1947 (em inglês) ${ }^{181}$

Promulgated on November 3, 1946

Came into effect on May 3, 1947

We, the Japanese people, acting through our duly elected representatives in the National Diet, determined that we shall secure for ourselves and our posterity the fruits of peaceful cooperation with all nations and the blessings of liberty throughout this land, and resolved that never again shall we be visited with the horrors of war through the action of government, do proclaim that sovereign power resides with the people and do firmly establish this Constitution. Government is a sacred trust of the people, the authority for which is derived from the people, the powers of which are exercised by the representatives of the people, and the benefits of which are enjoyed by the people. This is a universal principle of mankind upon which this Constitution is founded. We reject and revoke all constitutions, laws, ordinances, and rescripts in conflict herewith.
\end{abstract}

We, the Japanese people, desire peace for all time and are deeply conscious of the high ideals controlling human relationship, and we have determined to preserve our security and existence, trusting in the justice and faith of the peace-loving peoples of the world. We desire to occupy an honored place in an international society striving for the preservation of peace, and the banishment of tyranny and slavery, oppression and intolerance for all time from the earth. We recognize that all peoples of the world have the right to live in peace, free from fear and want.

We believe that no nation is responsible to itself alone, but that laws of political morality are universal; and that obedience to such laws is incumbent upon all nations who would sustain their own sovereignty and justify their sovereign relationship with other nations.

\footnotetext{
${ }^{180}$ Parte da legislação trabalhista básica do Japão traduzida para o inglês pode ser encontrada em http://www.ilo.org/dyn/natlex/natlex browse.country?p lang=en\&p country=JPN e

http://www.loc.gov/law/help/guide/nations/japan.php

${ }^{181}$ Fonte: http://www.kantei.go.jp/foreign/constitution_and_government_of_japan/constitution_e.html
} 
We, the Japanese people, pledge our national honor to accomplish these high ideals and purposes with all our resources.

\section{CHAPTER I}

\section{THE EMPEROR}

Article 1. The Emperor shall be the symbol of the State and of the unity of the People, deriving his position from the will of the people with whom resides sovereign power.

Article 2. The Imperial Throne shall be dynastic and succeeded to in accordance with the Imperial House Law passed by the Diet.

Article 3. The advice and approval of the Cabinet shall be required for all acts of the Emperor in matters of state, and the Cabinet shall be responsible therefor.

Article 4. The Emperor shall perform only such acts in matters of state as are provided for in this Constitution and he shall not have powers related to government.

The Emperor may delegate the performance of his acts in matters of state as may be provided by law.

Article 5. When, in accordance with the Imperial House Law, a Regency is established, the Regent shall perform his acts in matters of state in the Emperor's name. In this case, paragraph one of the preceding article will be applicable.

Article 6. The Emperor shall appoint the Prime Minister as designated by the Diet.

The Emperor shall appoint the Chief Judge of the Supreme Court as designated by the Cabinet.

Article 7. The Emperor, with the advice and approval of the Cabinet, shall perform the following acts in matters of state on behalf of the people:

Promulgation of amendments of the constitution, laws, cabinet orders and treaties.

Convocation of the Diet.

Dissolution of the House of Representatives.

Proclamation of general election of members of the Diet.

Attestation of the appointment and dismissal of Ministers of State and other officials as provided for by law, and of full powers and credentials of Ambassadors and Ministers. Attestation of general and special amnesty, commutation of punishment, reprieve, and restoration of rights. 
Awarding of honors.

Attestation of instruments of ratification and other diplomatic documents as provided for by law.

Receiving foreign ambassadors and ministers.

Performance of ceremonial functions.

Article 8. No property can be given to, or received by, the Imperial House, nor can any gifts be made therefrom, without the authorization of the Diet.

\section{CHAPTER II}

\section{RENUNCIATION OF WAR}

Article 9. Aspiring sincerely to an international peace based on justice and order, the Japanese people forever renounce war as a sovereign right of the nation and the threat or use of force as means of settling international disputes.

In order to accomplish the aim of the preceding paragraph, land, sea, and air forces, as well as other war potential, will never be maintained. The right of belligerency of the state will not be recognized.

\section{CHAPTER III}

\section{RIGHTS AND DUTIES OF THE PEOPLE}

Article 10. The conditions necessary for being a Japanese national shall be determined by law.

Article 11. The people shall not be prevented from enjoying any of the fundamental human rights. These fundamental human rights guaranteed to the people by this Constitution shall be conferred upon the people of this and future generations as eternal and inviolate rights.

Article 12. The freedoms and rights guaranteed to the people by this Constitution shall be maintained by the constant endeavor of the people, who shall refrain from any abuse of these freedoms and rights and shall always be responsible for utilizing them for the public welfare.

Article 13. All of the people shall be respected as individuals. Their right to life, liberty, and the pursuit of happiness shall, to the extent that it does not interfere with the public welfare, be the supreme consideration in legislation and in other governmental affairs. 
Article 14. All of the people are equal under the law and there shall be no discrimination in political, economic or social relations because of race, creed, sex, social status or family origin.

Peers and peerage shall not be recognized.

No privilege shall accompany any award of honor, decoration or any distinction, nor shall any such award be valid beyond the lifetime of the individual who now holds or hereafter may receive it.

Article 15. The people have the inalienable right to choose their public officials and to dismiss them.

All public officials are servants of the whole community and not of any group thereof. Universal adult suffrage is guaranteed with regard to the election of public officials.

In all elections, secrecy of the ballot shall not be violated. A voter shall not be answerable, publicly or privately, for the choice he has made.

Article 16. Every person shall have the right of peaceful petition for the redress of damage, for the removal of public officials, for the enactment, repeal or amendment of laws, ordinances or regulations and for other matters; nor shall any person be in any way discriminated against for sponsoring such a petition.

Article 17. Every person may sue for redress as provided by law from the State or a public entity, in case he has suffered damage through illegal act of any public official.

Article 18. No person shall be held in bondage of any kind. Involuntary servitude, except as punishment for crime, is prohibited.

Article 19. Freedom of thought and conscience shall not be violated.

Article 20. Freedom of religion is guaranteed to all. No religious organization shall receive any privileges from the State, nor exercise any political authority.

No person shall be compelled to take part in any religious act, celebration, rite or practice. The State and its organs shall refrain from religious education or any other religious activity.

Article 21. Freedom of assembly and association as well as speech, press and all other forms of expression are guaranteed.

No censorship shall be maintained, nor shall the secrecy of any means of communication be violated.

Article 22. Every person shall have freedom to choose and change his residence and to choose his occupation to the extent that it does not interfere with the public welfare. 
Freedom of all persons to move to a foreign country and to divest themselves of their nationality shall be inviolate.

Article 23. Academic freedom is guaranteed.

Article 24. Marriage shall be based only on the mutual consent of both sexes and it shall be maintained through mutual cooperation with the equal rights of husband and wife as a basis. With regard to choice of spouse, property rights, inheritance, choice of domicile, divorce and other matters pertaining to marriage and the family, laws shall be enacted from the standpoint of individual dignity and the essential equality of the sexes.

Article 25. All people shall have the right to maintain the minimum standards of wholesome and cultured living.

In all spheres of life, the State shall use its endeavors for the promotion and extension of social welfare and security, and of public health.

Article 26. All people shall have the right to receive an equal education correspondent to their ability, as provided by law.

All people shall be obligated to have all boys and girls under their protection receive ordinary education as provided for by law. Such compulsory education shall be free.

Article 27. All people shall have the right and the obligation to work.

Standards for wages, hours, rest and other working conditions shall be fixed by law.

Children shall not be exploited.

Article 28. The right of workers to organize and to bargain and act collectively is guaranteed.

Article 29. The right to own or to hold property is inviolable.

Property rights shall be defined by law, in conformity with the public welfare.

Private property may be taken for public use upon just compensation therefor.

Article 30. The people shall be liable to taxation as provided by law.

Article 31. No person shall be deprived of life or liberty, nor shall any other criminal penalty be imposed, except according to procedure established by law.

Article 32. No person shall be denied the right of access to the courts. 
Article 33. No person shall be apprehended except upon warrant issued by a competent judicial officer which specifies the offense with which the person is charged, unless he is apprehended, the offense being committed.

Article 34. No person shall be arrested or detained without being at once informed of the charges against him or without the immediate privilege of counsel; nor shall he be detained without adequate cause; and upon demand of any person such cause must be immediately shown in open court in his presence and the presence of his counsel.

Article 35. The right of all persons to be secure in their homes, papers and effects against entries, searches and seizures shall not be impaired except upon warrant issued for adequate cause and particularly describing the place to be searched and things to be seized, or except as provided by Article 33.

Each search or seizure shall be made upon separate warrant issued by a competent judicial officer.

Article 36. The infliction of torture by any public officer and cruel punishments are absolutely forbidden.

Article 37. In all criminal cases the accused shall enjoy the right to a speedy and public trial by an impartial tribunal.

He shall be permitted full opportunity to examine all witnesses, and he shall have the right of compulsory process for obtaining witnesses on his behalf at public expense.

At all times the accused shall have the assistance of competent counsel who shall, if the accused is unable to secure the same by his own efforts, be assigned to his use by the State.

Article 38. No person shall be compelled to testify against himself.

Confession made under compulsion, torture or threat, or after prolonged arrest or detention shall not be admitted in evidence.

No person shall be convicted or punished in cases where the only proof against him is his own confession.

Article 39. No person shall be held criminally liable for an act which was lawful at the time it was committed, or of which he has been acquitted, nor shall he be placed in double jeopardy.

Article 40. Any person, in case he is acquitted after he has been arrested or detained, may sue the State for redress as provided by law.

\section{CHAPTER IV}




\section{THE DIET}

Article 41. The Diet shall be the highest organ of state power, and shall be the sole lawmaking organ of the State.

Article 42. The Diet shall consist of two Houses, namely the House of Representatives and the House of Councillors.

Article 43. Both Houses shall consist of elected members, representative of all the people. The number of the members of each House shall be fixed by law.

Article 44. The qualifications of members of both Houses and their electors shall be fixed by law. However, there shall be no discrimination because of race, creed, sex, social status, family origin, education, property or income.

Article 45. The term of office of members of the House of Representatives shall be four years. However, the term shall be terminated before the full term is up in case the House of Representatives is dissolved.

Article 46. The term of office of members of the House of Councillors shall be six years, and election for half the members shall take place every three years.

Article 47. Electoral districts, method of voting and other matters pertaining to the method of election of members of both Houses shall be fixed by law.

Article 48. No person shall be permitted to be a member of both Houses simultaneously.

Article 49. Members of both Houses shall receive appropriate annual payment from the national treasury in accordance with law.

Article 50. Except in cases provided by law, members of both Houses shall be exempt from apprehension while the Diet is in session, and any members apprehended before the opening of the session shall be freed during the term of the session upon demand of the House.

Article 51. Members of both Houses shall not be held liable outside the House for speeches, debates or votes cast inside the House.

Article 52. An ordinary session of the Diet shall be convoked once per year. 
Article 53. The Cabinet may determine to convoke extraordinary sessions of the Diet. When a quarter or more of the total members of either House makes the demand, the Cabinet must determine on such convocation.

Article 54. When the House of Representatives is dissolved, there must be a general election of members of the House of Representatives within forty (40) days from the date of dissolution, and the Diet must be convoked within thirty (30) days from the date of the election.

When the House of Representatives is dissolved, the House of Councillors is closed at the same time. However, the Cabinet may in time of national emergency convoke the House of Councillors in emergency session.

Measures taken at such session as mentioned in the proviso of the preceding paragraph shall be provisional and shall become null and void unless agreed to by the House of Representatives within a period of ten (10) days after the opening of the next session of the Diet.

Article 55. Each House shall judge disputes related to qualifications of its members. However, in order to deny a seat to any member, it is necessary to pass a resolution by a majority of two-thirds or more of the members present.

Article 56. Business cannot be transacted in either House unless one-third or more of total membership is present.

All matters shall be decided, in each House, by a majority of those present, except as elsewhere provided in the Constitution, and in case of a tie, the presiding officer shall decide the issue.

Article 57. Deliberation in each House shall be public. However, a secret meeting may be held where a majority of two-thirds or more of those members present passes a resolution therefor. Each House shall keep a record of proceedings. This record shall be published and given general circulation, excepting such parts of proceedings of secret session as may be deemed to require secrecy.

Upon demand of one-fifth or more of the members present, votes of the members on any matter shall be recorded in the minutes.

Article 58. Each House shall select its own president and other officials.

Each House shall establish its rules pertaining to meetings, proceedings and internal discipline, and may punish members for disorderly conduct. However, in order to expel a member, a majority of two-thirds or more of those members present must pass a resolution thereon. 
Article 59. A bill becomes a law on passage by both Houses, except as otherwise provided by the Constitution.

A bill which is passed by the House of Representatives, and upon which the House of Councillors makes a decision different from that of the House of Representatives, becomes a law when passed a second time by the House of Representatives by a majority of two-thirds or more of the members present.

The provision of the preceding paragraph does not preclude the House of Representatives from calling for the meeting of a joint committee of both Houses, provided for by law.

Failure by the House of Councillors to take final action within sixty (60) days after receipt of a bill passed by the House of Representatives, time in recess excepted, may be determined by the House of Representatives to constitute a rejection of the said bill by the House of Councillors.

Article 60. The budget must first be submitted to the House of Representatives. Upon consideration of the budget, when the House of Councillors makes a decision different from that of the House of Representatives, and when no agreement can be reached even through a joint committee of both Houses, provided for by law, or in the case of failure by the House of Councillors to take final action within thirty (30) days, the period of recess excluded, after the receipt of the budget passed by the House of Representatives, the decision of the House of Representatives shall be the decision of the Diet.

Article 61. The second paragraph of the preceding article applies also to the Diet approval required for the conclusion of treaties.

Article 62. Each House may conduct investigations in relation to government, and may demand the presence and testimony of witnesses, and the production of records.

Article 63. The Prime Minister and other Ministers of State may, at any time, appear in either House for the purpose of speaking on bills, regardless of whether they are members of the House or not. They must appear when their presence is required in order to give answers or explanations.

Article 64. The Diet shall set up an impeachment court from among the members of both Houses for the purpose of trying those judges against whom removal proceedings have been instituted.

Matters relating to impeachment shall be provided by law. 


\section{CHAPTER V}

\section{THE CABINET}

Article 65. Executive power shall be vested in the Cabinet.

Article 66. The Cabinet shall consist of the Prime Minister, who shall be its head, and other Ministers of State, as provided for by law.

The Prime Minister and other Ministers of State must be civilians.

The Cabinet, in the exercise of executive power, shall be collectively responsible to the Diet.

Article 67. The Prime Minister shall be designated from among the members of the Diet by a resolution of the Diet. This designation shall precede all other business.

If the House of Representatives and the House of Councillors disagree and if no agreement can be reached even through a joint committee of both Houses, provided for by law, or the House of Councillors fails to make designation within ten (10) days, exclusive of the period of recess, after the House of Representatives has made designation, the decision of the House of Representatives shall be the decision of the Diet.

Article 68. The Prime Minister shall appoint the Ministers of State. However, a majority of their number must be chosen from among the members of the Diet.

The Prime Minister may remove the Ministers of State as he chooses.

Article 69. If the House of Representatives passes a non-confidence resolution, or rejects a confidence resolution, the Cabinet shall resign en masse, unless the House of Representatives is dissolved within ten (10) days.

Article 70. When there is a vacancy in the post of Prime Minister, or upon the first convocation of the Diet after a general election of members of the House of Representatives, the Cabinet shall resign en masse.

Article 71. In the cases mentioned in the two preceding articles, the Cabinet shall continue its functions until the time when a new Prime Minister is appointed.

Article 72. The Prime Minister, representing the Cabinet, submits bills, reports on general national affairs and foreign relations to the Diet and exercises control and supervision over various administrative branches.

Article 73. The Cabinet, in addition to other general administrative functions, shall perform the following functions: 
Administer the law faithfully; conduct affairs of state.

Manage foreign affairs.

Conclude treaties. However, it shall obtain prior or, depending on circumstances, subsequent approval of the Diet.

Administer the civil service, in accordance with standards established by law.

Prepare the budget, and present it to the Diet.

Enact cabinet orders in order to execute the provisions of this Constitution and of the law.

However, it cannot include penal provisions in such cabinet orders unless authorized by such law.

Decide on general amnesty, special amnesty, commutation of punishment, reprieve, and restoration of rights.

Article 74. All laws and cabinet orders shall be signed by the competent Minister of State and countersigned by the Prime Minister.

Article 75. The Ministers of State, during their tenure of office, shall not be subject to legal action without the consent of the Prime Minister. However, the right to take that action is not impaired hereby.

\section{CHAPTER VI}

\section{JUDICIARY}

Article 76. The whole judicial power is vested in a Supreme Court and in such inferior courts as are established by law.

No extraordinary tribunal shall be established, nor shall any organ or agency of the Executive be given final judicial power.

All judges shall be independent in the exercise of their conscience and shall be bound only by this Constitution and the laws.

Article 77. The Supreme Court is vested with the rule-making power under which it determines the rules of procedure and of practice, and of matters relating to attorneys, the internal discipline of the courts and the administration of judicial affairs.

Public procurators shall be subject to the rule-making power of the Supreme Court.

The Supreme Court may delegate the power to make rules for inferior courts to such courts.

Article 78. Judges shall not be removed except by public impeachment unless judicially declared mentally or physically incompetent to perform official duties. No disciplinary action against judges shall be administered by any executive organ or agency. 
Article 79. The Supreme Court shall consist of a Chief Judge and such number of judges as may be determined by law; all such judges excepting the Chief Judge shall be appointed by the Cabinet.

The appointment of the judges of the Supreme Court shall be reviewed by the people at the first general election of members of the House of Representatives following their appointment, and shall be reviewed again at the first general election of members of the House of Representatives after a lapse of ten (10) years, and in the same manner thereafter. In cases mentioned in the foregoing paragraph, when the majority of the voters favors the dismissal of a judge, he shall be dismissed.

Matters pertaining to review shall be prescribed by law.

The judges of the Supreme Court shall be retired upon the attainment of the age as fixed by law.

All such judges shall receive, at regular stated intervals, adequate compensation which shall not be decreased during their terms of office.

Article 80. The judges of the inferior courts shall be appointed by the Cabinet from a list of persons nominated by the Supreme Court. All such judges shall hold office for a term of ten (10) years with privilege of reappointment, provided that they shall be retired upon the attainment of the age as fixed by law.

The judges of the inferior courts shall receive, at regular stated intervals, adequate compensation which shall not be decreased during their terms of office.

Article 81. The Supreme Court is the court of last resort with power to determine the constitutionality of any law, order, regulation or official act.

Article 82. Trials shall be conducted and judgment declared publicly.

Where a court unanimously determines publicity to be dangerous to public order or morals, a trial may be conducted privately, but trials of political offenses, offenses involving the press or cases wherein the rights of people as guaranteed in Chapter III of this Constitution are in question shall always be conducted publicly.

\section{CHAPTER VII}

\section{FINANCE}

Article 83. The power to administer national finances shall be exercised as the Diet shall determine. 
Article 84. No new taxes shall be imposed or existing ones modified except by law or under such conditions as law may prescribe.

Article 85. No money shall be expended, nor shall the State obligate itself, except as authorized by the Diet.

Article 86. The Cabinet shall prepare and submit to the Diet for its consideration and decision a budget for each fiscal year.

Article 87. In order to provide for unforeseen deficiencies in the budget, a reserve fund may be authorized by the Diet to be expended upon the responsibility of the Cabinet.

The Cabinet must get subsequent approval of the Diet for all payments from the reserve fund.

Article 88. All property of the Imperial Household shall belong to the State. All expenses of the Imperial Household shall be appropriated by the Diet in the budget.

Article 89. No public money or other property shall be expended or appropriated for the use, benefit or maintenance of any religious institution or association, or for any charitable, educational or benevolent enterprises not under the control of public authority.

Article 90. Final accounts of the expenditures and revenues of the State shall be audited annually by a Board of Audit and submitted by the Cabinet to the Diet, together with the statement of audit, during the fiscal year immediately following the period covered. The organization and competency of the Board of Audit shall be determined by law.

Article 91. At regular intervals and at least annually the Cabinet shall report to the Diet and the people on the state of national finances.

\section{CHAPTER VIII}

\section{LOCAL SELF-GOVERNMENT}

Article 92. Regulations concerning organization and operations of local public entities shall be fixed by law in accordance with the principle of local autonomy.

Article 93. The local public entities shall establish assemblies as their deliberative organs, in accordance with law.

The chief executive officers of all local public entities, the members of their assemblies, and 
such other local officials as may be determined by law shall be elected by direct popular vote within their several communities.

Article 94. Local public entities shall have the right to manage their property, affairs and administration and to enact their own regulations within law.

Article 95. A special law, applicable only to one local public entity, cannot be enacted by the Diet without the consent of the majority of the voters of the local public entity concerned, obtained in accordance with law.

\section{CHAPTER IX}

\section{AMENDMENTS}

Article 96. Amendments to this Constitution shall be initiated by the Diet, through a concurring vote of two-thirds or more of all the members of each House and shall thereupon be submitted to the people for ratification, which shall require the affirmative vote of a majority of all votes cast thereon, at a special referendum or at such election as the Diet shall specify.

Amendments when so ratified shall immediately be promulgated by the Emperor in the name of the people, as an integral part of this Constitution.

\section{CHAPTER X}

\section{SUPREME LAW}

Article 97. The fundamental human rights by this Constitution guaranteed to the people of Japan are fruits of the age-old struggle of man to be free; they have survived the many exacting tests for durability and are conferred upon this and future generations in trust, to be held for all time inviolate.

Article 98. This Constitution shall be the supreme law of the nation and no law, ordinance, imperial rescript or other act of government, or part thereof, contrary to the provisions hereof, shall have legal force or validity.

The treaties concluded by Japan and established laws of nations shall be faithfully observed.

Article 99. The Emperor or the Regent as well as Ministers of State, members of the Diet, judges, and all other public officials have the obligation to respect and uphold this Constitution. 


\section{CHAPTER XI}

\section{SUPPLEMENTARY PROVISIONS}

Article 100. This Constitution shall be enforced as from the day when the period of six months will have elapsed counting from the day of its promulgation.

The enactment of laws necessary for the enforcement of this Constitution, the election of members of the House of Councillors and the procedure for the convocation of the Diet and other preparatory procedures necessary for the enforcement of this Constitution may be executed before the day prescribed in the preceding paragraph.

Article 101. If the House of Councillors is not constituted before the effective date of this Constitution, the House of Representatives shall function as the Diet until such time as the House of Councillors shall be constituted.

Article 102. The term of office for half the members of the House of Councillors serving in the first term under this Constitution shall be three years. Members falling under this category shall be determined in accordance with law.

Article 103. The Ministers of State, members of the House of Representatives and judges in office on the effective date of this Constitution, and all other public officials who occupy positions corresponding to such positions as are recognized by this Constitution shall not forfeit their positions automatically on account of the enforcement of this Constitution unless otherwise specified by law. When, however, successors are elected or appointed under the provisions of this Constitution, they shall forfeit their positions as a matter of course. 
II) Lei de Assistência Pública do Japão (em inglês) ${ }^{182}$

Public Assistance Act

Act No. 144 of May 4, 1950

Chapter 1 General Provisions

(Purpose of This Act)

Article 1 The purpose of this Act is for the State to guarantee a minimum standard of living as well as to promote self-support for all citizens who are in living in poverty by providing the necessary public assistance according to the level of poverty, based on the principles prescribed in Article 25 of the Constitution of Japan.

(Nondiscrimination and Equality)

Article 2 All citizens may receive public assistance under this Act (hereinafter referred to as "public assistance") in a nondiscriminatory and equal manner as long as they satisfy the requirements prescribed by this Act.

(Minimum Standard of Living)

Article 3 The minimum standard of living guaranteed by this Act shall be where a person is able to maintain a wholesome and cultured standard of living.

(Supplementary Nature of Public Assistance)

Article 4 Public assistance shall be provided based on a requirement that a person who is living in poverty shall utilize his/her assets, abilities and every other thing available to him/her for maintaining a minimum standard of living.

(2) Any support given by a person responsible for support prescribed by the Civil Code (Act No. 89 of 1954) and any assistance prescribed by any other Act shall be provided in precedence to public assistance under this Act.

(3) The provisions of the preceding two paragraphs shall not preclude the provision of necessary public assistance in the case where there are urgent circumstances.

\footnotetext{
${ }^{182}$ Fonte: http://www.japaneselawtranslation.go.jp/law/detail/?id=24\&vm=04\&re=01 (acesso em 10/09/2013).
} 
(Interpretation and Operation of This Act)

Article 5 What is provided for in the preceding four Articles are fundamental principles of this Act based on which all interpretations and the operation of this Act shall be made.

(Definitions of Terms)

Article 6 The term "public assistance recipient" as used in this Act means a person who currently receives public assistance.

(2) The term "person requiring public assistance" is a person who requires public assistance regardless of whether he/she currently receives public assistance.

(3) The term "public assistance benefit" as used in

this Act means the money and/or goods furnished or lent as public assistance.

(4) The term "performance in money" as used in

this Act means to provide public assistance by furnishing or lending money.

(5) The term "performance in kind" as used in

this Act means to provide public assistance by furnishing or lending goods, furnishing medical care, providing services or any other means other than by providing performance in money.

Chapter 2 Principles of Public Assistance

Article 7 The provision of public assistance shall start based on an application filed by a person requiring public assistance, a person responsible for his/her support or any other relative living together; provided, however, that necessary public assistance may be provided without an application therefore when

a person requiring public assistance isunder urgent circumstances.

(Principle of Standard and Extent)

Article 8 Public assistance shall be provided, based on the level of the demand of a person requiring public assistance, which has been measured according to the standard specified by the Minister of Health, Labour and Welfare, to the extent that makes up the shortfall thereof that cannot be satisfied by the money or goods possessed by said person.

(2) The standard set forth in the preceding paragraph shall be one that sufficiently satisfies but shall not exceed the demand pertaining to a minimum standard of living, taking 
into consideration the age, sex,

household composition and location of the person requiring public assistance and any other necessary circumstances according to the type of public assistance.

(Principle of Conforming to Individual Needs)

Article 9 Public assistance shall be provided effectively and appropriately by taking into consideration the differences between the actual needs of individuals or households, such as the age, sex and health conditions of the person requiring assistance.

(Principle of Public Assistance on a Household Basis)

Article 10 The need for and extent of public assistance shall be determined on a household basis; provided, however, that, if this is difficult, such determination may be made on an individual basis.

Chapter 3 Types and Scope of Public Assistance

(Types)

Article 11 The type of public assistance shall be as follows:

(i) Livelihood assistance

(ii) Education assistance

(iii) Housing assistance

(iv) Medical assistance

(v) Long-term care assistance

(vi) Maternity assistance

(vii) Occupational assistance

(viii) Funeral assistance

(2) The assistance set forth in the items of the preceding paragraph shall be provided singly or in combination according to the needs of the person requiring public assistance.

(Livelihood Assistance) 
Article 12 Livelihood assistance shall be provided within the scope of the following matters to a person who is unable to maintain a minimum standard of living due to poverty:

(i) Clothing, food and any other things necessary for satisfying the demands of daily life

(ii) Transportation

(Education Assistance)

Article 13 Education assistance shall be provided within the scope of the following matters to a person who is unable to maintain a minimum standard of living due to poverty:

(i) Textbooks and other school supplies necessary in line with compulsory education

(ii) School-commuting supplies necessary in line with compulsory education

(iii) School meals and any other things necessary in line with compulsory education

(Housing Assistance)

Article 14 Housing assistance shall be provided within the scope of the following matters to a person who is unable to maintain a minimum standard of living due to poverty:

(i) Residence

(ii) Repairs and other things necessary for maintaining the housing

(Medical Assistance)

Article 15 Medical assistance shall be provided within the scope of the following matters to a person who is unable to maintain a minimum standard of living due to poverty:

(i) Medical examinations

(ii) Medicines or therapeutic materials

(iii) Medical treatment, surgery and any other therapy and treatment

(iv) In-home medical care management as well as care-taking and any other nursing pertaining to in-home medical care

(v) Admission to a hospital or clinic as well as care-taking and any other nursing pertaining to medical care in the hospital or clinic 
(vi) Transportation

(Long-Term Care Assistance)

Article 15-2 Long-term care assistance shall be provided within the scope of the matters listed in items (i) to (iv) and item (viii) to a person requiring long-term care (which means a person requiring long-term care prescribed in Article 7, paragraph (3) of the LongTerm Care Insurance Act [Act No. 123 of 1997]; the same shall apply in paragraph(3)) who is unable to maintain a minimum standard of living due to poverty, and shall be provided within the scope of the matters listed in items (v) to (viii) to a personrequiring support (which means a person requiring support prescribed in paragraph (4) of the same Article; the same shall apply in paragraph (6)) who is unable to maintain aminimum standard of living due to poverty:

(i) In-home care services (limited to those carried out based on an inhome care support plan)

(ii) Welfare equipment

(iii) Home renovation

(iv) Facility care services

(v) Care prevention services (limited to those carried out based on a care prevention support plan)

(vi) Welfare equipment for care prevention

(vii) Home renovation for care prevention

(viii) Transportation

(2) In-home care services prescribed in item (i) of the preceding paragraph means homevisit care services prescribed in Article 8, paragraph (2) of the Long-Term Care Insurance Act, home-visit bathing services prescribed in paragraph (3) of the same Article, home-visit nursing prescribed in paragraph (4) of the same Article, home-visit rehabilitation prescribed in paragraph (5) of the same Article, in-home medical care management counseling prescribed in paragraph (6) of the same Article, day care services prescribed in paragraph (7) of the same Article, day rehabilitation prescribed in paragraph (8) of the same Article, shortstay care services prescribed in paragraph (9) of the same Article, shortstay medical care prescribed in paragraph (10) of the same Article, care services provided in specified facilities prescribed in paragraph (11) of the same 
Article, lending of welfare equipment prescribed in paragraph (12) of the same Article, nighttime home-visit care services prescribed in paragraph (15) of the same Article, daycare services for the elderly with dementia prescribed in paragraph (16) of the same Article, small-scale and multifunctional in-home care services prescribed in paragraph(17) of the same Article, care services provided in group homes for the elderly with dementia prescribed in paragraph (18) of the same Article, and care services provided in community-based specified facilities prescribed in paragraph (19)

of the same Article, and any services equivalent thereto.

(3) An in-home care support plan prescribed in paragraph (1), item (i) means a plan which, for the purpose of allowing a person requiring long-term care who leads his/her life at home to use, etc. appropriately in-home care services and any other health and medical services and welfare services that are necessary for leading a daily life at home (hereinafter referred to as "in-home care services, etc." in this paragraph), specifies such matters as the types and contents of the in-home care services, etc. to be used by said person requiring long-term care.

\section{(4) Facility care services prescribed}

in paragraph (1), item (iv) means care services provided at community-based longterm care welfare facilities for the elderly prescribed in Article 8, paragraph (20) of the LongTerm Care Insurance Act, long-term care welfare facility services prescribed in paragraph (24) of the same Article, long-term care health facility services prescribed in paragraph (25) of the same Article and long-term care sanatorium facility services prescribed in paragraph (26) of the same Article.

(5) Care prevention services prescribed in paragraph (1), item (v) means homevisit care services for care prevention prescribed in Article 8-2, paragraph (2) of the LongTerm Care Insurance Act, home-visit bathing services for care prevention prescribed in paragraph (3) of the same Article, home-visit nursing for care prevention prescribed in paragraph (4) of the same Article, home-visit rehabilitation for care prevention prescribed in paragraph (5) of the same Article, in-home medical care management counseling for care prevention prescribed in paragraph (6) of the same Article, day care services for care prevention prescribed in paragraph (7) of the same Article, day rehabilitation forcare prevention prescribed in paragraph (8) of the same Article, shortstay care services for care prevention prescribed in paragraph (9) of the same Article, shortstay medical care for care prevention prescribed in paragraph (10) of the same Article, care services for care prevention provided in specified facilities prescribed in paragraph (11) of the same Article, lending of welfare equipment for care prevention prescribed in paragraph (12) of the same Article, day care services 
for the elderly with dementia for care prevention prescribed in paragraph (15) of the same Article, small-scale and multifunctional in-home care services for care prevention prescribed in paragraph (16) of the same Article, and care services for care prevention provided in group homes for the elderly with dementia prescribed in paragraph (17) of the same Article, and any services equivalent thereto.

(6) A care prevention support plan prescribed

in paragraph (1), item (v) means a plan which, for the purpose of allowing a person requiring support who leads his/her life at home to use, etc. appropriately care prevention services and any other health and medical services and welfare services that contribute to relieving or preventing from worsening the conditions where, due to physical or mental disabilities, said person requires constant care with regard to all or part of the basic activities of daily life such as bathing, excretion and eating or has trouble leading his/her daily life (hereinafter referred to as "care prevention services, etc." in this paragraph), specifies such matters as the types and contents of the care prevention services, etc. to be used by said person requiring long-term care, and which has been prepared by any person specified by anOrdinance of the Ministry of Health, Labour and Welfare set forth in Article 8-2, paragraph (18) from among the employees of a community comprehensive support center prescribed in Article 105-39, paragraph (1) of the Long-Term Care Insurance Act (referred to as a "community comprehensive support center" in Article 34-2, paragraph (2)and Article 542, paragraph (1)).

\section{(Maternity Assistance)}

Article 16 Maternity assistance shall be provided within the scope of the following matters to a person who is unable to maintain a minimum standard of living due to poverty:

(i) Assistance with delivery

(ii) Treatment prior to and after delivery

(iii) Absorbent cotton, gauze and other sanitary supplies

\section{(Occupational Assistance)}

Article 17 Occupational assistance shall be provided within the scope of the following matters to a person who is unable to or is likely to become unable to maintain a minimum standard of living due to poverty; provided, however, that this shall be limited 
to the case where such provision is likely to be able to

increase the income of saidperson or promote the self-support for said person:

(i) Funds, instruments or materials necessary for an occupation

(ii) Acquisition of skills necessary for an occupation

(iii) Things necessary for work

(Funeral Assistance)

Article 18 Funeral assistance shall be provided within the scope of the following matters to a person who is unable to maintain a minimum standard of living due to poverty:

(i) Postmortem examination

(ii) Transportation of the corpse

(iii) Cremation or burial

(iv) Cineration and any other things necessary for a funeral

(2) In any of the following cases, if there is a person who intends to conduct the funeral, funeral assistance set forth in the items of the preceding paragraph may be provided to said person:

(i) Where, in the case of the death of a public assistance recipient, there is no person responsible for his/her support who intends to conduct his/her funeral

(ii) Where, in the case of the absence of a person responsible for support who intends to conduct the funeral of a deceased, it is not possible to cover the expenses necessary for conducting the funeral with the money and goods left behind by the deceased

Chapter 4 (Organs for and Implementation of Public Assistance)

(Public Assistance Administrators)

Article 19 A prefectural governor, a city mayor, or a mayor of a town or village managing an office concerning welfare (hereinafter referred to as a "welfare office") prescribed in the Social Welfare Act (Act No. 45 of 1951) (a city mayor and such mayor of a town or village shall be collectively referred to as a "municipal mayor") shalldecide on and implement public assistance, pursuant to the provisions of this Act, for the following persons: 
(i) Any person requiring public assistance whose place of residence is within the jurisdictional

district of the welfare office under the management of the prefectural governoror municipal $m$ ayor

(ii) Any person requiring public assistance who does not have a place of residence or whose place of residence is unclear and whose current location is within the jurisdictional

district of the welfare office under the management of the prefectural governor or municipal $m$ ayor

(2) Even when the place of residence of a person requiring public assistance is clear, if said person is under urgent circumstances, public assistance for said person shall be provided

by the prefectural governor or the municipal mayor managing the welfare office having jurisdi ction over the current location of said person, notwithstanding the provisions of the preceding paragraph, until the urgent circumstances cease to exist.

(3) In the case of having a person requiring public assistance admitted into a relief facility, a rehabilitation facility or any other appropriate facility, or entrusting such admission to any such facility, or entrusting nursing care to the home of a private individual, or in the case of providing long-term care assistance (limited to facility care services) to a person requiring public assistance by entrusting it to a longterm care welfare facility for the elderly (which means a long-

term care welfare facility for the elderly prescribed in Article 8, paragraph (24) of the LongTerm Care Insurance Act; the same shall apply hereinafter) pursuant to the provisions of Article 34-2(2), the person who should providepublic assistance to said person while said admission or entrustment remains $v$ alid shall be decided based on the place of residence or the current location of said person prior tosaid admission or entrustment.

(4) The person who should provide public assistance pursuant to the provisions of the preceding three paragraphs (hereinafter referred to as the "public assistance administrator") may delegate all or a part of the affairs concerning decisions about and implementation of public assistance, but only to an administrative agency under his/her management.

(5) A public assistance administrator shall not be precluded from entrusting a part of the affairs concerning decisions about and implementation of public assistance to another public assistance administrator pursuant to the provisions of a Cabinet Order. 
(6) The mayor of a town or village without a welfare office (hereinafter referred to as the "mayor of a town or village") shall provide the necessary public assistance, as emergency treatment, to a person requiring public assistance within the district of that town or village who is in such a state that he/she cannot be left unattended due to particularly urgent circumstances.

(7) The mayor of a town or village shall carry out the following matters in order to ensure the appropriate execution of public assistance affairs conducted by the public assistance administrator or the head of the welfare office (hereinafter referred to as the "welfare office director"):

(i) On discovering a person requiring public assistance or discovering any change to the livelihood or any other circumstances of a public assistance recipient, the mayor of a town or village shall promptly inform the public assistance administrator or the welfare office director to that effect.

(ii) On receiving an application for the commencement of or a change to public assistance pursuant to the provisions of Article 24, paragraph (6), the mayor of a town orvillage shall send said application to the public assistance administrator.

(iii) On being requested

by the public assistance administrator or the welfare office director, the mayor of a town or village shall deliver a public assistance benefit to a public assistance recipient, etc.

(iv) On being requested

by the public assistance administrator or the welfare office director, the mayor of a town or village shall carry out an investigation concerning a person requiring public assistance.

(Delegation of Authority)

Article 20 A prefectural governor may delegate a part of his/her authority prescribed by this Act to an administrative agency under his/her management.

(Assisting Organ)

Article 21 A social welfare officer prescribed in the Social Welfare Act shall assist in the execution of the affairs of a prefectural governor or a municipal mayor with regard tothe enforcement of this Act.

(Cooperation of Welfare Commissioner) 
Article 22 A welfare commissioner prescribed in the Welfare Commissioners Act (Act No. 198 of 1948) shall assist in the execution of the affairs of a municipal mayor,

welfare office director or social welfare officer with regard to the enforcement of this Act.

(Audit of Affairs)

Article 23 The Minister of Health, Labour and Welfare shall have an official he/she has designated conduct an audit of the affairs concerning the enforcement of this Act carried out by a prefectural governor or municipal mayor, and a prefectural governor shall have an official he/she has designated conduct an audit of the affairs concerning the enforcement of this Act carried out by a municipal mayor.

(2) An official designated pursuant to the provisions of the preceding paragraph may make a request for the submission of materials or the provision of a statement of explanation that he/she finds necessary or give an instruction that he/she finds necessary to a prefectural governor or municipal mayor.

(3) The qualification of an official to be designated pursuant to the provisions of paragraph (1) shall be specified by a Cabinet Order.

(Commencement of or Change to Public Assistance Through Application)

Article 24 A public assistance administrator shall, where

an application for the commencement of public assistance has been filed, decide on the need for and the type,

extentand method of public assistance, and notify the applicant of the result in writing.

(2) The document under the preceding paragraph shall state the reason for the decision.

(3) The notice under paragraph (1) shall be given within fourteen days from the date on which an application has been filed; provided, however, that said period may be extended to thirty days in the case where there is any special reason, such as when an investigation on the state of the assets of persons responsible for support takes time, in which case, said reason shall be clearly indicated in the document under the same paragraph.

(4) When an applicant does not receive the notice under paragraph (1) within thirty days from the filing of an application for public assistance,

he/she may deem that the publicassistance administrator has dismissed the application. 
(5) The provisions of the preceding four paragraphs shall apply mutatis mutandis to the case where an application for a change to public assistance has been filed by a person prescribed in Article 7.

(6) An application for the commencement of or a change to public assistance may also be filed through the mayor of a town or village. In the case where the mayor of a town or village has received an application,

he/she shall send said the application to the public assistance administrator together with a document stating the presence or absence of any person responsible for support of the person requiring public assistance, the state of assets, and any other matters that would serve as a reference when making a decision concerning public assistance, within five days.

(Commencement of and Change to Public Assistance Ex Officio)

Article 25 A public assistance administrator shall, when a person requiring public assistance is under urgent circumstances, decide promptly on the ty pe, extent and method ofpublic assistance and commence public assistance ex officio.

(2) A public assistance administrator shall constantly investigate the status of the standard of living of a public assistance recipient, and when he/she finds a need for a change to the public assistance, he/she shall decide promptly on said change ex officio and notify the public assistance recipient of the result in writing. The provisions of paragraph (2) of the preceding Article shall apply mutatis mutandis to this case.

(3) The mayor of a town or village shall, when a person requiring public assistance is in such a state that he/she cannot be left unattended due to particularly urgentcircumstances, provide promptly the public assistance prescribed in Article 19, paragraph (6) ex officio.

(Suspension and Abolition of Public Assistance)

Article 26 A public assistance administrator shall, when a public assistance recipient no longer needs public assistance, decide promptly on the suspension or abolition of thepublic assistanc $e$, and notify the public assistance recipient of the result in writing. The same shall apply in the case of suspending or abolishing public assistance pursuant to the provisions of Article 28, paragraph (4) or Article 62, paragraph (3).

(Guidance and Instruction) 


\section{Article 27}

A public assistance administrator may give a public assistance recipient any guidance or instr uction that is necessary for maintaining or improving the recipient's standard of living or for achieving the purpose of public assistance.

(2) The guidance or instruction under the preceding paragraph shall respect the freedom of the public assistance recipient and be limited to the minimum extent necessary.

(3) The provisions of paragraph (1) shall not be interpreted as those that may force a public assistance recipient to receive guidance or instruction against his/her will.

\section{(Consultation and Advice)}

Article 27-2 A public assistance administrator may, when requested to do so by a person requiring public assistance, respond to a request for a consultation from the personrequiring public assistance and provide the necess ary advice, in order to promote self-support for the person requiring public assistance.

\section{(Investigation and Medical Examination)}

Article 28 When it is necessary for deciding on or implementing public assistance, a public assistance administrator may, in order to investigate the state of the assets, healthconditions or any other matters of a person requiring public assistance, have a relevant official enter the place of residence of said person requiring public assistance andinvestigate these matters or order said person requiring public assistance to have a medical examination from a doctor or a dentist designated by the public assistance administrator.

(2) A relevant official who conducts on-site investigations pursuant to the provisions of the preceding paragraph shall carry his/her identification and present it when requested to do so by a person concerned, pursuant to the provisions of an Ordinance of the Ministry of Health, Labour and Welfare.

(3) The authority for on-site inspections under the provisions of paragraph (1) shall not be interpreted as that granted for criminal investigation.

(4) A public assistance administrator may, when a person requiring public assistance has refused, obstructed or avoided an onsite investigation or has failed to follow an order to have a medical examination from a doctor or dentist under the provisions 
of paragraph (1), dismiss an application for the commencement of or a change to the publicassistance or may change, suspend or abolish the public assistance.

(Commissioning of Investigation and Request for Report)

Article 29 When it is necessary for deciding on or implementing public assistance, a public assistance administrator and a welfare office director may commission aninvestigatio $n$ to a public agency or request a report from a bank, trust company, the employer of a person requiring public assistance or a person responsible for support of the person requiring public assistance with regard to the assets and income of the person requiring public assistance or the person responsible for his/her support.

(Exclusion from Application of the Administrative Procedure Act)

Article 29-2 The provisions of Chapter 3 (excluding Articles 12 and 14) of the Administrative Procedure Act (Act No. 88 of 1993) shall not apply to any disposition under the provisions of this Chapter.

Chapter 5 Method of Public Assistance

(Method of Livelihood Assistance)

Article 30 Livelihood assistance shall be provided at the home of a public assistance recipient; provided, however, that, when this method cannot be used, when it is difficult to achieve the purpose of public assistance by this method, or when the public assistance recipient has so desired, public assistance may be provided by having the public assistance recipient admitted into a relief facility, a rehabilitation facility or any other appropriate facility, or entrusting such admission into any such facility, or entrusting nursing care to the home of a private individual.

(2) The provisions of the proviso to the preceding paragraph shall not be interpreted as those that are able to force admission into a facility or provision of nursing care against the will of a public assistance recipient.

(3) A public assistance administrator may, in the case where a person who has parental authority or is a guardian for a public assistance recipient fails to exercise his/her rights appropriately, take one of the measures under the proviso to paragraph (1) by obtaining the permission of a family court, even if said person objects to it. 
(4) The permission under the preceding paragraph shall be deemed to be a matter listed in Article 9, paragraph (1), Group A of the Domestic Affairs Adjustment Act (Act No. 152 of 1947) with regard to application of the same Act.

Article 31 Livelihood assistance shall be provided by way

of performance in money; provided, however, that when this method cannot be used, when it is not appropriate to use this method, or when it is necessary in order to achieve the purpose of public assistance, livelihood assistance may be provided by way of performance in kind.

(2) The public assistance benefit for livelihood assistance shall be provided in advance to the extent of one month's worth; provided, however, that when it is difficult to use thismethod, the public assistance benefit may be provided in advance in excess of one month's worth.

(3) The public assistance benefit in the case of providing livelihood assistance at home shall be calculated on a household basis and shall be delivered to the householder or a person equivalent thereto; provided, however, that if it is difficult to use this method, the public assistance benefit may be delivered to the public assistance recipient on an individual basis.

(4) In the case of providing livelihood assistance to a public assistance recipient who receives facility care services at a community-based longterm care welfare facility for the elderly (which means a community-based longterm care welfare facility for the elderly prescribed in Article 8, paragraph (20) of the LongTerm Care Insurance Act; the same shall apply hereinafter), a longterm care welfare facility for the elderly, or a long-term care health facility for the elderly (which means a long-term care health facility for the elderly prescribed in paragraph (25) of the same Article; the same shall apply hereinafter) that has been designated pursuant to the provisions of Article 54-2, paragraph (1) (including a community-based longterm care welfare facility for the elderly or a longterm care welfare facility for the elderly that is deemed to have received the designation under paragraph (1) of the same Article pursuant to the provisions of paragraph (2) of the same Article), if it is not appropriate to deliver the public assistance benefit to a person prescribed in the preceding paragraph or if it is necessary for achieving the purpose of public assistance, the public assistance benefit may be delivered to the head of said community-based long-term care welfare facility for the elderly or longterm care welfare facility for the elderly, or to the manager of said longterm care health facility forthe elderly, notwithstanding the provisions of paragraph (1) of the same Article. 
(5) The public assistance benefit in the case of providing livelihood assistance pursuant to the provisions of the proviso to paragraph (1) of the preceding Article shall be delivered to the public assistance recipient, the head of the facility, or the person to whom nursing care has been entrusted.

\section{(Method of Education Assistance)}

Article 32 Education assistance shall be provided by way of performance in money; provided, however, that when this method cannot be used, when it is not appropriate to use this method, or when it is necessary in order to achieve the purpose of public assistance, education assistance may be provided by way of performance in kind.

(2) The public assistance benefit for education assistance shall be delivered to the public assistance recipient, a person who has parental authority over the public assistance recipient or is a guardian of a public assistance recipient who is a minor, or the head of the school which the public assistance recipient attends.

(Method of Housing Assistance)

Article 33 Housing assistance shall be provided by way of performance in money; provided, however, that when this method cannot be used, when it is not appropriate to use this method, or when it is necessary in order to achieve the purpose of public assistance, housing assistance may be provided by way of performance in kind.

(2) Out of the housing assistance, residence as performance in kind shall be provided by having the public assistance recipient use a facility providing accommodation or byentrusting such actions to a facility providing accommodation.

(3) The provisions of Article 30, paragraph (2) shall apply mutatis mutandis to the case under the preceding paragraph.

(4) The public assistance benefit for housing assistance shall be delivered to the householder or a person equivalent thereto.

(Method of Medical Assistance)

Article 34 Medical assistance shall be provided by way of performance in kind; provided, however, that when this method cannot be used, when it is not appropriate to use this 
method, or when it is necessary in order to achieve the purpose of public assistance, medical assistance may be provided by way of performance in money.

(2) Out of the performance in kind prescribed in the preceding paragraph, medical care shall be furnished by having the public assistance recipient use a medical facility for persons requiring public assistance or by entrusting such actions to a medical facility for persons requiring public assistance or a medical institution that has been designated pursuant to the provisions of Article 49.

(3) Out of the furnishing of medical care prescribed in the preceding paragraph, the extent of the treatment that may be provided by a massage and finger pressure practitioner or a judo healing practitioner (hereinafter referred to as a "practitioner") pursuant to the provisions of the Act on Massage and Finger Pressure Practitioners, Acupuncturists, Moxibustion Practitioners, etc. (Act No. 217 of 1947) or the Judo Healing Practitioner Act (Act No. 19 of 1970) shall not be precluded from being furnished by way of entrusting said treatment to a practitioner who has been designated pursuant to the provisions of Article 49 as applied mutatis mutandis pursuant to the provisions of Article 55.

(4) In the case where there are urgent circumstances, a public assistance recipient may be furnished with medical care by a medical institution that has not been designated or be furnished with treatment by a practitioner who has not been designated, notwithstanding the provisions of the preceding two paragraphs.

(5) The public assistance benefit for medical assistance shall be delivered to the public assistance recipient.

(Method of Long-Term Care Assistance)

Article 34-2 Long-term care assistance shall be provided by way of performance in kind; provided, however, that when this method cannot be used, when it is not appropriate to use this method, or when it is necessary in order to achieve the purpose of public assistance, long-term care assistance may be provided by way of performance in money.

(2) Out of the performance in kind prescribed in the preceding paragraph, inhome care services, the furnishing of welfare equipment, facility care services, care preventionservices and the furnishing of welfare equipment for care prevention shall be provided by way of entrusting such assistance to a long-term care provider (which means a person who provides in-home care services as his/her business, a person who prepares in- 
home care support plans as his/her business, a person who sells specified welfare equipment prescribed in Article 8, paragraph (13) of the Long-Term Care Insurance Act as his/her business [referred to as a "specified welfare equipment dealer" in Article542, paragraph (1)], a community-based long-term care welfare facility for the elderly, a longterm care welfare facility for the elderly, a long-term care health facility for the elderly, a person who provides care prevention services as his/her business, a community comprehensive support center, or a person who sells specified welfare equipment for care prevention prescribed in Article 8-2, paragraph (13) of the same Act as his/her business [referred to as a "specified care prevention welfare equipment dealer" in Article 54-2, paragraph (1)]; the same shall apply hereinafter) who has been designated pursuant to the provisions of Article 54-2, paragraph (1) (including a community-based long-term care welfare facility for the elderly or a longterm care welfare facility for the elderly that is deemed to have received the designation under paragraph (1) of the same Article pursuant to the provisions of paragraph (2) of the same Article).

(3) The provisions of paragraphs (4) and (5) of the preceding Article shall apply mutatis mutandis to long-term care assistance. In this case, the term "urgent circumstances" inparagraph (4) of the same Article shall be deemed to be replaced with "urgent circumstances or other unavoidable circumstances."

(Method of Maternity Assistance)

Article 35 Maternity assistance shall be provided by way of performance in money; provided, however, that when this method cannot be used, when it is not appropriate to usethis method, or when it is necessary in order to achieve the purpose of public assistance, maternity assistance may be provided by way of performance in kind.

(2) Out of the performance in kind prescribed in the proviso to the preceding paragraph, the furnishing of midwifery shall be provided by way of entrusting such midwifery to a midwife who has been designated pursuant to the provisions of Article 49 as applied mutatis mutandis pursuant to the provisions of Article 55.

(3) The provisions of paragraphs (4) and (5) of Article 34 shall apply mutatis mutandis to maternity assistance.

(Method of Occupational Assistance) 
Article 36 Occupational assistance shall be provided by way of performance in money; provided, however, that when this method cannot be used, when it is not appropriate to use this method, or when it is necessary in order to achieve the purpose of public assistance, occupational assistance may be provided by way of performance in kind.

(2) Out of performance in kind prescribed in the proviso to the preceding paragraph, use of a facility necessary for the employment and provision of the skills necessary foroccupational assistance shall be provided by having the person requiring public assistance use a vocational facility or any other facility aimed at training, or by entrusting such assistance to such a facility.

(3) The public assistance benefit for occupational assistance shall be delivered to the public assistance recipient; provided however, that the public assistance benefit necessary for the use of a facility or the provision of skills may be delivered to the head of a vocational facility.

(Method of Funeral Assistance)

Article 37 Funeral assistance shall be provided by way of performance in money; provided, however, that when this method cannot be used, when it is not appropriate to use this method, or when it is necessary in order to achieve the purpose of public assistance, funeral assistance may be provided by way of performance in kind.

(2) The public assistance benefit for funeral assistance shall be delivered to the person conducting the funeral.

(Exception to the Method of Public Assistance)

Article 37-2 Out of the public assistance benefit delivered to the householder or a person equivalent thereto pursuant to the provisions of the main clause of Article 31, paragraph(3) or Article 33, paragraph (4), the public assistance benefit d elivered to the public assistance recipient pursuant to the provisions

of the proviso to Article 31, paragraph (3),Article 31, paragraph (5), Article 32, paragraph (2 ), Article 34, paragraph (5) (including the cases where it is applied mutatis mutandis pursuant to Article 34-

2, paragraph (3) orArticle 35, paragraph (3)) or Article 36, paragraph (3), or the public assist ance benefit delivered to the person conducting the funeral pursuant to the provisions of paragraph (2) of the preceding Article, a public assistance administrator may, when it is necessary for achieving the purpose of public assistance, pay the money equivalent to the amount ofthe $p$ 
remium for long-term care insurance (which means the premium prescribed

in Article 129, paragraph (1) of the Long-Term Care Insurance Act) and any other expenses to be paid by the public assistance recipient that is specified by a Cabinet Order to a person specified by a Cabinet Order in lieu of the public assistance recipient. In this case, when said payment has been made, it shall be deemed that the public assistance benefit has been delivered to the person to whom delivery should be made pursuant to these provisions.

Chapter 6 Public Assistance Facilities

(Types)

Article 38 The types of public assistance facilities shall be as follows:

(i) Relieffacility

(ii) Rehabilitation facility

(iii) Medical facility for persons requiring public assistance

(iv) Vocational facility

(v) Facility providing accommodation

(2) A relief facility shall be a facility aimed at providing livelihood assistance by admitting persons requiring public assistance who have difficulty leading their daily lives due to serious physical or mental disabilities.

(3) A rehabilitation facility shall be a facility aimed at providing livelihood assistance by admitting persons requiring public assistance who need nursing care and livelihood guidance due to physical or mental reasons.

(4) A medical facility for persons requiring public assistance shall be a facility aimed at furnishing medical care to persons requiring public assistance who need medical care.

(5) A vocational facility shall be a facility aimed at promoting the self-support for persons requiring public assistance whose ability to work is limited due to physical or mental reasons or due to household circumstances, by providing them with the necessary opportunities and assistance for employment or the acquisition of skills.

(6) A facility providing accommodation shall be a facility aimed at providing housing assistance to the households of persons requiring public assistance who have no home. 
(Standards of Public Assistance Facilities)

Article 39 The equipment and administration of a public assistance facility, the number of public assistance recipients using the public assistance facility, and the ratio betweensaid number and the total number of persons

using the public assistance facility shall clear the minimum standards specified by the Minister of Health, Labour and Welfare.

(Public Assistance Facilities of Prefectures, Municipalities and Local Incorporated Administrative Agencies)

Article 40 A prefecture may establish public assistance facilities.

(2) When a municipality or a local incorporated administrative agency (which means a local incorporated administrative agency prescribed in Article 2, paragraph (1) of the Local Incorporated Administrative Agency Act [Act No. 118 of 2003]; the same shall apply hereinafter) intends to establish a public assistance facility, it shall notify the prefectural governor of the matters specified by an Ordinance of the Ministry of Health, Labour and Welfare in advance.

(3) A prefecture, municipality or local incorporated administrative agency that has established a public assistance facility may abolish said public assistance facility or downsizeor suspend $t$ he operations of said public assistance facility as long as it does

not impede the public assistance for the currently admitted public assistance recipients.

(4) The establishment and abolition of a public assistance facility by a prefecture or municipality shall be prescribed by an ordinance.

(Establishment of Public Assistance Facilities of Social Welfare Juridical Persons and the Japanese Red Cross Society)

Article 41 A public assistance facility may only be established by a social welfare juridical person or the Japanese Red Cross Society, apart from a prefecture, municipality and local incorporated administrative agency.

(2) When a social welfare juridical person or the Japanese Red Cross Society intends to establish a public assistance facility, it shall submit a written application stating the following matters to the prefectural governor and obtain his/her approval in advance:

(i) The name and type of the public assistance facility 
(ii) The name of the juridical person, which is the establisher, as well as the name of the representative person, address and the state of assets of said juridical person

(iii) The articles of endowment, articles of incorporation and any other basic contracts

(iv) The size and structure of the building and any other equipment

(v) The user capacity

(vi) The scheduled date of the commencement of operations

(vii) The names and backgrounds of the person responsible for the management and executive officials to be engaged in the practical affairs of public assistance

(viii) The accounting policy

(3) In the case where an application for approval under the preceding paragraph has been filed, the prefectural governor shall grant approval if the facility complies with the following standards in addition to the standards prescribed in Article 39:

(i) The person who intends to establish the facility shall have a sound financial basis.

(ii) The establishment of the public assistance facility shall be necessary in light of the state of the distribution of persons

requiring public assistance in the area where saidpublic assistance facility will be mainly used.

(iii) The executive officials to be engaged in the practical affairs

of public assistance shall have the qualification specified by the Minister of Health, Labour and Welfare.

(4)When granting the approval under paragraph (1), the prefectural governor may limit the d uration of said public assistance facility or attach conditions that are found to be necessary for achieving the purpose of public assistance.

(5)When a social welfare juridical person or the Japanese Red Cross Society that has obtained the approval under paragraph (2) intends to change any of the matters listed in item (i) or items (iii) to (viii) of the same paragraph, it shall obtain the approval of the prefectural governor in advance. In the case where an application for said approval has been filed, the provisions of paragraph (3) shall apply mutatis mutandis. 
(Suspension of Operations or Abolition of Public Assistance Facilities of Social Welfare Juridical Persons or the Japanese Red Cross Society)

Article 42 When a social welfare juridical person or the Japanese Red Cross Society intends to suspend the operations of or abolish a public assistance facility, it shall obtain the approval of the prefectural governor in advance with regard to the time of the suspension or abolition, by clarifying the reasons therefor, the measures to be taken for thecurrently admitted public assistance recipients, and the method of disposing of property, and refunding the remainder of grants or subsidies that have been delivered pursuant to the provisions of Article 70, Article 72 or Article 74, if any.

\section{(Guidance)}

Article 43 A prefectural governor shall give the necessary guidance with regard to the administration of public assistance facilities.

(2) A municipal mayor shall assist in the guidance under the preceding paragraph given to a public assistance facility established by a social welfare juridical person or the Japanese Red Cross Society.

(Collection of Reports and On-Site Inspections)

Article 44 A prefectural governor may order the manager of a public assistance facility to report on the state of its operations or accounting or any other matters that are found to be necessary, or have a relevant official enter the facility, have him/her request the manager to allow the inspection of and provide a statement of explanation with regard to the equipment as well as accounting documents, medical records and any other books and documents (including electromagnetic records [which mean records prepared in an electronic form, magnetic form or any other form that cannot be recognized by human senses, and which are provided for use in information processing by computers] in thecase where electromagnetic records have been prepared or preserved in lieu of the preparation or preservation of such books and documents; the same shall apply in Article54, paragraph (1)), or have him/her carry out an inspection thereof.

(2) The provisions of Article 28, paragraphs (2) and (3) shall apply mutatis mutandis to an on-site inspection under the provisions of the preceding paragraph.

(Order for Improvement, etc.) 
Article 45 When any of the following grounds exist, the Minister of Health, Labour and Welfare may order a prefectural governor, and a prefectural governor may order a municipality or a local incorporated administrative agency to improve the equipment or administration of a public assistance facility or to abolish a public assistance facility:

(i) When the public assistance facility no longer conforms to the standards prescribed in Article 39

(ii) When the public assistance facility has lost the purpose of its existence

(iii) When the public assistance facility has violated this Act or any order based on this Act or any disposition based on this Act or such order

(2) When any of the following grounds exist, a prefectural governor may order a social welfare juridical person or the Japanese Red Cross Society

to improve the equipmentor administration of the public assistance facility or rescind the appr oval under Article 41, paragraph (2):

(i) When the public assistance facility falls under any of the items of the preceding paragraph

(ii) When the public assistance facility no longer conforms to the standards prescribed in the items of Article 41, paragraph (3)

(iii) When there has been a profit-making act with regard to the management of the public assistance facility

(iv) When operations have not been commenced

by the scheduled date under Article 41, paragraph (2), item (vi) (when approval for a change has been obtained pursuant to the provisions of paragraph (5)

of the same Article, the scheduled date for which said approval has been obtained) without justifiable grounds

(v) When the provisions of Article 41, paragraph (5) have been violated

(3) Notice under Article 15, paragraph (1) or Article 30 of the Administrative Procedure Act pertaining to a disposition under the provisions of the preceding paragraph shall begiven by fourteen days prior to the date of the hearing or the deadline of the submission of a written statement of explanation (in the case of granting an opportunity forexplanation by oral presentation, the date and time of the presentation). 
(4) When a prefectural governor has given notice under Article 15, paragraph (1) of the Administrative Procedure Act pertaining to rescission of the approval under the provisions of paragraph (2), he/she shall publicly notify the date and place of the hearing.

(5) Proceedings on the date of the hearing pertaining

to rescission of the approval under the provisions of paragraph (2) shall be conducted openly.

(Management Rules)

Article 46 The establisher of

a public assistance facility shall stipulate management rules clearly indicating the following matters, prior to the commencement of the operations:

(i) The purpose and policy of the operations

(ii) The fixed number, classification and contents of the duties of the officials

(iii) The method for treating persons using the facility

(iv) The rules to be observed by persons using the facility

(v) In the case of requiring the admitted persons to work, the type, method and hours of the work and a method for the appropriation of earnings from the work

(vi) Any other important matters concerning the management of the facility

(2) When a person other than a prefecture has

stipulated the management rules under the preceding paragraph, he/she shall promptly notify them to the prefectural governor. The same shall apply when such person intends to change the management rules that have been notified.

(3) When a prefectural governor finds that the contents of the management rules that have been notified pursuant to the provisions of the preceding paragraph are notappropriate for achieving the purpose of public assistance for persons using said facility, he/she may order changes to said management rules.

(Obligations of a Public Assistance Facility)

Article 47 When a public assistance facility has received an entrustment for the purpose of public assistance from a public assistance administrator, it may not refuse the entrustment without justifiable grounds. 
(2) A public assistance facility may

not give discriminatory or preferential treatment depending on race, beliefs,

social status or family status when admitting or treating a person requiring public assistance.

(3) A public assistance facility shall not force a person using the facility to participate in a religious act, celebration, ceremony or event.

(4) A public assistance facility shall not refuse an on-site inspection carried out by a relevant official pursuant to the provisions of Article 44.

(Head of a Public Assistance Facility)

Article 48 The head of a public assistance facility shall constantly endeavor to achieve an improvement in the standards of living and rehabilitation of persons using the facility.

(2)The head of a public assistance facility may provide necessary guidance to persons using the facility in accordance with the management rules.

(3)Aprefectural governor may restrain or prohibit the guidance under the preceding paragrap $h$ if he/she finds it necessary.

(4) When the head of a public assistance facility finds that there are grounds requiring a change to or suspension or discontinuance of public assistance with regard to a publicassistance recipient using the facility, he/she shall promptly notify this to the public assistance administrator.

Chapter 7 Medical Care Providers, Long-Term Care Providers and Midwifery Care Providers (Designation of Medical Care Providers)

Article 49 The Minister of Health, Labour and Welfare shall designate the providers in change of the medical care for medical assistance under this Act with regard to hospitals, clinics or pharmacies established by the State, by obtaining the consent of the competent minister, and a prefectural governor shall designate such providers with regard to any other hospitals, clinics (including institutions that are specified by a Cabinet Order as being equivalent to such hospitals or clinics), pharmacies, doctors or dentists, by obtaining the consent of the founder or the person himself/herself.

(Obligations of Designated Medical Care Providers) 
Article 50 A medical care provider who has been designated pursuant to the provisions of the preceding Article (hereinafter referred to as a "designated medical careprovider") shall provide medical care to public assistance recipients consideratel $y$ and meticulously, in accordance with the rules provided by the Minister of Health, Labour and Welfare.

(2) A designated medical care provider shall follow any guidance provided by a prefectural governor with regard to medical care for public assistance recipients.

(Notification of Change, etc.)

Article 50-2 A designated medical care provider shall, when there has been a change to the name of said designated medical care provider or any other matters specified by anOrdinance of the Ministry of Health, Labour and Welfare, or when having discontinued, suspended or resumed the operations of said designated medical care provider, notify the Minister of Health,

Labour and Welfare or prefectural governor who has made the designation under Article 49 to that effect within ten days, pursuant to the provisions of an Ordinance of the Ministry of Health, Labour and Welfare.

(Declination and Rescission of Designation)

Article 51 A designated medical care provider may decline the designation by giving advance notice of thirty days or more.

(2) When a designated medical care provider has violated the provisions of Article 50, the Minister of Health,

Labour and Welfare may rescind the designation in the casewhere the medical care provider has been designated by the Minister of Health, Labour and Welfare, and a prefectural governor may rescind the designation in the casewhere the medical care provider has been designated by the prefectural governor.

(Medical Treatment Policy and Medical Treatment Fees)

Article 52 The medical treatment policy and the medical treatment fees of a designated medical care provider shall be in accordance with the medical treatment policy and the medical treatment fees of the National Health Insurance.

(2) In the case where the medical treatment policy and the medical treatment fees prescribed in the preceding paragraph cannot be adopted or are considered inappropriate, themedical treatment policy and the medical trea 
tment fees shall be in accordance with the rules provided by the Minister of Health, Labour and Welfare.

(Examination and Payment of Medical Expenses)

Article 53 A prefectural governor may examine the contents of medical treatment provided by and the claims for medical treatment fees made by a designated medical care provider as needed and decide the amount of the medical treatment fees that the designated medical care provider may claim pursuant to the provisions of the preceding Article.

\section{(2) A designated}

medical care provider shall follow the decision under the preceding paragraph made by a prefectural governor.

(3) When a prefectural governor decides on the amount of medical treatment fees that a designated medical care provider may claim pursuant to the provisions of paragraph (1), he/she shall hear the opinion of an examination committee prescribed in the Act on the Social Insurance Medical Fee Payment Fund (Act No. 129 of 1948) or an examination organ related to medical care that has been specified by a Cabinet Order.

(4) A prefecture, city, or a town or village with a welfare office may entrust affairs concerning the payment of medical treatment fees to designated medical care providers tothe Social Insurance Medical Fee Payment Fund or a person specified by an Ordinance of the Ministry of Health, Labour and Welfare.

(5) No appeal under the Administrative Appeal Act (Act No. 160 of 1962) may be made with regard to a decision on the amount of the medical treatment fees under theprovisions of paragraph (1).

(Collection of Reports and On-Site Inspections)

Article 54 When there is a need to investigate whether or not the contents of medical treatment and the claims for medical treatment fees are appropriate, the Minister of Health, Labour and Welfare or a prefectural governor may order the manager of a designated medical care provider to report on any matters that are found to be necessary, or have the relevant official inspect the on-site the equipment, medical records and any other books and documents of said designated medical care provider.

(2) The provisions of Article 28, paragraphs (2) and (3) shall apply mutatis mutandis to an inspection under the provisions of the preceding paragraph. 
(Designation, etc. of Long-Term Care Providers)

Article 54-2 The Minister of Health, Labour and Welfare shall designate providers in charge of in-home care services, preparation of in-home care support plans, furnishing ofwelfare equipment, facility care services, care prevention services, preparation of care prev ention support plans, or furnishing of welfare equipment for care prevention forlongterm care assistance under this Act with regard to community-based longterm care welfare facilities for the elderly, long-term care welfare facilities for the elderly, orlong-term care health facilities for the elderly established by the State by obtaining the consent of the competent minister, and a prefectural governor shall designate such providers with regard to any other communitybased long-term care welfare facilities for the elderly, long-term care welfare facilities for the elderly or long-term care health facilities for the elderly, or persons who provide inhome care services as their business, persons who prepare in-home care support plans as their business, specified welfare equipment dealers, persons who provide care prevention services as their business, community comprehensive support centers or specified care prevention welfare equipmentdeal ers by obtaining the consent of the founder, the person himself/herself, or the establisher.

(2) When a designation under the main clause of Article 42-2, paragraph (1) of the LongTerm Care Insurance Act has been made with regard to a special nursing home for the elderly prescribed in Article 20-5 of the Old-Age Welfare Act (Act No. 133 of 1963), the communitybased long-term care welfare facility for the elderly shall be deemed to have received the designation under the provisions of the preceding paragraph at the time of said designation, and when a designation under Article 48, paragraph (1), item (i) of the same Act has been made, the long-term care welfare facility for the elderly shall be deemed to have received the designation under the provisions of the preceding paragraph at the time of said designation.

(3) A designation under paragraph (1) pertaining to a community-based longterm care welfare facility for the elderly that has been deemed to have received the designation under the same paragraph pursuant to the provisions of the preceding paragraph shall lose its effect with regard to said community-based longterm care welfare facility for the elderly when a designation under the main clause of Article 42-2, paragraph (1) of the Long-Term Care Insurance Act has been declined pursuant to the provisions of Article 78-7 of the same Act, when a designation under the main clause of Article 42-2, paragraph (1) of the same Act has been rescinded pursuant to the provisions of Article78-9 of the same Act, or when the effect of a designation under the main clause of Article 42-2, paragraph (1) of the same Act has been 
lost pursuant to the provisions of Article 70-2, paragraph (1) of the same Act as applied mutatis mutandis pursuant to Article 78-11

of the same Act, and a designation under paragraph (1) pertaining to a long-

term care welfare facility for the elderly that has been deemed to

have received the designation under the same paragraph pursuant to the provisions

of the precedingparagraph shall lose its effect with regard to said long-

term care welfare facility for the elderly when

a designation under Article 48, paragraph (1), item (i) of the same Act has been

declined pursuant to the provisions of Article 91 of the same Act, when

a designation under Article 48, paragraph (1), item ( $i$ ) of the same Act has been rescinded pursuant to the provisions of Article 92, paragraph (1) or Article 115-29, paragraph (6)

of the same Act, or when the effect of a designation under Article 48, paragraph (1),item ( $i$ )

of the same Act has been lost pursuant to the provisions of Article 86-2, paragraph (1)

of the same Act.

(4) The provisions of Article 50 to the preceding Article shall apply mutatis mutandis to a long-term care provider that has been designated pursuant to the provisions of paragraph (1) (including a community-based long-term care welfare facility for the elderly or a longterm care welfare facility for the elderly that is deemed to have received the designation under paragraph (1) pursuant to the provisions of paragraph (2)). In this case, the term "designated medical care provider" in Article 51, paragraph (1) shall be deemed to be replaced with "designated long-term care provider (excluding that pertaining to a community-based long-term care welfare facility for the elderly or a long-term care welfare facility for the elderly)," the phrase "an examination committee prescribed in the Act on the Social Insurance Medical Fee Payment Fund (Act No. 129 of 1948)or an examination organ related to medical care that has been specified by a Cabinet Order" in Article 53, paragraph (3) shall be deemed to be replaced with "an examination committee on long-term care assistance expenses prescribed by the Long-Term Care Insurance Act," and the phrase "the Social Insurance Medical Fee Payment Fund or a person specified by an Ordinance of the Ministry of Health, Labour and Welfare" in paragraph (4) of the same Article shall be deemed to be replaced with "a federation of national health insurance organizations" and any necessary technical replacement of terms concerning these provisions shall be specified by a Cabinet Order.

\section{(Application Mutatis Mutandis to Midwifery Care Providers)}

Article 55 The provisions of Articles 49 to 51 shall apply mutatis mutandis to a midwife in charge of midwifery for maternity assistance under this Act and to a massage and finger pressure practitioner or a judo healing practitioner 
in charge of treatment for the medical assistance under this Act, and the provisions of Articles 52 and 53 shall apply mutatis mutandis to a medical facility for persons

requiring public assistance.

(Public Notice)

Article 55-2 In any of the following cases, the Minister of Health, Labour and Welfare or a prefectural governor shall publicly notify to that effect:

(i) When a designation under Article 49 (including the cases where it is applied mutatis mutandis pursuant to the preceding Article; hereinafter the same shall apply in this Article) or Article 54-2, paragraph (1) has been made

(ii) When a notification under the provisions of Article 50-2 (including the cases where it is applied mutatis mutandis pursuant to Article 54-2, paragraph (4) or the preceding Article) has been given

(iii) When a designation under Article 49 has been declined pursuant to the provisions of Article 51, paragraph (1) (including the cases where it is applied mutatis mutandis pursuant to Article 54-2, paragraph (4) or the preceding Article)

(iv) When a designation under Article 49 has been rescinded pursuant to the provisions of Article 511, paragraph (2) (including the cases where it is applied mutatis mutandis pursuant to Article 54-2(4) or the preceding Article)

Chapter 8 Rights and Obligations of Public Assistance Recipients

(Prohibition of Adverse Changes)

Article 56 No public assistance recipient shall be subject to any adverse change to public assistance which has already been decided on, unless there are justifiable grounds.

(Prohibition of Public Imposts)

Article 57 No public assistance recipient shall have taxes or any other public imposts based on public assistance benefits imposed on him/her.

(Prohibition of Attachment)

Article 58 No public assistance recipient shall be subject to the attachment of already furnished public assistance benefit or the right to receive a public assistance benefit.

(Prohibition of Transfer) 
Article 59 A public assistance recipient may not transfer his/her right to receive public assistance.

\section{(Obligation in Daily Life)}

Article 60 A public assistance recipient shall constantly work diligently, make efforts to reduce his/her expenditure, and make other efforts to maintain and improve his/her standard of living.

\section{(Obligation of Notification)}

Article 61 A public assistance recipient shall, when there has been a change to his/her income, expenditure or any other condition related to his/her livelihood or when there has been a change to his/her place of residence or household composition, promptly notify the public assistance administrator or th e welfare office director to that effect.

(Obligation to Follow Instructions, etc.)

Article 62 When a public assistance administrator has decided to have a public assistance recipient admitted into a relief facility, a rehabilitation facility or any other appropriate facility, or entrust such admission to any such facility, or entrust nursing care to the home of a private individual, pursuant to the provisions of the proviso to article 30,paragraph (1), or when a public assistance administrator has given the necessary guidance or instruction to a public assistance recipient, pursuant to the provisions of Article27, the public assistance recipient shall follow such decision, guidance or instruction.

(2) A public assistance recipient using

a public assistance facility shall follow the management rules of said public assistance facility that have been established pursuant to the provisions of Article 46.

(3) When a public assistance recipient has violated any obligation under the provisions of the preceding two paragraphs, a public assistance administrator may change, suspendor discontinue the public assistance.

(4) In the case where a public assistance administrator gives a disposition to change, suspend or discontinue public assistance pursuant to the provisions of the preceding paragraph, he/she shall grant said public assistance recipient an opportunity for explanation. In this case, he/she shall notify the reason for said disposition and the date and place for giving the explanation, in advance. 
(5) The provisions of Chapter 3 (excluding Articles 12 and 14) of the Administrative Procedure Act shall not apply to a disposition under the provisions of paragraph (3).

\section{(Obligation to Refund Expenses)}

Article 63 When a public assistance recipient has received public assistance in an urgent case, etc. despite having a financial resource, he/she shall promptly refund the amount specified by the public assistance administrator within the scope of the amount equivalent to the public assistance benefit received.

Chapter 9 Appeal

\section{(Examining Agency)}

Article 64 In the case where a municipal mayor has delegated all or a part of the affairs concerning decisions on and the implementation of public assistance to an administrative agency under his/her management pursuant to the provisions of Article 19, paragraph (4), a request for examination of any disposition concerning said affairs shall be filed withthe prefectural governor.

\section{(Period for Determination)}

Article 65 When a request for examination of a disposition concerning a decision on or the implementation of public assistance has been filed, the Minister of Health, Labour and Welfare or a prefectural governor shall make a determination on said request for examination within fifty days.

(2) When no determination has been made within the period under the preceding paragraph, the person requesting the examination may deem that the Minister of Health, Labour and Welfare or the prefectural governor has dismissed the request for examination.

(Request for Re-examination)

Article 66 A person who is dissatisfied with the determination by the prefectural governor with regard to a request for examination of a disposition concerning a decision on or the implementation of public assistance that has been given by a municipal mayor or on a disposition given by an administrative agency under the management of a municipal mayor based 
on the delegation under the provisions of Article 19, paragraph (4) may file a request for reexamination with the Minister of Health, Labour and Welfare.

(2) The provisions of paragraph (1) of the preceding Article shall apply mutatis mutandis to the determination on a request for re-examination. In this case, the term "fifty days" in the same paragraph shall be deemed to be replaced with "seventy days."

\section{Article 67 Deletion}

\section{Article 68 Deletion}

\section{(Relationship Between Request for Examination and Litigation)}

Article 69 An action for rescission of a disposition given by a public assistance administrator based on the provisions of this Act may not be filed until after a determination has been made on a request for examination of said disposition.

\section{Chapter 10 Expenses}

(Payment by Municipalities)

Article 70 A municipality shall pay the following expenses:

(i) The following expenses concerning public assistance provided by the mayor pursuant to the provisions of Article 19, paragraph (1) (including public assistance provided by being entrusted pursuant to the provisions of paragraph (5) of the same Article):

(a) Expenses required for implementing public assistance (hereinafter referred to as "public assistance expenses")

(b) In the case of having a public assistance recipient admitted into a public assistance facility or entrusting such admission to a public assistance facility, or having a publicassistance recipient use a public assistance facility or entrusting such actions to a public assistance facility pursuant to the provisions of the proviso to Article 30, paragraph(1), Article 33, paragraph (2), or Article 36, paragraph (2), the office expenses of the public assistance facility that would be required in connection with such actions (hereinafter referred to as the "office expenses for a public assistance facility")

(c) In the case of having a public assistance recipient admitted into an appropriate facility, entrusting such admission to an appropriate facility, or entrusting nursing care to the home of a private individual pursuant to the provisions 
of the proviso to Article 30, paragraph (1), the office expenses that would be required in connection with such actions (hereinafter referred to as the "office expenses for entrustment")

(ii) Public assistance expenses, office expenses

for a public assistance facility, and office expenses

for entrustment concerning public assistance provided to a person whose place of residence is within the jurisdictional district of the welfare office under the management of the mayor, by a prefectural governor or another municipal mayor pursuant to the provisions

of Article 19, paragraph (2) (including public assistance provided by being entrusted pursuant to the provisions of paragraph (5) of the same Article)

(iii) Public assistance expenses, office expenses

for a public assistance facility, and office expenses

for entrustment concerning public assistance provided to a person whose place of residence is within the jurisdictional district of the welfare office under the management of the mayor, by another mayor of a town or village pursuant to the provisions of Article 19, paragraph (6)

(iv) Expenses required for the equipment

of public assistance facilities the municipality has established (hereinafter referred to as the "equipment expenses")

(v) Personnel expenses required in connection with the enforcement of this Act

(vi) Office expenses required in connection with the enforcement of this Act (hereinafter referred to as the "administrative office expenses")

(Payment by Prefectures)

Article 71 A municipality shall pay the following expenses:

(i) Public assistance expenses, office expenses

for a public assistance facility, and office expenses

for entrustment concerning public assistance provided by the governor pursuant to the provisions of Article 19, paragraph (1) (including public assistance provided by being entrusted pursuant to the provisions of paragraph (5) of the same Article)

(ii) Public assistance expenses, office expenses for a public assistance facility, and office expenses for entrustment concerning public assistance provided to a person whose place of residence is within the jurisdictional district of a welfare office under the management of the governor, by another prefectural governor or a municipal mayor pursuant to the provisions of Article 19, paragraph (2) (including public assistance provided by being entrusted pursuant to the provisions of paragraph (5) of the same Article) 
(iii) Public assistance expenses, office expenses

for a public assistance facility, and office expenses

for entrustment concerning public assistance provided to a person whose current location is within the jurisdictional

district of the welfare office under the management of the governor (excluding a person who has a place of residence outside said jurisdictional district), by a mayor of a town or village pursuant to the provisions of Article 19, paragraph (6)

(iv) Equipment expenses for public assistance facilities the prefecture has established

(v) Personnel expenses required in connection with the enforcement of this Act

(vi) Administrative office expenses required in connection with the enforcement of this Act

(Diversion of Funds)

Article 72 A prefecture, city, or a town or village with a welfare office shall, pursuant to the provisions of a Cabinet Order, temporarily divert funds to cover the public assistance expenses and office expenses for a public assistance facility to be paid by another prefecture or municipality to a public assistance recipient in a public assistance facility, designated medical care provider or a facility equivalent thereto, which is designated by the Minister of Health, Labour and Welfare, within the jurisdictional district ofthe welfare office under the management of the governor or mayor.

(2) A prefecture, city, or a town or village with a welfare office shall divert funds temporarily to cover the public assistance expenses, office expenses for a public assistance facility, and office expenses for entrustment concerning public assistance provided by the governor or mayor pursuant to the provisions of Article 19, paragraph (2) (including public assistance provided by being entrusted pursuant to the provisions of paragraph (5) of the same Article).

(3) A town or village shall divert funds temporarily to cover the public assistance expenses, office expenses for a public assistance facility, and office expenses for entrustment concerning public assistance provided by the mayor pursuant to the provisions of Article 19, paragraph (6)

(Expenses Borne by Prefectures)

Article 73 A prefecture shall bear the following expenses pursuant to the provisions of a Cabinet Order: 
(i) A quarter of the amount of the public assistance expenses, office expenses for a public assistance facility, and office expenses for entrustment paid by a municipality for a public assistance recipient who does not have a place of residence or whose place of residence is unclear

(ii) A quarter of the amount of the public assistance expenses, office expenses for a public assistance facility, and office expenses for entrustment paid for a public assistance recipient in a facility providing accommodation or a living support facility for single-mother families prescribed in Article 38 of the Child Welfare Act (Act No. 164 of 1947) (excluding a public assistance recipient who has had a place of residence outside the district of the municipality where said facility is located since prior to the start of his/heruse of said facility) by the municipality where said facility is located

\section{(Expenses Subsidized by a Prefecture)}

Article 74 In any of the following cases, a prefecture may subsidize up to three-quarters of the amount of the expenses required for the repair, renovation, expansion or maintenance of a public assistance facility established pursuant to the provisions of Article 41:

(i) When use of the public assistance facility proves to be extremely effective for public assistance of the public assistance recipient in the area

(ii) When no public assistance facility of the same type has been established by the prefecture or municipality in that area, or even if there has been, the facility has no spare capacity in terms of space or service

(2) Besides what is prescribed in Articles 43 to 45, supervision of a public assistance facility subsidized pursuant to the provisions of the preceding paragraph shall be in accordance with the following items:

(i) The Minister of Health,

Labour and Welfare may order the public assistance facility to report on the matters found to be necessary with regard to the state of its operations or accounting.

(ii) The Minister of Health, Labour and Welfare or a prefectural governor may, when he/she finds the budget of the public assistance facility to be inappropriate for achievingthe intended effect of public assistance, instruct that necessary changes should be made with regard to said budget.

(iii) The Minister of Health, Labour and Welfare or a prefectural governor may, when an employee of the public assistance facility has violated this Act, an order based on this 
Act, or a disposition based on this Act or such order, instruct that said employee should be removed.

\section{(Provisions Applied Mutatis Mutandis)}

Article 74-2 The provisions of Article 58, paragraphs (2) to (4) of the Social Welfare Act shall apply mutatis mutandis to a public assistance facility to which ordinary property has been transferred or lent pursuant to the provisions of Article 2, paragraph (2), item (i) of the Act on Special Measures Concerning National Property (Act No. 219 of 1952) or the provisions of Article 3, paragraph (1), item (iv) of the same Act and paragraph (2) of the same Article.

(Expenses Borne or Subsidized by the State)

Article 75 The State shall, pursuant to the provisions of a Cabinet Order, bear threequarters of the amount of the public assistance expenses, office expenses of a public assistance facility, and office expenses for entrustment paid by a municipality or prefecture.

(2) The State may, pursuant to the provisions of a Cabinet Order, subsidize up to two-thirds of the amount that a prefecture has subsidized to the establisher of a public assistance facility pursuant to the provisions of Article 74, paragraph (1).

(Disposal of Money and Goods Left Behind)

Article 76 In the case of providing funeral assistance pursuant to the provisions of Article 18, paragraph (2),

a public assistance administrator may allocate the money andsecurities left behind by the deceased to public assistance expenses, and if this is still not sufficient, he/she may allocate the proceeds from selling the goods left behind to public assistance expenses.

(2) A prefecture or municipality shall have a right of priority over the statutory liens of the other creditors for the goods left behind with regard to the expenses under the preceding paragraph.

\section{(Collection of Expenses)}

Article 77 When there is a person who must perform a duty of support for a public assistance recipient pursuant to the provisions of the Civil Code, the governor or mayor ofthe prefecture or municipality that has 
paid the public assistance expenses may collect all or a part of said expenses from said person within the scope of his/her duty.

(2) In the case under the preceding paragraph,

if the public assistance administrator and the person responsible for support fail to reach an agreement by a conference or are unable to hold a conference with regard to the amount to be borne by the person responsible for support, a family court shall decide on the amount following a motion by thepublic assistance administrator.

(3) A disposition under the preceding paragraph shall be deemed to be a matter listed in Article 9, paragraph (1), Group B of the Domestic Affairs Adjustment Act with regard to application of the same Act.

Article 78 When any person has received public assistance by filing a false application or by any other wrongful means or has had another person receive public assistance, thegovernor or mayor of the prefecture or municipal ity that has paid the public assistance expenses may collect all or a part of said expenses from said person.

(Order for Refund)

Article 79 In any of the following cases, the State or a prefecture may order the establisher of a public assistance facility to whom a subsidy or contribution has been delivered to refund all or a part of the already delivered subsidy or contribution:

(i) When the establisher has violated the conditions for delivery of a subsidy or contribution

(ii) When the establisher has received delivery of a subsidy or contribution by fraud or other wrongful means

(iii) When there has been a profit-making act with regard to the management of the public assistance facility

(iv) When the public assistance facility has violated this Act, an order based on this Act, or a disposition based on this Act or such order

(Exemption from Refund)

Article 80 In the case where all or a part of a public assistance benefit that has been provided in advance should be refunded in line with a change, suspension or discontinuance of public assistance, a public assistance administrator may, if he/she finds unavoidable circumstances applicable to a public assistance recipient who has 
consumed or lost the public assistance benefit, exempt said public assistance recipient from having to refund the public assistance benefit.

Chapter 11 Miscellaneous Provisions

(Request for Appointment of a Guardian)

Article 81 In the case where a public assistance recipient is a minor or an adult ward, if there is no person to perform the duty of a person who has parental authority or a guardian, a public assistance administrator shall promptly request a family court to appoint a guardian.

(Partial-Affairs Association, etc. of Towns and Villages)

Article 82 When towns or villages have established a welfare office by setting up a partialaffairs association or a wide area union, said partial-

affairs association or wide areaunion shall be deemed to be a town or village with a welfare office and the manger of said partial-affairs association or the head of said wide area union shall be deemed to be the mayor of a town or village managing a welfare office, with regard to application of this Act.

(Provisions on Transitional Measures in the Case Where the Public Assistance Administrator Has Changed)

Article 83 In the case where the public assistance administrator has changed due to the establishment or abolition of a welfare office of a town or municipality, any acceptance of an application for the commencement of or a change to public assistance or any decision on public assistance by the public assistance administrato $r$ prior to said changeshall be deemed to be an acceptance of an application or a decision by the public assistance administrator after said change; provide $d$, however, that it shall be deemed that no change has been made with regard to the payment or bearing of expenses concerning public assistance that has been provided or should have been provided prior to said change.

(Order for Implementation)

Article 84 Except for those that are delegated to a Cabinet

Order under this Act, the procedures for the implementation of this Act and any other necessary detailed regulations on the execution of this Act shall be specified by an Ordinance of the Ministry of Health, Labour and Welfare.

(Special Provisions for Large Cities, etc.) 
Article 84-2 In the case of a designated city under Article 252-19, paragraph (1) of the Local Autonomy Act (Act No. 67 of 1947) (hereinafter referred to as a "designated city") or a core city under Article 252-22, paragraph (1) of the same Act (hereinafter referred to as a "core city"), the affairs that are to be processed by a prefecture under this Act and which are specified by a Cabinet Order shall be processed by the designated city or core city (hereinafter referred to as the "designated city, etc."), pursuant to the provisions of a Cabinet Order. In this case, the provisions concerning a prefecture under this Act shall be deemed to apply to a designated city, etc. as provisions concerning a designated city, etc.

(2) The provisions of Article 66, paragraph (1) shall apply mutatis mutandis to an appeal pertaining to a disposition given by the mayor of a designated city, etc. pursuant to the provisions of the preceding paragraph.

(Special Provisions on Public Assistance Administrators)

Article 84-3 With regard to public assistance for a person admitted into a facility to support persons with disabilities prescribed in Article 5, paragraph (12) of the Act for Assisting in the Self-Support for Persons with Disabilities (Act No. 123 of 1942) pursuant to the provisions of Article 18, paragraph (2) of the Act on Welfare of Persons with Physical Disabilities (Act No. 283 of 1949) (hereinafter referred to as a "facility to support persons with disabilities" in this Article), a person admitted into a facility to support persons with disabilities pursuant to the provisions of Article 16, paragraph (1), item (ii) of the Act on Welfare of Persons with Mental Disabilities (Act No. 37 of 1960) or a facility established by the National Center for Persons with Severe Intellectual Disabilities, Nozominosono, pursuant to the provisions of Article 11, item (i) of the Act on the National Center for Persons with Severe Intellectual Disabilities, Nozominosono (Act No. 167 of 2002) (hereinafter referred to as "Nozominosono" in this Article), a person admitted into a nursing home for the elderly prescribed in Article 11, paragraph (1), item ( $i$ ) of the Old-Age Welfare Act or admitted into a special nursing home for the elderly prescribed in item (ii) of the same paragraph, a person admitted into a facility to support persons with disabilities, a Nozominosono, or a facility specified by an Ordinance of the Ministry of Health, Labour and Welfare under Article 5, paragraph (1) of the Act for Assisting in the Self-Support for Persons with Disabilities by receiving the provision of long-term care assistance expenses, etc. prescribed in Article 19, paragraph (1) of the same Act, pursuant to the provisions of Article 29, paragraph(1) or Article 30, paragraph (1) of the same Act, the provisions of Article 19, paragraph (3) shall apply while said person continues to be admitted 
in said facility, by deemed said person to be admitted pursuant to the provisions of the proviso to Article 30, paragraph (1).

\section{(Classification of Affairs)}

Article 84-4 The affairs that are to be processed by the local public entities listed in the left hand column of the appended table pursuant to the provisions listed respectively inthe right hand column of the same table shall be the Item (i) Statutory Entrusted Affairs prescribed in Article 2, paragraph (9), item (i) of the Local Autonomy Act.

(Delegation of Authority)

Article 84-5 The authority of the Minister of Health, Labour and Welfare prescribed in this Act may be delegated to the Director-General of a Regional Bureau of Health and Welfare pursuant to the provisions of an Ordinance of the Ministry of Health, Labour and Welfare.

(2) The authority delegated to the Director-General of a Regional Bureau of Health and Welfare pursuant to the provisions of the preceding paragraph may be delegated to the Director-General of a Regional Branch Bureau of Health and Welfare pursuant to the provisions of an Ordinance of the Ministry of Health, Labour and Welfare.

(Penal Provisions)

Article 85 A person who has received public assistance by filing a false application or by any other wrongful means or has had another person receive public assistance shall be punished by imprisonment with work for not more than three years or a fine of not more than 300,000 yen; provided, however, that the Penal Code shall apply when there are applicable provisions in the Penal Code (Act No. 45 of 1907).

Article 86 A person who has failed to make a report under the provisions of Article 44, paragraph (1), Article 54, paragraph (1) (including the cases where it is applied mutatis mutandis pursuant to Article 54-2, paragraph (4); hereinafter the same shall apply in this paragraph) or Article 74, paragraph (2), item (i) or has made a false report, or who has refused, obstructed or avoided an investigation or inspection by a relevant official under the provisions of Article 28, paragraph (1) (excluding the case of violation by theperson requiring public assistance), Article 44, paragra ph (2) or Article 54, paragraph (1) shall be punished by a fine of not more than 300,000 yen.

(2) When the representative person of a juridical person, or an agent, employee or any other worker of a juridical person or individual has committed an act in violation of the 
provisions of the preceding paragraph with regard to the operations of said juridical person or individual, not only the offender shall be punished but also said juridical person or individual shall be sentenced to the punishment under the preceding paragraph.

Supplementary Provisions (Extract)

\section{(Effective Date)}

(1) This Act shall come into force as from the day of promulgation and shall apply to assistance furnished on or after May 1, 1950.

(Repeal of the Public Assistance Act)

(2) The Public Assistance Act (Act No. 17 of 1946; hereinafter referred to as the "old Act") shall be repealed.

(Provisions on Transitional Measures)

(3) Any decision on public assistance made prior to the enforcement of this Act shall be deemed to have been made based on this Act.

(4) Any public assistance facility established by

a prefecture or any public assistance facility established by a municipality or non-profit corporation that has been approved pursuant to the provisions of Article 7 of the old Act, prior to the enforcement of this Act, shall be deemed to be a public assistance facility that has been established or approved based on this Act.

(6) Any medical facility designated by the Minister of Health and Welfare or any doctor, dentist, pharmacist, or midwife who has been designated by a municipal mayor pursuant to the provisions of Article 6 or Article 7 of the Ordinance for Enforcement of the Public Assistance Act (Imperial Ordinance No. 4.8 of 1946), prior to the enforcement of this Act, shall be deemed to be a medical care provider or midwife care provider designated by the Minister of Health and Welfare or a prefectural governor based on this Act.

(7) With regard to the application of penal provisions to acts in violation committed prior to the enforcement of this Act, the provisions then in force shall remain applicable.

(Provisions on Replacement of Terms)

(8) In the case where provisions of the old Act are cited in other laws or ordinances, if any of the provisions of this Act correspond to said provisions, they shall be deemed to be indicating the provisions of this Act that correspond to said provisions, except as otherwise provided by a Cabinet Order. 
(Loan Without Interest from the State, etc.)

(9) For the time being, the State may, within the scope of the budget, provide a loan without interest of an amount equivalent to the amount that the State may subsidize pursuant to the provisions of Article 75, paragraph (2) (in the case where any law or ordinance stipulates otherwise with regard to the proportion of subsidy by the State under these provisions, they shall include the provisions of said law or ordinance that stipulates otherwise; the same shall apply hereinafter) to a prefecture (in the casewhere the affairs under Article 74, paragraph (1), which are to be processed by a prefecture, are to be processed by a designated city, etc., pursuant to the provisions of Article 84-2, paragraph (1), this shall include said designated city, etc.; hereinafter the same shall apply in this paragraph and paragraphs (12) to (14) of the Supplementary Provisions) for the funds to be allocated to the expenses subsidized by said prefecture for the establisher of a public assistance facility other than said prefecture, with regard to a repair, renovation or expansion of a public assistance facility of which expenses may be subsidized by the State pursuant to the provisions of Article 75,paragraph (2) and which falls under Article 2, paragraph (1), item (ii) of the Act on Special Measures Concerning Promotion of Social Infrastructure Development Through Use of Proceeds from Sale of the Stock of Nippon Telegraph and Telephone Corporation (Act No. 86 of 1987).

(10) The period for reimbursement of the loan from the

State under the preceding paragraph shall be a period specified by a Cabinet Order not exceeding five years (including a grace period not exceeding two years).

(11) In addition to what is provided

for in the preceding paragraph, the method of reimbursement, advance reimbursement, and an $y$ other necessary matters concerning the reimbursement of the loan under the provisions of paragraph (9) of the Supplementary Provisions shall be specified by a Cabinet Order.

(12) When the State has provided a loan to a prefecture pursuant to the provisions of paragraph (9) of the Supplementary Provisions, it shall subsidize an amount equivalent to said loan under the provisions of Article 75, paragraph (2) with regard to the operations subject to said loan, and said subsidy shall be provided by way of delivering anamount equivalent to the reimbursement money for said loan at the time of the reimbursement of said loan.

(13) In the case where a prefecture has reimbursed the loan without interest which it has received pursuant to the provisions of paragraph (9) of the Supplementary Provisions ahead of the due date for reimbursement specified based on the provisions of paragraphs (10) and (11) of the Supplementary Provisions (excluding the cases specified by a Cabinet 
Order), said reimbursement shall be deemed to have been made on the arrival of the due date for reimbursement with regard to the application of the provisions of the preceding paragraph.

(14) The provisions of Article 79 shall apply mutatis mutandis to a loan without interest that is provided by the State to a prefecture pursuant to the provisions of paragraph(9) of the Supplementary Provisions. In this case, the phrase "a public assistance facility to which a subsidy or contribution has been delivered" in the same Article shall be deemed to be replaced with "a public assistance facility to which a loan has been provided," the phrase "delivered subsidy or contribution" in the same Article shall be deemed to be replaced with "provided loan," the phrase "conditions for the delivery of a subsidy or contribution" in item (i) of the same Article shall be deemed to be replaced with "conditions for the provision of a loan," and the phrase "delivery of a subsidy or contribution" in item (ii) of the same Article shall be deemed to be replaced with "provision of a loan."

Appended Table (Re: Article 84-4)

\begin{tabular}{|c|c|}
\hline $\begin{array}{l}\text { cture, } \\
\text { city, or } \\
\text { a } \\
\text { town or } \\
\text { village } \\
\text { with } \\
\text { a welfa } \\
\text { re offic } \\
\text { e }\end{array}$ & $\begin{array}{l}\text { Article 19, paragraphs (1) to (5), Article 24, paragraph (1) (including the cases where it is } \\
\text { applied mutatis mutandis pursuant to (5) } \\
\text { of the same Article), Article 25, paragraph (1) and paragraph (2), Article 26, Article 27, para } \\
\text { graph (1), Article 28, paragraph (1) andparagraph (4), Article 29, Articles } 30 \text { to 37-2 } \\
\text { (excluding Article 30, paragraph (2) and paragraph (4) and Article 33, paragraph (3)),Article } \\
\text { 47, paragraph (1), Article 48, paragraph (4), Article 53, paragraph (4) (including the cases } \\
\text { where it is applied mutatis mutandis pursuant to Article 54- } \\
\text { 2, paragraph (4) and Article 55), Article 61, Article 62, paragraph (3) and paragraph (4), Arti } \\
\text { cle 63,Article 76, paragraph (1), Article 77, paragraph (2), Article } 80 \text { and Article } 81\end{array}$ \\
\hline & $\begin{array}{l}\text { Article 23, paragraphs (1) and (2), Article 40, paragraph (2), Article 41, paragraphs (2) to } \\
\text { (5), Article 42, Article 43, paragraph (1),Article 44, paragraph (1), Article 45, Article 46, par } \\
\text { agraph (2) and paragraph (3), Article 48, paragraph (3), Article } 49 \text { (including the cases } \\
\text { where it is applied mutatis mutandis pursuant } \\
\text { to Article 55), Article 50, paragraph (2), Article 50- } \\
\text { 2, Article 51, paragraph (2), and Article 53, paragraph (1) and paragraph (3) (including the } \\
\text { cases where it is applied mutatis mutandis pursuant to Article 54- } \\
\text { 2,paragraph (4) and Article 55), Article 54, paragraph (1) (including the cases where it is } \\
\text { applied mutatis mutandis pursuant to Article54-2, paragraph }\end{array}$ \\
\hline A muni & $\begin{array}{l}\text { Article 43, paragraph (2), Article 77, paragraph (1), and Article } 78 \text { of } \\
\text { this Act, and Article 58, paragraphs (2) to (4) of the Social Welfare Act as applied mutatis }\end{array}$ \\
\hline
\end{tabular}




\begin{tabular}{|l|l|}
\hline cipality & mutandis pursuant to Article 74-2 of this Act \\
\hline A & \\
town or & \\
village & Article 19, paragraph (6) and paragraph (7), Article 24, paragraph (6), and Article 25, paragr \\
without & aph (3) \\
a welfa & \\
re & \\
office & \\
\hline
\end{tabular}


III) Lei de Assistência de Longo Prazo do Japão, artigos 1-13(em inglês). ${ }^{183}$

Long-Term Care Insurance Act

Act No. 123 of December 17, 1997

Chapter I General Provisions

(Purposes)

Article 1 The purposes of this Act are to improve health and medical care and to enhance the welfare of citizens. With regard to people who are under condition of need for long-term care due to disease, etc., as a result of physical or emotional changes caused by aging, and who require care such as for bathing, bodily waste elimination, meals,

etc., and require the functional training, nursing, management of medical treatment, and other medical care, these purposes are to be accomplished by establishing a longterm care insurance system based on the principle of the cooperation of citizens, solidarity, and determining necessary matters concerning related insurance benefits, etc., in order to provide benefits pertaining to necessary health and medical services and public aid services so that these people are able to maintain dignity and an independent daily life routine according to each person's own level of abilities.

(Long-Term Care Insurance)

Article 2 Long-Term Care Insurance shall provide necessary insurance benefits for a Condition of Need for Long-Term Care or for a Needed Support Condition of the insured person.

(2) Insurance benefits as set forth in the preceding paragraph shall be provided in order to contribute to reduction or prevention of aggravation of a Condition of Need for Long-Term Care or a Needed Support Condition, and shall be provided with careful attention to cooperation with medical care.

(3) Insurance benefits as set forth in paragraph (1) shall be provided in consideration of the appropriate health and medical services and public aid services that are offered by diverse providers and facilities comprehensively and effectively, according to the physical and mental conditions

${ }^{183}$ Fonte: http://www.japaneselawtranslation.go.jp/law/detail_main?id=94\&vm=4\&re= (acesso em 15/09/2013). 
of the insured person, said person's environment, etc., and based on the preferences of the insured person.

(4) With regard to the contents and level of insurance benefits as set forth in paragraph (1), it shall be considered that said person is able to live an independent daily life according to that person's own abilities in his or her home as much as possible, although said insured person becomes in a Condition of Need for Long-Term Care. (Insurers)

Article 3 Municipalities and special city wards shall provide Long-Term Care Insurance pursuant to the provisions of this Act.

(2)

Municipalities and special city wards shall establish a special account for income and expense $s$ regarding Long-Term Care Insurance pursuant to the provisions of Cabinet Orders.

(Citizen's Efforts and Obligations)

Article 4 A citizen shall be aware of his or her physical and mental changes due to aging and shall always strive to maintain and enhance good health in order to prevent becoming in a Condition of Need for Long-Term Care. In a case of becoming in a Condition of Need for Long-Term Care, a citizen shall strive to maintain and improve his or her existing abilities through the willing use of rehabilitation and other appropriate health andmedical services an d public aid services.

(2) Citizens shall be equally subjected to the expenses necessary for an Insured Long-Term Care Project, based on the principle of cooperation and solidarity.

(Responsibilities of the National and Prefectural Governments)

Article 5 The national government shall undertake measures to ensure the system of providing health and medical services and public aid services, and every other necessary action for the healthy and efficient operation of an Insured Long-Term Care Project. (2)

Prefectural governments shall provide necessary advice and appropriate support for the healt hy and efficient operation of an Insured Long-Term Care Project.

(Cooperation of Medical Insurers)

Article 6 Medical insurers shall cooperate for the healthy and efficient operation of an Insured Long-Term Care Project.

(Definitions) 


\section{Article 7 The term "Condition of Need for Long-Term Care" as used in}

this Act means a condition assumed to require care on a continual and steady basis for the whole or a part of basic movements in daily activities such as bathing, bodily waste elimination, meals, etc., due to physical or mental problems during the period specified by an Ordinance of the Ministry of Health, Labour, and Welfare, and said condition shall conforms to any of the categories stipulated by an Ordinance of the Ministry of Health, Labour, and Welfare according to the degree of needed care (herein referred to as a "Category of Condition of Need for Long-Term Care") (exceptwhen said condition is subject to a Needed Support Condition).

(2) The term "Needed Support Condition" as used in this Act means a condition assumed to require care on a continual and steady basis during the period specified by an Ordinance of the Ministry of Health, Labour, and Welfare that especially contributes to the reduction or prevention of the aggravation of the condition requiring care for the whole or a part of basic movements in daily activities such as bathing, bodily waste elimination, meals, etc., due to physical or mental problems, or a condition assumed to cause continual difficulties in performing daily activities due to physical or mental problems during the period specified by an Ordinance of the Ministry of Health, Labour, and Welfare, and said condition shall conforms to any category as stipulated by an Ordinance of the Ministry of Health, Labour, and Welfare according to the degree of needed support (herein referred to as "Category of Needed Support Condition").

(3) The term "Person Requiring Long-Term Care" as used in this Act means a person defined by any of the following items:

(i) a person that is in a Condition of Need for Long-Term Care and is the age of 65 or older;

(ii) a person that is in a Condition of Need for Long-Term Care and is the age of 40 to less than the age of 65, and the physical or mental problems that are the causes of said Condition of Need for Long-Term Care are a result of diseases that are caused by the physical or mental changes due to aging, specified by a Cabinet Order (herein referred to as "Specified Disease").

(4) The term "Person Requiring Support" as used in this Act means a person defined by any of the following items:

(i) a person that is in a Needed Support Condition and is the age of 65 or older;

(ii) a person that is in a Needed Support Condition and is the age of 40 to less than the age of 65, and the physical or mental problems that are the cause of said Needed Support Condition are caused by a Specified Disease.

(5) The term "Long-Term Care Support Specialist" as used in this Act means a person that provides consultation to a Person Requiring Long-Term Care or to a Person Requiring Support (herein referred to as a "Person Requiring Long-Term Care, etc.") and communicates with and coordinates Municipalities, a person performing InHome Services, a person performing Community-Based Service Business, a Facility Covered 
by Long-Term Care Insurance, a person performing Preventive Long-Term Care Service Business, a person performing Community-Based Preventive Long-Term Care, etc., in order for a Person Requiring Long-Term Care, etc., to be able to use appropriate In-Home Service, Community-Based Service, Facility Service, Preventive Long-Term Care Service, and Community-Based Service for Preventive Long-Term Care according to the mental and physical conditions, etc., of a Person Requiring Long-Term Care, etc., and who received Long-Term Care Support Specialist Certification as set forth in Article 69-7, paragraph (1) as a person possessing professional knowledge and skills regarding necessary support for a Person Requiring Long-Term Care, etc., to live an independent daily life.

(6) The term "Medical Insurance Acts" as used in this Act means the following acts:

(i) Health Insurance Act (Act No. 70 of 1992);

(ii) Seaman's Insurance Act (Act No. 73 of 1939);

(iii) National Health Insurance Act (Act No. 192 of 1958);

(iv) National Public Servants Mutual Aid Association Act (Act No. 128 of 1958);

(v) Local Public Service Mutual Aid Association Act (Act No. 152 of 1962);

(vi) Private School Personnel Mutual Aid Association Act (Act No. 245 of 1953).

(7) The term "Medical Insurers" as used in this Act means the national government, health insurance societies, municipalities (including special city wards), National Health Insurance Society, mutual aid associations, or Promotion and Mutual Aid Society for Private Schools of Japan that provide medical benefits pursuant to the provisions of Medical Insurance Acts.

(8) The term "Medical Insurance Subscriber" as used in this Act means the following persons:

(i) an insured person pursuant to the provisions of the Health Insurance Act, however, provided that it shall not apply to specially-insured day laborers pursuant to the provision of Article 3, paragraph (2) of the same Act;

(ii) an insured person pursuant to the provisions of the Seaman's Insurance Act;

(iii) an insured person pursuant to the provisions of the National Health Insurance Act;

(iv) a member of a mutual aid association pursuant to the National Public Servants Mutual Aid Association Law or the Local Public Care Service Mutual Aid Association Act;

(v) a subscriber to a Private School Personnel Mutual Aid System pursuant to the provisions of the Private School Personnel Mutual Aid Association Act;

(vi) an insured person's dependent pursuant to the provisions of the Health Insurance Act, Seaman's Insurance Act, National Public Servants Mutual Aid Association Law (including cases when applied mutatis mutandis pursuant to other Acts), or the Local Public Care Service Mutual Aid Association Act, however, provided that it shall not apply to a dependent pursuant to the provisions 
of Article 3, paragraph (2) of the Health Insurance Act of a speciallyinsured day laborer pursuant to the provisions of the same Act;

(vii) a person that received a specially-insured day laborer certificate book pursuant to the provisions of Article 126 of the Health Insurance Act and within a certain period until the term when all of the blank space for stamps for proof of health insurance of said certificate book are filled, and said dependent pursuant to the provisions of the same Act, however, provided that it shall not apply to a person that is within the period when said person is not a specially-insured day laborer pursuant to the proviso of Article 3, paragraph (2) of the same Act with the approval pursuant to the proviso of the same paragraph, and a person that has returned saidspeciallyinsured day laborer certificate book pursuant to the provisions of Article 126, paragraph (3) of the same Act, and said dependent pursuant to the provisions of the same Act.

Article 8 The term "In-Home Service" as used in this Act means Home-Visit Long-Term Care, Home-Visit Bathing Long-Term Care, Home-Visit Nursing, Home-Visit Rehabilitation, Guidance for Management of In-Home Medical Long-Term Care, Outpatient Day Long-Term Care, Outpatient Rehabilitation, Short-Term Admission for Daily Life Long-Term Care, ShortTerm Admission for Recuperation, Daily Life Long-Term Care Admitted to a Specified Facility, Rental Service of Equipment for Long-Term Care Covered by Public Aid, and Sale of Specified Equipment Covered by Public Aid. The term "In-Home Service Business" as used in this Act means business performing In-Home Service.

(2) The term "Home-Visit Long-Term Care" as used in this Act means care service that is for bathing, bodily waste elimination, meals, etc., and for other daily activities provided by long-term care public aid workers and other persons who determined by an Ordinance of the Ministry of Health, Labour, and Welfare (except for care services defined as Home-Visit at Night for Long-Term Care) and which are provided to a Person Requiring Long-Term Care at his or her home (herein referred to as "In-Home Person Requiring Long-Term Care")

(including a residence room at a moderate-fee home for the elderly as provided in Article 20-6 of the Public Aid for the Aged Act (Act No. 133 of 1963); a Fee-Based Home for the Elderly as prescribed in Article 29-1 of the same Act (referred to as a "Fee-Based Home for the Elderly" in paragraphs (11) and (19)); and other facilities as determined by an Ordinance of the Ministry of Health, Labour, and Welfare; the same shall apply hereinafter).

(3) The term "Home-Visit Bathing Long-Term Care" as used in this Act means care service that provides bathing service and a bathtub to a Person Requiring Long-Term Care by visiting his or her home.

(4) The term "Home-Visit Nursing" as used in this Act means medical care or assistance for necessary medical care provided to a Person Requiring Long-Term Care at his or her home (limited to those who are considered by an attending physician to be a person in the degree of need of medical treatment that conforms 
to standards as determined by an Ordinance of the Ministry of Health, Labour, and Welfare) by a nurse or other person as determined by an Ordinance of the Ministry of Health, Labour, and Welfare.

(5) The term "Home-Visit Rehabilitation" as used in this Act means physical therapy, occupational therapy, and other necessary rehabilitation that is provided to an In-Home Person Requiring Long-Term Care at his or her home (limited to those who are considered by an attending physician to be a person in the degree of need of medical treatment that conforms to standards as determined by an Ordinance of the Ministry of Health, Labour, and Welfare) in order to maintain and recover mental or physical functions and to assist with independently performing daily activities.

(6) The term "Guidance for Management of In-Home Medical Long-Term Care" as used in this Act means management and instructions for medical care and as determined by an Ordinance of the Ministry of Health, Labour, and Welfare.

Said management and instructions are provided to an In-Home Person Requiring Long-Term Care by a physician, dentist, pharmacist or other personnel as determined by an Ordinance of the Ministry of Health, Labour, and Welfare that are associated with a hospital, clinic, or pharmacy (herein referred to as "Hospital, etc.")

(7) The term "Outpatient Day Long-Term Care" as used in this Act means care that is for bathing, bodily waste elimination, meals, etc., and other care provided for daily activities and which is provided as defined by an Ordinance of the Ministry of Health, Labour, and Welfare, and functional training (except for care defined as Outpatient LongTerm Care for a Dementia Patient) by having an In-Home Person Requiring Long-Term Care commute to a facility as determined by an Ordinance of the Ministry of Health, Labour, and Welfare as set forth in Article 5-2, paragraph (3) of the Public Aid for the Aged Act or a Long-term care Day Service Center as provided in Article 20-2-2 of the same Act.

(8) The term "Outpatient Rehabilitation" as used in this Act means physical therapy, occupational therapy, and other necessary rehabilitation that is provided to an In-Home Person Requiring Long-Term Care (limited to those who are considered by an attending physician to be a person in the degree of need of medical treatment that conforms to standards as determined by an Ordinance of the Ministry of Health, Labour, and Welfare) by having said person commute to a Long-Term Care Health Facility, hospital, clinic, or other facility as determined by an Ordinance of the Ministry of Health, Labour, and Welfare and providing Outpatient Rehabilitation to said facility in order to maintain and recover his or her mental or physical functions and to assist independently performing daily activities.

(9) The term "Short-Term Admission for Daily Life Long-Term Care" as used in this Act means to provide care for bathing, bodily waste elimination, meals, 
etc., and other care for performing daily activities and to provide functional training for an In-Home Person Requiring Long-Term Care by having said person Short-Term Admission at a facility as determined by an Ordinance of the Ministry of Health, Labour, and Welfare as set forth in Article 5-2, paragraph (4) of the Public Aid for the Aged Act or at a Short-Term Admission Facility for the Elderly as provided in Article 20-3 of the same Act.

(10) The term "Short-Term Admission for Recuperation" as used in this Act means to provide nursing, long-term care and functional training under control of medical management, or other necessary medical treatment, or to provide care for performing daily activities to an In-Home Person Requiring Long-Term Care (limited to persons with the degree of necessity for medical treatment that conforms with standards as determined by an Ordinance of the Ministry of Health, Labour, and Welfare) by having said person ShortTerm Admission at a Long-Term Care Health Facility, Sanatorium Medical Facility for the Elderly Requiring Long-Term Care or other facility as determined by an Ordinance of the Ministry of Health, Labour, and Welfare.

(11) The term "Specified Facility" as used in this Act means a Fee-Based Home for the Elderly or other facility as determined by an Ordinance of the Ministry of Health, Labour, and Welfare that is not a Community-Based Specified Facility as provided in this Article, paragraph (19) of this Act. The term "Daily Life Long-Term Care Admitted to a Specified Facility" as used in this Act means care for bathing, bodily waste elimination, meals, etc., and other care for performing daily activities that is as determined by an Ordinance of the Ministry of Health, Labour, and Welfare, functional training, and medical care. Said care is provided to a Person Requiring Long-Term Care who is staying in a Specified Facility and is based on a plan which stipulates the content of services to be provided by said Specified Facility, the personnel in charge of the services, and otheritems as determined by an Ordinance of the Ministry of Health, Labour, and Welfare.

(12) The term "Rental Service of Equipment for Long-Term Care Covered by Public Aid" as used in this Act means the rental of equipment covered by public aid undertaken pursuant to provisions of a Cabinet Order of those types of equipment as determined by the Minister of Health, Labour, and Welfare among equipment covered by public aid for an In-Home Person Requiring Long-Term Care (equipment for the convenience of performing daily activities by a Person Requiring Long-Term Care, etc., whose physical or mental functions are underactive and that cause problems with performing daily activities, equipment to assist an Insured Person Requiring Long-Term Care, etc., independently performing daily activities and equipment for functional training or an Insured Person Requiring LongTerm Care, etc.,; the same shall apply in the following paragraph(13), and to the following Article, $\quad p$ aragraph (12) and paragraph (13) of this Act). 
(13) The term "Sale of Specified Equipment Covered by Public Aid" as used in this Act means the sale, undertaken pursuant to provisions of a Cabinet Order, of equipment covered by public aid among equipment provided for use in bathing or bodily waste elimination and other items provided by the Minister of Health, Labour, and Welfare (herein referred to as "Specified Equipment Covered by Public Aid") to an In-Home Person Requiring Long-Term Care.

(14) The term "Community-Based Service" as used in this Act means Home-Visit at Night for Long-Term Care, Outpatient Long-Term Care for a Dementia Patient, Multifunctional Long-Term Care in a Small Group Home, Communal Daily Long-Term Care for a Dementia Patient, Daily Life Long-Term Care for a Person Admitted to a Community-Based Specified Facility, and Admission to a Community-Based Facility for Preventive Daily Long-Term Care of the Elderly Covered by Public Aid. The term "Community-Based Service Business" as used in this Act means a business that provides Community-Based Service.

(15) The term "Home-Visit at Night for Long-Term Care" as used in this Act means care provided for bathing, bodily waste elimination, meals, etc., and for other daily activities that are as determined by an Ordinance of the Ministry of Health, Labour, and Welfare. Said care is provided to an In-Home Person Requiring Long-Term Care at his or her home by a long-term care public aid worker or other personnel specified by a Cabinet Order and as set forth in paragraph (2) of this Article, according to periodic night visits or as requested during the night.

(16) The term "Outpatient Long-Term Care for a Dementia Patient" as used in this Act means to provide care for bathing, bodily waste elimination, meals, etc., and for other daily activities as determined by an Ordinance of the Ministry of Health,

Labour, and Welfare, and functional training for an In-Home Person Requiring Long-Term Care who is in the condition that memory functions and other cognitive functions have becomeunderactive as far as causing disorder with performing daily activities due to organic changes of the brain that are caused by cerebral vascular disease,

Alzheimer's disease, or other factors (herein referred to as "Dementia"). This is accomplished by having said person commute to a facility as determined by an Ordinance of the Ministry of Health, Labour, and Welfare as set forth in Article 5-2, paragraph (3) of the Public Aid for the Aged Act or Long-Term Care Day Service Centers for the elderly as provided in Article 20-2-2 of the same Act.

(17) The term "Multifunctional Long-Term Care in a Small Group Home" as used in this Act means to provide care for bathing, bodily waste elimination, meals, etc., and for other daily activities as determined by an Ordinance of the Ministry of Health,

Labour, and Welfare, and functional training to an In-Home Person Requiring Long-Term Care at his or her home, or said bases of services as determined by an Ordinance of the Ministry of Health, Labour, and Welfare by having the person commute daily to 
a location or stay for short-term at said bases, according to the person's mental and physical condition, surroundings, etc., and based on his or her preference.

(18) The term "Communal Daily Long-Term Care for a Dementia Patient" as used in this Act means to provide care for bathing, bodily waste elimination, meals, etc., and for other daily activities, and functional training for a Person Requiring Long-Term Care who is suffering from Dementia (except for a person with the cause of Dementia being an acute disease), at a residence where the person lives communally.

(19) The term "Daily Life Long-Term Care for a Person Admitted to a Community-Based Specified Facility" as used in this Act means to provide care for bathing,

bodily waste elimination, meals, etc., and for other daily activities as determined by an Ordinance of the Ministry of Health,

Labour, and Welfare, functional training and medical care based on a plan that stipulates the content of services to be provided by said Community-Based Specified Facility, the personnel in charge of the services, and other items as determined by an Ordinance of the Ministry of Health, Labour, and Welfare. This service is provided to a Person Requiring Long-Term Care who is staying in a Fee-Based Home for the Elderly and other facilities as determined by an Ordinance of the Ministry of Health, Labour, and Welfare as set forth in paragraph (11) of this Article and for which the capacity of the fixed number of said residents is twenty-nine (29) or less (hereinafter referred to as "Community-Based Specified Facility"), among facilities for which residents are limited to a Person Requiring Long-Term Care, said person's spouse, and other personnel as determined by an Ordinance of the Ministry of Health, Labour, and Welfare (herein referred to as a "Specialized Long-Term Care Specified Facility").

(20) The term "Community-Based Facility for the Elderly Covered by Public Aid Requiring Long-Term Care" as used in this Act means an Intensive Care Home for the Elderly (limited to facilities for which the capacity of residents is twenty-nine (29) or less; the same shall apply hereinafter in this paragraph) provided in Article 20-5 of the Public Aid

for the Aged Act that aims to provide care for bathing, bodily waste elimination, meals, etc., and for other daily activities, functional training, health management, and medical care to a Person Requiring Long-Term Care who is staying in said Intensive Care Home for the Elderly based on a Community-Based Facility Service Plan (one that provides the content of services provided to a Person Requiring Long-Term Care who is staying in a CommunityBased Facility for the Elderly Covered by Public Aid Requiring Long-Term Care by said facility, the personnel in charge of said services, and other items as determined by an Ordinance of the Ministry of Health, Labour, and Welfare; the same shall apply hereinafter in this paragraph). The term "Admission to a Community-Based Facility for Preventive Daily Long-Term Care of the Elderly Covered by Public Aid" as used in 
this Act means to provide care for bathing, bodily waste elimination, meals, etc., and for other daily activities, functional training, health management, and medical care to a Person Requiring Long-Term Care who is staying in a Community-Based Facility for the Elderly Covered by Public Aid Requiring Long-Term Care, based on a Community-Based Facility Service Plan.

(21) The term "In-Home Long-Term Care Support" as used in this Act means to establish a plan (herein referred to as an "In-Home Service Plan" in this paragraph, Article 115-38, paragraph (1), item (v), and the appendedtable to this Act) that provides the types and contents of Designated In-Home Service, etc. (herein referred to as "Designated In-Home Service, etc." in this paragraph), the personnel in charge of said services to be used by an In-Home Person Requiring Long-Term Care, and other items as determined by an Ordinance of the Ministry of Health, Labour, and Welfare, at the request of said Person Requiring Long-Term Care and inconsideration of his or her mental and physical condition, surroundings, and the person's and his or her family's preferences, etc., in order for an InHome Person Requiring Long-Term Care to be able to use appropriately the Designated InHome Service as prescribed in Article 41, paragraph (1) of this Act, In-Home Service related to Exceptional Allowance for In-Home Long-Term Care Service or equivalent services, Designated Community-Based Service as prescribed in Article 42-2, paragraph (1) of this Act, Community-Based Service related to Exceptional Allowance for Community-Based Long-Term Care Service or equivalent services, and other necessary health and medical services or public aid services for performing daily activities at home (hereinafter referred to as "Designated In-Home Service, etc." in this paragraph); the term also means toprovide communication and coordination among Designated Providers of In-Home Long-Term Care as prescribed in Article 41, paragraph (1) of this Act, Designated Community-Based Service Provider as prescribed inArticle 422, paragraph (1) of this Act and other person and to provide other conveniences in order to ensure provision of the Designated In-Home Service, etc., based on said In-Home Service Plan, and in a case when said In-Home Person Requiring Long-Term Care requires admission to a Community-Based Facility for the Elderly Covered by Public Aid Requiring Long-Term Care or a Facility Providing Insured Long-Term Care, the term means to introduce a Community-Based Facility for the Elderly Covered by Public Aid Requiring Long-Term Care or Facility Providing Insured Long-Term Care and to provide other conveniences. The term "Designated In-Home Long-Term Care Support Business" as used in this Act means a business to provide In-Home Long-Term Care Support.

(22) The term "Facility Covered by Long-Term Care Insurance" as used in this Act means a Designated Facility Covered by Public Aid Providing Long-Term Care to the Elderly or a 
Long-Term Care Health Facility as prescribed in Article 48, paragraph (1), item (i) of this Act, and a Designated Medical Long-Term Care Sanatorium as prescribed in item (iii) of the same paragraph.

(23) The term "Facility Service" as used in this Act means a Facility Service for Long-Term Care Covered by Public Aid, Long-Term Care Health Facility Service, or Sanatorium LongTerm Care Service. The term "Facility Service Plan" as used in this Act means a plan for a Person Requiring Long-Term Care staying at a Designated Facility Covered by Public Aid Providing Long-Term Care to the Elderly, a Long-Term Care Health Facility, or a Sanatorium Medical Facility for the Elderly Requiring Long-Term Care that stipulates the content of services provided by said facilities, the personnel in charge of said services, and other items as determined by an Ordinance of the Ministry of Health, Labour, and Welfare.

(24) The term "Facility Covered by Public Aid Providing Long-Term Care to the Elderly" as used in this Act means an Intensive Care Home for the Elderly provided in Article 20-5 of the Public Aid for the Aged Act(limited to a facility with a capacity of thirty (30) residents or more; the same shall apply hereinafter in this paragraph).

The purpose of said facility is to provide care for bathing, bodily waste elimination, meals, etc., and for other

daily activities, functional training, health management, and medical care to a Person Requiring Long-Term Care who is staying in said Intensive Care Home for the Elderly based on a Facility Service Plan. The term "Facility Service for Long-Term Care Covered by Public Aid" as used in this Act means care that is provided based on a Facility Service Plan for bathing, bodily waste elimination, meals, etc., and for other daily activities, functional training, health management, and medical care to a Person Requiring Long-Term Care who is staying in said Facility Covered by Public Aid Providing Long-Term Care to the Elderly.

(25) The term "Long-Term Care Health Facility" as used in this Act means a facility which has obtained permission from the prefectural governor as set forth in Article 94, paragraph (1) of this Act as a facility with the purpose of providing nursing, care and functional training under control of medical management, and other necessary care for medical treatment and daily activities to a Person Requiring Long-Term Care (limited to persons whose degree of necessity for medical treatment conforms with standards as determined by an Ordinance of the Ministry of Health, Labour, and Welfare; the same shall apply hereinafter in this paragraph) based on a Facility Service Plan. The term "Long-Term Care Health Facility Service" as used in this Act means nursing, care and functional training under control of medical management, and other necessary care for medical treatment and daily activities 
for a Person Requiring Long-Term Care who is staying in a Long-Term Care Health Facility, based on a Facility Service Plan.

(26) The term "Sanatorium Medical Facility for the Elderly Requiring Long-Term Care as used in this Act means a facility such as a hospital or clinic that maintains a sanatorium ward or other beds ("Sanatorium Ward, etc.") that are specified by a Cabinet Order to provide appropriate nursing services according to the mental and physical characteristics of a Person Requiring Long-Term Care among Sanatorium Ward, etc., as prescribed in Article 7, paragraph (2) item (iv) of the Medical Care Act (Act No. 205, 1948), or beds which are specified by a Cabinet Order to provide appropriate nursing services according to the mental and physical characteristics of a Person Requiring Long-Term Care with Dementia among beds other than those for Long-Term Care Beds in the hospital; the same shall apply hereinafter), and with the purpose of providing medical care management, nursing, longterm care and other care under medical management, functional training, and other necessary medical care to a Person Requiring Long-Term Care who is in said bed for long-term care, etc., (limited to a person with the degree of need for medical treatment that conforms with standards as determined by an Ordinance of the Ministry of Health, Labour, and Welfare; the same shall apply hereinafter in this paragraph), based on a Facility Service Plan. The term "Sanatorium Long-Term Care Service" as used in this Act means medical care management, nursing, longterm care under medical management, and other care,functional training, and other necessary medical care provided to a Person Requiring Long-Term Care who is in a Sanatorium Ward, etc., for long-term care of a Sanatorium Medical Facility for the Elderly Requiring Long-Term Care based on a Facility Service Plan.

Article 8-2 The term "Preventive Long-Term Care Service" as used in this Act means HomeVisit Service for Preventive Long-Term Care, Home-Visit Bathing Service for Preventive Long-Term Care, Home-Visit Nursing Service for Preventive Long-Term Care, Home-Visit Rehabilitation Service for Preventive Long-Term Care, Management and Guidance for InHome Medical Service for Preventive Long-Term Care, other Outpatient Preventive LongTerm Care, Outpatient Rehabilitation for Preventive Long-Term Care, Short-Term Admission for Daily Preventive Long-Term Care, Short-Term Admission for Recuperation for Preventive Long-Term Care, Daily Preventive Long-Term Care Admitted to a Specified Facility, Rental of Specified Equipment for Preventive Long-Term Care Covered by Public Aid, and the Sale of Specified Equipment for Preventive Long-Term Care Covered by Public Aid. The term "Preventive Long-Term Care Service Business" as used in this Act means a business that provides Preventive Long-Term Care Service.

(2) The term "Home-Visit Service for Preventive Long-Term Care" as used in this Act means support for bathing, bodily waste elimination, meals, etc., and for other 
daily activities as determined by an Ordinance of the Ministry of Health, Labour, and Welfare. Said support is provided to a Person Requiring Support who receives support (herein referred to as a "Person Requiring In-Home Support"), at his or her home for the purpose of prevention of long-term care (reduction or prevention of deterioration of conditions for which a person requires continuous care for the whole or a part of basic movements during daily activities, such as bathing, bodily waste elimination, meals, etc., or a person that has difficulty performing daily activities due to physical or mental disabilities; the same shall apply herein) by a longterm care public aid worker or other personnel as provided by a Cabinet Order and for the period as determined by an Ordinance of the Ministry of Health, Labour, and Welfare.

(3) The term "Home-Visit Bathing Service for Preventive Long-Term Care" as used in this Act means bathing care provided to a Person Requiring In-Home Support with the purpose of preventing the long-term care ofsaid person by visiting said person at his or her home and providing a bathing tub for the period as determined by an Ordinance of the Ministry of Health, Labour, and Welfare.

(4) The term "Home-Visit Nursing Service for Preventive Long-Term Care" as used in this Act means medical care or assistance of a necessary medical care provided to a Person Requiring In-Home Support (limited to a person that is considered by an attending physician to be a person with the degree of need for medical treatment that conforms to standards as determined by an Ordinance of the Ministry of Health, Labour, and Welfare) at his or her home for the purpose of prevention of long-term care, and by a nurse or other personnel as determined by an Ordinance of the Ministry of Health,

Labour, and Welfare and for the period as determined by an Ordinance of the Ministry of Health, Labour, and Welfare.

(5) The term "Home-Visit Rehabilitation Service for Preventive Long-Term Care" as used in this Act means physical therapy, occupational therapy, and other necessary rehabilitation provided to a Person Requiring In-Home Support (limited to a person that is considered by an attending physician to be a person with the degree of need for medical treatment that conforms to standards as determined by an Ordinance of the Ministry of Health, Labour, and Welfare) at his or her home for the purpose of prevention of long-term care and for the period as determined by an Ordinance of the Ministry of Health, Labour, and Welfare.

(6) The term "Management and Guidance for In-Home Medical Service for Preventive LongTerm Care" as used in this Act means management and guidance for medical care that is stipulated by an Ordinance of the Ministry of Health,

Labour, and Welfare and said management and guidance for medical care is provided to a Person Requiring In-Home Support for the purpose of prevention of long-term care, and by a 
physician in a Hospital, etc., dentist, pharmacist, or other personnel as determined by an Ordinance of the Ministry of Health, Labour, and Welfare.

(7) The term "Outpatient Preventive Long-Term Care" as used in this Act means care for bathing, bodily waste elimination, meals, etc., and other support for daily activities as determined by an Ordinance of the Ministry of Health, Labour, and Welfare and performing functional training (except that which is defined as Preventive Long-Term Care for a Dementia Outpatient) that is provided to a Person Requiring In-Home Support for the purpose of prevention of long-term care by having said person commute to a facility as determined by an Ordinance of the Ministry of Health, Labour, and Welfare as set forth in Article 5-2, paragraph (3) of the Public Aid for the Aged Act, or a Long-Term Care Day Service Center as provided in Article 20-2-2 of the same Act, at said facility and for the period as determined by an Ordinance of the Ministry of Health, Labour, and Welfare.

(8) The term "Outpatient Rehabilitation for Preventive Long-Term Care" as used in this Act means physical therapy, occupational therapy, and other necessary rehabilitation provided to a Person Requiring In-Home Support (limited to a person that is considered by an attending physician to be a person with the degree of need for medical treatment that conforms to standards as determined by an Ordinance of the Ministry of Health, Labour, and Welfare) by having said person commute to a Long-Term Care Health Facility, hospital, clinic, or other facility as determined by an Ordinance of the Ministry of Health, Labour, and Welfare at said facility for the purpose of prevention of longterm care for the period as determined by an Ordinance of the Ministry of Health, Labour, and Welfare.

(9) The term "Short-Term Admission for Daily Preventive Long-Term Care" as used in this Act means to provide care for bathing, bodily waste elimination, meals, etc., support for other daily activities, and functional training to a Person Requiring In-Home Support by having said person stay for a short-term in a facility as determined by an Ordinance of the Ministry of Health, Labour, and Welfare as set forth in Article 52, paragraph(4) of the Public Aid for the Aged Act, or in a Short-Term Admission Facility for the Elderly as provided in Article 20-3 of the same Act, for the purpose of prevention of long-term care for the period as determined by an Ordinance of the Ministry of Health, Labour, and Welfare at said facility.

(10) The term "Short-Term Admission for Recuperation for Preventive Long-Term Care" as used in this Act means to provide nursing, long-term care, functional training and other necessary care for medical treatment under control of medical management, and support for daily activities to a Person Requiring In-Home Support (limited to a person with the degree of need for medical treatment that conforms with an Ordinance of the Ministry of Health, Labour, and Welfare) by having the person stay for a 
short-term in a Long-Term Care Health Facility, a Sanatorium Medical Facility for the Elderly Requiring Long-Term Care or other facility as determined by an Ordinance of the Ministry of Health, Labour, and Welfare for the purpose of prevention of longterm care for the period as determined by an Ordinance of the Ministry of Health, Labour, and Welfare at said facility.

(11) The term "Daily Preventive Long-Term Care Admitted to a Specified Facility" as used in this Act means care for bathing, bodily waste elimination, meals, etc., and support for other daily activities as determined by anOrdinance of the Ministry of Health,

Labour, and Welfare, functional training, and medical care that is provided to a Person Requiring Support who is staying in a Specified Facility (except for a Specialized Long-Term Care Specified Facility) for the purpose of prevention of long-term care, and based on a plan for providing services of specified content by said Specified

Facility, the personnel in charge of said services, and other items as determined by an Ordinance of the Ministry of Health, Labour, and Welfare.

(12) The term "Equipment Rental for Preventive Long-Term Care Covered by Public Aid" as used in this Act means a rental of equipment undertaken for a Person Requiring In-Home Support pursuant to the provisions of a Cabinet Order for equipment covered by public aid that is specified by the Minister of Health, Labour, and Welfare as equipment contributing to the prevention of long-term care to a Person Requiring In-Home Support among equipment covered by public aid.

(13) The term "Sale of Specified Equipment for Preventive Long-Term Care Covered by Public Aid" as used in this Act means sales undertaken for a Person Requiring In-Home Support pursuant to the provisions of a Cabinet Order of equipment covered by public aid that contributes to the prevention of long-term care that is provided for use in bathing or bodily waste elimination, as specified by the Ministry of Health, Labour, and Welfare, among equipment covered by public aid (herein referred to as "Specified Equipment for Preventive Long-Term Care Covered by Public Aid").

(14) The term "Community-Based Service for Preventive Long-Term Care" as used in this Act means Preventive Long-Term Care for a Dementia Outpatient, Multifunctional Preventive Long-Term Care in a Small Group Home, and Preventive Long-Term Care for a Dementia Patient in Communal Living. The term "Community-Based Preventive Long-Term Care Business" as used in this Act means a business that provides Community-Based Service for Preventive Long-Term Care.

(15) The term "Preventive Long-Term Care for a Dementia Outpatient" as used in this Act means to provide care for bathing, bodily waste elimination, meals, etc., and support for other daily activities as determined by an Ordinance of the Ministry of Health, Labour, and Welfare, and functional training to a Person Requiring In-Home Support who is suffering from Dementia, for the purpose of prevention of long-term care by having the 
person commute to a facility as determined by an Ordinance of the Ministry of Health, Labour, and Welfare as set forth in Article 5-2, paragraph (3) of the Public Aid for the Aged Act or a Long-Term Care Day Service Center as provided in Article 20-2-2 of the same Act, at said facility and for the period as determined by an Ordinance of the Ministry of Health, Labour, and Welfare.

(16) The term "Multifunctional Preventive Long-Term Care in a Small Group Home" as used in this Act means to provide care for bathing, bodily waste elimination, meals, etc., and support for other daily activities as determined by an Ordinance of the Ministry of Health, Labour, and Welfare, and functional training to a Person Requiring In-Home Support according to the mental and physical conditions of said person and according to the environment, etc., of said person based on the preferences of said person at his or her home or at a base of service as determined by an Ordinance of the Ministry of Health, Labour, and Welfare by having the person commute daily or stay for a shortterm for the purpose of prevention of long-term care.

(17) The term "Preventive Long-Term Care for a Dementia Patient in Communal Living" as used in this Act means to provide care for bathing, bodily waste elimination, meals, etc., support for other activities, and functional training to a Person Requiring Support (limited to a person that corresponds to a Category of Needed Support Condition as determined by an Ordinance of the Ministry of Health, Labour, and Welfare) who are suffering from Dementia (except for a person that cause of Dementia is an acute disease) at a residence where the person lives communally and for the purpose of prevention of longterm care.

(18) The term "Preventive Long-Term Care Support" as used in this Act means that a person as determined by an Ordinance of the Ministry of Health, Labour, and Welfare among the personnel of a community general support center as prescribed in Article 115-39, paragraph (1) of this Act, with regard to a Person Requiring InHome Support, considers said a Person's mental and physical condition, the present environment of saidPerson, the preferences, etc., of said Person Requiring In-Home Support and those of his or her family according to the request of said Person Requiring In-Home Support, and establishes a plan that stipulates the type and content of a Designated Provider of a Preventive Service to Long-Term Care Service, etc., that said Person will use, the personnel in charge of said services, and other items as determined by an Ordinance of the Ministry of Health, Labour, and Welfare (herein referred to as "Preventive Long-Term Care Service Plan" in this paragraph and the appended table) in order for the Person Requiring In-Home Support to be able to use appropriately those services as prescribed in Article 53, paragraph (1) of this Act that are of a Designated Preventive Long-Term Care Service, Preventive Long-Term Care Service pertaining to Exceptional Allowance for Preventive Service of Long-Term 
Care or services equivalent to said service, those services as prescribed in Article 542, paragraph (1) that are Designated Community-Based Preventive Service of Long-Term Care, Community-Based Service for Preventive Long-Term Care pertaining to Exceptional Allowance for Community-Based Preventive Service of Long-Term

Care, or equivalent services to said service, or other health andmedical services or public aid services contributing to prevention of long-term care (herein referred to as "Designated Preventive Long-Term Care Service, etc.") and that said personnel provide liaison and coordination among those who are a Designated Provider of a Preventive Service to LongTerm Care prescribed in Article 53, paragraph (1) of this Act, those who are a Designated Person Providing Community-Based Preventive Service of Long-Term Care as prescribed in Article 54-2, paragraph (1), and other personnel, and other convenience in order to ensure the provision of the Designated Preventive Long-Term Care Service, etc., based onsaid Preventive Long-Term Care Service Plan. The term "Preventive Long-Term Care Support Business" as used in this Act means a business that provides a Preventive Long-Term Care Support.

Chapter II Insured Persons

(Insured Person)

Article 9 A person that corresponds to any of the following items shall be an Insured Person of Long-Term Care for the Aged Insurance provided by a municipality or special city ward (herein referred to simply as "Municipality"):

(i) a person that is domiciled in the Municipality and is 65 years of age or more (herein referred to as "Primary Insured Person");

(ii) a person insured by medical insurance that is domiciled in the Municipality and is 40 years of age or more but less than 65 years of age (herein referred to as "Secondary Insured Person").

(Time of Acquisition of Qualifications)

Article 10 An Insured Person by Long-Term Care Insurance as provided by a Municipality pursuant to the provisions of the preceding Article shall acquire said eligibility on the date when said Person first corresponds to any of the following items:

(i) when a Medical Insurance Subscriber who is domiciled in said Municipality becomes 40 years of age;

(ii) when a Medical Insurance Subscriber who is 40 years of age or more but less than 65 years of age acquires domicile in said Municipality; 
(iii) when a person that is domiciled in said Municipality and is 40 years of age or more but less than 65 years of age becomes a Medical Insurance Subscriber;

(iv) when a person that is domiciled in said Municipality (other than a Medical Insurance Subscriber) becomes 65 years of age.

(Time of Loss of Qualification)

Article 11 An Insured Person by Long-Term Care Insurance provided by said Municipality pursuant to the provisions of Article 9 of this Act shall lose said qualification from the day following the date when said personfails to have domicile in said Municipality,

however, provided that said person shall lose this qualification on said date when the person $f$ ails to have domicile in said Municipality and obtains domicile in another Municipality on the same day.

(2) A Secondary Insured

Person shall lose this qualification on the date when said person becomes a non-Medical Insurance Subscriber.

(Notifications, etc.)

Article 12 A Primary Insured Person shall notify the Municipality of matters regarding acquisition and loss of qualification of Insured Person status and other necessary matters pursuant to the provisions of an Ordinance of the Ministry of Health, Labour, and Welfare, however, provided that this provision shall not apply to a case when the Primary Insured Person acquired the qualification of an Insured Person due to becoming subject to Article 10, item (iv) of this Act (except for a case pursuant to the provisions of an Ordinance of the Ministry of Health, Labour, and Welfare).

(2) The householder of said family in which a Primary Insured Person resides may provide the notification pursuant to the provisions of the preceding paragraph regarding said Primary Insured Person on behalf of a Primary Insured Person that resides in the household.

(3) An Insured Person may request the Municipality to issue a Certificate of Insured Person pertaining to said Insured Person.

(4) An Insured Person shall return the Certificate of Insured Person pursuant to the provisions of an Ordinance of the Ministry of Health, Labour, and Welfare when said Person no longer meets said qualifications. 
(5) When a notification is issued pursuant to the provisions of Articles 22 to 24, or Article 25 of the Basic Resident Registration Act (Act No. 81 of 1967) (limited to a case when a supplementary note is appended to the document pertaining to said notification pursuant to the provisions of Article 28-2 of the same Act), it shall be deemed as a notification pursuant to the main clause of paragraph (1) based on the same reason for said notification.

(6) In addition to the provisions as prescribed in each of the preceding paragraphs of this Article, necessary matters for notification pertaining to an Insured Person and that pertaining to the Certificate of Insured Person shall be as determined by an Ordinance of the Ministry of Health, Labour, and Welfare.

(Domicile Exception of an Insured Person that is Admitted to or has been a Resident of a Facility Subject to Domicile Exception)

Article 13 An Insured Person for whom it is determined that his or her domicile has changed to a location of one of the following facilities (herein referred to as "Facility Subject to Domicile Exception") and is located by admission or residence (herein referred to as "Admission, etc.") in said Facility Subject to Domicile Exception (an Insured Person for whom it is determined that his or her domicile has changed to a location where said Facility is located by moving into said Facility as listed in item (iii) is limited to a person for whom the admission measures are pursuant to the provisions of Article 11, paragraph (1), item (i) of the Public Aid for the Aged Act; hereinafter referred to as "Insured Person Subject to Domicile Exception" in this Article) and for whom it is determined to have had domicile in another Municipality (a Municipality other than the Municipality where said Facility Subject to Domicile Exception is located) at the time of moving in for Admission, etc., at said Facility Subject to Domicile Exception, shall be an Insured Person of Long-Term Care Insurance provided by said other Municipality of prior domicile, notwithstanding the provisions of Article 9;

however, provided that this provision shall not apply to an Insured Person Subject to Domicile Exception who moved in for Admission, etc., into two or more of a said Facility Subject to Domicile Exception, and said Person is determined to have moved consecutively from one said Facility Subject to Domicile Exception in which said Insured Person was admitted immediately prior to the said Facility Subject to Domicile Exception where said Insured Person is currently residing for Admission, etc. (herein referred to as the "Facility of First Prior Admission of an Insured Person" in this paragraph) into a Facility Subject to Domicile Exception in which said Insured Person is currently residing (herein referred to as the "Facility of Current Admission of an Insured Person" in this paragraph and the following paragraph) (collectively herein referred to as "Specified Continuous Admission of an Insured Person" in the following paragraph): 
(i) Facility Covered by Long-Term Care Insurance;

(ii) Specified Facility;

(iii) a Care Facility for the Elderly as provided in Article 20-4 of the Public Aid for the Aged Act.

(2) A person described in any of the following items that corresponds to the conditions of a Specified Continuous Admission of an Insured Person shall be an Insured Person of LongTerm Care Insurance of th eMunicipality as prescribed respectively in the following items, notwithstanding the provisions of Article 9:

(i) an Insured Person Subject to Domicile Exception for whom it is determined to have changed his or her domicile consecutively from one location where a Facility Subject to Domicile Exception is located to another such Facility by moving in for Admission, etc., at two or more of a Facility Subject to Domicile Exception, where in each said Facility the Insured Person moved in for Admission, etc., continuously, and is considered to have had domicile in another Municipality (a Municipality other than the Municipality where the Facility of Current Admission of an Insured Person is located) when said Insured Person moved in for Admission, etc., at said Facility of First Prior Admission of an Insured Person, from among two or more of a said Facility Subject to Domicile Exception, said other Municipality;

(ii) an Insured Person Subject to Domicile Exception for whom it is determined to have changed domicile from a location other than where one of a Facility Subject to Domicile Exception is located to a place where another said Facility Subject to Domicile Exception is located (herein referred to as "Change of Specified Domicile" in this item) by moving in for continuous Admission, etc., from one of two or more of a said Facility Subject to Domicile Exception where the Insured Person continues Admission, etc., to another said Facility Subject to Domicile Exception (herein referred to as "Continuous Admission, etc." in this item), and is considered to have had a domicile in another Municipality (a Municipality other than the Municipality where the Facility of Current Admission of an Insured Person is located) when moving in for Continuous Admission, etc., pertaining to a Change of Specified Domicile for the most recent occurrence, said other Municipality.

(3) A Facility Subject to Domicile Exception where an Insured Person Subject to Domicile Exception is in Admission, etc., shall provide the necessary cooperation to the Municipality where said Facility Subject to Domicile Exception is located and is the Municipality that provides Long-Term Care Insurance to said Insured Person Subject to Domicile Exception.

(...) 
IV) Convenção $n^{\circ} 102$ da OIT (1952) ${ }^{184}$

\section{$\underline{\text { Normas Mínimas da Seguridade Social }}$}

I - Aprovada na 35a reunião da Conferência Internacional do Trabalho (Genebra - 1952), entrou em vigor no plano internacional em 27.4.55.

II — Dados referentes ao Brasil:

a) aprovação = Decreto Legislativo n. 269, de 19.09.2008, do Congresso Nacional;

b) ratificação = 15 de junho de 2009;

A Conferência Geral da Organização Internacional do Trabalho, Convocada em Genebra pelo Conselho de Administração da Repartição Internacional do Trabalho, e reunida nessa cidade a 4 de junho de 1952, na sua trigésima quinta sessão;

Após ter decidido adotar diversas proposições relativas às normas mínimas para a seguridade social, questão que está compreendida no quinto ponto da ordem do dia da sessão;

Após ter decidido que essas proposições tomariam a forma de uma convenção internacional,

Adota, neste vigésimo oitavo dia de junho de mil novecentos e cinqüenta e dois, a seguinte convenção, que será denominada 'Convenção Concernente às Normas Mínimas para a Seguridade Social, 1952':

\section{PARTE I DISPOSIÇÕES GERAIS}

Art. $1^{\circ}-1$. Para os efeitos da presente convenção:

a) o termo 'determinado' significa prescrito por ou em virtude da legislação nacional;

b) o termo 'residência' significa a residência habitual no território do Membro, e o termo 'residente' significa uma pessoa que reside habitualmente no território do Membro;

c) o termo 'esposa' designa uma mulher que depende economicamente do marido;

d) o termo 'viúva' designa uma mulher que dependia economicamente de seu esposo no momento da morte do mesmo;

e) o termo 'criança' designa um menor abaixo da idade em que é obrigatória a frequiência à escola ou de menos de quinze anos, segundo o que for determinado;

f) o termo 'período de carência' significa seja um período de cotização seja de emprego ou de

\footnotetext{
${ }^{184}$ Fonte: http://www.oitbrasil.org.br/node/468
} 
residência, seja uma combinação qualquer desses períodos, segundo o que for determinado.

2. Para os fins dos artigos 10, 34 e 49, o termo 'prestações' se entende alusivo seja a serviços fornecidos diretamente, seja a prestações indiretas consistentes no reembolso das despesas a cargo do interessado.

Art. $2^{\circ}$ - Qualquer Membro para o qual a presente convenção estiver em vigor deverá:

a) aplicar:

I) a Parte I;

II) três ao menos das Partes II, III, IV, V, VI, VII, VIII, IX e X, compreendendo uma ao menos das Partes IV, V, VI, IX e X;

III) as correspondentes disposições das Partes XI, XII e XIII;

IV) a Parte XIV;

b) especificar na ratificação quais dentre as Partes II a X cujas obrigações decorrentes da convenção aceita.

Art. $3^{\circ}-1$. Um Membro cuja economia e recursos médicos não tenham atingido um desenvolvimento suficiente pode, se a autoridade competente o desejar e pelo espaço de tempo que ela julgar necessário, beneficiar-se, mediante uma declaração anexa à sua ratificação, das derrogações temporárias que constam dos artigos seguintes: 9d; 12(2); 15d; 18(2); 21c; 27d; 33b; 34(3); 41d; 48c; 55d e 61d.

2. Todo Membro que tenha feito uma declaração nos termos do parágrafo 1 do presente artigo deve, no relatório anual sobre a aplicação da presente convenção, que é obrigado a apresentar de acordo com o artigo 22 do Estatuto da Organização Internacional do Trabalho, declarar a propósito de cada uma das derrogações das quais se beneficiou:

a) se as razões que o levaram a fazê-lo perduram; ou

b) se, a partir de uma data determinada, renuncia a se prevalecer da derrogação em apreço.

Art. $4^{\circ}-1$. O Membro que ratificar a presente convenção pode, posteriormente, notificar o Diretor-Geral da Repartição Internacional do Trabalho de que aceita as obrigações decorrentes da convenção no que diz respeito a uma ou várias das Partes II a X que ainda não tenham sido especificadas na sua ratificação.

2. Os compromissos previstos no parágrafo 1 do presente artigo serão considerados como parte integrante da ratificação e produzirão efeitos idênticos a partir da data de sua notificação.

Art. $5^{\circ}$ - Quando, em consequiência da aplicação de qualquer das Partes II a X da presente 
convenção, objeto de sua ratificação, um Membro for obrigado a amparar determinadas categorias de pessoas, perfazendo ao menos uma certa percentagem de assalariados ou residentes, deverá, antes de se comprometer a aplicar a Parte em questão, certificar-se de que a referida percentagem será atingida.

Art. $6^{\circ}$ - Tratando-se da aplicação das Partes II, III, IV, V, VIII (no que diz respeito a serviços médicos), IX ou X da presente convenção, um Membro pode levar em conta a proteção decorrente de seguros que, consoante a legislação nacional, não sejam obrigatórias para as pessoas amparadas, desde que:

a) sejam controlados pelas autoridades públicas ou administrados, em comum, de acordo com normas determinadas, pelos empregadores e os empregados;

b) abrangem uma parte substancial de pessoas cujos proventos não ultrapassem os de um operário qualificado do sexo masculino;

c) satisfeito conjuntamente com outras modalidades de amparo, se for o caso, aos dispositivos desta convenção que lhes dizem respeito.

\section{PARTE II SERVIÇOS MÉDICOS}

Art. $7^{\circ}$ - O Membro para o qual a presente Parte da convenção estiver em vigor, deve assegurar prestações de serviços médicos de caráter preventivo ou curativo às pessoas amparadas quando seu estado de saúde assim o exigir, de acordo com os seguintes artigos desta Parte.

Art. $8^{\circ}-\mathrm{O}$ evento coberto deve abranger qualquer estado mórbido, seja qual for a sua causa, a gestação, o parto e suas consequiências.

Art. $9^{\circ}$ - As pessoas amparadas devem abranger:

a) quer determinadas categorias de assalariados, perfazendo, no mínimo, 50 por cento da totalidade dos assalariados, bem como suas esposas e filhos;

b) quer determinadas categorias da população ativa, perfazendo, no mínimo, 20 por cento da totalidade dos residentes, bem como as esposas e filhos dos integrantes dessas categorias;

c) quer determinadas categorias de residentes, perfazendo no mínimo 50 por cento da totalidade desses;

d) quer, no caso de ter sido feita uma declaração nos termos do artigo $3^{\circ}$, determinadas categorias de assalariados, perfazendo, no mínimo, 50 por cento da totalidade dos assalariados que trabalham em empresas industriais que empreguem 20 pessoas, pelo menos, bem como as esposas e filhos dos assalariados dessas categorias.

Art. 10 - 1. As prestações devem abranger, no mínimo: 
a) em caso de estado mórbido:

I) os serviços de médicos que exerçam a clínica geral, inclusive visitas domiciliares;

II) os serviços de especialistas prestados em hospitais a pessoas hospitalizadas ou não e ainda os que podem ser administrados fora dos hospitais;

III) fornecimento de produtos farmacêuticos indispensáveis mediante receita passada por médico;

IV) hospitalização, quando necessária;

b) em caso de gestação, parto e suas conseqüências:

I) assistência pré-natal, assistência durante o parto e assistência após o parto, prestada por médico ou parteira diplomada;

II) hospitalização, em caso de necessidade.

2. O beneficiário ou o respectivo responsável podem ser obrigados a concorrer para as despesas com os serviços médicos recebidos em caso de doença; os dispositivos relativos a esta participação devem ser estabelecidos de tal forma que não impliquem ônus por demais pesado.

3. As prestações fornecidas de acordo com o presente artigo devem visar a conservar, restabelecer ou melhorar a saúde, bem como a capacidade de trabalho da pessoa amparada e a atender às suas necessidades pessoais.

4. As repartições do Governo ou as instituições que dispensarem essas prestações devem incentivar as pessoas amparadas, por todos os meios que julgarem apropriados, a recorrer aos serviços gerais de saúde postos à sua disposição pelas autoridades públicas ou por outros organismos reconhecidos pelas autoridades públicas.

Art. 11 - As prestações mencionadas no artigo 10, no evento coberto devem ser asseguradas, pelo menos, às pessoas amparadas que completarem ou cujo responsável houver completado um estágio considerado necessário para evitar abusos.

Art. 12 - 1. As prestações mencionadas no artigo 10 devem ser concedidas durante todo o evento coberto, com a exceção de que, em caso de doença, a duração das prestações pode ser limitada há 26 semanas por caso; todavia, as prestações de assistência médica não podem ser suspensas enquanto estiver sendo pago um auxílio-doença e devem tomar-se providências para elevar o limite supramencionado quando se tratar de doenças previstas na legislação nacional e para as quais se reconhece a necessidade de assistência médica prolongada.

2. No caso de ter sido feita uma declaração nos termos do artigo $3^{\circ}$, a duração das prestações 
de assistência médica pode ser limitada há 13 semanas por caso.

\section{PARTE III AUXÍLIO-DOENÇA}

Art. 13 - O Membro para o qual a presente Parte da Convenção estiver em vigor, deve assegurar o pagamento de auxílio-doença às pessoas amparadas, de acordo com os seguintes artigos desta Parte.

Art. $14-\mathrm{O}$ evento coberto deve abranger a incapacidade de trabalho decorrente de um estado mórbido que acarrete a suspensão de ganhos, conforme for definida pela legislação nacional.

Art. 15 - As pessoas amparadas devem abranger:

a) quer determinadas categorias de assalariadas, perfazendo, no mínimo, 50 por cento da totalidade dos assalariados;

b) quer determinadas categorias da população ativa, perfazendo, no mínimo, 20 por cento da totalidade dos residentes;

c) querem todos os residentes cujos recursos durante o evento não excederem determinados limites de acordo com o disposto no artigo 67;

d) quer, no caso de ter sido feita uma declaração nos termos do artigo $3^{\circ}$, determinadas categorias de assalariados, perfazendo, no mínimo, 50 por cento da totalidade dos assalariados que trabalham em empresas industriais que empreguem 20 pessoas, pelo menos.

Art. 16 - 1. Quando forem amparadas categorias de assalariados ou categorias da população ativa, a prestação consistirá em um pagamento periódico calculado de acordo com as disposições do artigo 65 ou do artigo 66.

2. Quando forem amparados todos os residentes cujos recursos durante o evento não excederem determinados limites, o auxílio consistirá em um pagamento periódico calculado de acordo com o que dispõe o artigo 67.

Art. 17 - A prestação mencionada no artigo 16, no evento coberto, deve ser assegurada, no mínimo, às pessoas amparadas que completaram um período de carência considerado suficiente para evitar abusos.

Art. 18 - 1. A prestação mencionada no artigo 16 deve ser concedida durante todo o evento com a ressalva de que a duração da prestação possa ser limitada a 26 semanas por caso de doença, com a possibilidade de não ser paga a prestação nos três primeiros dias da suspensão dos ganhos.

2. No caso de ter sido feita uma declaração nos termos do artigo $3^{\circ}$, a duração da prestação pode ser limitada: 
a) que a um período tal que o número total de dias para os quais for concedido o auxíliodoença no decorrer de um ano não seja inferior a dez vezes o número médio de pessoas amparadas durante esse mesmo ano;

b) quer a 13 semanas por caso de doença, com a possibilidade de não ser paga a prestação nos três primeiros dias da suspensão dos ganhos.

\section{PARTE IV PRESTAÇÕES DE DESEMPREGO}

Art. 19 - O Membro para o qual a presente Parte da Convenção estiver em vigor, deve assegurar às pessoas amparadas prestações de desemprego de acordo com os seguintes artigos desta Parte.

Art. 20 - O evento coberto deve abranger toda suspensão de ganhos, tal como for definida pela legislação nacional, devido à impossibilidade de obtenção de um emprego adequado, por parte de pessoa amparada, que seja capaz de trabalhar e esteja disponível para o trabalho.

Art. 21 - As pessoas amparadas devem abranger:

a) quer determinadas categorias de assalariados, perfazendo, no mínimo, 50 por cento da totalidade dos assalariados;

b) querem todos os residentes cujos recursos durante o evento não excederem determinados limites, de acordo com o disposto no artigo 67;

c) quer, no caso de ter sido feita uma declaração nos termos do artigo 3, determinadas categorias de assalariados, perfazendo, no mínimo, 50 por cento da totalidade dos assalariados que trabalham em empresas industriais que empreguem 20 pessoas pelo menos.

Art. 22 - 1. Quando forem amparadas categorias de assalariados, a prestação consistirá em um pagamento periódico calculado segundo as disposições do artigo 65 ou do artigo 66.

2. Quando forem amparados todos os residentes cujos recursos durante o evento não excederem determinados limites, a prestação consistirá em um pagamento periódico calculado de acordo com os dispositivos do artigo 67.

Art. 23 - A prestação mencionada no artigo 22, no evento coberto, deve ser assegurada, no mínimo, às pessoas amparadas que completarem período de carência considerado suficiente para evitar abusos.

Art. 24 - 1. A prestação mencionada no artigo 22 deve ser concedida durante todo o evento, com a exceção de que a duração da prestação pode ser limitada:

a) quando são amparadas categorias de assalariados, a 13 semanas no decurso de um período de 12 meses; 
b) quando são amparados todos os residentes cujos recursos durante o evento não excederem determinados limites, a 26 semanas no decurso de um período de 12 meses.

2. Quando a duração da prestação for escalonada, em virtude da legislação nacional, segundo a duração da contribuição ou segundo as prestações anteriormente recebidas no decurso de um período determinado, os dispositivos da alínea a do parágrafo 1 considerar-se-ão cumpridos se a duração média da prestação abranger, no mínimo, 13 semanas no decurso de um período de 12 meses.

3. A prestação pode deixar de ser efetuada durante um prazo de carência limitado aos sete primeiros dias em cada caso de suspensão dos ganhos, computando-se os dias de desemprego antes e depois de um emprego temporário que não passe de uma duração determinada, como fazendo parte do mesmo caso de suspensão de ganhos.

4. Tratando-se de operários cuja ocupação depender das estações do ano (trabalhadores sazonais), a duração da prestação e o prazo de carência podem ser adaptados às condições do emprego.

\section{PARTE V APOSENTADORIA POR VELHICE}

Art. 25 - O Membro para o qual a presente Parte da convenção estiver em vigor, deve assegurar às pessoas amparadas aposentadoria por velhice, de acordo com os seguintes artigos desta Parte.

Art. $26-1$. O evento coberto será a sobrevivência além de uma determinada idade prescrita.

2. A idade determinada não deverá ultrapassar a de 65 anos. Todavia, poderá ser fixada, pelas autoridades competentes, uma idade mais avançada, tomando-se em consideração a capacidade de trabalho das pessoas idosas no país em apreço.

3. A legislação nacional poderá suspender a prestação se a pessoa que a ela teria direito exercer determinadas atividades remuneradas ou poderá diminuir as prestações contributivas quando os ganhos do beneficiário ultrapassarem uma quantia determinada e as prestações não contributivas quando os ganhos do beneficiário ou seus outros recursos, ou os dois somados, excederem uma quantia determinada.

Art. 27 - As pessoas amparadas devem abranger:

a) quer determinadas categorias de assalariados perfazendo, no mínimo, 50 por cento da totalidade dos assalariados;

b) quer determinadas categorias da população ativa, perfazendo, no mínimo, 20 por cento da totalidade dos residentes;

c) querem todos os residentes cujos recursos durante o evento não excederem determinados limites de acordo com o disposto no artigo 67; 
d) quer, no caso de ter sido feita uma declaração nos termos do artigo $3^{\circ}$, determinadas categorias de assalariados, perfazendo, no mínimo, 50 por cento da totalidade dos assalariados que trabalham em empresas industriais, que empreguem 20 pessoas, pelo menos.

Art. 28 - A prestação consistirá em um pagamento periódico calculado como segue:

a) de acordo com os dispositivos do artigo 65 ou do artigo 66, conforme se tratar de pessoas amparadas pertencentes às categorias de assalariados ou às categorias da população ativa;

b) de acordo com os dispositivos do artigo 67, quando forem amparados todos os residentes cujos recursos durante o evento não ultrapassarem determinados limites.

Art. 29 - 1. A prestação mencionada no artigo 28, deve, no evento coberto, ser assegurada, no mínimo:

a) a uma pessoa amparada que houver completado, antes de se verificar o evento, segundo regras determinadas, um período de carência que pode consistir seja em 30 anos de contribuição ou de emprego, seja em 20 anos de residência;

b) quando, em princípio, todas as pessoas ativas forem amparadas, a uma pessoa que houver completado um determinado período de contribuições e em nome da qual foram efetuadas, no decurso do período ativo de sua vida, contribuições cujo número anual médio atinja a uma quantia determinada.

2. Quando a prestação mencionada no parágrafo 1 estiver subordinada à integração de um período mínimo de contribuição ou de emprego, uma prestação reduzida deve ser assegurada, no mínimo:

a) a uma pessoa amparada que houver completado antes de se verificar o evento segundo regras determinadas, um período de carência de 15 anos de contribuições ou de emprego;

b) quando, em princípio, todas as pessoas ativas forem amparadas, a uma pessoa que houver completado um determinado período de contribuições e em nome da qual foi efetuado, no decurso do período ativo de sua vida, o pagamento da metade do número médio de contribuições anuais determinadas em conformidade com o disposto na alínea $\mathrm{b}$ do parágrafo 1 do presente artigo.

3. Os dispositivos do parágrafo 1 do presente artigo considerar-se-ão cumpridos quando uma prestação calculada de acordo com a Parte XI, mas segundo uma percentagem inferior de 10 unidades àquela que está indicada na tabela anexa à referida Parte para o beneficiário-padrão, for assegurada a toda pessoa amparada que houver completado de acordo com as regras estabelecidas, seja 10 anos de contribuições ou de emprego, seja 5 anos de residência.

4. Uma redução proporcional da porcentagem indicada na tabela anexa à referida Parte XI pode ser feita quando o período de carência determinado para a outorga da prestação que 
corresponde à porcentagem reduzida for superior a 10 anos de contribuições ou de emprego, mas inferior a 30 anos de contribuições ou de emprego. Quando o referido período for superior a 15 anos, uma prestação reduzida será concedida conforme o parágrafo 2 do presente artigo.

5. Quando a concessão da prestação mencionada nos parágrafos 1,3 ou 4 do presente artigo estiver subordinada à integração de um período mínimo de contribuições, uma prestação reduzida deve ser assegurada, nas condições determinadas, a uma pessoa amparada, a qual, pelo simples fato de já ter atingido a idade avançada quando os dispositivos que permitem a aplicação da presente Parte do Convênio entrarem em vigor, não puder preencher as condições determinadas nos termos do parágrafo 2 do presente artigo, a não ser que uma prestação de acordo com os dispositivos dos parágrafos 1, 3 ou 4 seja concedida a uma tal pessoa em idade mais avançada do que a normal.

Art. 30 - As prestações mencionadas nos artigos 28 e 29 devem ser concedidas durante toda a duração do evento.

\section{PARTE VI PRESTAÇÕES EM CASO DE ACIDENTES DE TRABALHOE DE DOENÇAS PROFISSIONAIS}

Art. 31 - O Membro para o qual a presente Parte do Convênio estiver em vigor, deve assegurar às pessoas amparadas prestações em caso de acidentes de trabalho e de doenças profissionais, de acordo com os seguintes artigos desta Parte.

Art. 32 - Os eventos cobertos devem abranger as seguintes hipóteses, quando devidos a acidentes de trabalho ou a doenças profissionais:

a) estado mórbido;

b) incapacidade para o trabalho decorrente de um estado mórbido tendo como resultado a suspensão dos ganhos tal como está definida pela legislação nacional;

c) perda total da capacidade de ganho ou perda parcial da capacidade de ganho ultrapassando um limite determinado, quando for provável que esta perda total ou parcial seja permanente; ou diminuição correspondente da integridade física;

d) perda dos meios de subsistência sofrida pela viúva ou filhos em consequiência da morte do arrimo de família; no caso da viúva, o direito à prestação pode estar em conformidade com a legislação nacional, de que ela é incapaz de prover ao seu próprio sustento.

Art. 33 - As pessoas amparadas devem abranger:

a) quer determinadas categorias de assalariados perfazendo, no mínimo, 50 por cento da totalidade dos assalariados e, no caso de o direito à prestação decorrer da morte do arrimo de família, igualmente as esposas e filhos dos assalariados dessas categorias;

b) quer, no caso de ter sido feita uma declaração nos termos do artigo $3^{\circ}$, determinadas 
categorias de assalariados perfazendo, no mínimo, 50 por cento da totalidade dos assalariados que trabalham em empresas industriais que empreguem 20 pessoas pelo menos, e, no caso de o direito às prestações decorrer da morte do arrimo de família, igualmente as esposas e filhos dos assalariados dessas categorias.

Art. $34-1$. No que diz respeito a um estado mórbido, as prestações devem abranger a assistência médica mencionada nos parágrafos 2 e 3 do presente artigo.

2. A assistência médica deve abranger:

a) assistência de clínico de medicina geral ou de especialista a pessoas hospitalizadas, ou não, inclusive visitas a domicílio;

b) assistência dentária;

c) serviços de enfermagem, seja a domicílio seja em hospital ou outra instituição médica;

d) a manutenção em hospital, casa de repouso, sanatório ou outra instituição médica;

e) fornecimento de artigos dentários e de produtos farmacêuticos e outros artigos médicos ou cirúrgicos, inclusive aparelhos de prótese e sua conservação, bem como óculos;

f) assistência prestada por membro de outra profissão legalmente reconhecida como ligada à profissão médica, sob a fiscalização de um médico ou dentista.

3. Tendo sido feita uma declaração nos termos do artigo $3^{\circ}$, a assistência médica deve incluir, no mínimo:

a) assistência por clínico de medicina geral, inclusive visitas domiciliares;

b) assistência por especialista ministrada em hospitais a pessoas hospitalizadas ou não, e assistência por especialistas que pode ser administrada fora de hospitais;

c) fornecimento de produtos farmacêuticos indispensáveis, sob receita passada por médico ou outro prático habilitado;

d) hospitalização quando necessária.

4. A assistência médica prestada em conformidade com os parágrafos anteriores deve tender a conservar, restabelecer ou melhorar a saúde bem como a capacidade de trabalho das pessoas amparadas a atender às suas necessidades pessoais.

Art. 35 - 1. As repartições do Governo ou as instituições encarregadas da administração da assistência médica devem cooperar, quando for oportuno, com os serviços gerais de reeducação profissional, visando a readaptação das pessoas de capacidade diminuída a um trabalho apropriado. 
2. A legislação nacional pode autorizar os referidos departamentos ou instituições a tomarem medidas visando à recuperação profissional das pessoas de capacidade diminuída.

Art. 36 - 1. No que diz respeito à incapacidade para o trabalho ou à perda total da capacidade de ganho, quando é provável que esta perda seja permanente, ou à diminuição correspondente da integridade física, ou à morte do arrimo de família, a prestação corresponderá a um pagamento periódico calculado de acordo com os dispositivos do artigo 65 ou do artigo 66.

2. Em caso de perda parcial da capacidade de ganho, quando for provável que esta perda seja permanente, ou no caso de uma diminuição correspondente da integridade física, a prestação, quando devida consistirá em um pagamento periódico fixado proporcional e eqüitativamente, de acordo com a prestação prevista para o caso da perda total da capacidade de ganho ou de uma diminuição correspondente da integridade física.

3. Os pagamentos periódicos poderão ser convertidos em uma quantia paga de uma só vez:

a) quando a incapacidade for mínima; ou

b) quando se fornecer às autoridades competentes a garantia de um emprego adequado.

Art. 37 - As prestações mencionadas nos artigos 34 e 36 devem, no evento coberto, ser asseguradas, no mínimo, às pessoas amparadas que estavam empregadas como assalariadas no território do Membro, no momento do acidente ou no momento em que a doença foi contraída e, em se tratando de pagamentos periódicos, resultantes da morte do arrimo de família, à viúva e aos filhos do falecido.

Art. 38 - As prestações mencionadas nos artigos 34 e 36 devem ser concedidas durante toda a duração do evento, todavia, no que diz respeito à incapacidade para o trabalho, a prestação poderá deixar de ser efetuada para os três primeiros dias de cada caso de suspensão de ganho.

\section{PARTE VII PRESTAÇÕES DE FAMÍLIA}

Art. 39 - O Membro para o qual a presente Parte da Convenção estiver em vigor, deve assegurar às pessoas amparadas prestações familiares, de acordo com os seguintes artigos desta Parte.

Art. 40 - O evento coberto será a responsabilidade pela manutenção de crianças, conforme for determinado.

Art. 41 - As pessoas amparadas devem abranger:

a) quer determinadas categorias de assalariados, perfazendo, no mínimo, 50 por cento da totalidade dos assalariados;

b) quer determinadas categorias da população ativa perfazendo, no mínimo, 20 por cento da 
totalidade dos residentes;

c) quer todos os residentes cujos recursos durante o evento previsto não ultrapassarem determinados limites;

d) quer, no caso de ter sido feita uma declaração nos termos do artigo $3^{\circ}$, determinadas categorias de assalariados, perfazendo, no mínimo, 50 por cento dos assalariados que trabalham em empresas industriais que empreguem 20 pessoas, pelo menos.

Art. 42 - As prestações devem consistir:

a) seja em um pagamento periódico concedido a toda pessoa amparada que houver completado o período de carência determinado;

b) seja no fornecimento às crianças, ou para as crianças, de alimentos, roupas, habitação, local para férias ou assistência domiciliar;

c) seja em uma combinação das prestações especificadas nas alíneas a e b.

Art. 43 - As prestações mencionadas no artigo 42 deve ser asseguradas, no mínimo, a uma pessoa amparada que houver completado um determinado período de carência, que pode consistir seja em três meses de contribuição ou de emprego, seja em um ano de residência, segundo o que for determinado.

Art. $44-\mathrm{O}$ valor total das prestações concedidas às pessoas amparadas nos termos do artigo 42 deverá ser calculado de forma a corresponder:

a) quer a 3 por cento do salário de um trabalhador comum, adulto, do sexo masculino, determinado de acordo com os dispositivos do artigo 66, multiplicado pelo número total de filhos de todas as pessoas protegidas;

b) quer a 1,5 por cento do salário acima multiplicado pelo número total de filhos de todos os residentes.

Art. 45 - Se as prestações consistirem em um pagamento periódico, devem ser concedidas durante toda a duração do evento.

\section{PARTE VIII PRESTAÇÕES DE MATERNIDADE}

Art. 46 - O Membro para o qual a presente Parte da convenção estiver em vigor, deve assegurar prestações de maternidade às pessoas amparadas, de acordo com os seguintes artigos desta Parte.

Art. 47 - O evento coberto será a gravidez, o parto e suas consequiências, bem como a suspensão de ganhos daí decorrente tal como se achar definida na legislação nacional. 
Art. 48 - As pessoas amparadas devem abranger:

a) quer todas as mulheres pertencentes a determinadas categorias de assalariados, categorias estas perfazendo, no mínimo, 50 por cento da totalidade dos assalariados e, no que diz respeito à assistência médica à maternidade igualmente as esposas de homens pertencentes a estas mesmas categorias;

b) quer todas as mulheres pertencentes a determinadas categorias de população ativa, categorias estas perfazendo, no mínimo, 20 por cento da totalidade dos residentes e, no que diz respeito à assistência médica à maternidade, igualmente as esposas de homens pertencentes a estas mesmas categorias;

c) quer, no caso de ter sido feita uma declaração nos termos do artigo $3^{\circ}$, todas as mulheres pertencentes a determinadas categorias de assalariados, categorias estas perfazendo, no mínimo, 50 por cento da totalidade dos assalariados que trabalham em empresas industriais que empreguem 20 pessoas pelo menos e, no que diz respeito à assistência médica à maternidade, igualmente as esposas de homens pertencentes a estas mesmas categorias.

Art. 49 - 1. No que diz respeito à gravidez, ao parto e às suas conseqüências, a assistência médica à maternidade deve abranger os serviços mencionados nos parágrafos 2 e 3 do presente artigo.

2. Os serviços médicos devem abranger, no mínimo:

a) assistência pré-natal, assistência durante o parto e assistência após o parto, prestadas por médico ou por parteira diplomada;

b) hospitalização quando for necessária.

3. Os serviços médicos mencionados no parágrafo 2 do presente artigo devem tender a conservar, restabelecer ou melhorar a saúde bem como a capacidade de trabalho da mulher amparada e atender às suas necessidades pessoais.

4. As repartições do Governo ou as instituições encarregadas da administração da assistência médica em caso de maternidade devem incentivar as mulheres amparadas, por todos os meios considerados úteis, a recorrer aos serviços gerais de saúde postos à sua disposição pelas autoridades públicas ou por outros organismos reconhecidos pelas autoridades públicas.

Art. 50 - No que diz respeito à suspensão de proventos decorrentes da gravidez, do parto e de suas consequiências, a prestação consistirá em um pagamento periódico calculado de acordo com os dispositivos do artigo 65 ou do artigo 66. A importância do pagamento periódico poderá variar no decorrer do evento contanto que a importância média seja conforme aos dispositivos precitados.

Art. 51 - As prestações mencionadas nos artigos 49 e 50, no evento coberto, devem ser asseguradas, pelo menos, a uma mulher pertencente às categorias amparadas que houver 
completado período de carência considerado suficiente para evitar abusos; as prestações mencionadas no artigo 49 devem igualmente ser asseguradas às esposas de homens pertencentes às categorias amparadas quando estes completarem o período de carência previsto.

Art. 52 - As prestações mencionadas nos artigos 49 e 50 devem ser concedidas durante toda a duração do evento; todavia, os pagamentos periódicos podem ser limitados a doze semanas, a não ser que um período mais longo de abstenção do trabalho seja imposto ou autorizado pela legislação nacional, caso em que os pagamentos não poderão ser limitados a um período de menor duração.

\section{PARTE IX APOSENTADORIA POR INVALIDEZ}

Art. 53 - O Membro para o qual a presente Parte da convenção estiver em vigor, deve assegurar a aposentadoria por invalidez às pessoas amparadas, de acordo com os seguintes artigos do referido capítulo desta Parte.

Art. 54 - O evento coberto é a incapacidade de exercer uma atividade profissional, de um grau determinado, quando for provável que esta incapacidade seja permanente ou que perdurará após a cessação do auxílio doença.

Art. 55 - As pessoas amparadas devem abranger:

a) quer determinadas categorias de assalariados, perfazendo, no mínimo, 50 por cento da totalidade dos assalariados;

b) quer determinadas categorias da população ativa, perfazendo, no mínimo, 20 por cento da totalidade dos residentes;

c) quer todos os residentes cujos recursos durante o evento não ultrapassarem determinados limites, de acordo com os dispositivos do artigo 67;

d) quer, no caso de ter sido feita uma declaração nos termos do artigo $3^{\circ}$, determinadas categorias de assalariados, perfazendo, no mínimo 50 por cento da totalidade dos assalariados que trabalhem em empresas industriais que empreguem 20 pessoas, pelo menos.

Art. 56 - A prestação consistirá em um pagamento periódico calculado da seguinte forma:

a) de acordo com os dispositivos do artigo 65 ou do artigo 66, conforme as pessoas amparadas pertencerem a categorias de assalariados ou a categorias da população ativa;

b) de acordo com os dispositivos do artigo 67, quando forem amparadas todas as pessoas cujos recursos durante o evento não ultrapassarem determinados limites.

Art. 57 - 1. A prestação mencionada no artigo 56, no evento coberto, deve ser assegurada, pelo menos: 
a) a uma pessoa amparada que houver completado antes de se verificar o evento, segundo determinadas regras, um período de carência que pode consistir seja em 15 anos de contribuições, ou seja, em 10 anos de residência;

b) quando, em princípio, todas as pessoas ativas forem amparadas, a uma pessoa que houver completado um período de carência de três anos de contribuições e em nome da qual foi efetivado, no decurso do período ativo de sua vida, o pagamento de contribuições, cujo número anual médio atinge uma determinada quantia.

2. Quando a prestação mencionada no parágrafo 1 estiver subordinada à integração de um período mínimo de contribuições ou de emprego, uma prestação reduzida deve ser assegurada, no mínimo:

a) a uma pessoa amparada que houver completado antes de se verificar o evento, segundo determinadas regras, um período de carência de cinco anos de contribuições ou de emprego;

b) quando, em princípio, todas as pessoas ativas forem amparadas, a uma pessoa que houver completado um período de carência de três anos de contribuições e em nome da qual foi efetuado, no decurso do período ativo de sua vida, o pagamento da metade do número médio de contribuições anuais determinado, ao qual se refere à alínea $b$ do parágrafo 1 do presente artigo.

3. Os dispositivos do parágrafo 1 do presente artigo considerar-se-ão cumpridos quando uma prestação calculada em conformidade com a Parte XI, mas segundo uma percentagem inferior de 10 unidades àquela que está indicada na tabela anexa à referida Parte para o beneficiáriopadrão, for assegurada a toda pessoa amparada que houver completado, segundo as regras determinadas, 5 anos de contribuições, de emprego ou de residência.

4. Uma redução proporcional da porcentagem indicada na tabela anexa à Parte XI pode ser feita quando o período de carência para a prestação correspondente à percentagem reduzida for superior a 5 anos de contribuições ou de emprego, mas inferior a 15 anos de contribuições ou de emprego. Uma prestação reduzida será concedida nos termos do parágrafo 2 do presente artigo.

Art. 58 - As prestações mencionadas nos artigos 56 e 57 devem ser concedidas durante toda a duração do evento ou até quando forem substituídas pela velhice.

\section{PARTE X PENSÃO POR MORTE}

Art. 59 - O Membro para o qual a presente Parte do Convênio estiver em vigor deve assegurar às pessoas amparadas a pensão por morte — de acordo com os seguintes artigos desta Parte.

Art. $60-1$. O evento coberto deve abranger a perda dos meios de subsistência sofrida pela viúva ou filhos em conseqüência da morte do chefe de família; no caso da viúva, o direito à 
prestação pode estar subordinado à presunção de que ela é incapaz de prover ao próprio sustento.

2. A legislação nacional poderá suspender a prestação se a pessoa que a ela teria direito exercer determinadas atividades remuneradas, ou poderá diminuir as prestações, se contributivas, quando os ganhos da beneficiária ultrapassarem uma importância determinada e, se não contributivas, quando os ganhos da beneficiária ou seus outro recursos, ou os dois somados, ultrapassarem uma importância determinada.

Art. 61 - As pessoas amparadas devem abranger:

a) quer as esposas e os filhos de chefes de família pertencentes a determinadas categorias de assalariados, perfazendo, no mínimo, 50 por cento da totalidade dos assalariados;

b) quer as esposas e os filhos dos chefes de família pertencentes a determinadas categorias da população ativa, perfazendo, no mínimo, 20 por cento da totalidade dos residentes;

c) quer todas as viúvas e todos os filhos, contanto que possuam a qualidade de residentes, que perderam o chefe de família e cujos recursos durante o evento não ultrapassarem os limites determinados de acordo com os dispositivos do artigo 67;

d) quer, no caso de ter sido feita uma declaração nos termos do artigo $3^{\circ}$, as esposas e filhos de chefes de família pertencentes a determinadas categorias de assalariados, perfazendo, no mínimo, 50 por cento da totalidade dos assalariados que trabalham em empresas industriais que empreguem 20 pessoas, pelo menos.

Art. 62 - A prestação consistirá em um pagamento periódico calculado da seguinte maneira:

a) de acordo com os dispositivos do artigo 65 ou do artigo 66, conforme sejam preparadas categorias de assalariados ou categorias da população ativa;

b) de acordo com os dispositivos do artigo 67 quando forem amparados todos os residentes cujos recursos durante o evento não ultrapassarem determinados limites.

Art. 63 - 1. A prestação mencionada no artigo 62, no evento coberto, deve ser assegurada, no mínimo:

a) a uma pessoa amparada cujo chefe de família houver completado, em conformidade com determinadas regras, um período de carência que pode consistir seja em 15 anos de contribuições ou de emprego, seja em 10 anos de residência;

b) quando, em princípio, as esposas e os filhos de todas as pessoas ativas forem amparados, a uma pessoa amparada cujo chefe de família houver completado um período de carência de três anos de contribuições, sob a condição de terem sido pagas em nome desse chefe de família, no decurso do período ativo de sua vida, contribuições cujo número médio anual atinja uma determinada quantia. 
2. Quando a concessão da prestação mencionada no parágrafo 1 estiver subordinada à integração de um período mínimo de contribuição ou de emprego, uma prestação reduzida deve ser assegurada, pelo menos:

a) a uma pessoa amparada cujo chefe de família houver completado, de acordo com determinadas regras, um período de carência de 5 anos de contribuições ou de emprego;

b) quando, em princípio, as esposas e os filhos de todas as pessoas ativas forem amparados, a uma pessoa amparada cujo chefe de família houver completado um período de carência de 3 anos de contribuições, sob a condição de ter sido efetuado, em nome deste chefe de família, no decurso de sua vida ativa, a metade do número médio anual de contribuições ao qual se refere à alínea $\mathrm{b}$ do parágrafo 1 do presente artigo.

3. Os dispositivos do parágrafo 1 do presente artigo considerar-se-ão cumpridos quando, no mínimo, uma prestação calculada em conformidade com a Parte XI, porém, segundo uma porcentagem inferior de 10 unidades à prestação indicada na tabela anexa àquela Parte para o beneficiário-padrão for assegurada a toda pessoa amparada cujo chefe de família houver completado, de acordo com determinadas regras, 5 anos de contribuições, de emprego ou de residência.

4. Uma redução proporcional da porcentagem indicada na tabela anexa à Parte XI pode ser feita quando o período de carência para a prestação que corresponde à porcentagem reduzida for superior a 5 anos de contribuições ou de emprego, porém inferior a 15 anos de contribuições ou de emprego. Uma prestação reduzida será concedida de acordo com o parágrafo 2 do presente artigo.

5. Uma duração mínima do casamento pode ser estipulada para que uma viúva sem filho, presumida incapaz de prover à própria subsistência, tenha direito à pensão por morte.

Art. 64 - As prestações mencionadas nos artigos 62 e 63 devem ser concedidas durante toda a duração do evento.

\section{PARTE XI CÁLCULO DOS PAGAMENTOS PERIÓDICOS}

Art. 65 - 1. Para todo pagamento periódico ao qual se aplica o presente artigo, o montante da prestação acrescido do montante das prestações de família concedidas durante o evento, deverá ser tal que, para o beneficiário-padrão, objeto da tabela anexa à presente Parte, seja, no mínimo, igual, para o evento em apreço, à porcentagem indicada nessa tabela com relação ao total dos ganhos anteriores do beneficiário ou de seu chefe de família e do montante das prestações às famílias concedidas a uma pessoa amparada tendo os mesmos encargos de família que o beneficiário-padrão.

2. Os ganhos anteriores do beneficiário ou de seu chefe de família serão calculados em conformidade com as regras determinadas e, quando as pessoas amparadas ou seus chefes de família estiverem distribuídos em classes, de acordo com os respectivos ganhos anteriores, 
poderão ser calculados segundo os ganhos básicos das classes às quais pertencerem.

3. Um máximo poderá ser prescrito para o montante da prestação ou para os ganhos que são levados em conta para o cálculo da prestação, sob a condição de que esse máximo seja estabelecido de maneira a garantir o cumprimento dos dispositivos do parágrafo 1 do presente artigo no caso em que os ganhos anteriores do beneficiário ou de seu chefe de família sejam inferiores ou iguais ao salário de um operário qualificado do sexo masculino.

4. Os ganhos anteriores do beneficiário ou de seu chefe de família, o salário do operário qualificado do sexo masculino, a prestação geral e as de família serão calculados sobre os mesmos tempos-base.

5. Para os outros beneficiários, a prestação será fixada de maneira a representar uma proporção eqüitativa da do beneficiário-padrão.

6. Para os fins da aplicação do presente artigo, um operário qualificado do sexo masculino será:

a) quer um instalador ou um torneiro na indústria mecânica, exceto a de máquinas elétricas;

b) quer um operário qualificado padrão, definido de acordo com os dispositivos do parágrafo seguinte;

c) quer uma pessoa cujos ganhos sejam iguais ou superiores aos ganhos de 75 por cento de todas as pessoas amparadas, fixados em base anual ou com base em um período mais curto, conforme o que for determinado;

d) quer uma pessoa cujos ganhos são iguais a 125 por cento dos ganhos médios de todas as pessoas amparadas.

7. O operário qualificado padrão, para a aplicação da alínea b do parágrafo precedente, será escolhido na classe que abranger o maior número de pessoas do sexo masculino amparadas pelo evento em apreço ou de chefes de família de pessoas amparadas, no ramo que ocupa o maior número destas pessoas amparadas ou destes chefes de família; com esta finalidade utilizar-se-á a classificação internacional padrão, por indústria, de todos os ramos da atividade econômica, adotada pelo Conselho Econômico e Social da Organização das Nações Unidas na sua Sétima Sessão, a 27 de agosto de 1948, que se acha reproduzida no anexo à presente Convenção, levando-se em conta quaisquer modificações por ventura introduzidas.

8. Quando as prestações variarem de uma região para outra, um operário qualificado, do sexo masculino, poderá ser escolhido em cada região de acordo com os dispositivos dos parágrafos 6 e 7 do presente artigo.

9. O salário do operário qualificado, do sexo masculino, será estipulado na base do salário para um número normal de horas de trabalho fixado por convenções coletivas ou, na falta destes, pela legislação nacional ou, ainda, em virtude desta última, pelo uso, inclusive dos abonos de carestia de vida, se for o caso; quando os salários assim fixados variarem de uma região para 
outra e no caso de o parágrafo 8 do presente artigo não ser aplicável, tomar-se-á um salário médio.

10. Os montantes dos pagamentos periódicos concedidos a título de aposentadoria por velhice, em caso de acidentes de trabalho e de doenças profissionais (com exceção das que são abrangidas pela incapacidade para o trabalho), à invalidez e em caso de morte do chefe de família deverão ser reajustados sempre que houver variações sensíveis no nível geral dos ganhos devidas a variações sensíveis do custo de vida.

Art. 66 - 1. Para todo pagamento periódico ao qual se aplica o presente artigo, o montante da prestação acrescido do montante das prestações de família concedidas durante o evento deverá ser tal que, para o beneficiário padrão, objeto da tabela anexa ao presente capítulo, seja, no mínimo, igual, para o evento em apreço, à porcentagem indicada nessa tabela com relação ao total do salário do trabalhador comum, adulto do sexo masculino e do montante das prestações de família concedidas a uma pessoa amparada tendo os mesmos encargos de família que o beneficiário-padrão.

2. O salário do trabalhador comum, adulto, do sexo masculino, a prestação geral e os de família serão calculados sobre os mesmos tempos-base.

3. Para os outros beneficiários, a prestação será estipulada de forma a representar uma proporção eqüitativa da do beneficiário-padrão.

4. Para a aplicação do presente artigo, o trabalhador comum, do sexo masculino será:

a) quer um trabalhador-padrão na indústria mecânica, exceto a de máquinas elétricas;

b) quer um trabalhador-padrão, de acordo com a definição contida nos dispositivos do parágrafo seguinte.

5. O trabalhador-padrão para a aplicação da alínea b do parágrafo precedente será escolhido na classe que abranger o maior número de pessoas do sexo masculino amparadas pelo evento em apreço ou de chefes de família de pessoas amparadas, no ramo que ocupa o maior número destas pessoas amparadas ou destes chefes de família; com esta finalidade, utilizar-se-á a classificação internacional padrão, por indústria, de todos os ramos da atividade econômica, adotada pelo Conselho Econômico e Social da Organização das Nações Unidas na sua Sétima Sessão, a 27 de agosto de 1948, que se acha reproduzida no anexo à presente convenção, levando-se em conta quaisquer modificações por ventura introduzidas.

6. Quando as prestações variarem de uma região para outra, um trabalhador comum, adulto, do sexo masculino poderá ser escolhido em cada região de acordo com os dispositivos dos parágrafos 4 e 5 do presente artigo.

7. O salário do trabalhador comum, adulto, do sexo masculino será estipulado na base do salário para um número normal de horas de trabalho fixado por convenções coletivas ou, na falta destas, pela legislação nacional, ou, ainda, em virtude desta última, pelo uso inclusive dos 
abonos de carestia de vida, se for o caso; quando os salários assim fixados variarem de uma região para outra e, no caso de o parágrafo 6 do presente artigo não ser aplicável, tomar-se-á um salário médio.

8. Os montantes dos pagamentos periódicos concedidos a título de aposentadoria por velhice, em caso de acidentes de trabalho e de doenças profissionais (com exceção das que são abrangidas pela incapacidade para o trabalho), à invalidez e em caso de morte do chefe de família, deverão ser reajustadas sempre que houver variações sensíveis no nível geral dos ganhos devidos a variações sensíveis do custo de vida.

Art. 67 - Para todo pagamento periódico ao qual se aplica o presente artigo:

a) o montante da prestação deve ser fixado de acordo com uma tarifa determinada ou de acordo com uma tarifa estabelecida pelas autoridades públicas competentes em conformidade com as regras determinadas;

b) o montante da prestação só pode ser reduzido na medida em que os outros recursos da família do beneficiário ultrapassarem os montantes substanciais prescritos ou fixados pelas autoridades públicas competentes de acordo com as regras determinadas;

c) o total da prestação e dos outros recursos, dedução feita dos montantes substanciais, objeto da alínea b acima, deve ser suficiente para garantir à família do beneficiário condições de vida sadias e adequadas e não deve ser inferior ao montante da prestação calculada de acordo com os dispositivos do artigo 66;

d) os dispositivos da alínea c considerar-se-ão cumpridos se o montante total das prestações pagas em observância ao capítulo em apreço ultrapassar de, pelo menos, 30 por cento o montante total das prestações que se obteria aplicando os dispositivos do artigo 66 e os dispositivos da:

I) alínea b do artigo 15 para o Capítulo III;

II) alínea b do artigo 27 para o Capítulo V;

III) alínea b do artigo 55 para o Capítulo IX;

IV) alínea b do artigo 61 para o Capítulo X;

Tabela (Anexa à Parte XI)

\begin{tabular}{|l|l|l|l|}
\hline Parte & Evento coberto & Beneficiário-padrão & Percentagem \\
\hline III & Doença & $\begin{array}{l}\text { Homem tendo esposa } \\
\text { e 2 filhos }\end{array}$ & 45 \\
\hline
\end{tabular}




\begin{tabular}{|c|c|c|c|}
\hline IV & Desemprego & $\begin{array}{l}\text { Homem tendo esposa } \\
\text { e } 2 \text { filhos }\end{array}$ & 45 \\
\hline V & Velhice & $\begin{array}{l}\text { Homem tendo esposa } \\
\text { em idade de } \\
\text { aposentadoria }\end{array}$ & 40 \\
\hline \multirow[t]{4}{*}{ VI } & $\begin{array}{l}\text { Acidentes de } \\
\text { Trabalho e Doença } \\
\text { Profissionais: }\end{array}$ & & \\
\hline & $\begin{array}{l}\text { Incapacidade para o } \\
\text { trabalho }\end{array}$ & $\begin{array}{l}\text { Homem tendo esposa } \\
\text { e } 2 \text { filhos }\end{array}$ & 50 \\
\hline & Invalidez & $\begin{array}{l}\text { Homem tendo esposa } \\
\text { e } 2 \text { filhos }\end{array}$ & 50 \\
\hline & Sobreviventes & Viúva tendo 2 filhos & 40 \\
\hline VIII & Maternidade & Mulher & 45 \\
\hline IX & Invalidez & $\begin{array}{l}\text { Homem tendo esposa } \\
\text { e } 2 \text { filhos }\end{array}$ & 40 \\
\hline $\mathrm{X}$ & Sobreviventes & Viúva tendo 2 filhos & 40 \\
\hline
\end{tabular}

\section{PARTE XII IGUALDADE DE TRATAMENTO PARA OS RESIDENTES ESTRANGEIROS}

Art. 68 - 1. Os residentes não nacionais devem gozar dos mesmos direitos que os residentes nacionais. Todavia, no que diz respeito às prestações ou às frações de prestações financiadas exclusivamente ou em sua maior parte pelos cofres públicos e, no que se refere aos regimes transitórios, podem ser prescritas disposições especiais relativamente aos estrangeiros e aos nacionais nascidos fora do território do Estado-Membro.

2. Nos sistemas de previdência social contributiva, cujo amparo se destina aos assalariados, as pessoas amparadas que são nacionais de um outro Membro que aceitou as obrigações decorrentes do capítulo em apreço do Convênio, devem, com relação ao referido capítulo, gozar dos mesmos direitos que os nacionais do Membro interessado. Todavia, a aplicação do presente parágrafo pode estar subordinada à existência de um acordo bilateral ou multilateral 
prevendo a reciprocidade.

\section{PARTE XIII DISPOSIÇÕES GERAIS}

Art. 69 - Uma prestação à qual uma pessoa amparada teria direito em virtude da aplicação de qualquer das Partes de II a X da presente convenção pode ser suspensa de uma forma a ser determinada:

a) enquanto o interessado não se encontrar no território do Membro;

b) enquanto o interessado estiver sendo sustentado pelos cofres públicos ou às custas de uma instituição ou de um serviço de previdência social; todavia, se a prestação exceder o custo desse sustento, a diferença deve ser paga às pessoas dependentes do beneficiário;

c) quando o interessado receber em espécie uma outra prestação de seguridade social, com exceção da prestação de família e, durante todo tempo que ele receber de terceiros um auxílio em virtude da mesma eventualidade prevista, com a ressalva de que a parte suspensa da prestação não exceda a outra prestação ou o auxílio recebido de terceiros;

d) quando o interessado tiver agido fraudulentamente para obter uma prestação;

e) quando o evento for provocado por delito cometido pelo interessado;

f) quando o evento for provocado por falta intencional do interessado;

g) nos casos apropriados, quando o interessado, por negligência, deixar de se utilizar dos serviços de assistência médica ou de readaptação postos à sua disposição ou não observar as regras determinadas para a verificação do evento ou para a conduta dos beneficiários;

h) no que diz respeito à prestação de desemprego, quando o interessado deixar de se utilizar dos serviços de procura de emprego à sua disposição;

i) no que diz respeito às prestações de desemprego, quando o interessado tiver perdido seu emprego em consequiência direta de uma paralisação de trabalho devida a um dissídio profissional ou quando tiver abandonado o trabalho espontaneamente sem justo motivo;

j) no que diz respeito à pensão por morte, enquanto a viúva viver em concubinato.

Art. 70 - 1. Todo requerente deve ter o direito de apelar em caso de recusa da prestação ou de contestação quanto à qualidade ou quantidade da mesma.

2. Quando, na aplicação da presente convenção, a administração da assistência médica estiver a cargo de um departamento do Governo responsável perante o Congresso, o direito de apelar previsto no parágrafo 1 do presente artigo, pode ser substituído pelo direito de requerer o exame, por parte da autoridade competente, de toda reclamação tendo por objeto a recusa de assistência médica ou a qualidade da assistência médica recebida. 
3. Quando os requerimentos forem submetidos a tribunais especiais instituídos para tratar de questões de seguridade social e nos quais as pessoas amparadas estejam representadas, o direito de apelação pode não se concedido.

Art. $71-1$. O custo das prestações concedidas em consequiência da aplicação da presente convenção e os gastos de administração dessas prestações devem ser financiados coletivamente por meio de contribuições ou de impostos ou pelos dois meios conjuntamente, de acordo com modalidades que evitem que as pessoas de poucos recursos tenham que suportar encargos por demais pesados e levem em consideração a situação econômica do Membro e das categorias de pessoas amparadas.

2. O total das contribuições de seguro a cargo dos assalariados amparados não deve ultrapassar 50 por cento do total dos recursos destinados ao amparo dos assalariados, de suas esposas e filhos. Para verificar se esta condição está sendo cumprida, todas as prestações concedidas pelo Membro em aplicação da convenção poderão ser consideradas em conjunto, com exceção das prestações de família e em caso de acidente de trabalho e de doenças profissionais, se estas últimas estiverem afeitas a um departamento especial.

3. O Membro deve assumir uma responsabilidade geral no que diz respeito às prestações concedidas em cumprimento à presente convenção e tomar todas as medidas necessárias para atingir as finalidades visadas; deve, se preciso for, certificar-se de que os estudos e cálculos necessários referentes ao equilíbrio financeiro são periodicamente executados por atuários e, em qualquer caso, antes de qualquer modificação das prestações, da taxa de contribuições de seguro ou dos impostos destinados à cobertura dos eventos em apreço.

Art. $72-1$. Quando a administração não estiver assegurada por uma instituição regulamentada pelas autoridades públicas ou por uma repartição do Governo responsável perante o Congresso, representantes das pessoas amparadas devem tomar parte na administração ou estar ligadas a ela com atribuições consultivas, nas condições determinadas; a legislação nacional pode também prever a participação de representantes dos empregadores e das autoridades públicas.

2. O Membro deve assumir uma responsabilidade geral da boa administração das instituições e serviços que contribuem para a aplicação da presente convenção.

\section{PARTE XIV DISPOSIÇÕES DIVERSAS}

Art. 73 - A presente Convenção não se aplicará:

a) aos eventos ocorridos antes da entrada em vigor da Parte correspondente da convenção para o Membro interessado;

b) às prestações em caso de eventos ocorridos depois da entrada em vigor da Parte correspondente da Convenção para o Membro interessado, na medida em que os direitos a estas prestações provierem de períodos anteriores à data da referida entrada em vigor. 
Art. 74 - A presente Convenção não se deve considerar como implicando na revisão de quaisquer convenções já existentes.

Art. 75 - Quando assim for determinado em uma convenção adotada pela Conferência em data ulterior e que tenha por objeto uma ou várias matérias tratadas na presente, os dispositivos da presente Convenção que forem especificados na nova, cessarão de vigorar para todo Membro que ratificar esta última, desde a sua entrada em vigor para o Membro interessado.

Art. $76-1$. O Membro que ratificar a presente convenção, obriga-se a fornecer no relatório anual sobre a aplicação da convenção que deve apresentar nos termos do artigo 22 da Constituição da Organização Internacional do Trabalho:

a) informações completas sobre a legislação que tornar efetivos os dispositivos da convenção;

b) as provas de que cumpriu as exigências estatísticas formuladas:

i) nos artigos $9^{\circ}$ a, b, c ou d; 15 a, b ou d; 21 a ou c; 27 a, b ou d; 33 a ou b; 41 a, b ou d; 48 a, b ou c; 55 a, b ou d; 61 a, b ou d, quanto ao número de pessoas amparadas;

II) nos artigos 44, 65, 66 ou 67, no que diz respeito ao montante das prestações;

III) na alínea a do parágrafo 2 do artigo 18, no que diz respeito à duração do auxílio-doença;

IV) no parágrafo 2 do artigo 24, no que diz respeito à duração das prestações de desemprego;

v) no parágrafo 2 do artigo 71, no que diz respeito à proporção dos recursos provenientes das contribuições de seguro dos assalariados amparados; as quais, tanto quanto possível, em conformidade com as sugestões do Conselho Administrativo da Repartição Internacional do Trabalho, a fim de se obter maior uniformidade a este respeito.

2. O Membro que ratificar a presente convenção encaminhará ao Diretor-Geral da Repartição Internacional do Trabalho, a intervalos apropriados, de acordo com as decisões do Conselho Administrativo, relatórios sobre a situação de sua legislação e de suas práticas com relação aos dispositivos das Partes de II a X que ainda não tenham sido especificados na ratificação da Convenção por sua parte, nem em notificação ulterior nos termos do artigo 4.

Art. 77 - 1. A presente convenção não se aplica nem aos marinheiros nem aos pescadores marítimos; dispositivos para o amparo dos marinheiros e dos pescadores marítimos foram adotados pela Conferência Internacional do Trabalho na Convenção sobre a Seguridade Social dos Marítimos, 1946, e, na Convenção sobre Aposentadoria dos Marítimos, 1946.

2. Um Membro pode excluir os marinheiros e os pescadores marítimos do número, quer dos assalariados, quer das pessoas da população ativa, quer dos residentes, tomados por base para o cálculo da porcentagem dos assalariados ou dos residentes que são amparados nos termos de 
qualquer uma das Partes de II a X abrangidos pela sua ratificação.

\section{PARTE XVDISPOSIÇÕES FINAIS}

Art. 78 - As ratificações formais da presente convenção serão comunicadas ao Diretor-Geral da Repartição Internacional do Trabalho e por ele registradas.

Art. 79 - 1. A presente convenção será obrigatória somente para os Membros da Organização Internacional do Trabalho cuja ratificação tiver sido registrada pelo Diretor-Geral.

2. Esta convenção entrará em vigor doze meses após terem sido registradas pela Diretor-Geral as ratificações de dois Membros.

3. Em seguida, a Convenção entrará em vigor para cada Membro doze meses após a data em que sua ratificação tiver sido registrada.

Art. 80 - 1. As declarações comunicadas ao Diretor-Geral da Repartição Internacional do Trabalho, nos termos do parágrafo 2 do artigo 35 da Constituição da Organização Internacional do Trabalho, deverão indicar:

a) os territórios para os quais o Membro interessado se compromete a que as disposições da convenção ou alguns de seus capítulos sejam aplicados sem modificações;

b) os territórios para os quais o Membro interessado se compromete no sentido de que os dispositivos da Convenção ou alguma de suas Partes sejam aplicadas com modificações e em que consistem tais modificações;

c) os territórios onde a Convenção não poderá ser aplicada e, nesses casos, as razões por que não pode ser aplicada;

d) os territórios para os quais reserva sua decisão na dependência de um estudo mais pormenorizado da situação dos referidos territórios.

2. Os compromissos mencionados nas alíneas a e b do primeiro parágrafo do presente artigo formarão parte integrante da ratificação e produzirão efeitos idênticos.

3. O Membro poderá renunciar, mediante nova declaração, a todas ou à parte das restrições contidas em sua declaração anterior em virtude das alíneas b, c e d do presente artigo.

4. O Membro poderá, durante os períodos do decurso dos quais a presente Convenção pode ser denunciada, de acordo com o disposto no artigo 82, transmitir ao Diretor-Geral uma nova declaração modificando em qualquer sentido os termos de toda declaração anterior e dando a conhecer a situação em determinados territórios.

Art. 81 - 1. As declarações comunicadas ao Diretor-Geral da Repartição Internacional do Trabalho nos termos dos parágrafos 4 e 5 do artigo 35 da Constituição da Organização 
Internacional do Trabalho devem indicar se os dispositivos do convênio ou Partes aos quais estes dispositivos se referem serão aplicados no território com ou sem modificações; quando a declaração indicar que os dispositivos da convenção ou de certas de suas Partes serão aplicados com a ressalva de modificações, deve especificar em que consistem as referidas modificações.

2. O Membro ou os Membros ou a autoridade internacional interessados poderão renunciar completamente ou em parte, mediante declaração ulterior, ao direito de invocar uma modificação indicada em uma declaração anterior.

3. O Membro ou os Membros ou a autoridade internacional interessados poderão, durante os períodos no decurso dos quais a convenção pode ser denunciada, de acordo com o disposto no artigo 82, transmitir ao Diretor-Geral uma nova declaração que modifique em qualquer sentido os termos de uma declaração anterior e dando a conhecer a situação no que diz respeito à aplicação desta convenção.

Art. $82-1$. O Membro que ratificar a presente convenção, pode, ao término de um período de 10 anos após a data inicial da entrada em vigor, denunciar a mesma ou uma ou várias das Partes de II a X, mediante comunicação ao Diretor-Geral da Repartição Internacional do Trabalho, a que será por este registrada. A denúncia terá efeito somente um ano depois de ter sido registrada.

2. O Membro, que ratificar a presente convenção, e que, no prazo de um ano após a expiração do período de 10 anos mencionado no parágrafo precedente, não fizer uso da faculdade de denúncia prevista no presente artigo, ficará obrigado por um novo período de 10 anos e, em seguida, poderá denunciar o Convênio, ou uma ou várias de suas Partes de II a X, ao término de cada período de 10 anos, nas condições previstas no presente artigo.

Art. 83 - 1. O Diretor-Geral da Repartição Internacional do Trabalho notificará todos os Membros da Organização Internacional do Trabalho do registro de todas as ratificações, declarações e denúncias que lhe forem comunicadas pelos Membros da Organização.

2. Ao notificar os Membros da Organização da segunda ratificação que lhe for comunicada, o Diretor-Geral chamará a atenção dos Membros da Organização sobre a data na qual a presente convenção entrará em vigor.

Art. 84 - O Diretor-Geral da Repartição Internacional do Trabalho transmitirá ao SecretárioGeral das Nações Unidas, para o devido registro nos termos do artigo 102 da Carta das Nações Unidas, informações completas com respeito a todas as ratificações e declarações e todos os atos de denúncia que houver registrado, de acordo com os artigos precedentes.

Art. 85 - Toda vez que julgar necessário, o Conselho Administrativo da Repartição Internacional do Trabalho apresentará à Conferência Geral um relatório sobre a aplicação da presente convenção e examinará a conveniência de inscrever na ordem do dia da Conferência a questão de sua revisão, total ou parcial. 
Art. 86 - 1. No caso de a Conferência adotar uma nova convenção, que importe na revisão total ou parcial, da presente Convenção e, a menos que a nova convenção disponha de modo diverso:

a) a ratificação por um Membro da nova convenção que importar na revisão, resultará, de pleno direito, não obstante o artigo 82 acima na imediata denúncia desta última com a ressalva de que a nova convenção tenha entrado em vigor;

b) a partir da data da entrada em vigor da nova convenção que importar na revisão, a presente convenção cessará de estar aberta à ratificação por parte dos Membros.

2. Em qualquer caso, a presente convenção continuará em vigor, em sua forma e teor, para os Membros que a hajam ratificado e que não ratificarem a convenção que importar em sua revisão.

Art. 87 - As versões francesa e inglesa do texto da presente Convenção fazem igualmente fé.

ANEXO Classificação Internacional Padrão, por Indústria, de todos os Ramos da Atividade Econômica Nomenclatura dos ramos e das classes

Ramo 0. Agricultura, silvicultura, caça e pesca:

01. Agricultura e criação.

02. Silvicultura e exploração florestal.

03. Caça, caça por meio de armadilhas e repovoamento das tapadas.

04. Pesca.

Ramo 1. Indústrias de extração:

11. Extração de carvão.

12. Extração de minérios.

13. Petróleo bruto e gás natural.

14. Extração de pedra para construção, barro e saibro.

15. Extração de minérios não metalíferos, não classificados em outro lugar.

Ramo 2-3. Indústrias manufatureiras:

20. Indústrias de gêneros alimentícios (com exceção de bebidas)

21. Indústrias de bebidas.

22. Indústrias de fumo.

23. Indústrias têxteis.

24. Fabricação de calçados, artigos de vestuário e outros artigos feitos com matérias têxteis.

25. Indústrias de madeira e cortiça (com exceção da indústria de móveis).

26. Indústrias de móveis e de mobiliário.

27. Indústrias de papel e fabricação de artefatos de papel.

28. Tipografias, publicações e indústrias congêneres.

29. Indústrias de couro e de artefatos de couro (com exceção de calçados).

30. Indústrias de borracha.

31. Indústrias químicas e de produtos químicos. 
32. Indústrias dos subprodutos do petróleo e do carvão.

33. Indústrias de produtos minerais não metálicos (com exceção dos subprodutos do petróleo e do carvão).

34. Indústrias metalúrgicas de base.

35. Fabricação de artefatos de metal (com exceção de máquinas e de material de transporte).

36. Construção de máquinas (com exceção de máquinas elétricas).

37. Construção de máquinas, aparelhos e materiais elétricos.

38. Construção de material de transporte.

39. Indústrias manufatureiras diversas.

Ramo 4. Construção:

40. Construção.

Ramo 5. Eletricidade, gás, água e serviços de saneamento:

51. Eletricidade, gás e vapor.

52. Serviços de águas e serviços de saneamento.

Ramo 6. Comércio, Bancos, Companhias de Seguro, Empresas Imobiliárias:

61. Comércio por atacado e a varejo.

62. Bancos e outros estabelecimentos financeiros.

63. Seguros.

64. Empresas imobiliárias.

Ramo 7. Transportes, entrepostos e comunicações:

71. Transportes.

72. Entrepostos e armazéns.

73. Comunicações.

Ramo 8. Serviços:

81. Serviços do Governo.

82. Serviços prestados ao público e às empresas.

83. Serviços de recreação.

84. Serviços pessoais.

Ramo 9. Atividades mal definidas:

Atividades mal definidas. 
V) Acordo de Previdência Social entre o Brasil e o Japão ${ }^{\mathbf{1 8 5}}$

\section{$\underline{\text { Decreto }^{\circ} 7.702 / 12}$}

A PRESIDENTA DA REPÚBLICA, no uso da atribuição que lhe confere o art. 84, inciso IV, da Constituição, e

Considerando que a República Federativa do Brasil e o Japão firmaram, em Tóquio, em 29 de julho de 2010, o Acordo de Previdência Social;

Considerando que o Congresso Nacional aprovou o Acordo, por meio do Decreto Legislativo $\mathrm{n}^{\mathrm{o}}$ 298, de 30 de setembro de 2011;

Considerando que o Acordo entrará em vigor para a República Federativa do Brasil, no plano jurídico externo, em $1^{\circ}$ de março de 2012, nos termos de seu Artigo 27;

\section{DECRETA:}

Art. $1^{\circ}$ O Acordo de Previdência Social firmado entre a República Federativa do Brasil e o Japão, firmado em Tóquio, em 29 de julho de 2010, apenso por cópia a este Decreto, será executado e cumprido tão inteiramente como nele se contém.

Art. $2^{\underline{0}}$ São sujeitos à aprovação do Congresso Nacional quaisquer atos que possam resultar em revisão do referido Acordo, assim como quaisquer ajustes complementares que, nos termos do inciso I do caput do art. 49 da Constituição, acarretem encargos ou compromissos gravosos ao patrimônio nacional.

Art. $3^{-}$Este Decreto entra em vigor na data de sua publicação.

Brasília, 15 de março de 2012; $191^{\circ}$ da Independência e 124ํำ da República.

DILMA ROUSSEFF

Antonio de Aguiar Patriota

Garibaldi Alves Filho

Este texto não substitui o publicado no DOU de 16.3.2012

185 Fontes: $\quad$ http://www.planalto.gov.br/ccivil_03/_Ato2011-2014/2012/Decreto/D7702.htm e http://www.previdencia.gov.br/a-previdencia/assuntos-internacionais/assuntos-internacionais-acordosinternacionais-portugues/ 


\section{ACORDO DE PREVIDÊNCIA SOCIAL ENTRE A REPÚBLICA FEDERATIVA DO BRASIL E O JAPÃO}

A República Federativa do Brasil e o Japão,

Desejosos de regular suas relações mútuas na área de Previdência Social,

Acordaram o seguinte:

\section{Parte I}

Disposições Gerais

\section{Artigo 1}

Definições

1. Para os fins deste Acordo:

a) os termos "um Estado Contratante" e "o outro Estado Contratante" significam a República Federativa do Brasil ou o Japão, conforme requerido pelo contexto;

b) o termo "Brasil" significa a República Federativa do Brasil;

c) o termo "nacional" significa, em relação ao Brasil, um nacional brasileiro de acordo com a Constituição Federal e leis da República Federativa do Brasil, em relação ao Japão, um nacional japonês dentro do significado da lei sobre a nacionalidade do Japão;

d) o termo "legislação" significa, em relação ao Brasil, as leis e regulamentos referentes aos benefícios especificados no parágrafo 2 do Artigo 2, em relação ao Japão, as leis e regulamentos do Japão referentes aos sistemas previdenciários do Japão especificados no parágrafo 1 do Artigo 2;

e) o termo "autoridade competente" significa, em relação ao Brasil, o Ministério responsável pela aplicação da legislação do Brasil referida no parágrafo 1, alínea (d), deste Artigo, em relação ao Japão, qualquer das organizações governamentais competentes no que se refere aos sistemas previdenciários japoneses especificados no parágrafo 1 do Artigo 2;

f) o termo "instituição competente" significa, em relação ao Brasil, o Instituto Nacional do Seguro Social, em relação ao Japão, qualquer das instituições de seguro, ou qualquer associação destas, responsáveis pela implementação dos sistemas previdenciários japoneses especificados no parágrafo 1 do Artigo 2;

g) o termo "período de cobertura" significa, em relação ao Brasil, um período de contribuições e quaisquer outros períodos levados em consideração para o estabelecimento de 
direito a benefícios sob a legislação do Brasil, em relação ao Japão, um período de contribuições sob a legislação do Japão referente aos sistemas previdenciários japoneses especificados no parágrafo 1, alíneas (a) a (e) do Artigo 2 e quaisquer outros períodos considerados sob aquela legislação para estabelecer o direito a benefícios, contudo, um período que será levado em consideração para o propósito de estabelecer direito a benefícios sob aquela legislação, sob a égide de outros acordos de previdência social comparáveis a este Acordo, não deve ser incluído;

h) o termo "benefício" significa uma aposentadoria, pensão ou qualquer outro benefício monetário sob a legislação de um Estado Contratante.

2.Para os propósitos deste Acordo, qualquer termo não definido neste Acordo terá o significado que lhe é atribuído pela legislação aplicável.

\section{Artigo 2}

\section{Campo de Aplicação Material}

Este Acordo será aplicado,

1. no que se refere ao Japão, aos seguintes sistemas previdenciários japoneses:

a) a Pensão Nacional (excetuado o Fundo de Pensão Nacional);

b) o Seguro de Pensão dos Empregados (excetuado o Fundo de Pensão dos Empregados);

c) a Pensão Mútua para Funcionários Públicos Nacionais;

d) a Pensão Mútua para Funcionários Públicos Locais e Pessoal de Status Similar (excetuado o sistema de previdência para membros de assembleias locais); e

e) a Pensão Mútua para Pessoal de Escolas Privadas;

(os sistemas previdenciários japoneses especificados nas alíneas (b) a (e) serão, doravante, designados como os "sistemas previdenciários japoneses para empregados"), contudo, para os propósitos deste Acordo, a Pensão Nacional não incluirá o Benefício Assistencial por Idade ou quaisquer outras pensões concedidas sob fundamento transitório ou complementar com fins assistenciais e que são pagáveis total ou principalmente com os recursos do orçamento nacional; e

2. no que se refere ao Brasil:

a) às aposentadorias por idade e por invalidez e pensão por morte sob o Regime Geral de Previdência Social; e 
b) às aposentadorias por idade e por invalidez e pensão por morte sob o regime dos militares e o regime próprio dos servidores públicos.

\section{Artigo 3}

\section{Campo de Aplicação Pessoal}

Este Acordo será aplicado a uma pessoa que esteja ou que tenha estado sujeita à legislação de um Estado Contratante, bem como aos dependentes. Para os propósitos deste Artigo, o termo "dependentes" significa, no que se refere ao Japão, membros da família ou sobreviventes que derivam direitos de uma pessoa que está ou esteve sujeita à legislação do Japão e, no que se refere ao Brasil, dependentes conforme definido sob a legislação do Brasil.

\section{Artigo 4}

Igualdade de Tratamento

Salvo disposição contrária neste Acordo, as pessoas especificadas no Artigo 3 e que habitualmente residam no território de um Estado Contratante receberão tratamento igual dispensado aos nacionais daquele Estado Contratante na aplicação da legislação daquele Estado Contratante.

\section{Artigo 5}

\section{Pagamento de Benefícios no Exterior}

1. Salvo disposição contrária neste Acordo, qualquer disposição da legislação de um Estado Contratante que restrinja o direito a ou o pagamento de benefícios somente devido a que a pessoa habitualmente resida fora do território deste Estado Contratante não será aplicável a pessoas que residam habitualmente no território do outro Estado Contratante.

2. Benefícios sob a legislação de um Estado Contratante serão pagos a nacionais do outro Estado Contratante que habitualmente residam no território de um terceiro Estado sob as mesmas condições como se fossem nacionais do primeiro Estado Contratante.

3. Pagamentos de benefícios sob este Acordo a beneficiários que residam no território do outro Estado Contratante serão efetuados diretamente em moeda livremente conversível. No caso da introdução de medidas restritivas do câmbio ou remessa de divisas por qualquer Estado Contratante, os Governos de ambos os Estados Contratantes consultar-seão imediatamente sobre as medidas necessárias para assegurar os pagamentos de benefícios por qualquer Estado Contratante sob este Acordo.

\section{Parte II}

Disposições Relativas à Legislação Aplicável 


\title{
Artigo 6
}

\author{
Disposições Gerais
}

Salvo disposição contrária neste Acordo, uma pessoa que trabalhe como empregado ou por conta própria no território de um Estado Contratante estará sujeita, no que diz respeito a este emprego ou atividade por conta própria, à legislação exclusivamente deste Estado Contratante.

\section{Artigo 7}

\section{Disposições Especiais}

1. Se uma pessoa empregada por um empregador que tenha uma empresa localizada no território de um dos Estados Contratantes for deslocada por esse empregador, seja daquele território ou do território de um terceiro Estado, para trabalhar no território do outro Estado Contratante, esse empregado estará sujeito à legislação apenas do primeiro Estado Contratante como se estivesse empregado no território do primeiro Estado Contratante, desde que este empregado esteja coberto sob a legislação daquele Estado Contratante e que não se preveja que tal período de deslocamento ultrapasse cinco (5) anos.

2. Se o deslocamento referido no parágrafo 1 deste Artigo continuar além de cinco (5) anos, as autoridades competentes ou instituições competentes de ambos os Estados Contratantes poderão acordar, em circunstâncias especiais, que o empregado permaneça sujeito apenas à legislação do primeiro Estado Contratante por um período não superior a três (3) anos.

3. Uma pessoa que tenha estado sujeita às disposições do parágrafo 1 deste Artigo não estará sujeita novamente àquelas disposições, salvo se decorrido um (1) ano desde o término do deslocamento anterior.

4. Se uma pessoa que habitualmente trabalha por conta própria no território de um Estado Contratante trabalhar temporariamente em atividade por conta própria apenas no território do outro Estado Contratante, aquela pessoa estará sujeita apenas à legislação do primeiro Estado Contratante como se aquela pessoa estivesse trabalhando no território do primeiro Estado Contratante, desde que aquela pessoa esteja coberta sob a legislação daquele Estado Contratante e que não se preveja que o período da atividade por conta própria no território do outro Estado Contratante ultrapasse cinco (5) anos.

5. Se a atividade por conta própria no território do outro Estado Contratante referida no parágrafo 4 deste Artigo continuar além de cinco (5) anos, as autoridades competentes ou instituições competentes de ambos osEstados Contratantes poderão acordar, em circunstâncias especiais, que a pessoa por conta própria permaneça sujeita apenas à legislação do primeiro Estado Contratante por um período não superior a três (3) anos. 
6. Uma pessoa que tenha estado sujeita às disposições do parágrafo 4 deste Artigo não estará sujeita novamente àquelas disposições, salvo se decorrido um (1) ano desde o término da atividade por conta própria anterior.

\section{Artigo 8}

Empregados a Bordo de um Navio

Se uma pessoa trabalhar como empregado a bordo de um navio que ostente o pavilhão de um Estado Contratante e que estaria sujeita à legislação de ambos os Estados Contratantes se não houvesse este Acordo, aquela pessoa estará sujeita apenas à legislação daquele Estado Contratante. Não obstante o acima mencionado, aquela pessoa estará sujeita somente à legislação do outro Estado Contratante se aquela pessoa for empregada por um empregador com sede no território do outro Estado Contratante.

\section{Artigo 9}

Membros de Missões Diplomáticas, Membros de Postos

\section{Consulares e Servidores Públicos}

1. Este Acordo não afetará as disposições da Convenção de Viena sobre Relações Diplomáticas de 18 de Abril de 1961, ou da Convenção de Viena sobre as Relações Consulares de 24 de Abril de 1963.

2. Observado o parágrafo 1 deste Artigo, quando qualquer servidor público de um Estado Contratante ou qualquer pessoa assim tratada na legislação daquele Estado Contratante for deslocado para trabalhar no território do outro Estado Contratante, aquela pessoa estará sujeita apenas à legislação do primeiro Estado Contratante como se aquela pessoa estivesse trabalhando no território do primeiro Estado Contratante.

\section{Artigo 10}

\section{Exceções aos Artigos 6 a 9}

A pedido de um empregado e um empregador ou de uma pessoa por conta própria, as autoridades competentes ou as instituições competentes de ambos os Estados Contratantes podem concordar em conceder uma exceção aos Artigos 6 a 9 para atender ao interesse de determinadas pessoas ou categorias de pessoas, desde que tais pessoas ou categorias de pessoas estejam sujeitas à legislação de um dos Estados Contratantes.

\section{Artigo 11}

Cônjuge e Filhos 
Quando uma pessoa trabalhar no território do Japão e estiver sujeita somente à legislação do Brasil, de acordo com o Artigo 7, o parágrafo 2 do Artigo 9 ou o Artigo 10, o cônjuge ou filhos que venham com esta pessoa estarão isentos da legislação do Japão no que se refere ao sistema previdenciário japonês especificado no parágrafo 1, alínea (a), do Artigo 2, desde que os requerimentos especificados na legislação do Japão no que se refere à implementação dos acordos de previdência social estejam cumpridos. Contudo, quando esses cônjuge ou filhos assim o requererem, o precedente não será aplicado.

\section{Artigo 12}

\section{Cobertura Compulsória}

Os Artigos 6 a 8, o parágrafo 2 do Artigo 9 e o Artigo 11 serão aplicados apenas à cobertura compulsória sob a legislação de cada Estado Contratante.

\section{Parte III}

Disposições sobre Benefícios

\section{Capítulo 1}

Disposições relativas a Benefícios Japoneses

\section{Artigo 13}

\section{Totalização}

1. Quando uma pessoa não possuir períodos de cobertura suficientes para atender aos requisitos para o direito a benefícios japoneses, a instituição competente do Japão levará em consideração, para fins de estabelecer direitos a esses benefícios sob este Artigo, os períodos de cobertura sob a legislação do Brasil desde que não coincidam com os períodos de cobertura sob a legislação do Japão. Contudo, o acima mencionado não se aplicará aos benefícios adicionais para determinadas ocupações sob as previdências mútuas e os benefícios de pecúlio equivalentes à restituição de contribuições.

2. Ao aplicar o parágrafo 1 deste Artigo, os períodos de cobertura sob a legislação do Brasil serão levados em consideração como períodos de cobertura sob os sistemas previdenciários japoneses para empregados e como os períodos de cobertura correspondentes sob a Pensão Nacional. 


\section{Artigo 14}

Disposições Especiais relativas a Benefícios por Invalidez e Pensões por Morte

1. Quando a legislação do Japão exigir para o estabelecimento do direito a benefícios por invalidez ou pensões por morte (excetuados os pagamentos de pecúlio correspondentes às restituições de contribuições) que a data da primeira perícia médica ou da morte esteja dentro de determinados períodos de cobertura, esta exigência será considerada cumprida para o propósito de estabelecer direito àqueles benefícios se tal data estiver compreendida em períodos de cobertura sob a legislação do Brasil. Contudo, se o direito a benefícios por invalidez ou pensão por morte (excetuados os pagamentos de pecúlio correspondentes às restituições de contribuições) sob a Pensão Nacional for estabelecido sem a aplicação deste Artigo, este Artigo não será aplicado para o propósito de estabelecer direito a benefícios por invalidez ou a pensão por morte (excetuados os pagamentos de pecúlio correspondentesàs restituições de contribuições) com base no mesmo evento segurado sob os sistemas previdenciários japoneses para empregados.

2. Ao aplicar o parágrafo 1 deste Artigo, no que se refere a uma pessoa que possua períodos de cobertura sob dois ou mais sistemas previdenciários japoneses para empregados, a exigência referida naquele parágrafo será considerada cumprida em um daqueles sistemas previdenciários de acordo com a legislação do Japão.

3. O parágrafo 1 do Artigo 5 não afetará as disposições da legislação do Japão que requerem que uma pessoa, com idade igual ou superior a 60, mas abaixo de 65 , resida habitualmente no território do Japão, na data da primeira perícia médica ou da morte, para aquisição do direito à Aposentadoria Básica por Invalidez ou à Pensão Básica por Morte.

\section{Artigo 15}

\section{Cálculo do Valor dos Benefícios}

1. Quando o direito a um benefício japonês for estabelecido em virtude do parágrafo 1 do Artigo 13 ou do parágrafo 1 do Artigo 14, a instituição competente do Japão calculará o valor daquele benefício em conformidade com a legislação do Japão, sujeito aos parágrafos 2 a 5 deste Artigo.

2. Com referência à Aposentadoria Básica por Invalidez e outros benefícios, cujo valor é um montante fixo independentemente dos períodos de cobertura, caso as exigências para receber tais benefícios sejam cumpridas em virtude do parágrafo 1 do Artigo 13 ou do parágrafo 1 do Artigo 14, o valor a ser concedido será calculado de acordo com a proporção da soma dos tempos de contribuição e dos períodos dispensados de contribuição sob o sistema previdenciário a partir do qual tais benefícios serão pagos frente ao período teórico de cobertura, mencionado no parágrafo 4 deste Artigo. 
3.Com relação a benefícios por invalidez e pensões por morte sob os sistemas previdenciários japoneses para empregados, conquanto o valor de tais benefícios a serem concedidos for calculado com base em um período especificado determinado pela legislação do Japão, quando os períodos de cobertura sob tais sistemas forem inferiores a este período especificado, se as exigências para receber tais benefícios forem cumpridas em virtude do parágrafo 1 do Artigo 13 ou do parágrafo 1 do Artigo 14, o valor a ser concedido será calculado de acordo com a proporção dos períodos de cobertura sob os sistemas previdenciários japoneses para empregados frente ao período teórico de cobertura, mencionado no parágrafo 4 deste Artigo. Contudo, quando o período teórico de cobertura exceder aquele período especificado, o período teórico de cobertura será considerado como igual ao período especificado.

4. Para os propósitos dos parágrafos 2 e 3 deste Artigo, "período teórico de cobertura" significa a soma dos seguintes períodos (observado que ele não poderá incluir o período após o mês no qual ocorra o dia de reconhecimento da invalidez ou o período que inicia com o mês em que ocorre o dia subsequente ao dia da morte):

a) o período desde o mês no qual é completada a idade de 20 anos até o mês precedente ao mês no qual é completada a idade de 60 anos, salvo o período anterior a $1^{\circ}$ de abril de 1961 ;

b) períodos de contribuição sob a legislação do Japão que não coincidam com o período mencionado na alínea (a) deste parágrafo; e

c) períodos de cobertura sob a legislação do Brasil que não coincidam com períodos mencionados na alínea (b) deste parágrafo, no caso de que o mês no qual ocorre o dia do reconhecimento da invalidez ou o mês anterior ao mês no qual ocorre o dia subsequente à morte estejam antes do período mencionado na alínea (a) deste parágrafo.

5. Com relação ao cálculo do valor dos benefícios sob os sistemas previdenciários japoneses para empregados sob os parágrafos 2 e 3 deste Artigo, caso a pessoa que tenha direito aos benefícios possua períodos de cobertura sob dois ou mais tais sistemas previdenciários, os períodos de contribuição sob o sistema previdenciário do qual tais benefícios serão pagos mencionados no parágrafo 2 deste Artigo ou os períodos de cobertura sob os sistemas previdenciários japoneses para empregados mencionados no parágrafo 3 deste Artigo serão a soma dos períodos de cobertura sob todos estes sistemas previdenciários. Contudo, quando a soma dos períodos de cobertura igualar ou exceder o período especificado determinado pela legislação do Japão prevista no parágrafo 3 deste Artigo, o método de cálculo estipulado no parágrafo 3 deste Artigo e neste parágrafo não será aplicado.

6. Com relação ao Benefício Adicional para Cônjuges que está incluído na Aposentadoria por Idade dos Empregados e quaisquer outros benefícios que possam ser concedidos como um valor fixo em casos em que os períodos de cobertura sob os sistemas previdenciários japoneses para empregados se igualem a ou excedam os períodos especificados determinados pela legislação do Japão, caso as exigências para receber tais 
benefícios sejam cumpridas em virtude do parágrafo 1 do Artigo 13, o valor a ser concedido será calculado de acordo com a proporção destes períodos de cobertura sob os sistemas previdenciários japoneses para empregados sob os quais tais benefícios serão pagos frente àquele período especificado.

\section{Artigo 16}

\section{Exceção ao Artigo 4}

O Artigo 4 não afetará as disposições sobre períodos complementares para nacionais japoneses fundamentados na residência habitual fora do território do Japão sob a legislação do Japão.

\section{Capítulo 2}

Disposições relativas a Benefícios Brasileiros

\section{Artigo 17}

\section{Totalização e Regras de Cálculo}

1. Quando uma pessoa não for elegível a um benefício sob a legislação do Brasil por não ter acumulado períodos de cobertura suficientes de acordo com aquela legislação, os períodos de cobertura sob a legislação do Japão serão também considerados para determinar a elegibilidade daquela pessoa. Para aplicar o acima mencionado, a instituição competente do Brasil deverá:

a) calcular o valor teórico do benefício que seria pago se todos os períodos de cobertura houvessem sido completados sob a legislação do Brasil;

b) sobre a base daquele valor teórico, calcular, então, o valor real do benefício a ser pago de acordo com a razão entre a duração dos períodos de cobertura completados sob a legislação do Brasil e a duração total dos períodos de cobertura sob a legislação de ambos os Estados Contratantes. Contudo, se esta duração total exceder o período mínimo necessário para estabelecer o direito ao benefício sob a legislação do Brasil, a duração total será considerada igual ao período mínimo.

2. O valor teórico do benefício mencionado no parágrafo 1, alínea (a), deste Artigo não será, sob nenhuma circunstância, inferior ao valor mínimo garantido pela legislação do Brasil.

3. Caso uma pessoa seja elegível a um benefício sob a legislação do Brasil sem a aplicação do parágrafo 1 deste Artigo, a instituição competente do Brasil determinará o valor do benefício a ser pago com base exclusivamente nos períodos de cobertura completados por esta pessoa sob a legislação do Brasil. 


\section{Parte IV}

Disposições Diversas

Artigo 18

Colaboração Administrativa

1. As autoridades competentes de ambos os Estados Contratantes deverão:

a) concordar quanto às medidas administrativas necessárias à implementação deste Acordo;

b) designar organismos de ligação para a implementação deste Acordo; e

c) comunicar reciprocamente, assim que possível, qualquer informação sobre mudanças em suas respectivas legislações que possam influenciar a implementação deste Acordo.

2. As autoridades competentes e instituições competentes de ambos os Estados Contratantes, no âmbito de suas respectivas competências, proverão qualquer auxílio necessário à implementação deste Acordo. Esta assistência será gratuita.

\section{Artigo 19}

Taxas ou Emolumentos e Legalização

1. Quando a legislação e outras leis e regulamentos pertinentes de um Estado Contratante contiverem disposições de uma isenção ou redução de taxas administrativas ou emolumentos consulares para documentos a serem submetidos sob a legislação daquele Estado Contratante, estas disposições também serão aplicadas a documentos a serem submetidos na aplicação deste Acordo e da legislação do outro Estado Contratante.

2. Documentos apresentados para os propósitos deste Acordo e da legislação de um Estado Contratante não necessitarão de legalização ou qualquer outra formalidade similar por autoridades diplomáticas ou consulares.

\section{Artigo 20}

\section{Comunicação}

1. Ao implementar este Acordo, as autoridades competentes e as instituições competentes de ambos os Estados Contratantes podem comunicar-se diretamente entre si em língua portuguesa ou japonesa e com qualquer pessoa envolvida, onde quer que esta pessoa possa residir. 
2. Ao implementar este Acordo, as autoridades competentes e as instituições competentes de um Estado Contratante não podem rejeitar requerimentos ou quaisquer outros documentos pelo motivo de que eles estejam redigidos na língua do outro Estado Contratante.

\section{Artigo 21}

Transmissão e Confidencialidade de Informações

1. As autoridades competentes ou instituições competentes de um Estado Contratante transmitirão, de acordo com suas leis e regulamentos, às autoridades competentes ou instituições competentes do outro Estado Contratante informações sobre uma pessoa coletadas sob a legislação daquele Estado Contratante, na medida em que aquela informação seja necessária à implementação deste Acordo. Salvo disposição contrária nas leis e regulamentos daquele outro Estado Contratante, aquela informação será usada exclusivamente para o propósito de implementar este Acordo.

2. As autoridades competentes ou instituições competentes de um Estado Contratante podem, a pedido das autoridades competentes ou instituições competentes do outro Estado Contratante, transmitir, de acordo com a legislação e outras leis e regulamentações pertinentes daquele Estado Contratante, informações sobre uma pessoa diversas daquela informação referida no parágrafo 1 deste Artigo, coletadas sob a legislação daquele Estado Contratante, às autoridades competentes ou instituições competentes daquele outro Estado Contratante, desde que elas sejam necessárias para a implementação da legislação daquele outro Estado Contratante. Salvo disposição contrária nas leis e regulamentos daquele outro Estado Contratante, aquela informação será usada exclusivamente para o propósito de implementar a legislação daquele outro Estado Contratante.

3. As informações mencionadas nos parágrafos 1 e 2 deste Artigo recebidas por um Estado Contratante serão governadas pelas leis e regulamentos daquele Estado Contratante para a proteção da confidencialidade de dados pessoais.

\section{Artigo 22}

Apresentação de Requerimentos,

Recursos e Declarações

1. Quando um requerimento de benefícios por escrito, um recurso ou qualquer outra declaração sob a legislação de um Estado Contratante for submetida a uma autoridade competente ou instituição competente do outro Estado Contratante que é competente para receber requerimentos, recursos ou declarações similares sob a legislação daquele outro Estado Contratante, aquele requerimento de benefícios, recurso ou declaração será considerada como submetida na mesma data à autoridade competente ou instituição competente do primeiro Estado Contratante e será tratada de acordo com o procedimento e a legislação do primeiro Estado Contratante. 
2. A autoridade competente ou instituição competente de um Estado Contratante enviará o requerimento de benefícios, recurso ou qualquer outra declaração submetida de acordo com o parágrafo 1 deste Artigo à autoridade competente ou instituição competente do outro Estado Contratante sem demora.

\section{Artigo 23}

Resolução de Desacordos

Qualquer desacordo quanto à interpretação ou aplicação deste Acordo será resolvido mediante consultas entre os Estados Contratantes.

\section{Artigo 24}

\section{Comissão Mista}

Os Estados Contratantes poderão estabelecer uma Comissão Mista composta por representantes das autoridades competentes e instituições competentes de ambos os Estados Contratantes. Esta Comissão Mista será responsável por monitorar a aplicação deste Acordo. Esta Comissão Mista reunir-se-á quando necessário, seja no Brasil ou no Japão, a pedido de qualquer Estado Contratante.

\section{Artigo 25}

Títulos

Os títulos de Partes, Capítulos e Artigos deste Acordo são inseridos somente para a conveniência de referência e não afetarão a interpretação deste Acordo.

\section{Parte V}

Disposições Finais e Transitórias

\section{Artigo 26}

Eventos e Decisões Anteriores à

\section{Entrada em Vigor}

1. Este Acordo não conferirá nenhum direito a benefícios por qualquer período anterior à sua entrada em vigor.

2. Na implementação deste Acordo serão também levados em consideração períodos de cobertura completados antes de sua entrada em vigor bem como outros eventos legalmente pertinentes ocorridos antes da sua entrada em vigor. 
3. Ao aplicar os parágrafos 1 ou 4 do Artigo 7, no caso de uma pessoa que esteja trabalhando no território de um Estado Contratante antes da entrada em vigor deste Acordo, os períodos de deslocamento ou atividade por conta própria mencionados nos parágrafos 1 ou 4 do Artigo 7 serão considerados como tendo início na data de entrada em vigor deste Acordo.

4. Decisões tomadas antes da entrada em vigor deste Acordo não afetarão quaisquer direitos constituídos em virtude deste Acordo.

5. A aplicação deste Acordo não resultará, para um beneficiário, em qualquer redução do valor de benefícios para o qual o direito havia sido estabelecido antes da entrada em vigor deste Acordo.

6. Sujeito ao parágrafo 1 deste Artigo, caso um requerimento de um benefício de acordo com disposições deste Acordo seja apresentado dentro de dois anos após a entrada em vigor deste Acordo, o benefício correspondente poderá ser pago a partir do momento em que as condições necessárias forem satisfeitas. Se o requerimento for feito após o prazo de dois anos após a data da entrada em vigor deste Acordo, os efeitos desse requerimento estarão sujeitos à legislação do Estado Contratante pertinente.

\section{Artigo 27}

\section{Entrada em Vigor}

Este Acordo entrará em vigor no primeiro dia do terceiro mês após o mês no qual os Estados Contratantes tenham completado a troca de Notas diplomáticas informando reciprocamente que suas respectivas exigências constitucionais necessárias à entrada em vigor deste Acordo foram cumpridas.

\section{Artigo 28}

\section{Vigência e Denúncia}

1. Este Acordo permanecerá em vigor por um período indefinido. Qualquer dos Estados Contratantes pode denunciar este Acordo junto ao outro Estado Contratante, via canal diplomático, mediante aviso escrito de denúncia deste Acordo. Neste caso, o Acordo permanecerá em vigor até o último dia do décimo-segundo mês seguinte ao mês no qual a denúncia foi apresentada.

2. Em caso de denúncia deste Acordo conforme parágrafo 1 deste Artigo, serão preservados os direitos quanto à elegibilidade ou ao pagamento de benefícios adquiridos sob este Acordo.

Em testemunho do que, os abaixo assinados, devidamente autorizados por seus respectivos Governos, firmaram este Acordo. 
Feito em Tóquio, em 29 de julho de 2010, em duplicata, em português, japonês e inglês. Em caso de qualquer divergência de interpretação, o texto em inglês prevalecerá.

\author{
PELA REPÚBLICA PELO JAPÃO \\ FEDERATIVA \\ DO BRASIL
Carlos Eduardo Gabas Katsuya Okada
Ministro da Ministro dos
Previdência Social Negócios
Estrangeiros

